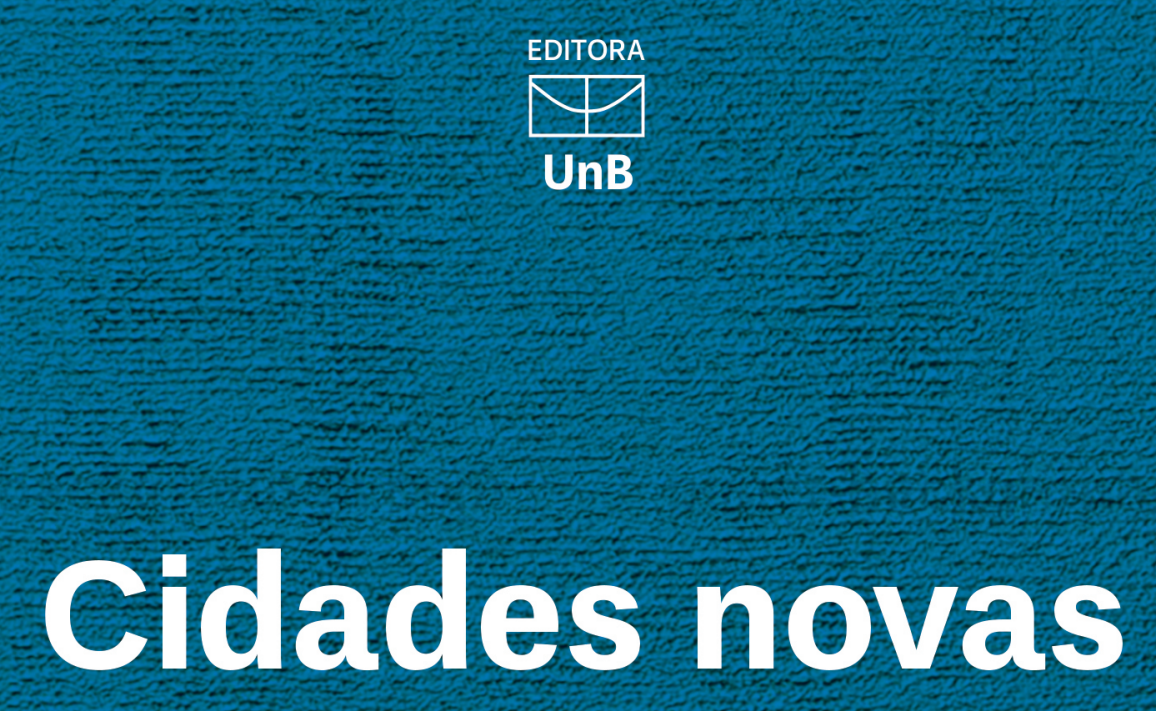

Ricardo Trevisan 


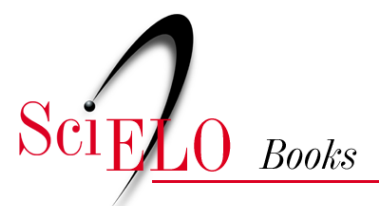

\title{
Cidades novas
}

\author{
Ricardo Trevisan
}

TREVISA, R. Cidades novas [online]. Brasília: Editora UnB, 2020, 295 p. Pesquisa, inovação \& ousadia series. ISBN: 978-65-5846-158-6. https://doi.org/10.7476/9786558461586.

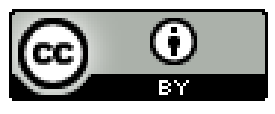

All the contents of this work, except where otherwise noted, is licensed under a $\underline{\text { Creative }}$ Commons Attribution 4.0 International license.

Todo o conteúdo deste trabalho, exceto quando houver ressalva, é publicado sob a licença Creative Commons Atribição 4.0.

Todo el contenido de esta obra, excepto donde se indique lo contrario, está bajo licencia de la licencia Creative Commons Reconocimento 4.0. 
Cidades novas 


\section{$\Psi$ Universidade de Brasília}

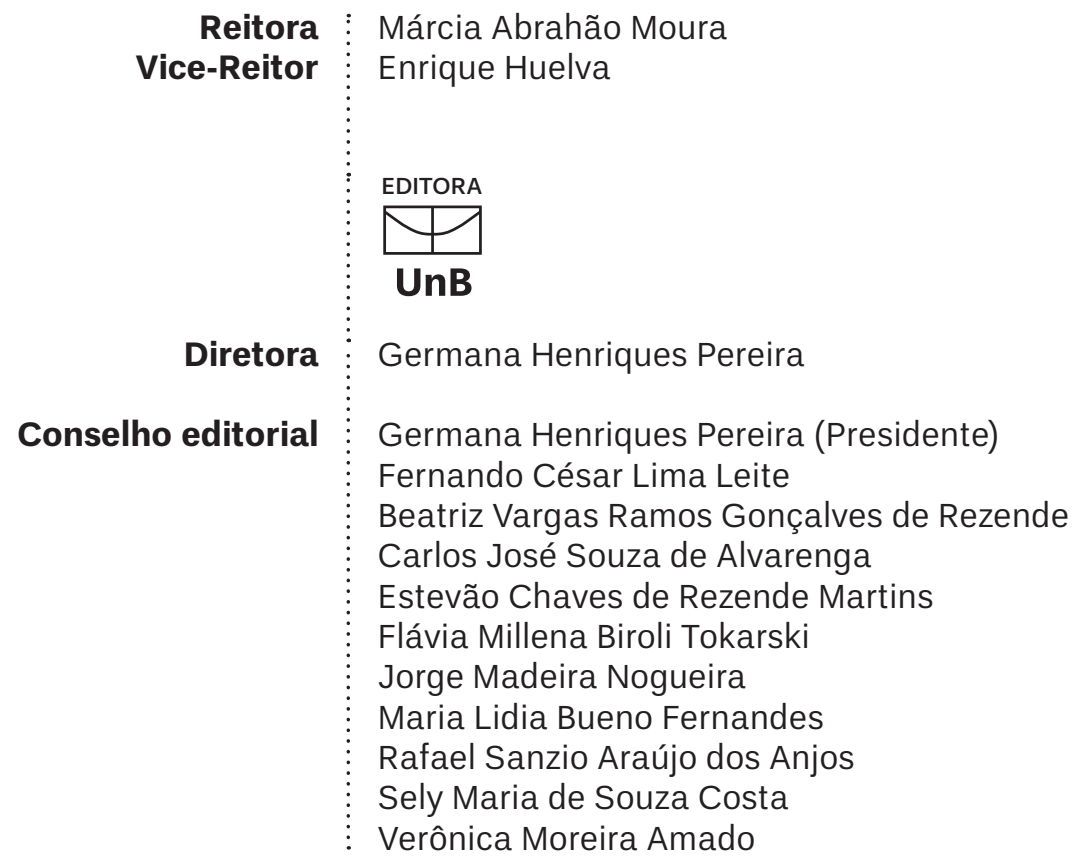




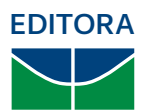

UnB

\title{
Cidades novas
}

\author{
Ricardo Trevisan
}

Ilustrações: Arielle Cristina Martins dos Reis

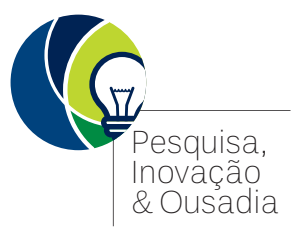




\section{Coordenação de produção editorial Preparação e revisão Diagramação}

\section{Equipe editorial}

Luciana Lins Camello Galvão

Talita Guimarães Sales Ribeiro

Cláudia Dias

(c) 2018 Editora Universidade de Brasília

Direitos exclusivos para esta edição:

Editora Universidade de Brasília

SCS, quadra 2, bloco C, $\mathrm{n}^{\circ} 78$, edifício OK, $2^{\circ}$ andar, CEP 70302-907, Brasília, DF

Telefone: (61) 3035-4200

Site: www.editora.unb.br

E-mail: contatoeditora@unb.br

Todos os direitos reservados. Nenhuma parte desta publicação poderá ser armazenada ou reproduzida por qualquer meio sem a autorização por escrito da Editora. Esta obra foi publicada com recursos provenientes do Edital DPI/DPG n²/2017.

Ficha catalográfica elaborada pela Biblioteca Central da Universidade de Brasília

T814 Trevisan, Ricardo.

Cidades novas / Ricardo Trevisan. - Brasília : Editora

Universidade de Brasília, 2020.

296 p. ; 23 cm. - (Pesquisa, inovação \& ousadia).

ISBN 978-65-5846-041-1

1. Urbanismo. 2. História do urbanismo. 3. Planejamento urbano. I. Título. II. Série.

CDU 711.4 


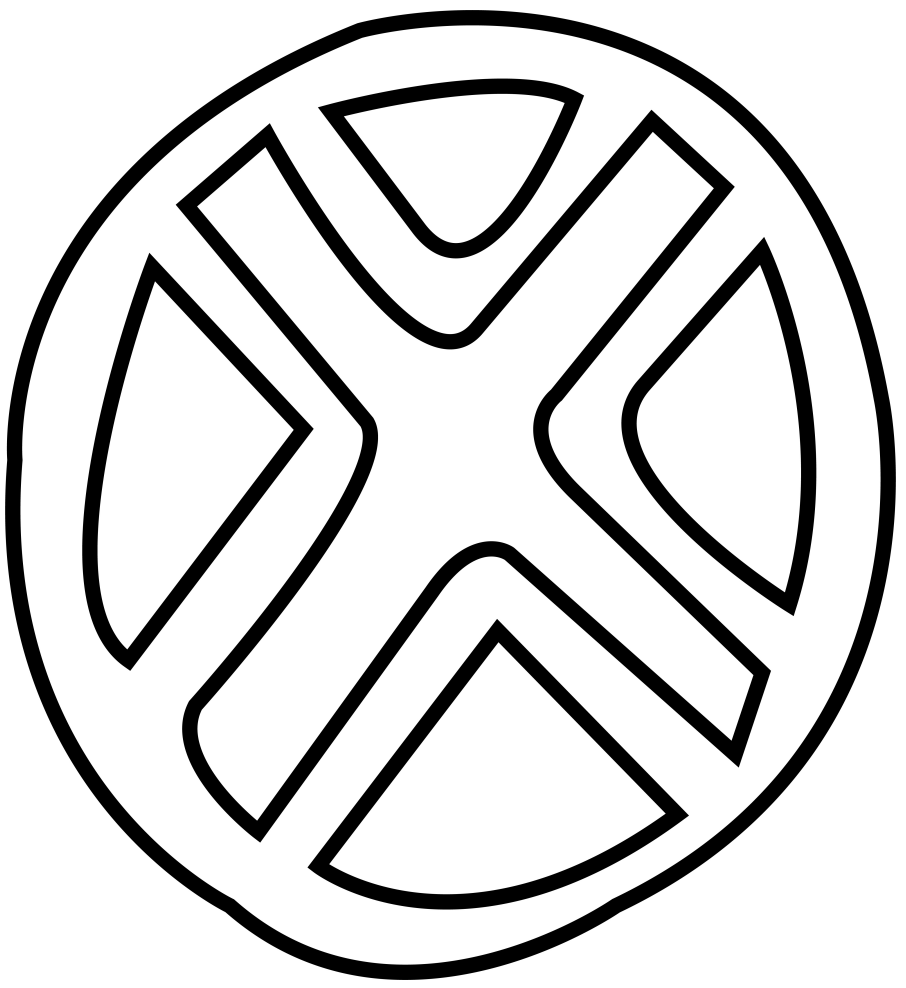

Representação sintética de cidade em unidade ideográfica do antigo Egito: um anel periférico delimitador (a muralha), duas vias que se cruzam em " $X$ " (indicam as portas de entrada e a presença de um centro) e os quadrantes (as quadras ou quarteirões). 


$$
y
$$




\section{Lista de ilustrações}

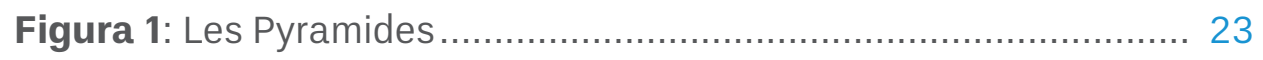

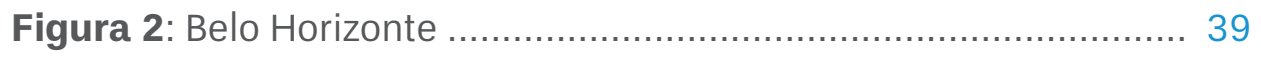

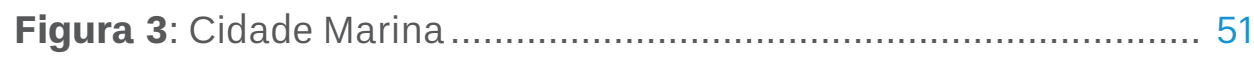

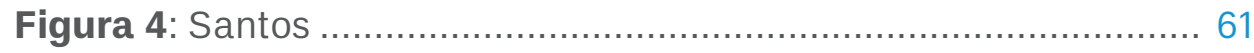

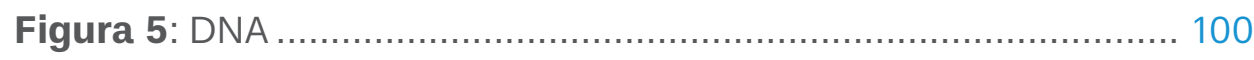

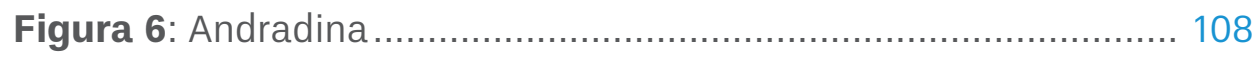

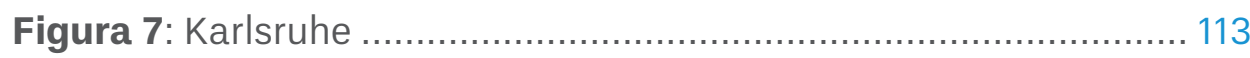

Figura 8: Serra do Navio ........................................................... 133

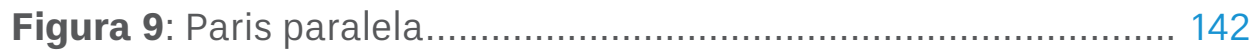

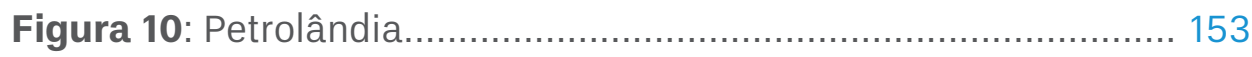

Figura 11: Cergy-Pontoise ................................................................ 165

Figura 12: Águas de São Pedro..................................................... 168

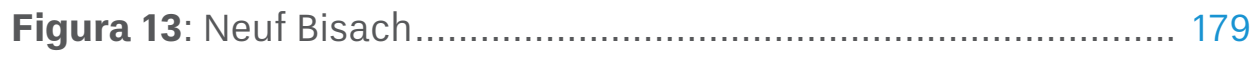

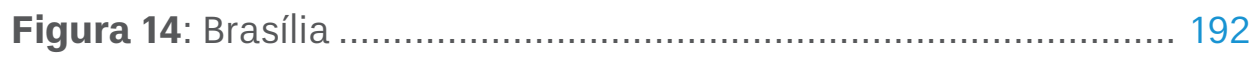

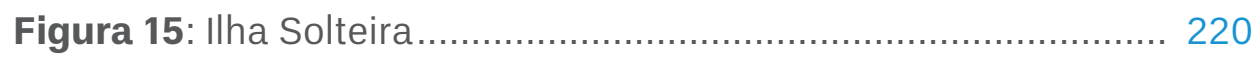

Figura 16: Rodovia Belém-Brasília .............................................. 243

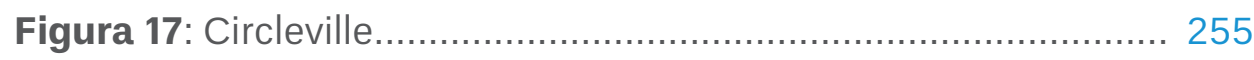

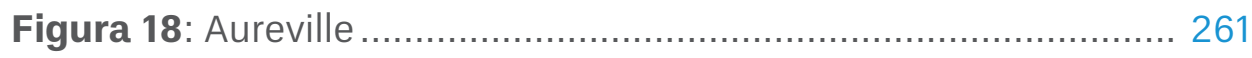




$$
y
$$




\section{Sumário}

Do quê e como pesquisar ........................................................11

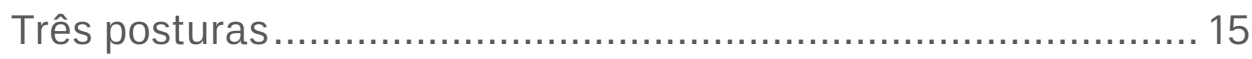

Abertura: uma questão, um caminho, uma viagem................... 19

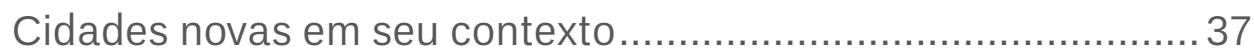

Cidades novas como um tipo do urbanismo ................................. 40

Cidades novas como ideais: da utopia à realidade........................ 45

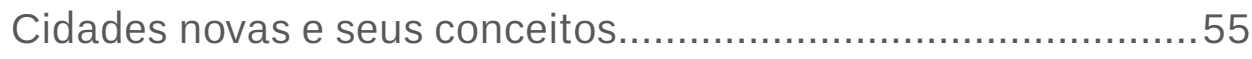

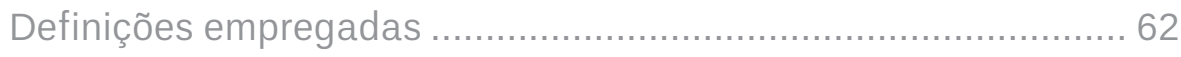

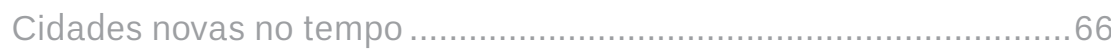

Cidades novas como laboratório socioespaciais .................................75

Definições-síntese e definições fracionadas........................................ 82

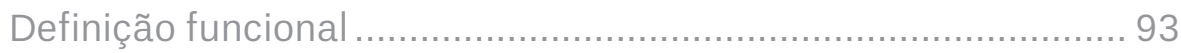

Capítulo 1. Cidades novas e o desejo ......................................... 103

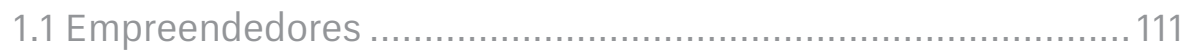

Poder público e suas cidades novas.................................................116

Setor privado e suas cidades novas ............................................... 125

Capítulo 2. Cidades novas e a necessidade ............................. 129

2.1 Funções e exemplares .........................................................135 
Capítulo 3. Cidades novas e o lugar.

Capítulo 4. Cidades novas e o profissional 167

4.1 Os projetistas de cidades novas

Capítulo 5. Cidades novas e o projeto

5.1 Do planejamento ao projeto

5.2 Cidades novas e suas formas 208

Traçado: cidades novas em 2D ...................................................... 214

Tecido: cidades novas em 3D ......................................................229

Capítulo 6. Cidades novas e o tempo ......................................239

Considerações finais: no caminho, as cidades novas 259 


\section{Do quê e como pesquisar}

\section{Sylvia Ficher}

Em 2004 recebi um presente do meu colega Carlos Roberto Monteiro de Andrade - para aqueles que sabem das coisas, o Mancha. Presente raro, que não se recebe todos os dias: um candidato a doutorado já pesquisador experiente e com objetos de estudo amplamente sedimentados. E assim Ricardo Trevisan entrou para a minha vida, inicialmente como orientando, para se tornar amigo dileto e, hoje, colega na Faculdade de Arquitetura e Urbanismo da Universidade de Brasília.

Sua trajetória intelectual só pode ser qualificada como afortunada. Considerando-se o seu pendor para os estudos acadêmicos, teve a sorte de entrar em 1994 para o curso de graduação em Arquitetura e Urbanismo da Escola de Engenharia de São Carlos, USP/São Carlos, curso este diferenciado justamente por sua tradição de associar ensino e investigação.

Lá passou a integrar o Archab, grupo de pesquisa liderado por Nabil Bonduki que iria produzir o mais extenso levantamento sobre habitação social no Brasil, desvelando a excepcional contribuição dos Institutos de Aposentadoria e Pensões - e que teve, entre seus principais produtos, o aclamado livro de Nabil, Origens da habitação social no Brasil (1998).

O destino estava traçado. Familiarizando-se com a prática da investigação, Ricardo tomava a habitação social como um primeiro tema de interesse. Bolsista de Iniciação Científica da Fapesp, em 1998 levou a cabo o ambicioso projeto Cidades novas de colonização e expansão territorial no noroeste do Estado de São Paulo (1930-1964), sob a orientação gabaritada de Mancha e Sarah Feldman. Foi um ano de leituras, visitas e sistematização de informações que resultou não só no 
levantamento de 42 cidades novas - valendo-se de uma fonte até hoje pouco explorada, a Enciclopédia dos municípios brasileiros -, mas também na definitiva sedução por mais dois temas, a formação da rede urbana brasileira e, nela, o papel das cidades novas. Temas suficientes para dar um sabor muito pessoal para suas reflexões.

Com o diploma de arquiteto e urbanista no bolso, em 1999 Ricardo passa seis meses em Londres para aprofundar os conhecimentos sobre a garden city. Tendo visitado alguns de seus mais significativos exemplares, como Letchworth e Welwyn, essa viagem daria o mote para o mestrado, realizado de 2001 a 2003 no Programa de Pós-Graduação em Engenharia Urbana da Universidade Federal de São Carlos, UFSCar, sob a orientação de Ricardo Siloto da Silva, mais uma vez como bolsista da Fapesp. Sua dissertação, Incorporação do ideário da garden-city inglesa na urbanística moderna brasileira: Águas de São Pedro, apresentava a estância hidromineral paulista projetada pelo engenheiro Jorge de Macedo Vieira em 1936 à nossa história urbana.

Já não haveria escapatória, diante de si impunha-se a carreira universitária. De 2003 a 2004, Ricardo leciona na Universidade Federal de Uberlândia, transferindo-se em seguida para a Universidade Estadual de Goiás. Tendo se achegado ao centro-oeste e já irrompido na minha vida, em 2006 foi aceito no doutorado da FAU/UnB, tendo o intuito de mapear o processo de projetação de cidades no território nacional. Contando com bolsa para doutorado sanduíche do CNPq, permanece de 2007 a 2008 na Europa, vinculado ao Laboratoire Architecture-Culture-Sociétés (ACS) da École Nationale Supérieure d'Architecture de Paris-Malaquais, sob a supervisão de Monique Eleb. Manteve então contatos com pesquisadores do calibre de Philippe Panerai, Jean-Louis Cohen, Donatella Calabi e Martino Tattara.

Tal intercâmbio rendeu uma guinada no desenvolvimento do doutorado, que passou a ter como objetivo melhor conceituar aquela tipologia urbana que havia tomado a imaginação de Ricardo. Em outras palavras, o desafio que ele se colocava seria responder a uma questão aparentemente banal: o que são cidades novas?

Note-se, não novas cidades em geral; afinal, toda e qualquer cidade um dia foi uma cidade nova, uma jovem cidade. Ou, já no registro do olhar obsessivo de 
pesquisador, aquelas aglomerações também denominadas: cidade nova planejada; cidade artificial; cidade protótipo; cidade de proveta; cidade construída de raiz; ville neuve; ville nouvelle; new town; cidade nova aberta; cidade nova fechada; cidade traçada; cidade planejada; cidade inventada; nova capital; nova vila; cidade concebida; cidade-sputnik; cidade ex nihilo; cidade plantada; introduced capital; cidade nascida radicalmente nova; cidade de nova fundação; cidade ideal; navyé goroda; new-town in-town; terra de Canaã; cidade concebida a priori; cidade regular; cidade surgida do nada; neue städte; twin towns; ciudad nueva; cidade de raiz; new communities; cidade concebida ex-novo; città nuova; cidade partindo do nada; cidades socialistas; cidade encomendada; cidade projetada; cidade-satélite; modoun eg gegida; città di fondazione; cidades de vontade; cidade-objeto; cidade fabricada; centro urbano novo; cidade por decreto; nuevos pueblos; cidade criada; 新しい町.

Fruto de excepcional esforço de síntese de noção tão complexa e aberta a divergências, o resultado é a tese modestamente intitulada Cidades novas. Estudo único no gênero, não só entre nós, mas no plano internacional, merece a divulgação que ora recebe, não sendo demais recomendar sua edição também em línguas estrangeiras.

Vejamos em que reside tanta excepcionalidade.

Ao buscar estabelecer uma base teórica para sua resposta, Ricardo definiu seis atributos ou genes, que deveriam estar associados em certa medida a uma aglomeração de modo a permitir classificá-la como legítimo espécime de cidade nova. Segundo ele, em um dado contexto político, econômico, social e/ou cultural podem ser consideradas como cidades novas aquelas: 1) promovidas por decisões determinadas pelo poder público ou pela iniciativa privada; 2) criadas para atender, ao menos em intenção e/ou de início, a uma ou mais demandas funcionais; 3) implantadas, portanto, em sítios presumivelmente acertados; 4) concebidas a partir de um projeto de caráter urbanístico; 5) de autoria de agentes especializados, eventualmente profissionalmente qualificados; e, por fim, 6) materializadas em tempo relativamente curto e, assim, com fundação e até mesmo data de inauguração razoavelmente estabelecida. Vontade, razão de ser, local, autores, projeto e tempo, 
seis genes inseparáveis constituindo como que o DNA da cidade nova, por sua vez articulados à longa duração da urbanização.

Mas como comprovar tal conceituação? Pelo método indutivo do registro empírico, amealhando cidades novas. Desse procedimento foi extraída a estrutura da tese: seis capítulos, cada um detalhando um gene, por sua vez ilustrado por exemplares de cidades novas de diferentes períodos e lugares, escolhidas por sua maior capacidade elucidativa. Procedimento esse que pode ser estendido ao infinito, de modo a demonstrar a abrangência da conceituação e ampliar as possibilidades de constituintes a serem nela integrados, autorizando a generalização de determinadas conclusões.

O resto é história... Defendido o doutorado em 2009, Ricardo teve seu trabalho reconhecido com o Prêmio Capes de Teses 2010. Como que parte da justa láurea, naquele ano havia entrado para o corpo docente da FAU/UnB. No mesmo pacote, ganhou o direito a um período de estudos pós-doutorados, que realizaria de 2014 a 2015 na Graduate School of Architecture, Planning and Historic Preservation da Columbia University. Sob a supervisão de Gwendolyn Wright, retornou àquele seu primeiro tema, a habitação.

Temas tão ricos ainda vão render muito. Como dele não posso mais me livrar, só me resta aguardar ansiosa a continuação das pesquisas de Ricardo Trevisan, que certamente irão contribuir para o entendimento desta que é, como bem indica a etimologia de seu nome, a fundação e o fundamento da civilização.

Brasília, 21 de março de 2018. 


\section{Três posturas}

\section{Philippe Panerai}

\section{Professor honorário}

Membro da Académie d'Architecture

Grand Prix de L'Urbanisme

Meu primeiro encontro com o Brasil se deu em Brasília, em 1986, quando do $2^{\circ}$ Seminário sobre Desenho Urbano (SEDUR), tendo por tema a pesquisa em urbanismo. Vinte anos antes de Ricardo Trevisan se engajar no estudo do qual resultaria sua tese doutoral e que, com as adaptações de praxe, fornece a matéria do presente livro.

Vinte anos que marcam nossa passagem de um século a outro, 20 anos que marcam o amadurecimento da questão urbana na pesquisa brasileira para a qual Ricardo traz uma contribuição decisiva. O interesse de seu trabalho está no encontro de três posturas que, a meu ver, constituem as qualidades de um pesquisador em arquitetura e em urbanismo: uma excepcional abertura intelectual, uma cultura sólida, uma paixão pela pesquisa de campo.

A abertura intelectual - que poderíamos igualmente denominar, dando-lhe maior nobreza, de curiosidade científica - manifesta-se de início pela distância que Ricardo soube tomar em relação a Brasília, ícone incontestável da cidade nova do século XX, que além do mais é cidade nova e capital. De fato, Brasília pode ser uma armadilha forte pelo fascínio que ela exerce (e eu sei do que falo, por tê-lo experimentado). Ricardo soube escapar da teia de aranha que teceu Lucio Costa, não que a nova capital do Brasil esteja ausente, o que seria obviamente ridículo, mas ela não é a única, ela não está no centro do trabalho, ela não cerceia o pesquisador. Pelo contrário, somos levados a uma agradável viagem pelos séculos e continentes, com igual interesse por 
experiências modestas e ambiciosas: de um simples loteamento, de uma pequena bastide até exemplares bem conhecidos, como São Petersburgo ou Belo Horizonte.

A cultura é sólida, isso é inegável. Para nos convencer, basta examinar a bibliografia - é por ela que os leitores sagazes sempre iniciam um livro para terem uma ideia do que passou pela cabeça do autor. Mas ela não para por aí; além de testemunhar a abertura intelectual já mencionada, seus títulos não só percorrem séculos e continentes, como misturam nacionalidades e línguas: português, inglês, francês, além do italiano, espanhol, alemão, húngaro, indiano... Sobretudo, os conhecimentos profundamente assimilados e integrados resultaram em uma obra clara, estruturada em dois textos introdutórios, "Cidades novas em seu contexto" e "Cidades novas e seus conceitos", que abrem magnificamente a questão, aos quais se sucedem seis capítulos, cada um deles dedicado a um tema: o desejo, a necessidade, o lugar, o profissional, o projeto e o tempo, que são maneiras diferentes e levemente deslocadas de abordar uma realidade complexa. No plano do método, trata-se de um exercício particularmente estimulante em que podemos observar em ação uma cultura viva que vai além da simples acumulação erudita.

A apropriação dessa cultura que o trabalho de Ricardo demonstra depende em muito, acredito, do seu gosto pela pesquisa de campo. Sem dúvida, ele não pôde (ainda) visitar todos os lugares de que nos fala e que nos apresenta por meio de plantas, fotos ou croquis, mas conhece muitos deles de primeira mão. E soube como chegar lá, soube percorrê-los a pé, revelando suas emoções, suas surpresas, suas dificuldades. Desse modo, seu esforço demonstra a necessidade do pesquisador arquiteto e urbanista, tanto quanto o geógrafo ou o sociólogo, de abandonar o teclado de seu computador para ir a campo testar incansavelmente a realidade dos lugares. Esta me parece ser uma terceira lição a extrair deste trabalho.

Para concluir, como não se comover com a introdução que Ricardo faz de sua obra: “Manhã pouco ensolarada, de temperatura agradável para um dia de verão na capital francesa. Igualmente agradável para a primeira visita a uma cidade nova na região da Grande Paris, Évry. Parto da Cité Universitaire às 9h30 da manhã. 
Na estação do trem suburbano (RER), a compra do bilhete ida e volta me proporciona uma surpresa inicial. No guichê, meu destino, a estação de Évry-Courcourrone, faz os funcionários da RATP me olharem espantados.” Os ponteiros do relógio giram para trás em alta velocidade e revejo Ricardo, em julho de 2008: ele acabara de sair do meu escritório na rue des Feuillantines para explorar a cidade nova de Évry...

Obrigado, Ricardo, mergulhei com grande prazer em toda esta história e estou muito contente que seu esforço seja publicado e, assim, disponibilizado a um maior número de estudantes e de profissionais, com uma última observação: certamente merece ser traduzido ao menos para o francês e o inglês.

Paris, 2 de abril de 2018. 


$$
y
$$




\section{Abertura: uma questão, um caminho, uma viagem}

Paris, 3 de julho de 2008.

Manhã pouco ensolarada, de temperatura agradável para um dia de verão na capital francesa. Igualmente agradável para a primeira visita a uma cidade nova na região da Grande Paris, Évry.

Parto da Cité Universitaire às 9h30 da manhã. Na estação do trem suburbano (RER), a compra do bilhete de ida e volta me proporciona uma surpresa inicial. No guichê, meu destino, a estação de Évry-Courcourrone, faz os funcionários da RATP me olharem espantados. “O que um estrangeiro vai fazer em Évry?”, devem ter pensado. Percebi que a situação era merecedora de explicação. Como resposta, relatei que estudo cidades novas, as francesas villes nouvelles, e que a viagem seria necessária para minhas pesquisas. Entre a efetuação da compra e a emissão dos bilhetes, não posso deixar de ouvir algumas passagens do diálogo entres eles: "Fazer o quê numa cidade de interior?” ou “Ah, é aquela cidade onde as pessoas saem para trabalhar em Paris”. Após esse primeiro contato com meu objeto de análise e pagar € 9,90 pela passagem, sigo para a plataforma. Itinerário: RER B rumo à estação Châtelet; de lá, tomo o metrô da linha 14 até Gare de Lyon, onde encontro a arquiteta Renata Ralid, companheira nessa aventura e amiga dos tempos de faculdade na USP de São Carlos.

Um café à espera do RER D, que nunca chegou por problemas de circulação. A alternativa: pegar um trem da SNCF (grandes lignes) na plataforma "L”, rumo ao sudeste da região metropolitana, parando em inúmeras estações pelo caminho. Uns 40 minutos depois, chegamos a Évry. Nos primeiros 15 minutos da viagem, tinha-se a presença da mancha urbana contínua, com bairros residenciais de baixa densidade, algumas torres habitacionais aqui e acolá, uma infinidade de galpões 
industriais entremeados por desmanches de carros, por vezes um novo centro de bairro, mais uma estação, mais uma partida. Aos poucos, os espaços cinzentos ao longo da via férrea iam sendo substituídos por campinas: era a presença da campagne, da natureza, começando a se sobressair entre as construções urbanas.

Chegamos à estação de Évry-Courcourrone/Préfecture por volta das $11 \mathrm{~h} 10$. Diferentemente das estações anteriores (plataformas simples, em superfície, de estruturas metálicas), essa estação é uma caixa de concreto semienterrada, com pé-direito alto, escadas rolantes e um número significativo de usuários. De pronto, percebi que estávamos num centro urbano diferenciado. Subimos ao pavimento térreo, onde nos deparamos com duas alternativas de saída: Agora (Ágora) e Théâtre (Teatro) do lado esquerdo ou Cathédral (Matriz) e Mairie (Prefeitura) do lado direito. Como a vista de dentro da gare favorecia a paisagem à direita, tendo a surpreendente igreja do arquiteto suíço Mario Botta como ponto focal, seguimos por essa saída.

A princípio, é uma cidade feita de tijolos. Não apenas a igreja com pedigree, mas com a maioria dos prédios ao seu redor expondo, em suas fachadas, um tijolo vermelho contrastante com o céu azul semiencoberto. A entrada da estação ficou para trás; à nossa frente, a Praça das Nações. Uma esplanada pontuada por árvores e cortada por fontes d’água. Em seu contorno, a igreja matriz, centralizada, ladeada por duas edificações multifuncionais: à direita, um edifício de serviços e comércios; à esquerda, a sede da administração municipal.

Após uma rápida visita à igreja - de 800 mil tijolos, com iluminação zenital e coroada por 24 árvores -, entramos na prefeitura em busca de material para a pesquisa. Conseguimos apenas o mapa da cidade, indispensável num ambiente desconhecido.

Nele, observo que as vias em branco são para veículos e em amarelo para pedestres, quase sempre dissociadas, indício da influência do urbanismo funcionalista na concepção da cidade. Ademais, os edifícios vistos inicialmente, dispostos regularmente face às ruas e avenidas, haviam cedido lugar para edifícios distribuídos irregularmente. E não somente uma implantação irregular, mas também uma composição volumétrica diferenciada. Não estávamos numa cidade tradicional. 
Identifiquei duas causas para tal percepção: a ausência, típica em cidades modernistas, do parcelamento do solo em lotes; e, como consequência, a presença de quarteirões delimitados por vias veiculares e permeados por caminhos para pedestres.

Tal disposição gerou aquilo que denominei de uma desordem voluntária e consciente. Não uma desordem espontânea, como aquela de cidades convencionais, mas uma tentativa artificial de dispor os edifícios de modo irregular, de desordená-los segundo uma lógica própria, um partido ideológico-conceitual específico.

Se, por um lado, essa desordem voluntária e consciente favoreceu o surgimento de inúmeros espaços públicos, além de uma variedade de percursos para pedestres, por outro, gerou inúmeros espaços residuais, locais de baixa qualidade espacial quanto ao uso, ermos, sem cuidados, “espaços cegos”, diria o urbanista Frederico de Holanda.

A caminho da Ágora, a calçada, no nível térreo, se transforma em escadarias. A partir daí, nosso deslocamento será num pavimento superior, por passarelas ziguezagueantes. Tal separação entre pedestres e veículos pode ser positiva em áreas estritamente residenciais - como nas unidades de vizinhança americanas ou nas superquadras brasilienses e seus passeios seguros para crianças -, mas em Évry, sua adoção nas áreas centrais de maior caráter comercial resultou, a meu ver, negativa. Por que distanciar aquele que passa de automóvel, potencial consumidor, dos serviços prestados na região? A contragosto, as vias centrais assumem a função única de circulação veicular. Suas vitrines e placas indicativas dos serviços ofertados foram realocadas para um nível superior, para um espaço privatizado, a Ágora.

Ah, a Ágora! Pasmo fiquei ao perceber que o seu conceito original - uma praça com acesso livre e atividades diversas - havia se transformado numa galeria comercial, num shopping center. Embora abrigando equipamentos culturais e esportivos em seu interior (convívio, teatro e piscina), seu usuário é obrigado a adentrar o edifício para acessá-los. O espaço público das ruas comerciais perdeu seu posto para o espaço privado, com suas redes de restaurantes fast-food, suas lojas padronizadas, seus corredores herméticos e seus vigilantes sempre atentos. 
Uma parada para o almoço. Momento em que percebemos uma diferença de comportamento nos habitantes de Évry: eles são mais gentis que os parisienses, algo típico de cidades do interior!

Ao sair daquele centro enclausurado, verifiquei que a arquitetura de tijolos havia se dissipado, substituída por edifícios com arquitetura peculiar à época de criação da cidade, os anos 1970. Um exemplo é a Préfecture, sede administrativa do Departamento da Região de Essone. Um complexo de edifícios em barra, com empenas de concreto aparente e fachadas envidraçadas, isolados por amplos espelhos d'água. Algo destoante do restante da cidade: uma superquadra e seu superbloco!

Vamos em direção ao bairro denominado Les Pyramides (As Pirâmides), o percurso feito sempre acima das ruas de Évry, por passarelas ou edifícios-pontes. Ao passar por uma delas, outra superquadra e sua arquitetura, dessa vez residencial. Encontram-se ali edifícios habitacionais de até oito pavimentos, térreos reservados a salas comerciais ou de serviços - em grande parte abandonadas -, circundando um amplo pátio interno arborizado de livre acesso, algo semelhante às superquadras brasilienses, porém sem a mesma fluidez visual au rez-de-chaussée.

Prosseguindo em nossa promenade, um edifício com fachadas multifacetadas em vidro espelhado num tom amarelado chamou minha atenção por suas funções. Trata-se de um complexo multifuncional, com serviços e comércio no nível superior, onde nos encontrávamos, e terminal de ônibus urbano no nível inferior (vias). Os espaços que surgiam entre as partes desse edifício se transformaram em singelos belvederes, com vista para espelhos d’água e para Les Pyramides.

Clara ficou a origem do nome: prédios escalonados, zigurates, com um gabarito de até oito pavimentos. De relance, eles apresentam boas condições, tendo a maioria de suas varandas ajardinadas - quiçá uma referência aos Jardins Suspensos da Babilônia! Todavia, ao atravessar uma passarela à la Santiago Calatrava, chegamos numa superquadra também de pirâmides, porém em situação oposta às primeiras. A precariedade da manutenção das edificações, ocupadas por classes sociais de menor poder econômico, era perceptível nos balcões abandonados ou servindo de depósito para quinquilharias, 
no comércio fechado, nas portarias depredadas, nas fachadas deterioradas. O ponto positivo encontrado foi a presença de inúmeros equipamentos - creche, biblioteca, escola, playgrounds etc. - em boas condições e sendo utilizados pela população local.

Figura 1: Les Pyramides

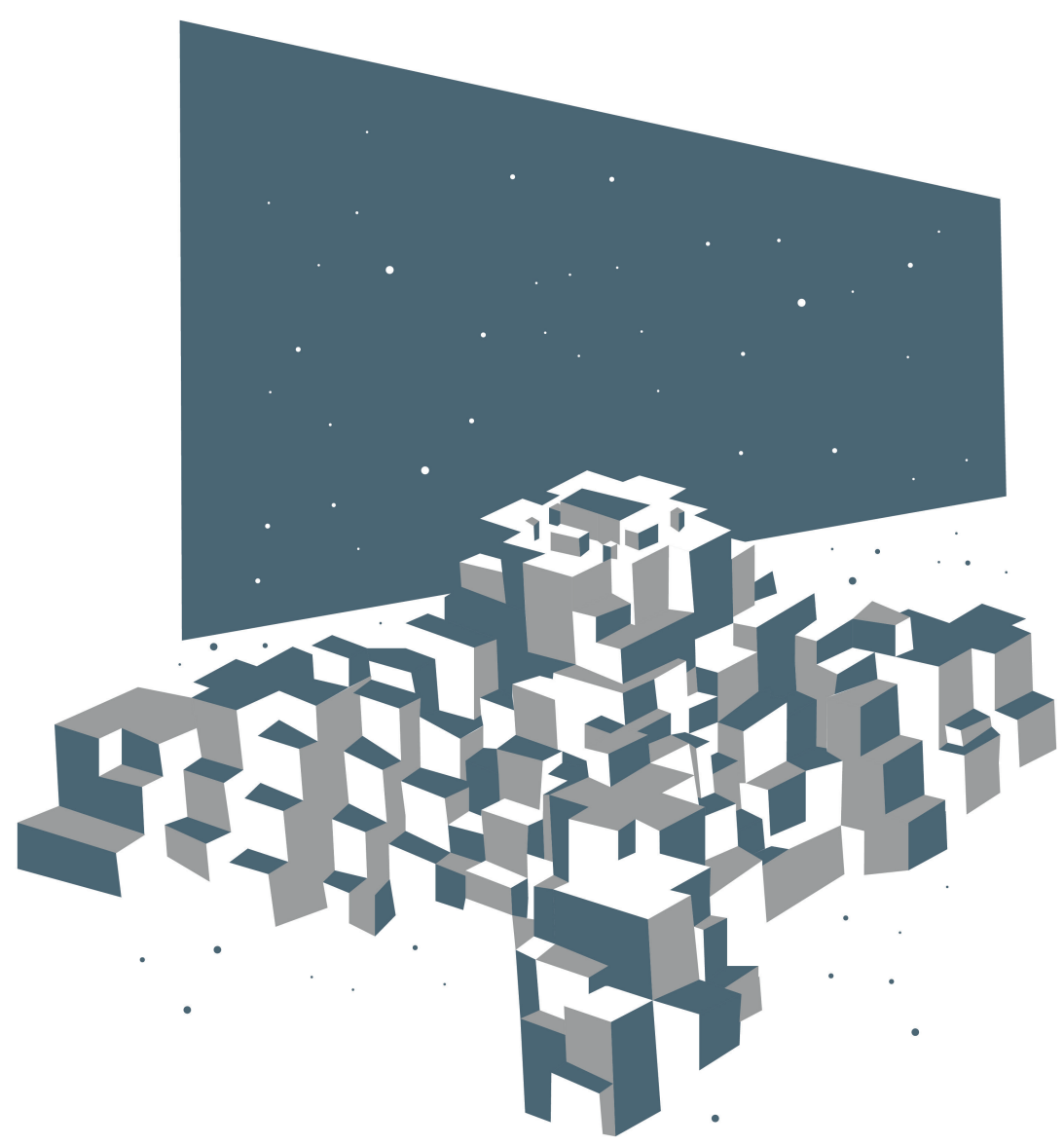


À medida que caminhávamos rumo aos limites da cidade, ficou óbvio que a densidade diminuía. Os edifícios ficavam mais distantes entre si, levando a uma maior área de vazios, além de seu gabarito baixar para três e dois pavimentos. A forma piramidal, sempre constante na paisagem do bairro, era por vezes interrompida pela presença de alguns prédios em barra ou por pequenas torres de arquitetura experimental.

Os limites da cidade, nessa direção, são nitidamente traçados por avenidas largas com trânsito intenso. Chegara o momento de retornar ao centro. Caminho diferente ao da vinda, a volta nos revelou mais pirâmides e pequenas praças. Descobri algumas curiosidades, como a varanda de área quadrada, que foi dividida ao meio por uma parede de tijolos disposta diagonalmente. Ao separar o espaço em duas áreas externas de apartamentos distintos, o objetivo da obra pós-ocupação foi a privatização do terraço compartilhado.

Chegamos ao Centro Comercial, simples continuação da Ágora, porém com uma fachada mais ostentosa, elemento que faltava para configurá-lo como um verdadeiro mall! Além do cenário familiar, a constatação dos estacionamentos horizontais e verticais repletos de carros indicava duas possibilidades: ou o shopping estava abarrotado de gente (e garanto que não estava) ou os proprietários desses veículos utilizavam desse serviço para acessar a estação de trem rumo a Paris (fico com esta opção). Indícios de uma cidade-dormitório.

Ao deixar o Centro Comercial pela Ágora, nos deparamos com uma placa indicativa para a estação de Évry-Courcourrone/Préfecture. Não era o caminho que havíamos feito de início. Menos convidativo, optamos por segui-lo. O fluxo de pedestres é intenso. O trajeto começa por uma rampa de veículos ladeada por estreitas calçadas. Dessa rampa, continua-se por uma rua sinuosa, delimitada por um muro cego e pelas saídas de serviço dos prédios. Ao final, aproximadamente 200 metros depois da Ágora, se encontra a outra entrada da estação, aquela rejeitada por nós na chegada. A estreita rua de serviços é o espaço mais vivo e menos qualificado ambientalmente da cidade! Embora as condições físicas não caracterizem esse percurso como deveriam de fato, sendo a rua com maior trânsito de pessoas, 
entendi que seu uso intenso acontece por ser a ligação mais curta entre o Centro Comercial e a estação, ou melhor, entre o edifício-garagem e a estação.

Às 16h terminamos nossa deriva. Entramos na grande estrutura em concreto da estação em direção a Paris.

Attention à la marche en descendant du train...

Do caminho, a cidade.

(Henri Lefebvre, O direito à cidade, 1969 apud Panerai, 2006, p. 17).

Agradeço a todos por terem embarcado, sem consulta prévia, nessa breve viagem à cidade nova de Évry. Pela narrativa, pudemos vivenciar juntos a atmosfera que compõe essa cidade-satélite localizada nos arredores parisienses. Ao listar suas qualidades, encontramos, dentre outras, sua interligação com a cidade-mãe (Paris) pelo transporte ferroviário, de fácil acesso e com fluxo constante; sua arquitetura inusitada e experimental; suas funções centrais repaginadas (Ágora); seu urbanismo modernista; seu traçado diferenciado; suas superquadras com seus superblocos; seus espaços públicos diversificados; sua população educada e solícita; sua dependência de Paris. Uma cidade criada há 50 anos pelo governo francês para controle ordenado do crescimento da metrópole sobre um sítio previamente escolhido e produto das teorias arquitetônicas e urbanísticas em voga. Uma Cidade Nova.

Escolhi Évry, mas poderia ter sido qualquer outra, de semelhante origem, para introduzir o presente livro. Um chamariz para convidá-los a me acompanharem numa outra viagem, de maior importância. Trata-se de uma viagem conceitual, conduzida pela história e por teorias urbanas, passando por outras cidades novas no Brasil e no mundo, da Antiguidade ao presente. Uma viagem desbravadora, tendo como destino a essência que compõe essa personagem pouco explorada na urbanística brasileira. 
Identifico-me, para aqueles que se aventurarem, como perseverante pesquisador da temática Cidades Novas, daqui por diante CNs. Desde 1997, ainda graduando no Departamento de Arquitetura e Urbanismo da Escola de Engenharia de São Carlos da Universidade de São Paulo, entrei para o grupo de pesquisa Pioneiros da Habitação Social no Brasil, coordenado pelos professores Nabil George Bonduki, Sarah Feldman e Carlos Roberto Monteiro de Andrade. Como bolsista da Fapesp, iniciei um trabalho intitulado “Cidades novas de colonização e expansão territorial no Noroeste do estado de São Paulo (1930-1964)”. Em um ano de leituras, levantamentos, visitas in loco, sistematização de materiais, elaboração de relatórios, aproximei-me do universo de 42 CNs paulistas, das quais 12 foram escolhidas para uma análise mais detalhada de sua história e projeto. Além dessa, outras pesquisas no grupo tiveram como foco CNs implantadas no norte do estado do Paraná, assim como cidades empresariais paulistas. Ao final do projeto, conseguimos compreender o processo de ocupação e a formação da rede urbana nessa região do país atualmente tão próspera.

Os estudos prosseguiram, a partir de 2001, no mestrado no Programa de Pós-Graduação em Engenharia Urbana da Universidade Federal de São Carlos. Sob a orientação do professor Ricardo Siloto da Silva e novamente com o apoio financeiro da Fapesp, direcionei minha atenção, dessa vez, para uma única CN e sua relação com os conceitos de cidade-jardim. Com o título "Incorporação do ideário da garden-city inglesa na Urbanística Moderna Brasileira: Águas de São Pedro”, a dissertação defendeu a estância hidromineral paulista, projetada pelo engenheiro Jorge de Macedo Vieira em 1936, como a primeira cidade-jardim brasileira. A leitura histórico-conceitual das teorias urbanas do pós-Revolução Industrial, o entendimento da proposta howardiana de cidade ideal - inclusive com visitas a Letchworth e Welwyn Garden City, seus primeiros exemplos na Inglaterra -, a ressonância de tal tipo no Brasil e a desconstrução do projeto urbano de Águas de São Pedro proporcionaram tal confirmação.

Em 2005, após um primeiro contato com aquela que seria a orientadora da tese da qual este livro se origina, professora Sylvia Ficher, levei adiante meus estudos. 
A princípio, a proposta era ampliar o horizonte de pesquisa para todo o território nacional, tendo o século XX como período fulcral. Ao ingressar, em abril de 2006, no Programa de Pós-Graduação em Arquitetura e Urbanismo da Faculdade de Arquitetura e Urbanismo da Universidade de Brasília, a versão original foi nomeada: “Do traço, um Brasil urbano. Cidades novas planejadas: 1889 - 1988”. Vinculado à linha de pesquisa “Teoria, história e crítica”, o intuito era revelar um país de inúmeras cidades projetadas, distante de uma visão que, quase sempre, reconhece apenas quatro exemplares: Belo Horizonte, Goiânia, Brasília e Palmas, tendo como delimitação temporal a Proclamação da República - ou a origem de Belo Horizonte, 1893 - e a última Constituição Federal - ou a fundação de Palmas, 1989. Para isso, dividiu-se o período de cem anos em quatro, cujos exemplares mais significativos seriam analisados quanto à sua história, traçado urbano, projetista etc.

Todavia, tal proposta foi adiada em decorrência de dois episódios particulares. O primeiro refere-se às arguições feitas pelos professores Frederico de Holanda (UnB) e Marco Aurélio Andrade de Filgueiras Gomes (UFBA) na qualificação do projeto de tese, em abril de 2007. O segundo foi o estágio-doutorado realizado em Paris e Veneza entre agosto de 2007 e agosto de 2008.

Com a contribuição daqueles professores e as subsequentes orientações de Sylvia, identifiquei os obstáculos que, talvez, me impossibilitassem de concluir a tese em tempo hábil com a qualidade científica almejada. A ideia inicial se mostrava uma tarefa árdua, pois o número de CNs não parava de aumentar. ${ }^{1}$ Ademais, até então, os principais aspectos que caracterizam esse fenômeno urbanístico eram vagos - mesmo após anos de pesquisa direcionada.

Já a temporada em Paris, sob a tutela dos professores Monique Eleb e Philippe Panerai, e em Veneza, sob a supervisão da professora Donatella Calabi, propiciou a visita a outros exemplares, como Évry. Mas, fundamentalmente, colocou-me em

1 O projeto de pesquisa “Atlas de cidades novas no Brasil Republicano”, iniciado em 2014, vinculado ao grupo de pesquisa Paisagem, Projeto e Planejamento - Labeurbe (FAU-UnB) e à Cronologia do Pensamento Urbanístico (http://www.cronologiadourbanismo.ufba.br/) já identificou mais de 260 exemplares de cidades novas propositados em território nacional no século XX. 
contato com uma vasta e riquíssima bibliografia sobre CNs. Esse tête-à-tête com meu objeto de estudo fez novas portas se abrirem, e um mundo de informações se revelaram. Um momento de reflexão era necessário.

Ambas as experiências, qualificação e estágio-doutorado, após um período de sedimentação das inúmeras ideias e questionamentos que afloravam, permitiram-me chegar a um denominador comum para o fio condutor da tese. $\mathrm{O}$ fato de ter estudado e visitado inúmeras CNs, como: Brasília (DF), Belo Horizonte (MG), La Plata (Argentina), Santiago (Chile), Goiânia (GO), Andradina (SP), Guarujá (SP), Santos (SP), Adamantina (SP), Lucélia (SP), Votuporanga (SP), Águas de São Pedro (SP), Cosmorama (SP), Jales (SP), Oswaldo Cruz (SP), Panorama (SP), Aracaju (SE), Letchworth (Inglaterra), Welwyn Garden City (Inglaterra), Barcelona (Espanha), Marne-la-Vallée (França), Cergy-Pontoise (França), Cingapura (Cingapura), Tapiola (Finlândia) e mesmo Évry, não me habilitava como expert em CNs. Relatórios, artigos e dissertação, embora pertinentes quando escritos, não me atentaram a responder uma simples questão: o que são cidades novas?

Resumidamente, conceituo CNs como núcleos urbanos criados: 1) pelo desejo do poder público ou da iniciativa privada e concretizado em ações específicas; 2) para buscar atender, ao menos de início, a uma ou mais funções dominantes (administrativa, de colonização, ferroviária, de realocação, balneária, satélite etc.); 3) em um sítio previamente escolhido; 4) a partir de um projeto urbanístico; 5) por agente(s) definido(s) - eventualmente profissional(is) habilitado(s); e 6) em um limite temporal determinado, implicando, inclusive, em um momento de fundação razoavelmente preciso.

Se, num primeiro instante, este aparenta ser um tema simples e já resolvido, procurarei logo dissuadir o leitor. Pretendo mostrar que tais evidências preliminares camuflam algo mais denso, auspicioso de ser explorado.

Enfim, um questionamento pessoal transformado em roteiro para nossa viagem. 
Cidades novas é um livro que busca revelar os significados para esse fenômeno, um tipo à parte segundo a literatura especializada. Duas palavras que, unidas, simbolizam um fenômeno que acompanha o processo de urbanização desde sua origem. No plural, para abranger o conjunto de denominações encontradas em diferentes obras, como: “cidade nova planejada”; “cidade artificial”; “cidade protótipo”; “cidade de proveta”; “cidade construída de raiz”; “ville neuve”; “ville nouvelle”; "new town”; “cidade nova aberta”; “cidade nova fechada”; “cidade traçada”; “cidade planejada”; “cidade inventada”; “nova capital”; “nova vila”; “cidade concebida”; “cidade-sputnik”; “cidade ex nihilo”; “cidade plantada”; “introduced capital”; “cidade nascida radicalmente nova”; “cidade de nova fundação”; “cidade ideal”; "navyé goroda”; “new-town in-town”; "terra de Canaã”; “cidade concebida a priori”; “cidade regular”; “cidade surgida do nada”; "neue städte”; "twin towns”; “ciudad nueva”; “cidade de raiz”; “new communities”; “cidade concebida ex-novo”; “città nuova”; “cidade partindo do nada”; “cidades socialistas”; “cidade encomendada”; “cidade projetada”; “cidade-satélite”; “modoun eg gegida”; “città di fondazione”; “cidades de vontade”; “cidade-objeto”; “cidade fabricada”; “centro urbano novo”; “cidade por decreto”; “nuevos pueblos”; “cidade criada”; “新しい町”. Uma variedade de expressões para definir algo que, na essência, tem o mesmo sentido.

Veremos ao longo de nossa viagem que são termos empregados para caracterizar: a origem e a fundação de cidades; o desejo em criá-las; a função para que foram idealizadas; o tipo urbano adotado; a presença de um profissional responsável por planejá-las, planificá-las, projetá-las; sua localização estratégica etc. Termos empregados em diferentes línguas, épocas e situações. Termos empregados, a meu entender, com um único propósito: referir-se às CNs.

Distante do determinismo praticado por alguns autores em aplicar um único termo, tiro partido dos existentes, sem distinção nem exclusão, para revelar que são todos análogos. Seja qual for sua variação, cada expressão poderá ser utilizada no momento oportuno.

Assim intitulado, considero Cidades novas um estudo sistemático e generalista. 
Um enfoque sistemático é um enfoque teórico, já apontava George G. Simpson em 1961 (LÉVI-STRAUSS, 2002, p. 24-25). Consciente disso, busco, pela abordagem sistemática, “ordenar” as informações e fatos dispersos na literatura nacional e estrangeira a fim de estabelecer, teoricamente, parâmetros para a compreensão e entendimento das CNs.

Os títulos que tratam desse fenômeno urbanístico no Brasil são, em geral, estudos pontuais sobre modelos de fato construídos. Veja-se: Pierre Monbeig (1949) contextualiza a ocupação do oeste paulista e norte paranaense por meio da criação de dezenas de cidades; Roberta Marx Delson (1979) pontua as vilas de nova fundação no Brasil Colônia; Murillo Marx (1980) faz menção àquelas do período imperial (Teresina e Aracaju); Yves Bruand (1981) analisa apenas as cidades administrativas (Belo Horizonte, Goiânia e Brasília); Maria Cristina da Silva Leme (1999) organiza um capítulo sobre as novas capitais; Nestor Goulart Reis Filho (2000b) expõe a história do surgimento das cidades no país; Renato Leão Rego (2009) explora as cidades plantadas por capital privado no norte-paranaense. Mesmo trabalhos recentes, como aqueles encontrados nos anais de nossos principais eventos científicos sobre urbanismo, como os encontros nacionais da ANPUR e da ANPARQ e o Seminário da História da Cidade e do Urbanismo, apresentam somente estudos de casos ou abordagens tangenciais. Não há, portanto, uma efetiva discussão teórico-conceitual.

Já a ampla literatura estrangeira sobre o assunto ${ }^{2}$ trabalha a questão conceitual, porém a partir de exemplares realizados longe de nosso território e por meio de teorias descontextualizadas de nossa realidade.

2 Citam-se, dentre inúmeros, os trabalhos: The ideal city: from Plato to Howard (LANG, 1952); Toward new towns for America (STEIN, 1957); L'idea della Città Giardino (GIORDANO, 1962); New towns of middle ages (BERESFORD, 1967); Les cités de l'avenir (RAGON, 1967); Les villes nouvelles e Les villes nouvelles en France (MERLIN, 1969a e 1991); New towns in America: the design and development process (BAILEY, 1973); New towns. Their origins, achievements and progress (OSBORN \& WHITTICK, 1977); New towns revisited (HALL, 1983); Les villes nouvelles dans le monde (CHALINE, 1985); Villes neuves et villes nouvelles (PANERAI et al, 1986); Ville nouvelle (CHOAY, 1988); Villes nouvelles et villes traditionelles (HAUMONT et al, 1999); Planning twentieth century capital cities (GORDON, 2006). Somam-se a esses referenciais as instituições estrangeiras criadas especialmente para discutir CNs, como o International New Towns Institute (INTI) e a International New Towns Association (INTA), ambas sediadas na Holanda. 
Consciente da ausência de obras conceituais no cenário nacional e, igualmente, de teorias contextualizadas à nossa realidade em âmbito estrangeiro, resolvi aceitar o desafio colocado pelo professor Carlos Roberto M. de Andrade em seu artigo “A construção historiográfica da cidade e do urbanismo moderno no Brasil: o caso das cidades novas planejadas” (PINHEIRO; GOMES, 2005, p. 73-90), que instiga pesquisadores a ampliar a abordagem ainda restrita sobre o assunto. Assim, dispus-me a construir uma teoria made in Brazil sobre CNs.

No mais, Cidades novas é também um estudo generalista, ao "recompor seus fragmentos”, partes dispersas encontradas na literatura, numa "imagem ordenada e significativa”, como conceitua Lewis Mumford (1969, p. 5).

Imaginemos o quebra-cabeça. Sua montagem pode ser considerada um processo de ordenamento dos fragmentos de uma única imagem, dispersos aleatoriamente no espaço. Para construir a imagem, o jogador deverá passar por uma longa fase de tentativas (erros e acertos), em que a perplexidade, a multiplicidade e a similaridade entre as peças dificultarão seu objetivo. Conforme passa o tempo, o jogador estabelece um entendimento maior sobre sua figura, o que torna suas ações cada vez mais rápidas e certeiras. Ao final, a imagem se faz presente, revelando, além de sua totalidade, os detalhes camuflados pela desintegração inicial, mesmo que não se tenha à disposição todas as peças.

Se pensarmos o presente estudo como o ato de construir a imagem ou o significado das CNs a partir de fragmentos soltos no tempo e no espaço, podemos aproximá-lo da fórmula do quebra-cabeça; porém, sem a ideia da imagem final a ser formada. As peças desse jogo assumem o caráter de fatos, dados e relatos que são disponibilizados por meio de pesquisas, análises e levantamentos. O jogador se transforma em pesquisador. Diferentemente da racionalidade colocada no quebra-cabeça, com número exato de peças e local específico para cada uma, a pesquisa se depara com incertezas, variações e imprecisões impostas pelos materiais encontrados. 
Nos estudos teóricos, um mesmo objeto pode ser construído em várias versões, como Manfredo Tafuri pontuou na introdução de seu livro La esfera y el laberinto (1984). A multiplicidade de fatos acolhidos por um intérprete pode ser agrupada conforme o repertório individual e o contexto (espacial e temporal) onde este se situa. Cada intérprete será responsável pela criação de um objeto único, porém efêmero, que será reformulado pelas variações temporais, pelo acréscimo de peças recém-descobertas e pelas diferentes manipulações realizadas por outros agentes. Sendo assim, a diversidade de resultados proporciona uma construção teórica que, por sobreposições e contraposições, tende a enriquecer a apreensão de um mesmo objeto.

Desse modo, pretendo contribuir para a urbanística brasileira ao somar esta pesquisa a outras do gênero. Com o objetivo central de construir os parâmetros necessários para a conceituação de CNs, por análises históricas, discussões conceituais e estudos de casos, esta pesquisa foi buscar as peças necessárias para a construção desta versão de um quebra-cabeça provisório. A manipulação da documentação levantada no Brasil e no exterior, ${ }^{3}$ que, embora tenha sistematizado determinado número de peças, pode ter deixado outras de fora e, num novo desdobramento, poderão ser encaixadas, dando ao objeto analisado uma nova configuração.

Assim é Cidades novas, um estudo sistemático, generalista, contextual, pessoal e efêmero. Um trabalho constituído na história do urbanismo, tendo como linha condutora dezenas de exemplares de CNs.

Lançar mão da história para compreender as CNs sob o ponto de vista urbanístico permite-nos entender sua configuração atual, criticá-las e projetar seu desenvolvimento a partir de um conhecimento contemporâneo. A pesquisa histórica não se restringe apenas em entender o processo de desenvolvimento de uma cidade, mas pode trazer à tona exemplos urbanísticos que nos auxiliam em seu planejamento.

Saliento que, embora uma CN tenha um marco temporal preciso - sua fundação -, isso não significa que sua história se inicie somente a partir desse ponto. Um plano

3 Acessada em pesquisa no Centre de Documentation de l’Urbanisme - CDU, em La Defénse (França), e nas bibliotecas do Istituto Universitario di Architettura di Venezia (Itália). 
urbano é a expressão de toda a história de uma cidade e não o flash do momento de sua criação ou os frames durante sua evolução. Com base nos pensamentos de Fernand Braudel, em sua obra Écrits sur l'histoire (1969), a história das cidades deve ser interpretada não como um episódio eventual, mas como um episódio de longa duração. A cidade sem passado é irreal, mesmo tendo sido gerada num curto espaço de tempo. Sabe-se que, para qualquer nascimento, existe um estágio fetal e todos os antecedentes que levaram à sua concepção: desejo, função, escolha do sítio etc. Nossa busca, portanto, irá preceder a materialidade física, encontrando vestígios - desejos e necessidades - que levaram à sua criação.

Quanto ao período estudado, iremos transitar dos primeiros núcleos urbanos planejados na história, o que nos remete à Antiguidade, até os exemplares mais recentes - diferentemente da visão limitada de Claude Chaline, em seu livro Les villes nouvelles dans le monde (1985), que situa a origem das CNs na teoria formulada pelo inglês Ebenezer Howard em suas cidades-jardins de amanhã (1898). Também não iremos nos ater a uma narração linear cronológica dos fatos urbanos. ${ }^{4}$ Não se trata, pois, de uma exposição histórica contínua do urbanismo de CNs. Os casos aparecerão pinçados de um determinado momento histórico e conforme a necessidade de materializar uma ideia, um conceito, um tipo urbanístico. ${ }^{5}$ Enfim, um estudo histórico guiado pelo estudo urbanístico.

Ao analisar o espaço físico das cidades, emergem, dos planos, detalhes reveladores: diferenças, oposições, rupturas. São figuras, são desenhos, são peças de um

4 Como nos clássicos: L'urbanistica e l'avvenire della città, de Giuseppe Samonà (1959); The city in history, de Lewis Mumford (1961); L'urbanisme, utopies et réalités, de Françoise Choay (1965); Evolução urbana no Brasil (1500/1720), de Nestor Goulart Reis Filho (1968); Storia dela Città, de Leonardo Benevolo (1976); History of urban form, de Anthony Morris (1979); Cidade brasileira, de Murillo Marx (1980); Historia del urbanismo, de Paolo Sica (1981); e Cities of tomorrow, de Peter Hall (1988); The seduction of place, de Joseph Rykwert (2004); e Storia dela città, de Donatella Calabi (2001 e 2005).

5 Tal qual fizeram: Carlo Aymonino em El significado de las ciudades (1981); Spiro Kostof em The city shaped (1991); Philippe Panerai em Analyse urbaine (1999); Maria Cristina da Silva Leme em Urbanismo no Brasil, 1895 - 1965 (1999); José María Ordeig Corsini em Diseño urbano y pensamiento contemporáneo (2004); Pedro Paulino Guimarães em Configuração urbana - evolução, avaliação, planejamento e urbanização (2004); entre outros. 
quebra-cabeça que nos permitem, parafraseando Castex et al. (1980, p. 3), recortar os índices, de um conhecimento adquirido, de uma capacidade de reconhecer as entidades que já vimos aplicadas em outros lugares, agrupá-las, opô-las, de modo a clarear uma questão, a produzir um senso, a ordenar simplesmente os fatos.

No anseio de compreender uma cidade antiga e, por exemplo, o caso particular de uma cidade criada ex nihilo - do nada -, o emprego da análise urbanística é indispensável. Essa análise começa por examinar o sítio, o local exato onde se fez a implantação inicial, e a situação, a posição da cidade em sua região. Posteriormente, passa-se à análise do tecido urbano e da relação entre o parcelamento e a via, a importância ou a ausência de espaços públicos etc.

O estudo da forma urbana nos coloca frente a frente com os diferentes tipos de traçado e tecido adotados conforme o desejo, a necessidade, o sítio, o repertório do projetista à época. Consoante a trabalhos referenciais sobre morfologia urbana, ${ }^{6}$ intento, sempre que possível, estabelecer uma relação entre a configuração do traçado das CNs e os motivos de sua adoção, geralmente interligados a um dos parâmetros que compõem as CNs.

Diante dos instrumentos, manuais e procedimentos postos, cabe agora revelar ao leitor a estrutura desta obra a fim de posicioná-lo na jornada a ser empreitada.

Como auxílio a esta expedição, estruturei um roteiro da jornada por este livro com uma estação de partida, uma conexão e seis paradas, cada qual introduzida por uma ou um conjunto de CNs brasileiras, escolhidas por afinidade com os temas abordados e pinçadas da história republicana brasileira. Uma estação de partida, uma conexão mais teórica - contextualização e conceituação - e seis paradas mais ilustrativas - atributos inerentes às CNs -, visando a facilitar o entendimento sobre a teorização de CNs.

6 Sobretudo: À propos de la morphologie urbaine, de Françoise Choay e Pierre Merlin (1986); A cidade como um jogo de cartas, de Carlos Nelson Ferreira dos Santos (1988); Introdução ao desenho urbano no processo de planejamento, de Vicente Del Rio (1990); La qualité de la forme urbaine: problématique et enjeux, de Albert Levy (1992); Morfologia urbana e desenho da cidade, de José M. Ressano Garcia Lamas (1993); e Analyse urbaine, de Philippe Panerai (1999). 
Na estação de partida - contexto -, procuro posicionar as CNs no urbanismo, distinguindo-as de outros produtos urbanos. Também apresento o caráter utópico que envolve o objeto em foco e a possibilidade de transformar sonho em realidade por meio da idealização e da criação. Já direcionando os estudos, na conexão dou atenção aos conceitos que compõem esse fenômeno urbano. A partir de uma revisão na literatura sobre os já existentes e a discussão sobre as variações terminológicas utilizadas, realizo a minha própria definição, entendendo CNs como um corpo formado por partes diversas, porém afins.

Percurso inicial cumprido, foco, em cada parada, da primeira à sexta, os seis atributos inerentes às CNs. Inicio pelo capítulo 1 - Desejo em se criar uma CN e os agentes envolvidos, que é interligado ao capítulo 2 - Necessidade de sua criação e a função preliminar para qual foi idealizada. Em seguida, passo ao capítulo 3 - Local e a escolha do sítio e sua posição estratégica, ao capítulo 4 Profissional e o envolvimento de projetistas de formação diversas, ao capítulo 5 - Projeto implantado e suas formas: o traçado e o tecido e, finalmente, chego ao capítulo 6 - Tempo peculiar a essas cidades.

É por esse roteiro, ilustrado a partir de algumas imagens selecionadas da tese - preciosa e delicada arte feita pela arquiteta e urbanista Arielle Cristina Martins -, que pretendo guiá-los, da estação de partida, com conexão e paradas estratégicas, a fim de refletir e questionar os pensamentos, os conceitos, as ideias, visando à formulação de uma proposta teórica sobre CNs. 


$$
y
$$




\section{Cidades novas em seu contexto}

Estação de partida: Belo Horizonte, Minas Gerais.

Na última década do século XIX, nasce na região das Minas Gerais uma nova cidade: Belo Horizonte. Uma decisão político-econômica que transferiu a sede da capital mineira de Ouro Preto para o sítio na Serra do Curral, escolhido dentre outras quatro possibilidades mapeadas ao longo de dois anos de levantamento por uma comissão de técnicos especialistas. Uma decisão envolta por ideais - positivista e utópico - e permeada por um caráter simbólico: o de "expressar o novo Brasil que se pretendia construir com a República” (LEME, 2005, p. 223).

O projeto da nova capital teve início em 1893. A convite do governador Afonso Augusto Moreira Pena, o engenheiro civil Aarão Leal de Carvalho Reis (1853-1936) chefiou a Comissão Construtora da Nova Capital, com a qual colaboraram outros engenheiros formados na Politécnica do Rio de Janeiro, além de arquitetos-projetistas e artistas de renome internacional. Uma fase considerada por Berenice M. Guimarães (1996, p. 127) como “centralizadora, cientificista e utópica de construção da cidade”. Aarão Reis permaneceu somente até maio de 1895, quando foi substituído pelo engenheiro Francisco de Paula Bicalho (18471919), responsável pela condução da obra até a inauguração da cidade em 12 de dezembro de 1897.

Aarão Reis era engajado em movimentos da época, como o abolicionismo e o republicanismo, mas foi no positivismo, pelo viés filosófico da teoria, que pautou sua obra-prima. ${ }^{1}$ Ao recorrer à ciência como uma fórmula para solucionar questões humanas da época, o engenheiro idealizou o plano de Belo Horizonte a partir de

Antes de Belo Horizonte, há informações de que o engenheiro paraense havia aplicado seu conhecimento técnico no plano urbanístico de Soure, na Ilha do Marajó, no estado do Pará. 
problemas tecnicistas, como o de infraestrutura, deixando para segundo plano os aspectos de embelezamento.

A área urbana é composta por duas malhas quadriculadas - uma conformada por vias de 20 metros de largura a cada 120 metros, a outra com vias de 35 metros de largura a cada 800 metros -, sobrepostas a 45 graus, à semelhança dos planos de Washington (1791), Barcelona (1855) e La Plata (1882). Tal sobreposição possibilitou o surgimento de pattes-d'oie ou tridentes, cruzamentos de ruas e avenidas, resultando numa série de pontos perspécticos, geralmente ocupados por edifícios de importância cívica ou artística, aos moldes do urbanismo barroco de Versalhes (1664), de Karlsruhe (1715) ou da Paris haussmanniana (1851). A setorização de funções abrangia áreas residenciais (com tipologias diferentes), administrativas e de serviços. Mas as zonas comerciais e industrial não receberam a mesma atenção. Um grande parque municipal (800 por 800 metros), delineado por um paisagismo pitoresco, completou o esquema. A zona suburbana foi separada da urbana por uma avenida de contorno e dividida em superquadras de 250 por 250 metros para abrigar pequenas propriedades rurais, cemitério, estação de tratamento de esgoto, matadouro, reservatórios d’água etc. Após a zona suburbana, estabeleceu-se a rural e suas grandes propriedades agrícolas, responsáveis por abastecer a demanda alimentícia da nova capital. Desse modo, essas duas zonas periféricas criaram um cinturão verde de modo a trazer o campo para a nova capital, bem como conter seu crescimento.

Essa estrutura geral antecipou, em alguns anos, a proposta semelhante de Ebenezer Howard para a sua cidade-jardim de 1898. Todavia, seu projeto - previsto para 30 mil habitantes e com perspectivas de chegar a 200 mil com as três zonas - foi concebido mesmo antes da escolha do sítio, gerando, após a construção, incongruências entre o traçado idealizado e a topografia irregular existente. 
Cidades novas em seu contexto

Figura 2: Belo Horizonte

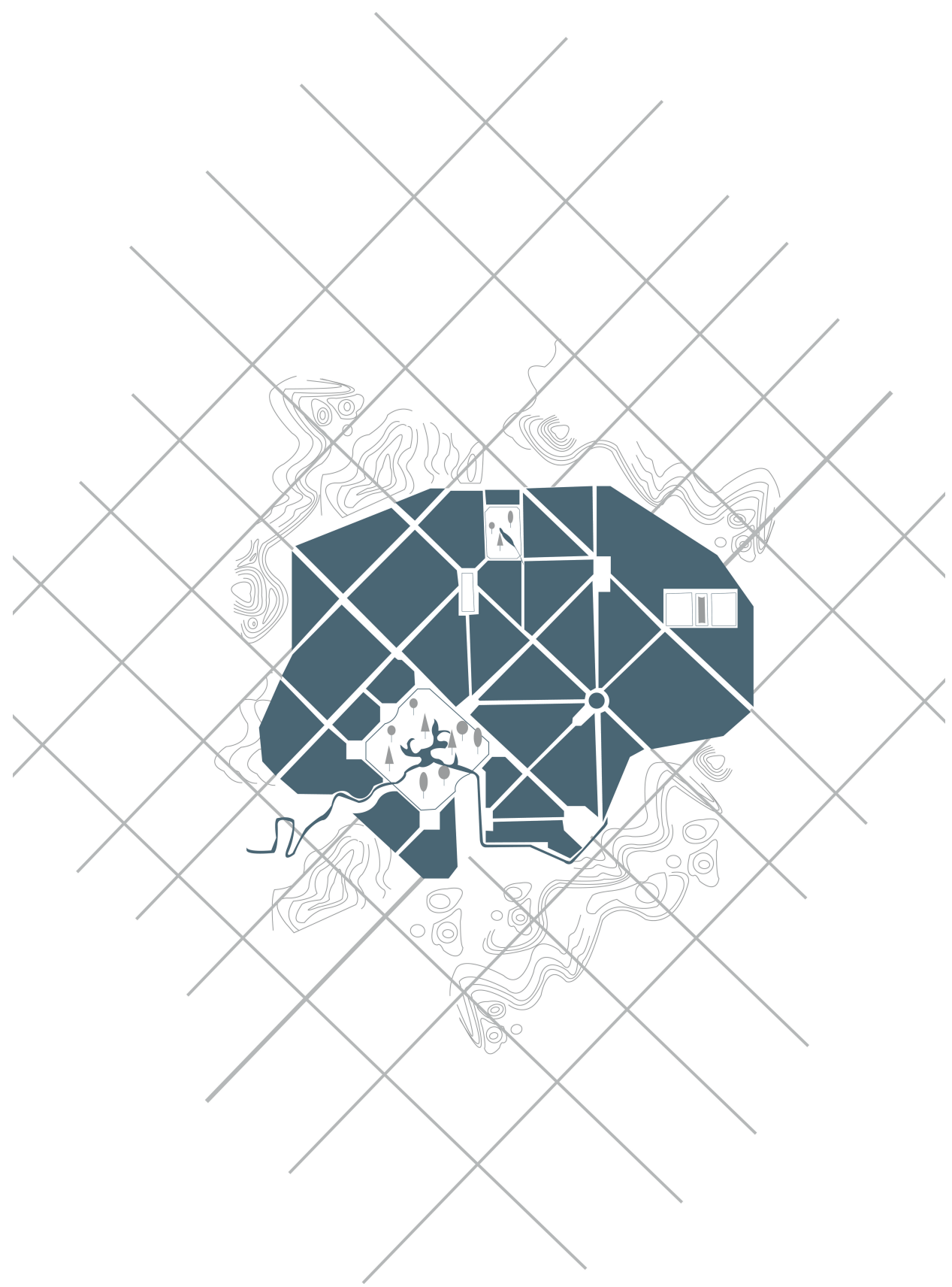


Belo Horizonte foi a materialização de um planejamento científico e racional, “a concretização da primeira utopia urbana brasileira” (GUIMARÃES, 1996, p. 123) na tradição socialista do século XIX. Originalidade à parte, o caráter utópico perceptível no plano de Aarão Reis foi resultado de sua intenção em construir um “protótipo de cidade”, destinado a criar uma sociedade melhor mediante uma nova ciência - o urbanismo - e sob uma nova forma de governo - o republicano. Para Reis, o urbanismo podia tirar proveito de todas as inovações tecnológicas disponíveis para fomentar melhorias sociais e conter as condições caóticas geradas pela industrialização que se iniciava em território nacional. O espaço urbano da nova capital deveria refletir e representar o poder executivo pela monumentalidade e pela organização da sociedade mediante uma convivência harmoniosa entre as diferentes classes sociais.

Positivistas e utópicos, os ideais de Belo Horizonte são aqui introduzidos como trampolim para discutirmos o contexto no qual se insere a temática cidades novas. Em consulta ao Dicionário Houaiss da Língua Portuguesa, contexto, do latim contextus, significa "a inter-relação de circunstâncias que acompanham um fato ou uma situação”. Considerando CNs como um fato, devemos, inicialmente, compreender as circunstâncias que as envolvem. Para isso, selecionei dois trajetos: primeiro, situar CNs enquanto um produto do urbanismo; segundo, revelar o caráter utópico que muitos de seus exemplares, ou os mais significativos na história das cidades, contêm. Duas circunstâncias que nos ajudarão a compreender melhor o universo das CNs.

\section{Cidades novas como um tipo do urbanismo}

Assim como Belo Horizonte, a disciplina urbanismo tem suas raízes no positivismo do século XIX. Foi Ildefons Cerdà i Sunyer (1815-1876), engenheiro-arquiteto espanhol idealizador do plano para a nova Barcelona (1855-1875), que se apropriou da palavra urbs para designar a ciência de organização espacial das cidades, o Urbanismo - termo que não deve ser confundido com seu homônimo, 
que se refere à acepção corrente na arte de desenhar as cidades e seus monumentos, presente desde a origem das cidades (PENNA, 1958).

Ao tornar público seu tratado Teoría general de la urbanización em 1867, Cerdà acreditava, pela primeira vez na história, ter dado status científico à criação e ao planejamento das cidades. Para ele, caberia ao urbanista verificar as regras e as leis contidas nas cidades espontâneas, enquadrá-las em teorias gerais e aplicá-las na concepção e organização de novos espaços.

Historicamente, não há conhecimento de uma sociedade cuja produção do espaço construído tenha surgido de uma disciplina autônoma, inclusive no Renascimento (CHOAY; MERLIN, 2005). Na Antiguidade e no Medievo, a organização do espaço urbano resultava do funcionamento de algumas práticas sociais, em particular a religiosa e a política, cuja permanência histórica teve por efeito constituí-las em padrões (tipos) reproduzidos ao fio do tempo. Acrescentam-se, ainda, como possíveis causas: textos de origem sagrada, produzindo na China cidades como expressão do universo; assentamentos-modelo reproduzidos no decorrer de processos colonizadores da Grécia e do Império Romano; ou propostas originais concebidas para fins precisos, como Bagdá, pela vontade de um príncipe.

Um sopro de mudança nesse processo foi dado na Itália do século XV, quando Leon Battista Alberti (1404-1472) escreveu De re Adificatoria (1443-52) - um tratado de arquitetura oferecido ao papa Nicolas V e publicado após sua morte, em 1485. Para Alberti, a arte de edificar era efetivamente uma disciplina teórica e aplicada, uma disciplina autônoma. A partir daí, uma vez em posse das regras e dos princípios estabelecidos pelo genovês, o arquiteto se tornou o grande organizador do espaço. Cabia a ele estruturar e edificar o quadro da vida humana, desde a paisagem rural, as estradas e os portos, até as cidades, seus jardins, seus planos e suas edificações. Portanto, poderíamos afirmar que Alberti antecipou em quatro séculos a ideia de autonomia e o campo de atuação propostos por Cerdà. Poderíamos... se não levássemos em consideração os contextos ideológico-temporais diferentes. Alberti constrói sua ideia num período pré-Revolução Industrial, em que 
a ciência moderna ainda não existia e o modelo de produção industrial ainda não havia transformado a sociedade urbana e o seu espaço. Na proposição albertiana, identificamos apenas uma visão estética de criação e planejamento urbano - a arte de embelezar as cidades -, que permeará o Renascimento e o Barroco e que, para o conjunto dos teóricos urbanistas pós-Revolução Industrial, salvo algumas exceções, como Camillo Sitte, não passaria de algo secundário.

O pensamento cerdaniano vem da Revolução Industrial e de seus efeitos imediatos no espaço urbano, de uma tradição utopista e positivista do século XIX, além da experiência espanhola em implantar CNs em terras colonizadas. Cerdà testemunhou o progresso de novas disciplinas, em particular da biologia e da história, das quais emprestou paradigmas e dados para postular uma ciência universal de planejamento. Trata-se, portanto, da primeira ocorrência de um gênero textual específico que os estudiosos franceses Françoise Choay e Pierre Merlin (2005, p. 914) nomeiam de "teoria do urbanismo”, e que, até os anos 1960, foi seguida por uma linha ininterrupta de ensaios similares.

Arturo Soria y Mata e sua Cidade linear (1882), Camillo Sitte e sua Cidade artística (1889), Ebenezer Howard e sua Cidade-jardim (1898), Tony Garnier e sua Cidade industrial (1917), Frank Lloyd Wright e sua Cidade evanescente (1932), Le Corbusier e sua Cidade modernista (1933), entre outros, propunham a organização espacial da cidade sob a forma de teoria, com pretensão científica e apresentada em modulações originais.

Todavia, durante o século XX, o urbanismo sai do domínio quase exclusivo de engenheiros e arquitetos para se tornar campo de estudo de outras ciências. Geógrafos, historiadores, economistas, antropólogos, sociólogos, advogados, psicólogos etc. assumem a tarefa de atribuir métodos inéditos de análise e diagnóstico ao espaço urbano, cabendo ao arquiteto-urbanista trabalhar, especificamente, sobre teorias normativas da cidade ou com projetos urbanísticos. A urbanización de Cerdà, originalmente singular e coesa, ganha, assim, outros sentidos, como: "história da 
urbanização, estudo da ecologia urbana, análise do funcionamento de sistemas urbanos” (AHTIK, 1969, p. 366, tradução nossa). ${ }^{2}$

Independentemente de tal transformação, o urbanismo se consolida e se disciplina no século XX, configurando-se como cátedra em universidades, tornando-se campo de atuação de vários profissionais e metamorfoseando-se em designações variadas.

Se, em países de língua latina, ou mesmo na Alemanha, o urbanismo recebe apenas um único termo sintetizador: urbanismo em espanhol, urbanismo ou urbanistica em italiano, urbanisme em francês, Städtebau em alemão, nos países anglo-saxônicos foi atrelado a um conjunto de locuções, como: civic design, town planning, city planning, urban planning, townscape, urban design, sendo urbanism apenas recentemente empregado nos Estados Unidos da América.

Segundo diferentes conceituações, o urbanismo pode ser, alternativamente: "a mais bela, a mais completa das artes, o lugar do conflito e da simbiose entre o gênio criador e as necessidades da multidão” (DELOUVRIER apud TILLIETTE, 1985, p. 13); “uma técnica social [com função de] adequar o espaço físico às necessidades e à dignidade da moradia humana e a todas as aspirações comunitárias” (BAYER apud GUIMARÃES, 2004, p. 2); “o conjunto de disciplinas científicas e artísticas que estudam a problemática da menor unidade territorial, que administrativamente tem por sede uma cidade” (FERRARI, 2004, p. 370); “um estilo de vida [ou] o conjunto das ciências que estudam o urbano” (VILLAÇA, 1999, p. 180); ou, pela visão reducionista, “um subconjunto do planejamento urbano”. (SOUZA, 2001, p. 58).

Seja qual for a definição ao fio da história - arte, técnica e/ou ciência da organização espacial dos estabelecimentos urbanos -, considero o urbanismo, aos moldes do positivismo, como uma “casa de muitos compartimentos” (CARVALHO apud GUIMARÃES, 1996, p. 126). Compartimentos que podem ser separados em: elementos, espécies, modelos, táxons ou tipos, como fizeram outras ciências contemporâneas (biologia, física, química, história etc.), a fim de disciplinar, arranjar,

2 “[...] histoire de l'urbanisation, étude de l'écologie urbaine, analyse du fonctionnement des systèmes urbaines [...]." 
ordenar ou organizar a "casa”. Uma organização de que me aproprio, articulo e emprego nesta obra, visando a auxiliar sua compreensão.

Sinteticamente, além do conhecimento, da reflexão, do saber científico e da arte da criação (sempre presentes no universo urbanístico), decomponho o urbanismo em dois compartimentos distintos: prática e produto, possuindo cada um deles seus tipos específicos.

A prática no urbanismo corresponde às atividades desempenhadas por profissionais da área com o objetivo de atender a uma determinada demanda empreitada pelo poder público e/ou privado, visando à melhoria das condições de vida do morador (ou grupo de moradores) de uma cidade ou região urbanizada. Dentre as práticas existentes, cito: projeto, plano, proposta, traçado, planejamento, embelezamento, melhoramento, paisagismo, desenho, reforma, preservação, intervenção etc.

Já o produto seria o resultado, teórico ou físico, de tais ações urbanísticas, como classificaram o sociólogo Peter Willmott (apud CLAPSON, 1998) e o urbanista Flávio Villaça (1999). O primeiro identifica como produto: os subúrbios periféricos, as cidades novas, as cidades expandidas e o redesenvolvimento de áreas centrais; o segundo amplia o escopo, reconhecendo, além das CNs: os planos de melhoramentos e embelezamento, o planejamento urbano stricto sensu, o zoneamento, o urbanismo sanitarista, os planos de infraestrutura urbana. Enriqueço a lista com: as vilas operárias, os conjuntos habitacionais, a reforma de áreas portuárias, os planos viários, as teorias urbanas, os planos gerais, os planos diretores e os planos de desenvolvimento estratégico.

O arquiteto Guy Burgel, em palestra ministrada no Conservatoire National des Arts et Métiers em Paris (5 de junho de 2008), salientou que há duas possíveis soluções para os problemas urbanos: reconstruir a cidade sobre a cidade (prática), por meio de planos de reestruturação, renovação etc. (produtos); ou criar (prática) cidades alhures (produtos). Prática e produto, compartimentos que nos auxiliam a enquadrar CNs como um tipo produzido pelo urbanismo. Um sistema classificatório que pode ser sequenciado, detectando, no conjunto, seus diferentes tipos: pela função original (administrativa, colonizadora, turística etc.), pelo traçado (em malha, 
radioconcêntrico, linear, modular etc.), pela filiação teórica (albertiana, modernista, howardiana etc.) ou por quaisquer outras possibilidades que possam surgir.

Ao evocar o caso de Belo Horizonte - um empreendimento público, planejado para ser a nova capital de Minas Gerais, implantado estrategicamente sobre a Serra do Curral, projetado pelo engenheiro Aarão Reis e fundado após quatro anos de sua concepção -, posso afirmar que se trata de um tipo de CN classificável ou como uma CN administrativa ou como uma CN em malha. Método igualmente válido para Barcelona: CN de expansão ou CN cerdaniana. CNs distintas, mas ambas consideradas CNs, um tipo do urbanismo.

Portanto, ao contextualizar as CNs na ciência urbanística, destacando-as do universo de produções existentes, abro caminho para trabalhar seus inúmeros aspectos qualificativos, como o conceito de cidade ideal.

\section{Cidades novas como ideais: da utopia à realidade}

Belo Horizonte foi um ideal de Aarão Reis posto em prática em fins do século XIX. Uma utopia que se tornou realidade graças às conjunturas propícias daquele momento. Como a capital mineira, outras cidades ideais surgiram a partir de propostas inovadoras, consideradas por muitos devaneios de seus criadores; já outras permaneceram fictícias, como utopias. Realizadas ou utópicas, tais cidades ou ideais compõem o universo das CNs.

Em Storia dell’Utopia (1969), o sociólogo e historiador norte-americano Lewis Mumford define utopia como:

[...] o estágio último da loucura humana ou da esperança humana: inúteis sonhos de perfeição em uma Terra do Nunca, um país que não existirá, ou uma pura tentativa racional de reconstruir o ambiente humano, suas instituições e até a imperfeição de sua 
natureza, com propósito de aumentar a oportunidade na vida a cada dia. (MUMFORD, 1969, p. 1, tradução nossa). ${ }^{3}$

Loucura ou esperança, indícios revelam que o termo utopia foi forjado, originalmente, pelo escritor inglês Thomas More (1478-1535), em sua obra homônima de 1516, a partir de raízes gregas. Surgiu do substantivo tópos (lugar) e duas partículas, o prefixo eu (boa qualidade) e ou (nenhum), sendo também utilizado pela sua contração $u$. Significa, respectivamente, o espaço bom (eutopia) e o espaço que não existe (utopia). ${ }^{4}$

Contudo, as criações de uma sociedade perfeita habitando uma cidade-modelo datam de muito antes do século XVI. Da República (384-377 a.C.) de Platão ou do Monte Athos (século $1^{\circ}$ d.C.) de Vitrúvio às propostas de cidades em grandes estruturas da segunda metade do século XX - Brasília de Rino Levi (1957), Tóquio de Kenzo Tange (1960) e Walking cities de Ron Herron (1964) -, as cidades ideais são símbolo de uma busca pela felicidade original perdida, perseguida desde as tradições bíblicas (Éden, a terra prometida). ${ }^{5}$

Tais proposições sempre alimentaram a humanidade e ocuparam o imaginário de um grande número de filósofos, escritores e historiadores. Em referência a Anatole France, sem as utopias, os homens estariam ainda vivendo em cavernas, miseráveis e nus. Foram os utópicos que traçaram as linhas das primeiras cidades (apud BERNERI, 1950, s/p). Saídas de sonhos generosos, esses intentos

3 “[...] lo stadio ultimo dell'umana follia o dell'umana speranza: inutili sogni di perfezione in uma Never-Never Land, il paese che non esisterà, oppure tentativi razionali di ricostruire l'ambiente umano, le sue istituzioni e perfino le imperfezioni dela sua natura, allo scopo di aumentar ele opportunità nella vita di tutti i giorni.”

4 Há ainda a Kakotopia (lugar ruim), termo formulado pelo biólogo, sociólogo e planejador urbano escocês Patrick Geddes (1854-1932), em sua obra Cities in evolution: an introduction to the town-planning movement (1915), para referir-se à cidade industrial e seus "bairros pobres, semi pobres e muito pobres” (GEDDES, 1994, p. 8).

5 A continuidade da dimensão suprema na utopia pode ser verificada nas pinturas medievais ou renascentistas, que transformavam o espectador em olho celeste (deuses) ao lhe possibilitar visualizar a cidade de um ponto de vista (voo de pássaro) que jamais existira até então. 
tornaram-se realidades benéficas. Utopia, segundo o escritor francês, seria o princípio de todo o progresso, um ensaio para um futuro melhor.

Contrário à ideia da utopia platônica, Anatole France indica a realidade como único caminho para uma vida melhor. Para ele, Platão criou um discurso de utopia que aprisionou todos os utopistas posteriores. Sem tirar-lhe os méritos de gênio, considera o filósofo como "um protofascista”, que acreditava no papel de comando da elite, na autarquia, no uso da mentira para governar, no militarismo, e em muitos outros métodos. Seguindo o raciocínio, Lewis Mumford (1969) acredita que a maioria dos utopistas clássicos apresentava tendências ditatoriais, tentando impor às múltiplas atividades humanas e ao jogo de interesse da sociedade uma disciplina monolítica. ${ }^{6}$

Lewis Mumford irá pensar a utopia como algo oposto ao espírito unilateral, partidário, especializado. Para o autor, quem segue o método utópico deve considerar a vida no presente e em todos os pontos de vista, ou seja, “como um conjunto interrelacionado [...] como um órgão junto de partes suscetíveis a melhor organização, com as quais é importante manter o equilíbrio” (MUMFORD, 1969, p. 4, tradução nossa). ${ }^{7}$

Românticas ou realistas, as definições encontradas na literatura também nos permitem estabelecer um entendimento da utopia a partir dos seguintes aspectos: temporal, político-econômico-social e físico.

Pelo viés temporal, a busca nostálgica por um passado perdido e o anseio por um futuro inatingível fizeram da utopia uma negação do presente. Ciente disso, Giulio Carlo Argan afirma:

6 Como exemplo, cita-se a proposta do ditador italiano Benedito Mussolini (1883-1945) para a Esposizione Universale di Roma (EUR) de 1942: um núcleo urbano iniciado em 1939, projetado pelo arquiteto Marcello Piacentini e equipe, alocado na periferia da capital italiana e marcado por uma arquitetura rígida, simétrica e homogênea - personificação, nesse caso, do poder e glória de um regime totalitário.

7 “[...] come um tutto interrelazionato [...] come um orgânico insieme di parti suscettibile di migliore organizzazione, di cui è importante mantenere l'equilibrio [...].” 
O que atrai, no passado e no futuro, é justamente o não estar "presente”. É até mesmo possível reunir as duas categorias aparentemente contraditórias em uma só e considerar tudo como utopia: entendida não tanto como prefiguração de um tempo melhor, mas como desgosto e impossibilidade de viver no atual. (apud PESSOA, 2006, p. 101).

Na história, as utopias aparecem mais regularmente em períodos de transição e em épocas de grandes incertezas. Exemplo disso são as proposições dos “socialistas utópicos” nos séculos XVIII e XIX , como saídas alternativas para a florescente cidade industrial e suas adversidades. Chamados de "progressistas” por Françoise Choay (1997), esses pensadores acreditavam, com base na enorme adaptabilidade da sociedade, que bastava renegar o passado para se obter a chave de um futuro melhor, previsto racionalmente em todos os aspectos. Foi assim quando o escritor francês Etienne Cabet (1788-1856) criou, em 1840, a cidade de Icara, capital de um Estado fictício: Icaria, descrita por ele em seu livro Voyage en Icarie. Ou quando o médico inglês Benjamin Ward Richardson (1828-1896) formulou, também em livro, a cidade de Hygeia (1876) - Cidade da Saúde.

Outros criadores evocaram um tipo antigo como referência fundamental em todas as tentativas de remodelação e de reestruturação urbana - os "culturalistas" (CHOAY, 1997). Bandeira hasteada por Camillo Sitte (1843-1903), ao resgatar para sua Cidade artística as características existentes nas cidades medievais, em especial as praças; e pelos filósofos ingleses John Ruskin (1818-1900) e William Morris (1834-1896) que, unidos ao arquiteto Richard Norman Shaw (1831-1912), lideraram o movimento Arts \& Crafts. ${ }^{8}$

8 O Arts \& Crafts (Artes e Ofícios), criado pelos filósofos Ruskin e Morris no século XIX, opunha-se aos modos de trabalho e de produção impostos pela industrialização, primando os estudos históricos e o artesanato. A base desse Movimento estava não no progresso, mas na cultura, no resgate do caráter social e artesanal da produção e na instituição da arte na vida cotidiana das pessoas. 
Mas, em ambas as vertentes, seja progressista ou culturalista, há um ponto em comum: a rejeição à realidade, nutrida por um sistema político-econômico-social insatisfatório.

Paralelamente ao fator tempo, a crítica ao sistema vigente faz da utopia uma busca pela sociedade ideal, associada às noções de evolução, de perfeição e de progresso. Geralmente, o interesse individual deveria ser substituído pelo coletivo, como um ponto inicial de transformação do mundo. Nesse sentido, o norte-americano Edward Bellamy (1850-1893) futuriza, em seu livro Looking backwards (1888), a cidade de Boston no ano 2000 como uma sociedade centralizada e igualitária, na qual direitos sociais são respeitados e deveres são repartidos com a máquina a serviço do homem (BELLAMY, 1942). Agrupamento social similar ao Falanstério, do francês Charles Fourier (1772-1837): um único edifício ocupado por 1,6 mil pessoas em busca da harmonia universal - uma grande máquina de habitação destinada a criar uma vida comunitária estreitamente integrada.

A fim de atingir o perfeito desenho social, a maioria dos utopistas formula, simultaneamente, um novo habitat e, invariavelmente, uma nova cidade. É como se sociedade e cidade não pudessem ser dissociadas. Assim, o espaço urbano - a materialização do sonho - sempre foi o cenário das utopias, sendo apresentado em diferentes trabalhos: Cidade de Deus, de Santo Agostinho (410 d.C.), Sforzinda, de Antonio Averlino Filarete (1460), Abadia de Thelema, de François Rabelais (1532), Cristianópolis, de Johann Valentin Andreäe (1619), Cidade do Sol, de Tomaso Campanella (1623), Nova Atlântida, de Francis Bacon (1624), Oceana, de James Harrington (1656), Aventuras de Telêmaco, de François de Salignac de La Mothe-Fénelon (1699), Suplemento da viagem a Bougainville, de Denis Diderot (1772), além das propostas pós-Revolução Industrial, como as vilas industriais campestres do geógrafo russo Piotr Alexeevich Kropotkin (1842-1921).

Romanceadas em obras literárias como respostas a uma contrautopia (lugar inabitável) existente, tais criações também materializaram soluções urbanísticas originais, introduzidas em parcelas urbanas ou na totalidade de uma CN. Utópicos, radicais, 


\section{Cidades novas}

inovadores, polêmicos, criticados ou louvados, esses trabalhos tiveram a iniciativa de repensar, de modo revolucionário, a cidade caótica, fosse pelo planejamento urbano segundo as necessidades impostas (por exemplo, as obras do papa Sisto V em Roma, no século XVI, ou as intervenções de Haussmann em Paris do século XIX), fosse pela criação de CNs. Cidades-conceito que, elaboradas por pensadores e reformadores atentos à situação inquietante de uma determinada realidade, provocaram transformações físico-sociais mediante apropriações isoladas ou absolutas no decorrer do tempo.

Nessa direção, a utopia, vista por seu aspecto físico, recebeu atenção especial de Emmanuel Eveno em seu livro Utopies urbaines, de 1998. Para o autor, a utopia urbana é um ato político, cuja finalidade se divide, globalmente, em duas grandes famílias: as "utopias-espelhos” (utopies-miroirs) e as “utopias-projetos” (utopies-projets). A família das "utopias-espelhos” é aquela do mundo inverso - a sutil inversão ótica do espelho -, não destinado a ser real, mas instigador da imaginação. As “utopias-espelhos” representam um modo de expressão política e podem ser um ato de oposição, uma crítica ou uma contestação - ideia compartilhada pelo arquiteto francês Yannis Tsiomis, que define utopia como "uma contra realidade, uma inversão da realidade, termo a termo, uma versão de texto que construa outro espaço que não é inexistente, mas que seja uma inversão do espaço existente” (TSIOMIS, 2006, p. 71).

Por sua vez, a família de “utopias-projetos” se apresenta a partir de dois principais aspectos: as "utopias completas" e os "fragmentos de utopias”. As “utopias completas" repousam sobre um pragmatismo de uma nova fundação, justificado num ato revolucionário para organizar total e completamente uma nova sociedade. São utopias frequentemente associadas ao Renascimento, ao Iluminismo e a algumas CNs das Américas colonizadas. Ilustram esse caso a CN empresarial de Chaux, na França, projetada pelo arquiteto Claude-Nicolas Ledoux (1736-1806) e construída entre 1774 e 1779; e a norte-americana New Harmony, de 1824, planejada por Robert Owen (1771-1858).

Os “fragmentos de utopias” focalizam a temática a partir da dimensão projetiva, tendo os fragmentos o objetivo de assinalar que, no projeto, os princípios revolucionários e de nova fundação social são secundários. Nela, na dimensão 
projetiva, a arquitetura e o urbanismo são os meios mais claros de intervenção. Algo recorrente no século XX, quando o pragmatismo dilui o projeto utópico na tensão que existe entre projeto-decisão-realização, conferindo à utopia um lugar na elaboração do projeto. Essa forma utópica se justifica por sua exemplificação, acomodando experimentações limitadas no espaço urbano, como a Cidade marina de Kiyonori Kikutake, de 1968, e a Cidade sistemática urbano-fabril-agro-florestal na Amazônia, do arquiteto brasileiro Spencer Pupo Nogueira, dos anos 1980.

Figura 3: Cidade Marina

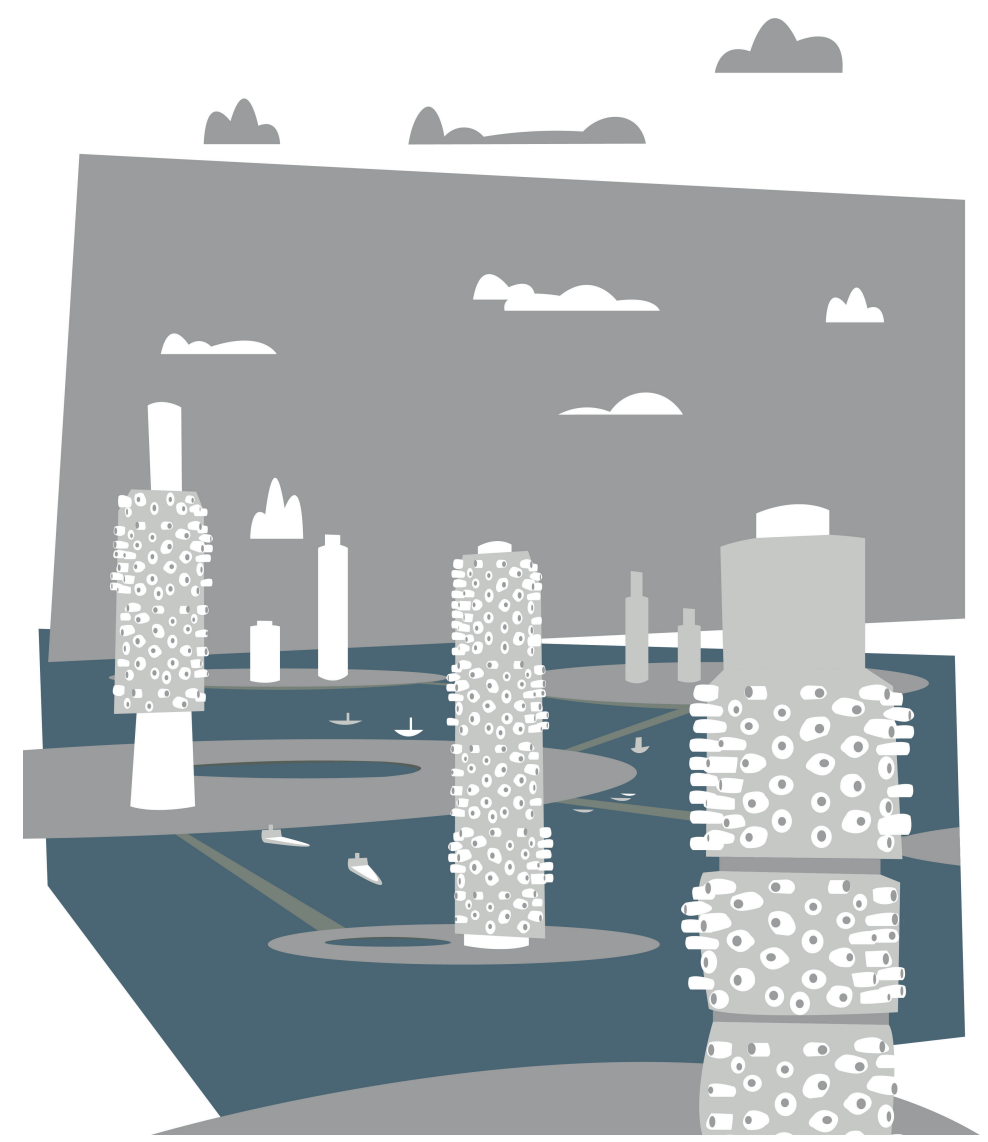


Essa utopia física, urbana e arquitetônica foi fomentada pelas inúmeras teorias originárias dos séculos XIX e XX. Seus genitores - Howard, Soria y Mata, Le Corbusier, Clarence Stein e Henry Wright, Frank Lloyd Wright, Buckminster Fuller, Cedric Price, Yona Friedman, Team X, Archigram, entre outros - foram responsáveis por uma rica produção de tipologias urbanísticas. Como consequência, tivemos a origem de diferentes CNs, idealizadas com o intuito de estabelecer um rumo a seguir, uma bússola colocada à disposição da sociedade.

Tais cidades ideais, assim como vimos no conceito de utopia, recebem diferentes definições. Michel de Certeau (1996) as conceitua a partir de uma tríplice operação: 1) a produção de um espaço próprio; 2) o estabelecimento de um não-tempo ou um sistema sincrônico; e 3) a criação de um sujeito universal e anônimo, que é a própria cidade. Hanno-Walter Kruft (1990) as apropria pela dimensão física: 1) a regularidade da projetação - plano regular - não precisa ser um critério obrigatório; e 2) a necessária correspondência estética entre utopia e forma da cidade ideal pressupõe que deve existir um procedimento reflexivo. Pier Luigi Giordano as coloca como excludentes dos aspectos sociais, obedecendo “apenas a um interesse prioritariamente formal, sem qualquer interesse no substrato humano, apenas com o gosto estético pelo traçado, ainda mais se este tiver por finalidade militar ou política” (GIORDANO, 1962, p. 181, tradução nossa). ${ }^{9}$ Patrick Boucheron (2002) segue o mesmo pragmatismo, considerando-as como uma simples cidade de fundação e tal fundação é, por definição, um gesto político.

De uma definição mais filosófica a outras taxativas e simplistas, as cidades ideais são uma realidade. Ao longo da história, identificamos exemplares que, mesmo não sendo efetivados (conceituais), acabaram por influenciar as práticas urbanísticas posteriores.

Tipos geométricos, simétricos, regulares, pontuados por uma centralidade; tipos fechados delimitados por muralhas, fossos, penhascos ou cinturões verdes;

9 “[...] solo per un interesse principalmente formale, senza alcun interesse per il substrato umano, solo con il gusto estetico del trattino, anche se ha fini militari o politici [...]." 
tipos bidimensionais (traçado) ou tridimensionais (tecido); essas cidades ideais saíram do campo virtual, da utopia, para se tornarem nossas cidades, uma realidade como Belo Horizonte.

Assumo que um mundo sem utopias, sem sonhos, sem CNs seria um mundo inerte, alienante, sufocante; e graças a elas tenho ânimo para continuar em nossa viagem que apenas se inicia. 


$$
y
$$




\section{Cidades novas e seus conceitos}

\section{Conexão: Santos, São Paulo.}

Contemporaneamente ao sonho realizado em terras mineiras, a secular vila portuária de Santos, fundada no litoral paulista em 1545, recebe, pelos preceitos da engenharia sanitarista, um novo plano urbano, um plano de modernização que a transformou em uma nova cidade. Um cenário fervilhante, desenhado a partir das últimas décadas do século XIX, quando a cidade se destacava por sua posição estratégica e, concomitantemente, como o principal porto brasileiro na exportação cafeeira e a porta de entrada para milhares de imigrantes.

O ouro verde, escoado por ferrovias vindas do interior, chegava à cidadela empresarial de Paranapiacaba, ${ }^{1}$ descendo a Serra do Mar até chegar ao porto da Companhia Docas de Santos. Na mão inversa, italianos, poloneses, judeus, alemães, espanhóis, japoneses, árabes e mesmo brasileiros de outras regiões desembarcavam em terra firme, deparando-se com imagens de uma cidade em franco crescimento socioeconômico.

Todavia, era uma paisagem caótica, babélica, espurcícia, sem condições de atender adequadamente ao contingente populacional que ali chegava. Um cenário composto por frequentes surtos epidêmicos e pelo aumento gradativo do déficit

\footnotetext{
Paranapiacaba surgiu em 1867 como uma CN empresarial, empreendida pela The Sao Paulo Railway Company Ltd. e implantada à borda da Serra do Mar. A vila foi criada para abrigar funcionários e respectivos familiares que trabalhavam para a Companhia (de capital inglês) responsável pela administração e funcionamento da linha férrea San Paulo Railway. Assim como nas company towns (cidades empresariais), a vila apresentava uma setorização primária (áreas produtivas e áreas de repouso), ruas largas e pavimentadas com paralelepípedos, infraestrutura básica, habitações isoladas no lote - padronizadas de acordo com o número de moradores (à exceção das casas dos diretores) - e equipamentos sociais voltados para ações culturais e de lazer de seus habitantes. Hoje, a vila é distrito do município de Santo André, no ABC paulista, tombada em 2008 pelo Instituto do Patrimônio Artístico e Histórico Nacional - Iphan.
} 
habitacional, frutos de um crescimento rápido e repentino - a população local saltou de 15 mil habitantes em 1886 para cerca de 50 mil em 1900.

Localizada numa planície peninsular, separada da vila de São Vicente (1532) por elevações naturais, isolada pela baía e pelo canal de Santos, a cidade precisava adequar-se às novas funções às quais estava exposta assim como sanear seus espaços físicos. Um ambiente degradado que demandava, urgentemente, do governo municipal e estadual, ações reparadoras.

As ações visavam, de modo geral, a garantir à cidade condições básicas de infraestrutura: saneamento, energia, transporte público (bonde) e sistema viário adequado. As epidemias que assolavam a saúde pública nesse momento seriam solucionadas com a construção de redes públicas de abastecimento de água e coleta de esgoto da maneira proposta por médicos-higienistas e engenheiros-sanitaristas. As estreitas vias não mais comportavam o tráfego de veículos e pedestres; era necessário discipliná-las e aumentar a capacidade de fluxo mediante projetos para o sistema viário - novo alinhamento para os edifícios; abertura, alargamento e prolongamento de vias; desenho de canteiros centrais etc. Assim, expandir o traçado urbano por meio de planos de saneamento, melhoramentos e extensão, rumo a uma ocupação ordenada da península, foi a solução encontrada.

Segundo José Marques Carriço (2013), as obras de saneamento e melhoramentos começaram com a reforma do cais do porto em 1888, seguida pela construção da primeira rede de esgoto - baseada no sistema de separação parcial, com águas cloacais e pluviais conduzidas por uma mesma rede. Obras sucedidas por planos de saneamento e leis específicas: o plano de $1892,{ }^{2}$ elaborado pelo engenheiro civil

2 Mesmo ano de fundação da CN balneária do Guarujá, vizinha a Santos, primeiro grande plano imobiliário para o lazer realizado no estado de São Paulo e sob a responsabilidade da Companhia Balneária da Ilha de Santo Amaro (REIS FILHO, 1994; MARINO, 2017). O plano urbanístico e arquitetônico coube ao engenheiro civil Elias Fausto Jordão Pacheco (1849-1901). Formado pela Faculdade de Cornell (EUA), Pacheco trabalhou para a Companhia Paulista de Estradas de Ferro e para a Companhia Ituana antes de assumir o plano para o balneário. Tomou como referência os projetos de CNs norte-americanas das regiões pioneiras e de alguns empreendimentos urbanísticos mais sofisticados da região de Rhode Island. Como consequência, verificou-se um núcleo construído sob os moldes da arquitetura e do urbanismo anglo-saxão. Paralela à orla marítima, foram 
porto-riquenho Estevan Antonio Fuertes (1838-1903), então professor de engenharia sanitária na Universidade de Cornell (EUA); o Código de Posturas Municipal e o Código Sanitário Estadual, ambos de 1893; e os planos das comissões: Thomas Cochrane, de 1896, e Alfredo Lisboa, de 1897. Em 1898, foram criadas as repartições de Águas e Esgotos da capital paulista e Técnica de Águas e Esgotos do Estado. No mesmo ano, ambas foram unificadas na repartição de Águas e Esgotos, sob a chefia do engenheiro sanitarista baiano Theodoro Sampaio (1855-1937).

Ademais, o primeiro plano de expansão para Santos surgiu apenas em 1896, encomendado pela Câmara Municipal e atribuído ao engenheiro José Brant de Carvalho (1856-1917). Um plano elementar, no qual o autor expandia até a barra uma malha cardo-decumano (vias no sentido norte-sul e leste-oeste) a partir do antigo núcleo. Partido projetual indicado para um terreno relativamente plano, com quadras regulares pontuadas por praças equidistantes. Nota-se, entretanto, que não houve preocupação em adequar as vias aos caminhos pré-existentes nem diferenciá-las paisagisticamente ou mesmo em considerar os seus aspectos hidrológicos.

Esse conjunto de planos, obras e leis pouco contribuíram para uma solução definitiva. Somente no início do século XX ocorreria uma alteração nesse quadro, com a organização, em 1903, da Comissão de Saneamento do Estado de São Paulo, dirigida, inicialmente, pelo engenheiro José Pereira Rebouças (1856-ignoto). Dois anos mais tarde, o cargo de chefia passa à responsabilidade do engenheiro sanitarista Francisco Saturnino Rodrigues de Brito (1864-1929), nascido no Rio de Janeiro e formado pela mesma Escola Politécnica de Aarão Reis.

Assim como Reis, Saturnino de Brito também foi seguidor dos ideais positivistas, acreditando ser a ciência a solução para os problemas cotidianos. Antes de Santos, o sanitarista já havia aplicado seus conhecimentos técnicos em projetos para: Piracicaba (1893); Belo Horizonte (1894-1895, tendo contato com Aarão Reis);

implantadas, em sequência, uma faixa de jardim e os principais edifícios (Grande Hotel, cassino etc.); perpendicularmente, encontravam-se a linha férrea (ramificação da San Paulo Railway alocada em Santos), a principal via e a igreja. Todos os edifícios, inclusive as 46 casas em estilo Bungalow (chalés), foram projetados e construídos com madeiras importadas do estado da Geórgia, EUA. 
Novo Arrabalde em Vitória (1896); Campinas, Ribeirão Preto, Limeira, Sorocaba e Amparo (entre 1896-1897); Petrópolis (1898); Campos (1902-1903); e outros. Eram estudos higienizadores, visando a sanear as cidades com rede de abastecimento de água e sistemas para coleta de esgotos e drenagem de águas pluviais, usufruindo de novos saberes e novas técnicas construtivas, como, por exemplo, o uso do concreto armado na confecção de canais fechados e abertos.

Paralelamente, podemos relacionar as propostas urbanas de Brito com as teorias formuladas por Camillo Sitte em sua Cidade artística (1889). Embora distantes e vivenciando realidades diferenciadas, ambos defendiam a estética urbana "na concepção organicista da cidade, que [os levava] a privilegiar os chamados planos gerais ou de conjunto” (ANDRADE, 1992, p. 208). Uma maneira de pensar a cidade como um todo, aliada à possibilidade de transformar a cidade em paisagem, seja com ruas e avenidas interrompidas por praças, jardins e monumentos em seus horizontes, seja pela própria configuração das vias desenhadas como parques-lineares - os bulevares.

Enfim, um arcabouço de repertório variado, técnico-artístico, que proporcionou ao plano urbanístico de Santos uma forma ímpar, destacando Saturnino de Brito como um ícone no rol dos urbanistas brasileiros.

Seu envolvimento com a cidade santista, na verdade, iniciou-se em 1898, quando colaborou no planejamento de um sistema de separação absoluta para a rede sanitária (com uma rede para águas cloacais e outra para águas pluviais), incluindo estações elevatórias distritais. Proposta implementada apenas em 1905, ao assumir a Chefia da Comissão de Saneamento, a convite do novo governador do estado de São Paulo, Jorge Tibiriçá Piratininga (1955-1928).

O partido projetual de Saturnino de Brito foi realizar um plano geral para a cidade. Um plano que, diferentemente dos adotados até aquele momento - isolados e compartimentados -, englobasse os planos de saneamento, de melhoramentos e de expansão urbana, levando em consideração elementos já existentes, fossem eles naturais (como topografia e hidrografia) ou artificiais (como caminhos e pequenas estradas). 
A partir dos levantamentos feitos por planos anteriores, Saturnino de Brito tinha em mãos dados suficientes para elaborar um projeto extremamente detalhado. Desde o regime de chuvas, as variações das marés, os pequenos corpos fluviais que cortavam a planície, o acúmulo de águas provenientes das encostas, as curvas de nível, até estudos do solo, todos auxiliaram Brito na elaboração de uma CN modelo sob o ponto de vista ambiental.

Nesse sentido, o engenheiro-sanitarista tirou proveito dos canais abertos, implantados para drenar águas pluviais, servir como via de circulação para pequenas embarcações e constituir uma paisagem pitoresca no cenário urbano, uma vez que, às suas margens, desenharam-se vias com amplas calçadas - mais largas que três metros - e densamente arborizadas (ANDRADE, 1992). Canais de superfície eram naturalmente limpos por ação gravitacional, graças a um sistema de comportas que se abriam com a cheia das marés. A água do mar entrava por essas comportas, misturando-se com a água estanque até os pontos mais distantes da praia, sendo escoada, posteriormente, com a baixa-mar. Um método científico peculiar, aplicado na adaptação do meio natural às necessidades humanas.

Além disso, Saturnino de Brito instalou uma rede subterrânea para abastecer toda a nova cidade com água tratada, bem como uma rede coletora de esgoto, ligada diretamente aos equipamentos sanitários internos dos imóveis. Todo esse aparato infraestrutural foi executado entre 1905 e 1927, contando com 17 quilômetros de canais abertos e 80 quilômetros de rede subterrânea.

Simultaneamente, o parcelamento da expansão urbana foi traçado tendo por influência direta a Washington (1791) de Pierre Charles L’Enfant, como o próprio autor revelou (apud ANDRADE, 1991, p. 60). Distinta da proposta de Brant (1896), a malha reticulada obedeceu à geomorfologia da península, sendo rotacionada em momentos oportunos, apresentando quadras com dimensões variadas e sistema viário hierarquizado. A patte-d'oie foi utilizada para seccionar vias muito longas, criando espaços verdes para lazer e contemplação em seu ponto de coesão. Os lotes ganharam 
novo desenho em relação aos lotes coloniais, caracterizando-se por maior amplitude e recuos frontal e laterais, assegurados por uma legislação específica definida por Brito.

Um plano meticulosamente elaborado e implantado, que, segundo Carlos Roberto M. de Andrade (1991), deu “origem a uma nova cidade com um desenho extremamente moderno para a época, aproximando a paisagem urbana santista daquela das cidades europeias” (ANDRADE, 1991, p. 57).

É inegável, portanto, a importância desse exemplar para a urbanística brasileira. Porém, ele foi aqui inserido com outro propósito: servir como conexão à conceituação de CNs.

A propósito, julgo Santos como uma CN do século XX, apesar de sua fundação datar do século XVI. Uma CN empreendida pelo poder público e projetada por profissionais para atender a um determinado fim. Uma CN cuja área de expansão superou em muito a área da cidade existente, à semelhança dos projetos expansionistas para Nova York (1811), sob a responsabilidade de um comissariado público local; para Barcelona (1855), de Ildefons Cerdà; ${ }^{3}$ para Boa Vista (1944), ${ }^{4}$ do engenheiro civil Darcy Aleixo Derenusson; e para Paulínia (1969), do arquiteto Jorge Wilheim. Vilas ou cidades existentes que foram encapsuladas pela nova trama projetada; que cresceram repentina e ordenadamente; vilas e cidades que se tornaram CNs.

3 Barcelona de Cerdà era seis vezes o tamanho da cidade intramuros (CARRERAS, 1986).

4 Boa Vista, fundada em 1830, é considerada a terceira capital projetada no período republicano, após Belo Horizonte e Goiânia (TREVISAN; FICHER; MATTOS, 2017). Com o desmembramento, em 1943, do estado do Amazonas, originando o Território de Rio Branco (atualmente Roraima), o poder público local escolheu a cidade nortista como sua capital e designou o engenheiro civil Darcy Aleixo Ribeiro Derenusson (1916-2002) para elaborar um plano de urbanização. Este foi iniciado em 1944, sendo aprovado em 1946, e mobilizou uma vasta equipe dos mais conceituados especialistas em urbanismo e infraestrutura urbana. Do projeto, confeccionado numa planta em escala 1:1.000 e empreendido pela Riobras Industrial Ltda., destacam-se o novo centro cívico e suas 12 vias radiais extremamente largas, tendo a avenida principal cem metros de largura. 
Figura 4: Santos

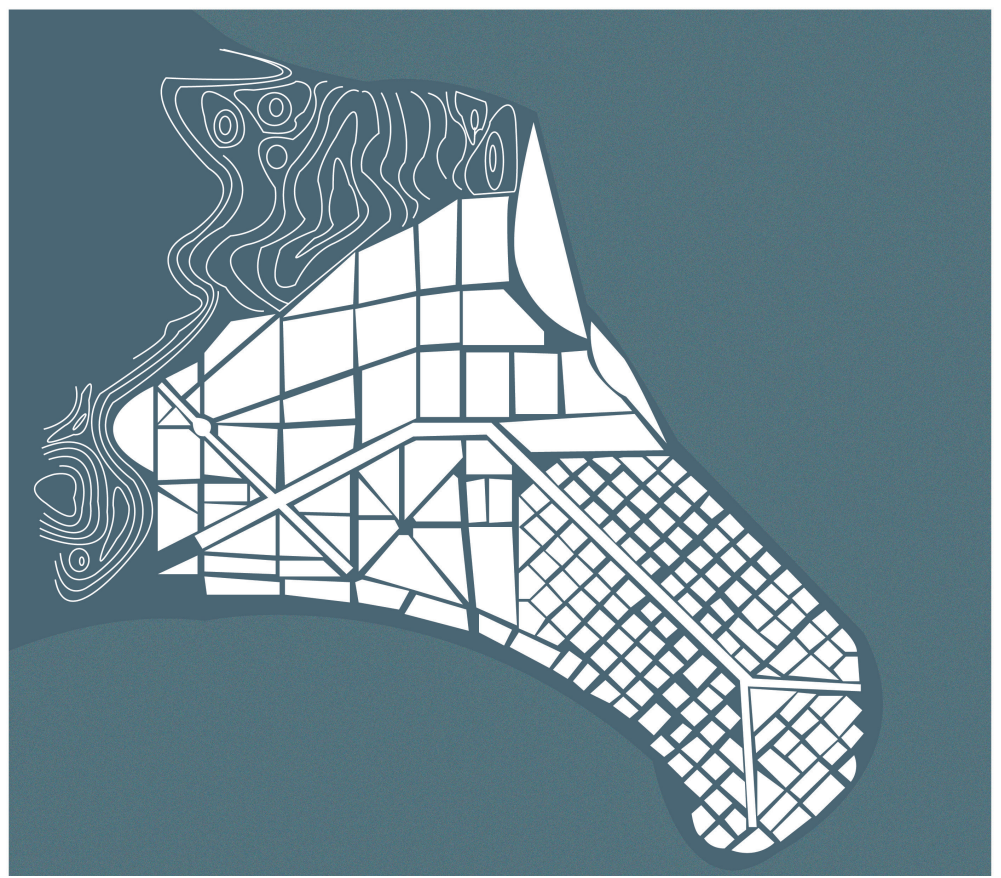

Essa concepção é compartilhada por pesquisadores poloneses, liderados pelo professor Bohdan Jalowiecki (diretor do EUROREG - Centro Europeu de Estudos Regionais e Locais da Universidade de Varsóvia), ao definirem uma CN de expansão como aquela que "foi construída segundo um plano de urbanismo preciso, com um tamanho previsto ao menos dez vezes superior ao núcleo existente” (HAUMONT, 1997a, p. 84, tradução nossa). ${ }^{5}$ Uma definição particular, formulada para auxiliar a identificação de CNs na Polônia.

Esses mesmos estudiosos se interrogaram: "um grande novo bairro, contando com 100 mil habitantes ou mais, construído ao lado de uma antiga cidade, [pode] ser definido como uma cidade nova?” (HAUMONT, 1997a, p. 84, tradução nossa). ${ }^{6}$

5 “[...] a été construit selon un plan d'urbanisme précis, avec une taille prédite au moins dix fois supérieure au noyau existant."

6 “[...] un grand nouveau quartier, avec 100.000 habitants ou plus, construit à côté d'une vieille ville, peut-on définir une nouvelle ville?" 
Indagação que nos remete ao projeto do bairro Cidade Nova de Manaus, idealizado pelo arquiteto e urbanista Ricardo Julião, em 1982, com 1.113 hectares de área e previsão inicial para 75 mil habitantes (REVISTA AU, 1987). Um bairro formado por dezenas de unidades de vizinhança, planejado para absorver o crescimento da capital manauara após a instalação de sua Zona Franca. Uma expansão urbana, sim, mas não uma CN como o nome fantasia nos faz acreditar que seja.

Diferente de Le Havre (França): uma cidade portuária fundada em 1517 que, após ser devastada, em 1944, por bombardeios de tropas aliadas na Segunda Guerra Mundial, foi reconstruída da tabula rasa a partir do projeto do arquiteto belga Auguste Perret (1874-1954), de 1945. Cidade colocada ao lado de outras três CNs - Tel Aviv (1925), de Patrick Geddes; Chandigarh (1952), de Le Corbusier; e Brasília (1957), de Lucio Costa e que, no colóquio "Brasília, Chandigarh, Le Havre, Tel Aviv - villes symboles du XX $X^{e}$ siècle” (set. 2007), foram anunciadas como personificadoras do urbanismo moderno.

Enfim, classificações de CNs, brevemente ilustradas - Santos, Nova York, Barcelona, Boa Vista, Paulínia, Le Havre, Tel Aviv -, que nos induzem a debruçar com maior dedicação sobre o tema. Um olhar à conceituação de CNs que pretendo realizar a partir de definições encontradas em fontes referenciais (livros, artigos, entrevistas etc.), agrupando-as por enfoques aproximativos. Um levantamento que utilizarei, posteriormente, para embasar uma definição funcional, ou seja, uma conceituação pessoal sobre aquilo que entendo por CNs e que permitirá balizar futuros trabalhos sobre esse tipo urbanístico.

\section{Definições empregadas}

Toda as cidades, é claro, já foram “novas”. (OSBORN; WHITTICK, 1977, p. 1, tradução nossa) ${ }^{7}$

7 “All towns, of course, were once 'new'.” 
É consenso: todas as cidades existentes já foram cidades novas em algum momento do passado, geradas a partir de circunstâncias - política, econômica, social e/ou cultural - específicas e implantadas sobre sítios de interesse.

Nesse sentido, o termo cidade nova configura-se como um atributo temporal relacionado ao período do surgimento, da fundação, dos primórdios históricos de uma determinada cidade, como atesta Melville Campbell Branch (1983). Atributo conceitualmente diferente ao trabalhado nesta obra: a cidade nova como um tipo urbanístico.

Para a geógrafa do Institut de Recherche pour le Développement (IRD-Paris), Márcia Regina de Andrade Mathieu, a CN enquanto um tipo do urbanismo pode ser reconhecida a partir do instante de sua criação, apresentando "um ponto de partida preciso, um ato de nascimento localizado no tempo e no espaço", sendo "um estabelecimento previsto com todos os atributos urbanos num espaço inicialmente virgem” (MATHIEU, 2008). Uma delimitação conceitual que ressalta outro ponto importante: o prever uma CN, ideia também trabalhada por Jean-Louis Huot:

Certas [cidades] nascem pelo crescimento sobre um elemento não urbano (castelo), outras pelo desenvolvimento espontâneo a partir de uma vila, outras, enfim, nascem pela vontade do homem num local onde não havia nada ou somente poucas habitações. Quando o plano da cidade é antecipadamente pensado e prevê a localização dos órgãos fundamentais, a aglomeração urbana é desenvolvida num quadro artificial seguindo um plano imposto pela vontade do homem. Esse tipo de aglomeração é frequentemente chamado de cidade criada. (HUOT, 1988, p. 8, tradução nossa). ${ }^{8}$

8 “Certaines naissent par croissance sur un élément non urbain (un château), d'autres par dévellopement spontané à partir d'um village, d'autres enfin par la volonté de l'homme à um endroit où il n'y avait rien, ou seulement quelques modestes habitations. Lorsque le plan de la ville 
Assim, entender CNs, para o autor francês, é ir além da data de sua fundação, é regressar para o período antecessor e verificar as circunstâncias e as ações a elas atreladas. Deslocamento esse que nos permite separar as cidades espontâneas das CNs, as quais foram, no momento anterior ao seu surgimento, concebidas, formuladas, idealizadas, intencionadas, inventadas, pensadas, planejadas, premeditadas, programadas, projetadas...

Designações utilizadas para qualificar uma aglomeração urbana criada ex nihilo (do nada), opondo-se ao desenvolvimento tradicional de uma cidade que, pouco a pouco, adquiriu seu status. Distinção feita, segundo o arquiteto Aldo Rossi, por inúmeros estudos urbanos, ao polarizar cidades planificadas e cidades não planejadas:

As primeiras são concebidas e fundadas como cidades, enquanto que as outras surgiram sem desenho consciente, como estabelecimentos que tiveram um desenvolvimento particular e assim puderam mostrar que elas possuem funções urbanas. O caráter urbano não aparece somente no curso de seu desenvolvimento, e sua estrutura é essencialmente o resultado da agregação de edifícios ao redor de alguns nós pré-urbanos. (ROSSI, 1981, p. 118, tradução nossa). ${ }^{9}$

Definição trabalhada muito antes pelo historiador do urbanismo Pierre Lavedan, em sua obra Géographie des villes:

a été arrêté d'avance em prévoyant l'emplacement des organes fondamentaux, l'agglomération urbaine s'est développée dans un cadre artificiel suivant un plan imposé par la volonté d'un homme. Ce type d'agglomération est souvent appelé ville créée."

9 "Les premières ont été conçues et fondées comme des villes, tandis que les secondes ont surgi sans dessin consciente, comme des établissements qui ont eu un développement particulier et ont ainsi montré qu'ils pouvaient remplir des fonctions urbaines. Le caractère urbain n'est apparru qu'au cours de leur développement, et leur structure est essentiellement le résultat de l'agrégation de bâtiments autour de certains nœuds pré-urbains." 
[...] uma cidade espontânea ou uma cidade querida, o traço de seu plano, os desenhos de suas ruas visivelmente, não se devem ao acaso. Há uma obediência às regras, inconscientemente no primeiro caso, conscientemente e abertamente no segundo. Há sempre um elemento gerador do plano. (LAVEDAN, 1936, p. 55, tradução nossa)..$^{10}$

Nesse sentido, as CNs expõem, sem disfarces, seu processo de formação, revelando a todos os componentes que contribuíram para sua criação e sua materialização. Assumem, com isso, a imagem de cidades pré-concebidas, fato ocorrido na construção da introduced capital de Botswana: Gaborone (1963), que se opõe a outras capitais, como Paris e Londres, ao apreendermos premeditações em sua concepção e implantação (BEST; YOUNG, 1972).

A ideia de CNs induz a uma noção de programação, característica da planificação (BOYER, 1983). Necessita de uma mobilização conjunta de capacidade técnica, material, financeira e institucional do Estado, da coletividade e dos movimentos sociais (BOUMAZA et al., 2006); ou é induzida por um gesto autoritário de um Estado intervencionista ou da tentativa do meio profissional de criar os limites do saber do momento (QUERRIEN; LASSAVE, 2005). Essa ideia surgiu, segundo a arquiteta Maria Elisa Costa, ${ }^{11}$ a partir de:

10 “[...] une ville spontanée ou d'une ville créée, il est certain que le trace de son plan, les dessins de ses rues notamment, n'est pas dû au hasard. Il y a une obéissance aux règles, inconsciemment dans le premier cas, consciemment et ouvertement dans le second. Il y a toujours un élément générateur du plan."

${ }^{11}$ Os arquitetos Maria Elisa Costa e Eduardo Sobral, sob a consultoria de Lucio Costa, projetaram a CN de São Bento da Lagoa em 1975 (não construída). Idealizada para ser implantada no litoral fluminense, próximo a Maricá, a cidade serviria como núcleo balneário para veranistas de fins de semana. Aos moldes de Brasília, seu sistema viário foi trabalhado separando vias de veículos e pedestres, com superquadras sem esquinas ocupadas por torres multifuncionais de 2 pavimentos, barras residenciais semicirculares ou unidades habitacionais isoladas. A área central agregaria todas as funções necessárias para autonomia da cidade, enquanto as margens da lagoa de Maricá e a orla marítima abrigariam a escala bucólica mediante um projeto paisagístico próprio (REVISTA MÓDULO, 1975). 
[...] dois tipos de circunstâncias: a tomada de posse de territórios novos - como as cidades fundadas na colonização do Brasil e Brasília - ou a intenção de organizar uma ocupação regional existente, introduzindo novos núcleos - por exemplo, as new towns inglesas. No primeiro caso, como Lucio Costa diz bem, na Memória Descritiva do Plano Piloto de Brasília, a cidade não é decorrência de um plano regional, mas a causa dele; e, no segundo, a cidade surge a partir de um desenvolvimento regional pré-existente. (COSTA, 2007, entrevista)

Definições pontuais que irão se somar a outras encontradas, selecionadas e aqui apresentadas. Definições direcionadas a qualificar um objeto que se metamorfoseou, assumindo várias facetas ao longo da história.

\section{Cidades novas no tempo}

Kahun, no Egito do século XIX a.C., tida como o primeiro exemplar de cidade planejada em estrutura de grelha no Ocidente. As cidades de dominação grega de Mileto, nas costas da Anatólia (atualmente, Turquia) do século V a.C., ou de Túrios e Pireu, na Grécia do século I a.C. As cidades do Império Romano, como Cosa, implantada estrategicamente ao norte de Roma no século III a.C., e Timgad, no norte africano do século I d.C., como parte do domínio romano sobre aquele continente. As póvoas, ${ }^{12}$ as bastides (vilas militares) e as villes d'évêque (vilas religiosas), na Europa medieval. A asteca Teotihuacán, no México do período pré-colombiano. A Cidade Proibida, na Pequim do século XV. As Leis das Índias que nortearam os projetos das cidades novas da América espanhola. As cidades empresariais europeias, com o advento da indústria a partir do século XVIII. Las Vegas, nos Estados Unidos da América de 1905, e as demais CNs criadas em função do turismo no século XX. As new towns inglesas ou as

${ }^{12}$ Núcleos fundados ou reformados pela prática de arruamento como elemento estruturador do espaço urbano. 
villes nouvelles francesas do pós-Segunda Guerra Mundial. Kiruna, na Suécia, de 1900 e de 2030, uma CN por duas vezes. ${ }^{13}$ Esses são alguns exemplos de que a existência de CNs, há muito, faz parte da história do urbanismo.

Mesmo no Brasil, o caso de CNs antecede os exemplares do período imperial e republicano, como revelam alguns estudos. ${ }^{14}$ Curiosamente, antes mesmo da chegada dos portugueses em solo brasileiro, os nativos indígenas criavam assentamentos com intencional organização espacial. Exemplos disso eram as tribos bororos do Centro-Oeste (SÁ, 1983), cuja distribuição de atividades no espaço derivava de aspectos sociais (clãs), bem como o povo tupi, que cercava sua taba por paliçadas de troncos finos e organizava suas moradas ao redor de um terreiro quadrado, padrão que foi utilizado nas feitorias e vilas no século XVI (AZEVEDO, 1956). A partir daí, as cidades administrativas implantadas na costa - determinadas pelas “Cartas Régias” (MARX, 1980) -, os vilarejos jesuíticos e os assentamentos missionários - extremamente regulares e organizados conforme a ordem religiosa (carmelitas, franciscanos etc.) -, as vilas pombalinas - implantadas na hinterlândia brasileira - e mesmo quilombos construídos por escravos fugitivos representam a trajetória e a diversidade de núcleos regulares em território nacional, desde meros assentamentos incipientes a verdadeiras CNs.

${ }^{13}$ A cidade de Kiruna, Suécia, foi fundada em 1900 por Hjalmar Lundbohm. Uma cidade-modelo, projetada por arquitetos, para abrigar operários que trabalhavam na mina de ferro local. O projeto urbano foi realizado para proteger seus moradores do clima frio (próximo ao círculo polar), com as vias dispostas de modo a resguardar os pedestres dos ventos invernais. Com o passar dos anos, e devido à exploração do minério, o solo urbano começou a ceder e a colocar a cidade em risco de desabamento. Pensando nisso, o Conselho Municipal aprovou a construção da nova prefeitura a cinco quilômetros de seu local original, em zona protegida. A população de 20 mil habitantes será transferida num período de até 25 anos. A empresa mineral Luosavaara-Kiirunavaara (LKAB) vai arcar com a maior parte dos custos de deslocamento da cidade. Ainda espera recriar uma nova cidade-modelo para a Suécia, a nova Kiruna. Trata-se de um caso de uma CN empresarial que se tornará uma CN de realocação (NIHLÉN, 2007).

${ }^{14}$ Como os trabalhos seminais: Vilas e cidades do Brasil colonial: ensaio de geografia urbana retrospectiva, de Aroldo de Azevedo (1956); Subsídios para o estudo da influência da legislação na ordenação e na arquitetura das cidades brasileiras, de Francisco de Paula Dias de Andrade (1966); Evolução urbana no Brasil (1500/1720), de Nestor Goulart Reis Filho (1968); e Novas vilas para o Brasil-Colônia: Planejamento espacial e social no século XVIII, de Roberta Marx Delson (1979). 
Esse breve panorama histórico, mundial e brasileiro sobre CNs revela a origem remota de tal tipo e sua difusão abrangente. Um cenário comprovado na obra Bibliographie sur les villes nouvelles françaises, de Pierre Merlin e Mireille Gely (1989), cuja ampla pesquisa sobre estudos de CNs - não apenas francesas - exibe, dentre os inúmeros temas abordados, bibliografias sobre suas origens (anteriores à Revolução Industrial e às utopias urbanas do século XIX) e sobre as ocorrências no exterior (na Europa Ocidental e Oriental, nos EUA, no Oriente Médio, na Ásia, na Oceania, na África, na América Latina e no Brasil).

É uma fonte referencial e, simultaneamente, um atlas de CNs no mundo, similar aos trabalhos realizados por Pierre Merlin em Les villes nouvelles (1969a); por Claude Chaline em Les villes nouvelles dans le monde (1985); e por Frederic Osborn e Arnold Whittick em New towns: their origins, achievements and progress (1977), que, ao finalizarem seu livro, anexaram um quadro com centenas de CNs criadas a partir de 1900: uma tabela organizada por países e respectivos exemplares - por exemplo, no Brasil, citam-se apenas: Brasília, Cidades dos Motores e Volta Redonda -, contendo: informações gerais, datas de designação, população prevista e atual, além de menções sobre a existência de outros casos não relatados, como a ex-União Soviética, onde os autores creditam a presença de 1.000 a 2.000 CNs.

São obras que se contrapõem a relatos e estudos restritivos, que situam a execução desse tipo urbanístico a uma única região, como fez Vincent Fouchier (secretário geral do Programme interministériel d'histoire et d'évaluation des villes nouvelles), ao considerar as CNs como "um fenômeno, sobretudo, do norte-europeu” (apud DIEBOLD; LEMONIER, 2001, p. 10, tradução nossa). ${ }^{15}$ Ou ainda dezenas de pesquisas que enquadram CNs como um produto da teoria de Ebenezer Howard e suas cidades-jardins (1898). Curiosamente, em busca nos arquivos estrangeiros pela temática CNs, os resultados obtidos quase sempre conectavam o termo a programas de cidades-satélites criadas ao redor de uma grande metrópole

15 “[...] un phénomène principalement de l'Europe du Nord.” 
após a Segunda Guerra Mundial, fosse na Europa, na Ásia, nas Américas, na África ou na Oceania, tendo a teoria Cidade-jardim como influência direta.

O termo cidades novas (tradução de new towns), associado à teoria howardiana de cidade-jardim, imputa um caráter específico ao nosso objeto de interesse: o de controlar a expansão das grandes cidades pela criação de novos núcleos.

A origem do ideário cidade-jardim remete à publicação do livro To-morrow: a peaceful path to real reform (Para o-amanhã: um caminho tranquilo para a reforma autêntica) no ano de 1898, de autoria de Ebenezer Howard. Reeditado em 1902, com o título Garden cities of tomorrow (Cidades-jardins de amanhã), esse documento tornou-se paradigmático para o urbanismo moderno ao apresentar um novo tipo urbano - uma cidade diferenciada em seus aspectos físicos e em sua organização econômica, política e social. Ainda apresenta uma discussão sobre o futuro das cidades. A expansão da cidade idealizada pelo taquígrafo inglês dar-se-ia pela construção de outras representadas em diagramas. Os esquemas mostram uma rede de sete cidades interligadas pela ferrovia, sendo seis cidades menores periféricas - com 32 mil habitantes - e uma central chamada de Cidade Social - com 58 mil habitantes. Essa cidade centralizaria um número de atividades maior do que as demais (CREESE, 1992) - um protótipo de várias versões.

As CNs, nesse caso, surgem como um tipo de planejamento urbano e territorial de desindustrialização e de desurbanização das grandes cidades congestionadas, como aponta Guy Baudelle (2004). Uma vez implantadas, absorveriam uma parte significativa do crescimento demográfico urbano e criariam zonas de atividades econômicas ao redor de uma cidade vultosa. Nesse sentido, as CNs no século XX adquirem uma função que irá, às vezes, restringir sua definição a um mecanismo de expansão urbana organizada.

São inúmeros os autores que associam CNs às cidades criadas para controlar o crescimento de outras existentes. A iniciar por René Allart (s.d., p. 12, tradução nossa) ${ }^{16}$ e sua comparação entre os tipos inglês e francês:

16 “Il faut équiper des terrains neufs, les transformer en "tissu urbain”. La démarche qui a consisté à présenter en face de l'urbanisation périphérique, moyen classique d'extension des villes, la 
É preciso equipar os terrenos novos, transformá-los em tecido urbano. A demanda necessária apresentou, em face à urbanização periférica - meio clássico de extensão das cidades -, a possibilidade de se criar cidades novas, nascidas de uma dupla reflexão: uma constatação do colapso de formas clássicas de urbanização francesa [o crescimento radioconcêntrico] e uma reflexão crítica sobre aquilo que chamamos de sucesso das cidades novas inglesas.

E a análise de Sabine Fachard (1982, p. 38, tradução nossa) ${ }^{17}$ sobre as villes nouvelles da grande Paris:

As grandes linhas do "projeto villes nouvelles" são conhecidas: trata-se de distanciar as contradições da cidade, pesquisa do equilíbrio moradia-emprego, comodidades da cidade sem os problemas da cidade tradicional, com bons serviços interior e exterior, equipamentos e comércios, ruas, praças, vastos corredores verdes, parques urbanos, bases de lazer, etc.

Incluindo ainda a classificação dos dois tipos, feita por Françoise Choay e Pierre Merlin (2005), conforme a conexão entre CNs e a cidade principal: o tipo inglês (new towns), com CNs situadas nos arredores de uma metrópole, sem continuidade, com a preocupação de descongestionar e de estruturar a região urbana em uma escala mais vasta que aquela da aglomeração de base; e o tipo francês (villes nouvelles), com CNs situadas em continuidade espacial com grandes aglomerações,

possibilite de créer des villes nouvelles, est née d'une double réflexion: um constat d'échec des formes classique de l'urbanisation em France e une réflexion critique sur ce que l'on appelle le succès des villes nouvelles anglaise."

17 "Les grandes lignes du "projet ville nouvelle" sont connues : il s'agit du fait de dépasser les contradictions de la ville, recherche d'équilibre habitat-emploi, commodités de la ville dégagée des contraintes de la ville traditionnelle, à savoir bonnes dessertes intérieures et extérieures, équipements et commerces, rues, places, mais aussi vastes coulées végétales, parcs urbains, bases de loisirs, etc.” 
destinadas a orientar e estruturar o desenvolvimento das periferias, sem sinal de independência entre elas e a cidade-mãe.

Enfim, CNs que surgem como solução ao espraiamento urbano desordenado, difundidas, principalmente, no período de reconstrução europeia no pós-Segunda Guerra Mundial, como na Grã-Bretanha e seu New Town Act de 1946, cuja autoria é dada ao urbanista Patrick Abercrombie (1879-1957).

Tratava-se de um plano - embasado, por exemplo, na obra The building of satellite towns (A construção de cidades-satélites), de Charles Benjamim Purdon (1925) -, que previa a necessidade de descentralização das grandes cidades britânicas e propunha uma reforma da legislação urbanística existente. Uma proposta de renovação urbana que acarretou na geração de dezenas de new towns por todo o território inglês, independentes econômica e administrativamente dos centros urbanos existentes (CLAPSON, 1998).

Em oposição às new towns inglesas - distantes e carentes de ligação com Londres (BEHAR; ESTEBE; GONARD, 2002) -, as villes nouvelles francesas, para Vito Ahtik (1969, p. 385, tradução nossa), ${ }^{18}$

[...] se apresentam num contexto de reestruturação da área metropolitana. O conjunto do projeto de planejamento se articula entre a reconstrução do centro tradicional da metrópole e a criação de alguns nós na armadura urbana. Cada cidade nova terá uma vocação privilegiada (setor terciário ou quaternário). Enfim, a cidade nova

18 “[...] s'inscrit d'emblée dans le contexte de la restructuration de l'aire métropolitaine. L'ensemble du projet d'aménagement s'articule donc entre la reconstruction du centre traditionnel de la métropole et la création de quelques nœuds de l'armature urbaine. Les différents activités doivent s'ordonner au sein de cet ensemble. Chacune des villes nouvelles aurai donc une vocation privilégiée (dans la plupart des cas, un fort accent est mis sur le secteur tertiaire ou quaternaire). Enfin, la ville nouvelle s'isole de la métropole (soit géographiquement, soit par une ceinture verte, un lac ou du fait de la clôture du site), mais en même temps elle se situe sur un des principaux axes de communication de la région. En termes de nos catégories d'analyse, la ville nouvelle française ne se veut ni satellite, ni autonome, mais une ville secondaire; ni complètement différenciée, ni spécialisée, mais à vocation privilégiée ; ni concentrée, ni diffuse, mais un pôle intégré à l'ensemble de l'aire métropolitaine." 
francesa se isola da metrópole (seja geograficamente, seja por um cinturão verde, um lago, ou por condições de topografia), mas, ao mesmo tempo, ela se situa sobre um dos principais eixos de comunicação da região. Em termos de categoria de análise, a cidade nova francesa não é nem satélite, nem autônoma, mas uma cidade secundária; nem completamente diferenciada, nem especializada, mas de vocação privilegiada; nem concentrada, nem difusa, mas um polo integrado ao conjunto da área metropolitana.

As villes nouvelles foram CNs empreitadas durante a presidência do general Charles de Gaulle (1890-1970), entre 1958 e 1969, sob o comando do delegado geral Paul Delouvrier (1914-1995). São núcleos que não deveriam se assemelhar às CNs inglesas, mas incorporar o sentido de "centros urbanos novos", de "cidades antiperiferia”, como desejado por Delouvrier e sua equipe. De centros urbanos novos a villes nouvelles, o uso do termo CNs em francês se consolidou apenas anos mais tarde, conforme o próprio Delouvrier, em 1966, explicou (MURARD; FOURQUET, 2004). A escolha do termo ville nouvelle, em detrimento de centre urbain nouveau, foi uma questão semântica. Ao pronunciar os novos projetos ao Ministério de Finanças ou mesmo à população, mediante a segunda expressão, nenhum resultado surtiria, ao passo que o primeiro termo teria uma chance de ser aceito (assimilado como algo novo, que receberia novos equipamentos para estas regiões periféricas à capital francesa); algo distante de uma renovação e sim próximo ao senso de colocar a aglomeração parisiense no século XX. Estando situadas na região parisiense, sendo na verdade uma forma moderna de periferia - diferente aos criticados conjuntos habitacionais periféricos: as HBMs (Habitation à Bon Marché) -, essas villes nouvelles poderiam receber equipamentos que o centro de Paris não mais comporta por falta de espaço: museus ultramodernos, teatros e desenvolvimentos artísticos novos. O delegado geral ainda apontou que: 
Em vez de abrir uma sequência de loteamentos, nós pensamos em levar serviços, universidades, grandes estabelecimentos, órgãos públicos regionais, áreas de esporte para o centro das periferias novas que não serão mais periferia, mas lugares denominados de villes nouvelles. Mas estas villes nouvelles sejam a forma moderna de crescimento de Paris e não mais cidades antiperiferia que pudessem ser colocadas em qualquer parte do território. Aí está, para mim, a escolha decisiva. (DELOUVRIER apud MURARD; FOURQUET, 2004, p. 128, tradução nossa). ${ }^{19}$

Portanto, ao requalificar o modo de fazer e nomear a periferia da grande cidade, as villes nouvelles francesas geram um novo significado do termo CNs e surgem como reinterpretação do tipo inglês.

Sejam inglesas ou francesas, independentes ou dependentes, isoladas ou continuações de cidades-mães, esse tipo de CNs foi adotado em inúmeros países no entorno de capitais, como Helsinque, Estocolmo, Copenhague, Amsterdã, Seul, Argel, Cairo, Caracas e Brasília.

Tipo que, por vezes, ganha novos nomes, como as twin towns e as new towns in-town. As cidades gêmeas, discípulas dos exemplares britânicos e israelenses de CNs, aparecem como um plano estratégico para a construção de novas cidades na Palestina, visando a suprir necessidades de moradia e oferecer empregos. Localizadas próximas a uma cidade existente, reforçando seu processo de urbanização, as twin towns foram programadas em duas etapas: primeiramente, implantação na periferia de metrópoles e, posteriormente, ao redor de cidades menores, promovendo seu crescimento (KHAMAISI, 1998).

19 “Au lieu de faire une file de lotissements, nous avons pensé qu’il fallait amener les services, universités, grands établissements, préfectures, terrains des sport au cœur des banlieues nouvelles qui ne seront plus des banlieues et qui ainsi prennent le nom de villes nouvelles. Mais ces villes nouvelles sont la forme moderne de la croissance de Paris et non pas des villes complètement autonomes que l'on aurait pu placer n'importe où. Voilà ce que nous avons voulu faire." 
Já as CNs-na-cidade aparecem pela primeira vez em 1966, como título do artigo escrito pelo norte-americano Harvey S. Perloff, publicado no Journal of the American Institute of Planners. Perloff sugeriu, no início dos anos 1950, uma estratégia para desenvolver uma área ao redor da Universidade de Chicago e, em 1966, ele fez a mesma proposta como base para um programa nacional. Ele via o conceito de new towns in-town como uma revitalização de grandes áreas urbanas pelo aproveitamento do ambiente já existente e pela qualidade de vida de seus moradores, incorporando um simples programa (uma variedade de atividades para assistência aos habitantes e componentes de desenvolvimento urbano). Tal conceito foi traduzido por Pierre Merlin e Michel Sudarskis (1991) como operações de renovação e de regeneração urbanas; ou como novas zonas industriais em áreas urbanas, tornando-se polos de desenvolvimento empreendidos por políticas públicas (D’ARC; SCHNEIER, 1983).

Também foi um conceito que embasou o American Model Cities Programme (Programa Americano de Cidades-Modelo), proposto em fins dos anos 1960, nos Estados Unidos da América. O programa, instituído no governo do presidente Lyndon Baines Johnson (1908-1973), pretendia construir pequenas, novas e dinâmicas comunidades em terras federais inseridas em algumas cidades norte-americanas. Buscava-se levar melhorias físicas e sociais a complexos urbanos carentes por meio de planejamento, readequação do traçado, transporte, equipamentos de saúde, educação e segurança. Essas cidades-modelo foram iniciadas, mas nenhuma foi efetivamente concluída (PHILLIPS; YEH, 1987).

De Kahun às new towns in-town, das vilas e mochas do período colonial brasileiro às CNs derivadas da teoria howardiana, passando pelas peculiaridades que distinguem new towns e villes nouvelles, temos um apanhado histórico que nos permite ter uma maior compreensão sobre o universo das CNs, bem como verificar seus desdobramentos funcionais e suas aplicações em contextos diversos - verdadeiro campo de experimentações, como alguns autores preferem defini-las. 
Cidades novas como laboratórios socioespaciais

Criar uma cidade [...] é sempre criar uma cultura, quer dizer os modelos individuais e comuns de atitudes. Augustyn Bańka, Structure psychologique de la planification du milieu, 1985 (apud HAUMONT, 1997a, v. 2, p. 153, tradução nossa). ${ }^{20}$

Além de definições aplicadas segundo o momento histórico, as CNs foram também definidas como experimentações sociais e físicas na busca por uma melhor qualidade de vida e como delineamento traçado por estudiosos e pesquisadores preocupados em caracterizar as CNs como laboratórios, com os mais variados tipos de ensaios.

A maior parte das propostas de cidades idealizadas surgiu como uma crítica à cidade contemporânea e pelo desejo de se criar a condição de reequilíbrio social, educando seus habitantes mediante sua organização e sua arquitetura, dando-lhes a condição necessária para o seu desenvolvimento socioeconômico. Trata-se de um tipo de cidade unitariamente projetada, a absoluta presteza do idealizador e do construtor de poder prever as necessidades físicas, psíquicas dos habitantes e de traduzi-las em formas arquitetônicas (BERTUGLIA; TICH; STANGHELLINI, 2004). Concretizações de uma ideia, dentre as quais muitas foram destinadas a serem cidades-modelo, tendo em comum uma ideia de partida, que não são somente alojamento e infraestrutura, mas sim uma manifestação física de certa ideia de vida urbana; manifestos políticos daquilo entendido como vida urbana para seus habitantes (SAFIER, 1977).

Do ideal ao real, as CNs foram constantemente alimentadas pela busca de condições melhores, mediante “ações inovadoras e experimentais” (MONTAGU; SOKOLSKY, 1995, s/p, tradução nossa), ${ }^{21}$ como aquelas implementadas na primeira cidade-jardim: Letchworth (1903), na Inglaterra, e na colônia agrícola de

\footnotetext{
20 “Créer une ville [...] c'est toujours créer une culture, c'est-à-dire des modèles d'attitude individuels et communs." "

21 “[...] actions innovantes et expérimentales [...]"
} 
Ceres (1941), no estado de Goiás, Brasil. Duas cidades mais distantes do que geograficamente, porém unidas por princípios sociais estipulados por seus criadores.

Em Letchworth, projetada pelos arquitetos Raymond Unwin (1863-1940) e Richard Barry Parker (1867-1947), sob o olhar atento de Ebenezer Howard, todo o plano da $\mathrm{CN}$, assim como seu tranquilo funcionamento, foi pautado em regulamentos estabelecidos pela First Garden City Ltd. e, posteriormente, pelos primeiros moradores. Criaram-se normas e regras para o uso do solo e controle do conjunto paisagístico, proibiu-se a abertura de casas comerciais na área residencial, a implantação de indústrias poluidoras, a abertura de lojas de bebidas alcoólicas ${ }^{22}$ e até o toque de sirenes nas fábricas ou sinos em igrejas e escolas. Também enunciaram o tipo de construções, o número limitado de artesãos por bairro para garantir clientela e o controle sobre a criação de animais domésticos para que não perturbassem os vizinhos (HALL, 1995; HOWARD, 1996).

Já Ceres, considerada uma colônia agrícola modelo e uma das maiores produtoras de cereais do estado de Goiás nos anos 1940 e 1950, foi projetada pelo agrônomo carioca Bernardo Sayão Carvalho Araújo (1901-1959), responsável também pelas rígidas normas de posturas e condutas sociais da CN. Bernardo Sayão "não admitia bebidas, prostituição e jogo na área da colônia” (MARQUES, 2009, p. 1), acarretando, na criação de outro assentamento vizinho, Rialma, na margem oposta do Rio das Almas, a permissividade de quase tudo o que era proibido na colônia!

Letchworth e Ceres são, portanto, classificadas como CNs não somente pelas circunstâncias envolvidas, mas também pelos aspectos sociais determinados por seus criadores a partir da cultura em voga.

Nesse sentido, as CNs como campo de experimentação social foram analisadas por Sabine Fachard (1982), que as diferenciou da cidade tradicional durante seu

\footnotetext{
${ }^{22}$ Em sua obra teórica sobre as cidades-jardins, Ebenezer Howard dedicou um capítulo exclusivo ao tema da venda de bebidas (capítulo VII), um problema que as cidades inglesas apresentavam. O alto índice de alcoolismo, principalmente na massa operária - um possível escape da realidade caótica urbana e das condições imorais de trabalho -, levou o autor a proibir a venda de bebidas em sua cidade idealizada.
} 
estágio inicial, em que o modo de vida é mais intenso e mais diversificado. Para a autora, após estudos das villes nouvelles francesas dos anos 1960,

[...] as cidades novas vieram substituir um sistema complexo de organização espacial e funcional voluntário, onde cada questão colocada exige uma resposta e meios compatíveis com a coerência do conjunto. [...] A margem de liberdade que oferecem as cidades novas é uma especificidade que muito lhes convém, mas que tem por corolário a necessidade de fazer escolhas: decidir aquilo que é bom ou ruim. (FACHARD, 1982, p. 38, tradução nossa). ${ }^{23}$

Esse é um processo de vida que permite aos futuros habitantes da CN uma mudança, como colocou Anatole Kopp em seu livro Changer la vie, changer la ville (1975). Para mudar a vida, haveria a necessidade de mudar a cidade, ou melhor, de cidade. Era a oportunidade para os mais jovens conseguirem empregos promissores, adquirir sua moradia, garantir qualidade de vida para seus filhos etc. Um novo modo de vida, ideal para casais jovens com crianças (DUCON; YOKOHARI, 2006), como verificado na cidade-satélite de Águas Claras, Brasília.

A mais nova das cidades-satélites do Distrito Federal brasileiro, concebida nos anos 1980 pelo arquiteto Paulo Zimbres (1933-2019), atrai um perfil de habitantes único e diferenciado das demais. Segundo último censo registrado (2010), jovens casais com filhos entre 0 e 6 anos, de classe média, trabalhadores no Plano Piloto, escolheram a cidade-satélite de Águas Claras como sua morada na capital federal. A cidade prevista como resposta ao urbanismo modernista segregador existente no Plano Piloto de Lucio Costa (1902-1998) e nas cidades-satélites mais antigas infe-

23 “[...] les villes nouvelles sont venues substituer un système complexe d'organisation spatiale et fonctionnelle volontaire où chaque question posée exige une réponse et des moyens compatibles avec la cohérence de l'ensemble. [...] La marge de liberté qu'offrent les villes nouvelles est une spécificité que beaucoup leur envient mais qui a pour corollaire la necessite de faire des choix: en clair, décider de ce qui est 'bien' et de ce qui est 'mal'."' 
lizmente se transformou, com o aval estatal e o domínio das construtoras privadas, em uma cidade com características típicas das áreas de expansão urbana no Brasil: torres habitacionais com mais de 20 pavimentos; espaços públicos desqualificados - praças abandonadas, muros contínuos, calçadas intransitáveis, centralidade não definida etc. -; áreas de lazer privatizadas em espaços condominiais; ruas estreitas para um fluxo intenso de veículos etc. Talvez por esse cenário familiar - aliado a uma resistência em habitar as superquadras de Lucio Costa - ou pela oferta imobiliária, muitas famílias vindas dos diferentes recantos do país tenham optado por Águas Claras como a cidade para o começo de uma nova vida.

Seja por condições pré-estabelecidas, seja por condições convidativas a um público específico, as CNs propiciam um novo gênero de vida, em que a posição das grandes funções urbanas - moradia, emprego, transporte etc. - leva em conta os novos modos de posicionamento individual e coletivo (VERMEERSCH, 2005). No Japão, por exemplo, a CN de Tsukuda surgiu como solução a um dos males da vida contemporânea. Fundada em 2000, a nordeste de Tóquio, esse assentamento nasceu com um novo conceito para os padrões de vida urbana: a slow life (vida pacata), contrapondo-se ao estresse e à agitação das grandes metrópoles. Um estilo de viver específico, que leva autores como Bertrand Warnier (1988) a taxar as CNs como apenas um problema de planejamento do quadro de vida ou um parto de planificação urbana, e não um pacto urbanístico.

Mas se, para alguns pesquisadores, as CNs se tornaram lócus para composições sociais particulares - espaço para controle ou libertação de seus futuros habitantes -, para outros estudiosos elas também se caracterizaram como verdadeiros laboratórios urbanístico e arquitetônico.

Ao suscitar indagações como: a cidade nova apresenta uma concepção e um método particular de urbanismo? Havia uma arquitetura específica? Como ocorreu sua inserção no meio escolhido para sua implantação? As cidades novas eram um laboratório sobre o plano de qualidade arquitetônica, urbanística e ambiental? Pierre Merlin e Michel Sudarskis (1991) nos atentam para a temática como um 
vasto arcabouço de experiências projetuais; como uma temática de linguagem própria (VADELORGE, 2005); ou, ainda, como “um momento de criação privilegiado [...], um tipo de laboratório ideal” (POITEVIN; ETTEINGER; ANTIER, 1993, p. 189, tradução nossa). ${ }^{24}$ Isso pode ser verificado na proposição de pequenas cidades-estado a serem criadas nos oceanos, uma ideia patrocinada pelo bilionário norte-americano Peter Thiel e comandada pelo Seasteading Institute. Tratam-se de plataformas flutuantes ancoradas em águas internacionais, sem relação com qualquer país e, portanto, independentes politicamente: verdadeiras CNs flutuantes. Ou seja, experiência urbanística e arquitetônica que aproxima as CNs dos conceitos de inovação ou cidade-objeto. Para Gilbert Smadja (1987, p. I, tradução nossa), ${ }^{25}$ a “inovação é consubstancial às cidades novas. Já no início, o projeto e sua implantação estão situados num contexto de abertura à inovação”. Cada CN é uma cidade-objeto, sendo uma projeção no futuro a partir de lições da história e dos contratempos do tempo presente (BOUMAZA et al., 2006).

Inovadoras e objetos idealizados, tais CNs propiciam um estudo minucioso, servindo de referência histórica, como salienta Aymeric Zublena:

Se um historiador de arquitetura urbana desejasse estudar a evolução das concepções arquitetônicas entre os anos 1960 e 1980, é nos centros urbanos das cidades novas que ele encontraria o mais rico terreno de análise. (apud FRANCE, 2007, p. 80, tradução nossa). ${ }^{26}$

24 “[...] un moment de création privilégié [...], un type de laboratoire idéal. »

25 “[...] innovation est consubstantielle à villes nouvelles. A l'origine, le projet et sa mise en ouvre s'inscrivent dans un contexte d'ouverture à l'innovation [...].”

26 "Si un historien de l'architecture urbaine voulait étudier l'évolution des conceptions architecturales au cours des annés 1960 à 1980, c'est dans les centres urbaines des villes nouvelles qu'il trouverait le plus riche terrain d'analyse." 
Essa é uma afirmativa similar às colocações de Alain Coulon, ao situar as CNs como a materialização temporal de uma arquitetura e de um urbanismo recorrentes numa época:

[...] as cidades novas estão inscritas numa produção espaço-temporal como testemunhas físicas da evolução das práticas num período de transformações radicais, e que as contradições formais inerentes ao sistema de produção (divisão de espaços e justaposição das tecno-práticas) constituem a infraestrutura visível de uma imagem física da cidade moderna. (COULON, 1993, p. 90, tradução nossa). ${ }^{27}$

e de Vincent Fouchier, ao qualificar as villes nouvelles francesas:

As cidades novas foram um terreno privilegiado para as tentativas de experimentações arquitetônicas, onde podemos observar in loco a evolução em curso dos seus 40 anos. (apud DIEBOLD; LEMONIER, 2001, p. 13, tradução nossa). ${ }^{28}$

Já Françoise Choay e Pierre Merlin, embora compartilhem da ideia de CNs como laboratórios, fazem uma distinção entre o urbanismo e a arquitetura presentes nas cidades do tipo satélite (CNs de expansão urbana):

\footnotetext{
27 “[...] ces villes nouvelles ont inscrit, dans leur production spatio-temporelle le témoignage physique de l'évolution des pratiques dans um période de leur transformation radicale, et que les contradictions formelles inhérentes au système de production (division des espaces et juxtaposition des techno-pratiques) constituent l'infrastructure visible d'une image physique de la ville moderne."

28 "Les nouvelles villes étaient un terrain privilégié pour les tentatives d'expérimentation architecturale, où l'on peut observer l'évolution continue de ses 40 ans."
} 
Se as CNs foram, frequentemente, em seus países (ex-URSS, Grã-Bretanha, França, Holanda, Suécia, Finlândia), laboratórios em matéria de urbanismo, oferecendo um meio de vida melhor que as periferias ordinárias, elas não se constituíram, no entanto, sobre o plano da arquitetura (à exceção de algumas realizações isoladas como Tapiola, na Finlândia), um conjunto de inovação esperada. (CHOAY; MERLIN, 2005, p. 946, tradução nossa). ${ }^{29}$

Seja qual for a leitura empregada, tais "laboratórios in vivo" do urbanismo e da arquitetura podem ser, atualmente, visitados, estudados, analisados e criticados, a exemplo de Chandigarh (1952) e Brasília (1957), verdadeiros museus modernistas ao ar livre (PELLETIER; DELFANTE, 2000, p. 113).

Mesmo as villes nouvelles francesas, com suas soluções espaciais miraculosas, transformaram-se em espaço para o turismo arquitetônico (WERMES, 1991). Após a iniciativa de criação das cinco CNs no entorno parisiense - Évry, Cergy-Pontoise, Marne-la-Vallée, Melun-Sénart e Saint-Quentin-en-Yvelines -, o Estado promoveu uma sequência de concursos, cada um com diferentes níveis de intervenções, divididos em três grandes grupos: 1) grandes concursos de urbanismo (arquitetura e organização urbana de áreas de 700 a 7 mil moradias); 2) concursos de habitação (áreas de 70 a algumas centenas de moradias); e 3) concursos de espaços públicos. A quantidade de concursos possibilitou uma diversidade de projetos realizados por mais de 260 arquitetos e urbanistas, dos quais se destacam: Ricardo Bofill, Christian de Portzamparc, Jean Nouvel, Alain Sarfati, Tomasz Fiszer, Manuel Nuñez Yanowsky etc. Nesse rico acervo urbanístico e arquitetônico pós-moderno, encontram-se: o Espaço de Abraxas, um complexo residencial composto por três prédios: Teatro, Palácio e Arco, desenhado pelo arquiteto espanhol Bofill em 1982;

${ }^{29}$ Si les villes nouvelles ont souvent été, dans leur pays - ex-URSS, Grande Bretagne, Pays-Bas, Suède, Finlande, France - , des laboratoires en matière d'urbanisme, offrant un milieu de vie plus satisfaisant que les banlieues ordinaires, elles n'ont pas toujours constitué, sur le plan architectural (à l'exception de quelques réalisations isolées comme Tapiola en Finlande), le foyer d'innovation attendu. 
e as Arenas de Picasso, um conjunto de habitação para baixa renda, construído entre 1980 e 1984, elaborado pelo arquiteto Uzbeque Yanowsky.

Inovações e experimentações que chegam ao exagero, como nos projetos para a cidade-satélite dinamarquesa de Albertslund (1963), nos arredores de Copenhague, com a predominância de uma arquitetura mediterrânea; e para a CN chinesa de Gaoqiao, no entorno de Xangai, com sua arquitetura holandesa (MING, 2003). Em ambos, a tentativa de reproduzir, ipsis litteris, ambientes localizados a milhares de quilômetros do sítio de origem - longe, portanto, de seu devido contexto socioambiental - foi o modo encontrado por incorporadores de comercializar arquiteturas historicamente aceitáveis. Assim, o fake arquitetônico e urbanístico se torna moeda imobiliária e o modo de vida, uma indagação: teriam os nativos adquirido as características culturais de gregos ou holandeses?!

Ironias à parte, a programação de CNs é um ato de construção, no abstrato e na realidade, de uma totalidade utópica, coerente com as perspectivas do Estado promotor e assinado por arquitetos-urbanistas ou por outros profissionais. Laboratórios que absorveram fórmulas de experiências, inusitadas ou não, na tentativa de criar uma sociedade ideal inserida num espaço planejado. Experimentações espaciais que fazem das CNs um tipo particular na urbanística. Espaços que buscam, ao menos no início, determinar, modular, regrar os comportamentos sociais de seus habitantes.

\section{Definições-síntese e definições fracionadas}

Por fim, nesse trajeto em busca dos diferentes conceitos aplicados, há definições empregadas com o intuito de qualificar as estruturas que compõem as CNs. Um número extenso de conceituações, como atestou o crítico francês Jean-Louis Cohen (2008), que organizo em duas esferas neste livro: as definições-síntese e as definições fracionadas. As primeiras referem-se à reunião coerente dos elementos compositivos das CNs, enquanto as segundas abrangem leituras pontuais sobre alguns desses elementos, como: terminologias, vontade pública ou privada, funções 
pré-estabelecidas, território, envolvimento profissional, traçado, tamanho populacional, tempo de desenvolvimento, além de atribuições genéricas.

O interesse por uma definição precisa começou a partir de meu primeiro encontro com o professor-urbanista Philippe Panerai, em seu bureau da rue des Feuillantines, em Paris. Ao ser indagado sobre o que seria uma CN, ele prontamente me respondeu:

Uma cidade nova é uma cidade cuja implantação e construção foram geradas por uma decisão, num sítio onde não existia uma cidade, mas ali poderia estar uma vila, um forte, uma usina [...]. (PANERAI, 2007, entrevista, tradução nossa). Uma simples pergunta que, ao ser respondida, instigou-me a vasculhar livros e revistas à procura de respostas equivalentes. ${ }^{30}$

Se, para monsieur Panerai, a vontade, a localização estratégica e a função caracterizam uma $\mathrm{CN}$, outros autores compartilham da mesma ideia, a começar por Françoise Choay e Pierre Merlin (2005) que, em seu Dictionnaire de l'urbanisme et de l'aménagement, definem ville nouvelle como uma "cidade planificada onde a criação foi decidida pela via administrativa”, classificando-a, segundo as funções para qual foi criada, em:

As cidades novas implantadas fora de regiões urbanizadas, para fins industriais (ex-União Soviética), para equilíbrio da rede urbana (Hungria), sobre recursos minerais (company towns do Canadá) [...]. As novas capitais implantadas distantes de grandes aglomerações por razões de políticas de interiorização, de estratégias defensivas, para favorecer o desenvolvimento de regiões pioneiras ou por todas estas razões: Washington, Canberra, Brasília, Islamabad, Abuja etc,

\footnotetext{
30 "Une ville neuve est une ville dont l'implantation et la construction sont créées par décision dans un site où il n'y a pas de ville, mais il peut y avoir un village, un fort, une usine [...]."
} 
são os exemplos mais conhecidos. (CHOAY; MERLIN, 2005, p. 944, tradução nossa). ${ }^{31}$

“Cidade planificada”, que Adauto Lúcio Cardoso exemplifica ao mencionar Brasília em seu texto O urbanismo de Lucio Costa: contribuição brasileira ao concerto das nações, posicionando-a como fruto de um pensamento racional em busca de um ideal:

[...] um ato fundador da racionalidade, que incorpora um território estranho aos domínios do desenvolvimento, imagem de uma nova nacionalidade, e que se transforma em síntese de uma modernização que pode ser purificada de seus problemas, se orientada a partir da intervenção organizadora de um poder racionalizador e normatizador. (CARDOSO, 1996, p. 111).

Planificação, desejo e localização, aspectos aos quais Farhad Atash (2000) adiciona a diversidade dimensional das CNs, variando de "pequenas comunidades coexistindo com áreas urbanas pré-existentes até assentamento de grande escala”; e inclui novas funções específicas, como: “descongestionamento urbano; reavivar economicamente áreas decadentes; oferecer moradias” (ATASH, 2000, p. 68, tradução nossa). ${ }^{32}$

Não bastasse, Pierre Laconte et al. (1982) se unem a esses autores ao delimitarem as CNs a um conjunto urbano planificado, implantado numa área até então agrícola, e refletindo o sistema de valores ideológicos e políticos do promotor, que está tanto no

31 "Les villes nouvelles implantées hors des régions urbanisées, à des fins industrielles (ex-Union soviétique), d'equilibre du réseau urbain (Hongrie), sur des ressources minières (Company Towns du Canada) [...] Les nouvelles capitales implantées à l'écart des grandes agglomérations pour des raisons de politique intérieure, de stratégie défensive, pour favoriser le développement de régions pionnières ou pour plusieurs de ces raisons: Washington (fin du XVIII ${ }^{\text {) }}$, Canberra (années 1920), puis Brasilia, Islamabad, Abuja (Nigeria), etc., en sont les exemples les plus connus.”

32 “[...] petites communautés coexistant avec des zones urbaines préexistantes et des agglomérations à grande échelle [...] décongestion urbaine; faire revivre économiquement des zones décadentes; offrir des habitations [...].” 
setor público (maioria dos casos) como no setor privado, este podendo ser comercial (Columbia, em Maryland, EUA) ou sui generis (Letchworth, Welwyn Garden City, Tapiola, Louvain-la-Neuve, na Bélgica). À leitura do local e da ação promotora é somada uma análise do tempo de desenvolvimento e das estruturas urbanas necessárias:

O caráter planejado da cidade nova, ou de um conjunto urbano, atrai normalmente um fluxo importante de população em um lapso de tempo restrito. Outra característica própria das cidades novas é a necessidade de produzir, em um curto período, um estoque importante de vias, redes diversas e equipamentos sociais. (LACONTE et al., 1982, p. 107). ${ }^{33}$

Nessa breve apreensão, revelo - e atesto por diagnóstico feito a partir de referências analisadas durante a pesquisa - um consenso conceitual marcado pela diversidade de componentes comuns às CNs. Contudo, ao debruçar com mais atenção sobre alguns trabalhos, deparei-me com outros elementos peculiares, como a diferenciação entre CNs e meros loteamentos periféricos.

Tanto Gilles Leloup (1983) quanto Jack Underhill (1983), ao explanarem sobre CNs, além de ressaltar qualidades já citadas, destacam o equilíbrio. Para ambos os autores, as CNs devem ser equilibradas na relação moradia e emprego, algo primordial para distingui-las de meras cidades-dormitórios ou de simples expansões periféricas de uma grande cidade. Pierre Bloc-Duraffour (1998) enfatiza a importância de tal estabilidade na formação de uma identidade para a cidade que surge:

O termo cidade nova deve ser reservado às cidades que preenchem as seguintes condições: um esquema de urbanismo de conjunto, que dá à cidade sua unidade arquitetônica e faz dela uma entidade autônoma,

\footnotetext{
33 "Le caractère planifié de la ville nouvelle ou d'un ensemble urbain attire normalement un flux de population important dans un laps de temps limité. Une autre caractéristique des villes nouvelles est la nécessité de produire, en peu de temps, un stock important de routes, de réseaux divers et d'installations sociales."
} 
notadamente distinta dos assentamentos vizinhos; [...] um nível de equipamento suficientemente completo e uma identidade muito afirmada para que seus cidadãos se reconheçam eles mesmos como habitantes da cidade nova. (BLOC-DURAFFOUR, 1998, p. 88, tradução nossa). ${ }^{34}$

Independência física e cultural que se soma a uma independência econômica e política indispensável, como suscita o International New Towns Institute (INTI):

Cidades novas são assentamentos humanos fundados num certo momento da história por um ato explícito de vontade, de acordo com um plano precedente e objetivando sobreviver como uma comunidade local auto-sustentável e com governo local independente, capaz de desempenhar papel próprio no desenvolvimento de uma região na qual está localizado. (INTI, 2009, tradução nossa). ${ }^{35}$

Discurso similarmente pregado pelo governo iraniano ao estabelecer sua política de criação de CNs. Para ele, as CNs devem ter uma fundação econômica forte, visando a oferecer trabalho e atividades não apenas para sua população como para a população vinda de fora. Também deve ter identidade própria para atuar como polo num nível local e regional (IRAN, 1991).

Com isso, introduzo a síntese de Gideon Golany (1976) ao resumir CNs a partir de cinco elementos: 1) grau de autossustentabilidade; 2) comunidade balanceada; 3) diversidade de funções urbanas; 4) grau de independência política; e 5) tamanho.

\footnotetext{
34 "Le terme ville nouvelle devrait être réservé aux villes qui remplissent les conditions suivantes: un schéma d'urbanisme commun qui confère à la ville son unité architecturale et en fait une entité autonome, se distinguant notamment des localités voisines; [...] un niveau d'équipement suffisamment complet et une identité très affirmée pour que ses citoyens se reconnaissent comme des habitants de la ville nouvelle."

35 "New towns are human settlements founded at a certain moment in history by an explicit act of desire, according to a previous plan and aiming to survive as a self-sustaining local community with independent local government capable of playing its own role in the development of a region in which it is located."
} 
Embora ocorram essas oscilações conceituais - presença ou não de alguns elementos estruturais na definição de CNs -, podemos averiguar uma constância e, com isso, atribuir a esse tipo urbanístico uma unidade a ser particularizada na definição funcional. Unidade que permite a autores receitar o modo de construir uma CN, como faz Rassem Khamaisi (1998) ao propor CNs na Palestina. Segundo o manual estipulado pelo autor, esse empreendimento deve contar com: iniciativa e direção (órgão público especializado); planejamento (plano diretor participativo e flexível, aplicado em etapas); finanças (associação entre público e privado); terra (necessidade de grandes áreas de propriedade pública, mas com permissão de posse para setor privado - atrativo); implementação (governo central e governo local devem agir em conjunto, legislação, fase de desenvolvimento do governo local); e tamanho das novas cidades (resultante de um minucioso estudo de demanda esperada que permita as trocas de serviços e comércio, em torno de 100 mil habitantes).

Delimitações sínteses à parte, concomitantemente foram identificadas as definições fracionadas. Trata-se de olhares pontuais, focados sobre algum dos diferentes aspectos que qualificam as CNs. Estudos que as relacionam: às funções para quais foram criadas, num lado mais filosófico que descritivo; e às fórmulas baseadas no tamanho, na população e no tempo de desenvolvimento.

A diversidade dos princípios e dos objetivos que presidem a concepção de CNs direciona alguns especialistas a se aterem exclusivamente: ou à ordem urbanística (tamanho das cidades, agrupamento, localização, planejamento interno, modelos de habitações predominantes etc.); ou à ordem administrativa (natureza do empreendimento, relação com as coletividades locais); ou à ordem financeira (MERLIN, 1969a). Essa é uma diversidade presente "seja em períodos mais remotos ou mais recentes, e que só pode ser analisada caso a caso”, CN por CN, conforme declarou a historiadora do urbanismo Donatella Calabi (2008, tradução nossa). ${ }^{36}$

36 "Sia per i periodio più lontani che per quelli recenti, un discorso più articolato non può che essere fatto caso per caso [...]" 
Podemos verificar tal diversidade a partir das dezenas de denominações atribuídas e que conectam CNs: ao momento de sua criação (città di fondazione, cidade de nova fundação); ao querer (cidade de vontade, cidade querida, cidade encomendada, cidade plantada, cidade por decreto, introduced capital); a um ideal (cidades socialistas, Terra de Canaã); ao original (cidade partindo do nada, cidade nascida radicalmente nova, navyé goroda, new communities, nuevos pueblos); a um conhecimento (cidade planejada, cidade concebida, cidade inventada, cidade protótipo, cidade projetada); ao traçado (cidade nova aberta, cidade nova fechada, cidade regular, cidade traçada); ao sítio e sua localização (cidade ex nihilo, cidade surgida do nada, cidade-satélite, cidade-sputnik); e ao artificialismo (cidade de proveta, cidade objeto, cidade fabricada). Termos como modoun eg gegida (cidades novas), "utilizado para designar novas comunidades ou novos assentamentos, chamados oficialmente em árabe al tagamoh eg gegida" (JOSSIFORT, 1998, p. 40, tradução nossa). ${ }^{37}$

Uma profusão de terminologias que se intensifica conforme o país. Na França, por exemplo, identificam-se as villes nouvelles créées, ville créée, nouveaux villages, villes neuves e ville idéale (PANERAI et al., 1985).Uma multiplicidade nominativa que induz a uma discussão sobre a diferença entre villes neuves e villes nouvelles que, embora traduzidas como CNs para a língua portuguesa, não apresentam o mesmo significado em francês, ${ }^{38}$ porque "as palavras raramente são inocentes”, como pontuaram Philippe Panerai, Bernard Gendre e Anne-Marie Châtelet (1986, p. 5, tradução nossa). ${ }^{39}$

${ }^{37 “}$ [...] utilisé pour désigner de nouvelles communautés ou de nouvelles colonies, officiellement appelé en arabe al tagamoh eg gegida [...]."

${ }^{38}$ Segundo definição dada por Françoise Choay (1988), nouvelle refere-se àquilo que aparece pela primeira vez, um tipo novo (como as CNs do entorno de Paris, que surgiram como uma nova forma de expansão urbana). Diferencia-se, por suas características novas e inéditas, daquilo tido comumente por neuve, o que acabou de ser feito e ainda não foi utilizado ou o mais recente (em oposição ao velho, ao mais antigo). "Não somente nova (neuve), que denotará o frescor de uma criação ex nihilo, como em muitas cidades e novas vilas (Villeneuve) desde a Idade Média; mas nova (nouvelle), como a Nova Atlantis de Bacon, cujo atributo marca uma radical diferença” (CHOAY, 1988, p. 224, tradução nossa). Uma distinção que podemos traduzir, respectivamente, por cidade novidade e cidade nova.

39 “[...] les mots sont rarement innocents." 
A ambiguidade da expressão ville nouvelle deve-se a razões múltiplas. Segundo Pierre Merlin (1977), a expressão pode referir-se a uma função primária, ou seja, às CNs estratégicas (capitais federais ou estaduais); às CNs ligadas a uma atividade econômica (industrial, turismo, pesquisa etc.); às CNs integradas a uma grande aglomeração, a uma região urbana, buscando organizar seu desenvolvimento. Ville nouvelle tende a designar, também, a importância da operação: uma CN de dezenas de milhares de habitantes (ville neuve) não pode conter os mesmos serviços, equipamentos etc. de uma cidade de centenas de milhares de habitantes (ville nouvelle do entorno parisiense). Ainda, ville nouvelle concentra a ideia de localização, que não poderá ser a mesma de bairros novos, como os de Estocolmo e Amsterdã, que não têm vocação para serem cidades completas e, por isso, devem estar próximos ao centro da cidade-mãe (MERLIN, 1977). Por fim, a geógrafa Márcia Regina de Andrade Mathieu (2008) levanta, a partir de exemplos brasileiros, uma distinção entre villes nouvelles - cidades-satélites do Distrito Federal, como um tipo de expansão das grandes cidades e unidades urbanas economicamente autônomas -, e nouvelles villes - Brasília, como um tipo de cidade ideal.

Sutilezas nominais que demonstram a riqueza do tema ou um leque de significados que varia conforme os elementos compositivos das CNs, dentre eles a vontade em criá-las. Para o geógrafo Jean Brunhes, as CNs "nunca surgiriam sem que alguém as sonhasse e pusesse a seguir toda sua vontade criadora no trabalho de transformar em realidade o seu sonho” (apud TREVISAN, 2003, p. 142).

A iniciativa de criar uma CN é atribuída a diferentes agentes empreendedores, como expõem Françoise Choay e Pierre Merlin (2005). Pode partir tanto de uma empresa privada, como é o caso das new communities americanas, quanto de uma ação social e não lucrativa, como a da Fundação Habitacional (Asuntosäätiö), que empreendeu a construção de Tapiola (1952) e Kivenlahti (1965) na Finlândia. Pode também partir do poder público, seja pela coletividade local, como os novos bairros que constituem as periferias do pós-guerra das cidades holandesas, suecas e de algumas cidades alemãs, seja pelo governo maior, como os casos da União Soviética e Espanha. 
A União Soviética foi o primeiro país do mundo a lançar, após a Revolução de 1917, uma política de CNs em grande escala, como resultado da conjunção de um debate de ideias e de uma política de planejamento do território (MERLIN, 1992). Dessa ação, mais de mil exemplares de navyé goroda (cidades novas) surgiram.

Já os nuevos pueblos, uma das denominações para CNs na Espanha, foram implantados pelo regime ditatorial de Francisco Franco (1892-1975) entre 1936 e 1975. O programa de cidades novas rurais foi um dos mais ambiciosos e criticados planos de CNs no século XX (WEINER, 1981). Concebido pelo Instituto Nacional de Colonização espanhol, planejou e completou mais de 300 CNs entre 1942 e 1973.

Resultantes de uma ação privada ou pública, tais CNs também foram definidas a partir de outro elemento: o envolvimento de profissionais em sua concepção física. Nesse sentido, Donatella Calabi (2008) descreve os diferentes profissionais responsáveis por projetos de CNs ao longo da história. Os astrônomos na Antiguidade foram responsáveis por dominar a organização espacial dos astros e reproduzi-la, pela geometria, em comunidades terrenas. Racionalidade posteriormente adotada pelo clero, na Idade Média, e por engenheiros militares, no Renascimento, que tiraram partido da topografia para implantar suas fortalezas e suas cidades de defesa. Na Era Industrial, as cidades novas vão ser projetadas, principalmente, por engenheiros-arquitetos preocupados em separar as cidades pelo zoning e por normas edilícias como modo de controle da distribuição dos edifícios e de suas funções.

Além da presença de um savoir-faire, a professora também caracteriza a città nuova por sua localização, como um "assentamento surgido do nada em um território substancialmente não urbanizado” (CALABI, 2008)..$^{40}$ Sítios caracterizados por sua localização erma, como as regiões áridas propícias à “inseminação artificial” de novos centros de crescimento (SAFIER, 1977); por sua localização em áreas urbanizadas, como as villes nouvelles implantadas na região metropolitana de Paris; ou por sua localização rural, onde a ação humana se faz presente. Sítios onde o profissional irá traçar sua cidade seguindo referências ali presentes (campos

40 “[...] insediamento realizzato ex novo in un territorio sostanzialmente non urbanizzato." 
agrícolas, divisas, percursos, elementos naturais, estradas vicinais etc.), apropriação que Jean-Louis Cohen (2008) exemplifica pelos novos núcleos urbanos de colonização espanhola implantados sobre antigos assentamentos astecas no México, denominadas, por ele, de CNs pragmáticas.

Após identificação de possíveis lócus, as conceituações pontuais das CNs prosseguem, agora, por um viés funcional, ou uma "ênfase funcional determinada" (FIRMAN, 2004, p. 351, tradução nossa). ${ }^{41}$ Funções ligadas a um determinado momento histórico, como as CNs dos séculos XV e XVII, relacionadas às questões militares, ao desenvolvimento comercial, à ocupação de novas zonas agrícolas, à exibição de um poder soberano, ou a uma prática religiosa (CALABI, 2008). Funções que Michaël Safier (1977) amplia, registrando um nome e respectiva causa: “cidades de reinstalação” (divisão do país, guerra civil, perseguição de minorias, desastres naturais, exploração de recursos naturais em grande escala); “cidades-satélites” (realocação de população de grandes centros urbanos e problemas de moradia); e “cidades novas em sítio obrigado” (abrigar pessoal necessário à gestão e ao funcionamento de estabelecimentos industriais ou administrativos importantes para o plano da vida econômica e política de um país).

Especificamente na União Soviética, Anatole Kopp (apud MERLIN, 1975, p. 10) aborda a questão funcional por meio das cidades socialistas, que foram desenvolvidas em função: do anseio de desenvolvimento industrial, sobretudo em regiões não habitadas - 40\% foram construídas em sítio virgem -; da redistribuição populacional em escala regional, tornando-se cidades-satélites ao redor de grandes aglomerações; da modernização tecnológica do país - como Doubna, um centro tecnológico ao norte de Moscou; Zelenograd, um centro de pesquisa aplicada; e Akademgorodok, um centro científico.

Outro ponto de análise direcionada é o tamanho populacional. Para Françoise Choay e Pierre Merlin (2005), essa dimensão pode variar bastante conforme os exemplares analisados: de alguns milhares de habitantes (cidades de minério canadenses) a mais de um milhão em novas capitais ou em cidades industriais já desenvolvidas (Novosibirsk, na Rússia). O movimento cidade-jardim de Howard

41 “[...] determined functional emphasis [...]." 
previa, no entanto, um tamanho limitado (32 mil habitantes) e a comissão do New Town Act inglês (1946) recomendava entre 20 mil e 60 mil habitantes. Entre 1966 e 1975, a tendência (França, Reino Unido, Holanda, Suécia) estava em criar cidades novas maiores, de 100 mil a 500 mil habitantes. Uma variação de números, que, na maioria das vezes, modifica-se de acordo com o desenvolvimento apresentado pela CN após sua fundação, período no qual a CN se torna uma "cidade normal”, conforme intitulou Pierre Merlin e Michel Sudarskis (1991).

Tempo, entre a origem da CN e a "cidade normal”, ao qual outros autores se atêm para qualificar esse tipo urbanístico. Além do momento preciso de sua fundação, a pós-ocupação também serve de parâmetro para separar CNs e cidades de rápido crescimento, como colocou Nicole Haumont (1997a) ao analisar os exemplares poloneses: “Todas as cidades que têm crescimento rápido são cidades novas? [...] Na Polônia, existem 24 cidades de crescimento rápido, dentre elas somente 3 ou 4 correspondem à definição de cidade nova” (HAUMONT, 1997a, p. 84, tradução nossa). ${ }^{42}$ Para a autora, a diferença está na elaboração de um projeto de urbanismo e na data precisa de fundação das CNs de Jastrzebie, Nowa Huta e Nowe Tychy.

Ademais, estudos específicos sobre CNs revelam aspectos curiosos. Um deles (FIRMAN, 2004) traz o emprego do termo CNs em condomínios fechados de luxo na Indonésia. Esse marketing foi utilizado na região metropolitana de Jacarta, a partir de 1980, quando o governo local propôs essas “CNs” como espaços urbanos de segregação social, idealizados para oferecer segurança e para estabelecer um estilo de vida exclusivo (moderno) a seus habitantes.

Apropriação similar à realizada por Paul Delouvrier na França, ao optar pelo termo ville nouvelle em detrimento a centre urbain nouveau. Para atrair a atenção de novos moradores, traumatizados com os projetos dos grands ensembles (conjuntos habitacionais populares) dos anos 1950, a adoção de um novo nome permitiria o sucesso do empreendimento.

42 “Toutes les villes à croissance rapide sont-elles des villes nouvelles? [...] En Pologne, il y a vingt-et-quatre villes à croissance rapide, dont seulement trois ou quatre correspondent à la définition d'une ville nouvelle." 
Já no Canadá, algo mais intrigante ocorreu: o título de CN era dado após o aparecimento de moradores (BAILLY, 1972). As CNs da província de Alberta, no norte do Canadá, surgiram a partir da descoberta de petróleo na segunda metade do século XX e da exploração de recursos florestais e minerais, o que atraiu um grande contingente populacional para a região. Para contribuir com o crescimento planificado das comunidades petrolíferas, o governo de Alberta instituiu, em 1956, a “Lei sobre as cidades novas”. Não apenas essa medida legislativa favoreceu em 15 anos o surgimento de sete cidades petrolíferas, mas igualmente permitiu o desenvolvimento de cidades minerais, florestais e de aglomeração suburbana. A Lei de 1956 era bem simples: qualquer vila ou cidade cujo crescimento demográfico fosse muito rápido colocaria ao governo provincial sua candidatura a CN. A Comissão Provincial de Planejamento estudaria caso a caso e validaria com um relatório de recomendações. Com a candidatura aceita, o Departamento de Afazeres Municipais se ocupava dos problemas de planejamento da CN e nomeava um conselho de administração. Quando o crescimento e a situação financeira da cidade se estabilizavam, ela perdia seu status de CN para um status de cidade, de vila, ou de uma aldeia, conforme sua população.

Fosse marketing, fosse status, a recorrência às CNs se intensificou durante o século XX, período no qual o meio urbano foi escolhido como habitat do homem contemporâneo. Centenas e centenas de exemplares foram construídos, consolidando CNs como um tipo urbanístico, um modo de produzir espaços urbanos que vários estudiosos definiram cada qual à sua maneira: histórica, comparativa, sintética, fracionada e/ou pontualmente por meio de estudos de casos isolados. Um somatório conceitual para o qual pretendo contribuir ao definir CNs a partir de uma visão pessoal.

\section{Definição funcional}

Quase por encerrar essa etapa longa de nossa viagem, percorrendo os diversos conceitos atribuídos às CNs, peço um fôlego a mais aos leitores para que me 
acompanhem nos pensamentos e ideias expostos a seguir. Elucido a todos que se trata da definição funcional: uma conceituação particular construída para auxiliar a compreensão e a leitura das CNs nesta obra e em trabalhos futuros.

À maneira dos profissionais na virada do século XX, que transpunham vocábulos da medicina para o cerne arquitetônico e urbanístico (por exemplo: intervenção urbana, procedimento projetual, operação urbana, sutura/costura do tecido urbano etc.), como explanou a historiadora Maria Stella Martins Bresciani em palestra ministrada na École des Hautes Études en Sciences Sociales de Paris (6 de fevereiro de 2008), enveredo-me na área da ciência para dela subtrair alguns termos e aplicá-los na definição de CNs. Para enquadrar um núcleo urbano como uma CN, este deve conter traços do DNA ${ }^{43}$ pertinente a essa tipologia urbana. É no DNA da urbe que estarão todas as informações necessárias para a construção da imagem de uma CN. Tais informações serão fornecidas pelos genes, que, no caso das CNs, constituem-se por: desejo, necessidade, lugar, profissional, projeto e tempo. Assim, o DNA de CNs, para esta pesquisa, é formado por seis segmentos alinhavados pelo tempo histórico, cuja mutação pode ocorrer posteriormente conforme o desenvolvimento de pesquisas nessa área.

Contudo, antes de passarmos a um detalhamento maior desse mapa genético, há alguns pontos cujo esclarecimento é oportuno.

O primeiro diz respeito à relação entre CNs e tecidos urbanos existentes. Ao determinar que alguns planos de expansões urbanas qualificam núcleos consolidados como CNs (por exemplo: Santos, Nova York, Barcelona e Boa Vista), em função da proporção entre a área projetada e a área existente, julgo uma CN de expansão aquela cujo novo projeto seja duas vezes, ou mais, maior que a cidade antiga, receba o dobro da população presente, e que tal transformação proporcione uma nova identidade ao núcleo. Entretanto, devo salientar que nem todo ato de espraiamento da

${ }^{43}$ Segundo o sítio eletrônico <www.wikipédia.org>, "o ácido desoxirribonucleico (ADN, em português: ácido desoxirribonucleico; ou DNA, em inglês: deoxyribonucleic acid) é um composto orgânico cujas moléculas contêm as instruções genéticas que coordenam o desenvolvimento e funcionamento de todos os seres vivos [...]. O seu principal papel é armazenar as informações necessárias para a construção das proteínas. Os segmentos de ADN que contêm a informação genética são denominados genes” (Acesso em: 8 out. 2017). 
mancha urbana pode alterar o status de uma cidade de origem espontânea para uma CN. Muito menos que a área expandida seja entendida como uma cidade-satélite.

O bairro de Interlagos em São Paulo - proposto em 1933 como cidade-satélite pelo arquiteto francês Alfred Agache (1875-1959) -, os conjuntos habitacionais dos Institutos de Aposentadoria e Pensão (IAPs), o bairro da Barra da Tijuca no Rio de Janeiro - projetado por Lucio Costa em 1969 -, os condomínios fechados do tipo Alphaville em regiões metropolitanas, os bairros denominados oportunamente de Cidade Nova - como o bairro manauara Cidade Nova de Manaus -, as new towns in-town de Perloff e qualquer outro caso análogo, todos devem ser considerados como unidades urbanas de uma cidade e não CNs.

Não importa qual seja a dimensão ou o número populacional previsto, os exemplos citados não possuem a mesma essência, por exemplo, da cidade-satélite de Taguatinga (1958) e das demais cidades-satélites na órbita do Plano Piloto no Distrito Federal, nas quais há uma clara intenção de criar uma cidade como forma de crescimento urbano. Algo similar ao ocorrido em Paris que, antes das villes nouvelles da década de 1960, recebeu cidades e bairros jardins periféricos nos anos 1930 com o objetivo de oferecer moradias - episódio em que a distinção entre bairros e cidades foi exigência do poder público. Não devemos, portanto, confundir bairros, loteamentos, conjuntos habitacionais, unidades de vizinhança, regenerações urbanas, subúrbios, faubourgs com CNs.

Além dessa distinção, outro ponto refere-se à escala das CNs. Podemos considerar uma vila empresarial no meio da floresta amazônica como uma CN tanto quanto uma cidade construída para um milhão de habitantes nas estepes russas? Na maioria das ocorrências, as CNs são implantadas em áreas isoladas às cidades existentes, formuladas com dimensões de área e tamanho populacional variados.

Fisicamente, as CNs, como toda cidade, são compostas por dois elementos: vias e quadras - podendo as últimas ser divididas em lotes -, que são agenciadas para receber infraestrutura, construções e edificações que atenderão às necessidades de seus habitantes. A forma, seu traçado e seu tecido, ganham desenho a partir de 
condicionantes como o sítio, a função e os ideais de seu criador. Já suas dimensões podem variar conforme a densidade desejada, sendo mais compacta ou mais difusa. Para tal, dois fatores devem ser considerados: o contingente populacional previsto e sua disposição em edificações no espaço intraurbano. Obviamente, o número de habitantes influencia diretamente na dimensão física das CNs, mas seria ele também responsável por determinar aquilo que será ou não uma CN?

Cientes somos das inúmeras delimitações fechadas relacionando número de habitantes ao conceito de cidade. Parte delas define cidade como aquela que possui mais de 2 mil habitantes - tradição da Europa Ocidental -, enquanto outras elevam esse patamar para 20 mil - critérios da Organização das Nações Unidas. Estudiosos defendem que tal critério estatístico e conceituador deve ser estipulado segundo a realidade de cada país, podendo ser 250 habitantes na Dinamarca ou 2,5 mil a 9,9 mil habitantes para as towns ou acima de 10 mil para as cities norte-americanas. No Brasil, segundo órgãos competentes na área (Instituto Brasileiro de Administração Municipal - Ibam; Instituto Brasileiro de Geografia e Estatística - IBGE; e Sistema Nacional de Indicadores Urbanos - SNIU), a classificação é feita a partir da soma da população urbana e rural, sendo considerado município aquele que possuir mais de 2 mil habitantes. ${ }^{44}$

No universo das CNs, tal discussão se faz antiga. Platão, na Antiguidade, estipulou 25 mil a 30 mil habitantes para sua cidade ideal; Leonardo da Vinci, no Renascimento, previu um número aproximado de 30 mil habitantes para sua urbe; e Ebenezer Howard, em fins do século XIX, delimitou 32 mil - sendo 30 mil na zona urbana e o restante na zona rural - para sua cidade-jardim. No século XX, Le Corbusier e Lucio Costa chegaram a um denominador comum de 500 mil habitantes para, respectivamente, Chandigarh e Brasília, contrapondo-se às CNs empresariais africanas de Fria (Guiné, 1957) e Gamba (Gabão, 1969), projetadas para pouco mais de mil habitantes cada. Ademais, saliento que tais números imaginados são

${ }^{44}$ Em 2017, cerca de três em cada quatro municípios brasileiros apresentavam população abaixo de 20 mil habitantes (3.804 cidades num total de 5.570), num universo de 84\% da população brasileira estabelecida em zona urbana. Nesse sentido, temos $68,3 \%$ de brasileiros vivendo em cidades com menos de 20 mil habitantes (IBGE). 
em muito superados com o desenvolvimento das CNs: Goiânia (Goiás), projetada para 50 mil habitantes nos anos 1930, em 1960 já possuía população superior a 150 mil; ou, no sentido inverso, podem ficar aquém da expectativa: Águas de São Pedro (São Paulo), elaborada na década de 1930 para 10 mil habitantes, conta, atualmente, com pouco mais de 2,7 mil. Trata-se, pois, de uma variável instável, que não nos permite estabelecer indicadores conceituais de CNs.

Uma CN pode ter 1 mil ou 1 milhão de habitantes; pode se assemelhar a uma vila ou a uma metrópole; pode ser Belterra (1934), uma das CNs idealizadas pelo norte-americano Henry Ford (1863-1947) em plena floresta amazônica paraense, hoje com aproximadamente 16 mil habitantes; como pode ser Novosibirsk (1926), a CN industrial criada pelo georgiano Josef Stalin (1878-1853) na Sibéria, hoje com 1,5 milhão de habitantes. Seja qual for o número populacional, serão o contexto - a realidade - e a urbanidade o que nos permitirão qualificar uma CN como cidade.

Necessariamente, o isolamento de um núcleo urbano em um determinado território gera nele uma urbanidade. Para tal urbanidade, uma cidade deve apresentar, no mínimo, dois aspectos: possuir uma aglomeração de construções e revelar certos tratados sociais e atividades de relação. Essa urbanidade será responsável por permitir funções de troca, de confrontação e de encontros coletivos, dados num determinado espaço e suportados por uma estrutura equipada para armazenar e transmitir os bens materiais e culturais. No caso das CNs, essa urbanidade é artificial e intencionalmente colocada no momento de sua fundação para que possa atender à população recém-alojada e iniciar um processo de desenvolvimento próprio. Desse modo, todas as CNs, independentemente do número de habitantes e da dimensão física, devem apresentar, ao nascer, um espaço urbanizado que forneça condições necessárias às relações sociais e à interação socioambiental.

Por fim, devemos atentar para a questão político-administrativa. A falta de um poder público - prefeitura e câmara legislativa -, composto desde a origem de um núcleo urbano isolado, não necessariamente impede sua titulação de CN. Embora isso caracterize uma das principais diferenças entre uma cidade e uma vila 
ou um distrito, pode-se permitir uma flexibilidade temporal para que um núcleo urbano, sem governo em seus primórdios, seja considerado uma CN. Nos primeiros anos após a fundação, geralmente o papel administrativo fica a cargo da empresa empreendedora - como fez a Companhia Siderúrgica Nacional com Volta Redonda (Cidade do Aço) entre 1941 e 1968, ano de sua emancipação -, ou mesmo de uma cooperativa sem fins lucrativos - como em Letchworth, cuja gerência inicial coube à First Garden City Ltd. Somente após uma consolidação efetiva - econômica, social e urbana -, tal cidade adquire emancipação com a instauração do município, perdendo seu posto de povoado, de distrito, de vila. Com um governo local próprio, tal CN ganha sua independência - autonomia administrativa -, abrindo campo para o seu desenvolvimento. Tal processo pode ser verificado na história das CNs de Carajás (Pará, 1973) e Caraíba (Bahia, 1976), vilas operárias ligadas a empresas mineradoras e polos atrativos em suas regiões.

A partir desse panorama elucidativo - no qual distingo CNs de meras unidades urbanas, retiro o número populacional e a dimensão física dos seus critérios definidores, revelo a importância de uma urbanidade desde sua fundação, questiono a necessidade de uma autonomia administrativa original -, venho agora apresentar os atributos que, a meu ver, permitem identificar exemplares desse produto urbano.

Inicialmente, as CNs devem conter, em seu passado, um ambiente propício à sua criação. Um contexto, como vimos no capítulo anterior, composto por ideais, sonhos e desejos, somados aqui a conjunturas político-econômico-sócio-culturais favoráveis. Condicionantes que tornarão reais as utopias - utopias físicas -, verdadeiros retratos de determinados períodos históricos.

Na totalidade, teremos um quadro temporal abrangente, permeando períodos distintos e permitindo ao leitor compreender a evolução dessa tipologia urbanística feita a partir do “tempo de longa duração” (BRAUDEL, 1969), que nos possibilita analisar as transformações das estruturas que compõem as CNs ao longo dos séculos. Uma história em ritmo lento, que acolhe, em seu interior, os objetos escolhidos para serem narrados (CNs e seus atributos), levando em conta a marca de sua atração pelo todo. 
Dito isso, resgato a ideia de um DNA comum às CNs, que, necessariamente, deve ser composto por seis segmentos alinhavados por esse "tempo de longa duração”. Tais estruturas genotípicas, subsídios para a identificação de casos de CNs, correspondem a:

1. desejo: vontade do poder público e/ou da iniciativa privada em concretizar essas ações específicas;

2. necessidade: busca em atender, ao menos de início, a uma ou mais funções dominantes (administrativa, de colonização, ferroviária, de realocação, balneária, satélite etc.);

3. lugar: implantação num sítio previamente escolhido;

4. profissional: envolvimento de agente(s) definido(s) - eventualmente profissional(is) habilitado(s) - na sua elaboração física;

5. projeto: existência de um projeto urbanístico; e

6. tempo: presença de um limite temporal determinado, implicando, inclusive, um momento de fundação razoavelmente preciso.

Num primeiro instante, num sincronismo harmônico, três atributos surgem na origem da criação das CNs: o desejo de criá-las, a função para a qual foram inicialmente idealizadas e a escolha de um sítio específico para sua implantação.

O desejo - a vontade - de construir uma CN parte, como veremos em breve, de uma única pessoa ou de um grupo de pessoas apoiados por capital privado e/ou público, responsáveis por gerenciá-la antes, durante e logo após sua fundação. Diretamente relacionada está a função, a necessidade - política, econômica, social e cultural para qual o empreendimento é idealizado - cidades especializadas resultantes de um evento importante. Fechando essa cadeia preliminar está a escolha do sítio, atributo determinante para o surgimento da cidade, com influência direta nas suas atividades político-econômicas. Talvez o sítio seja o motivo que suscitou a iniciativa de sua criação - exploração mineral, entroncamento viário etc. -, ou que dará suporte àquilo 
desejado por seus criadores - por exemplo, defesa de território. Seja causa ou consequência, o sítio juntamente com o desejo e a função formam a base genética das CNs.

Figura 5: DNA

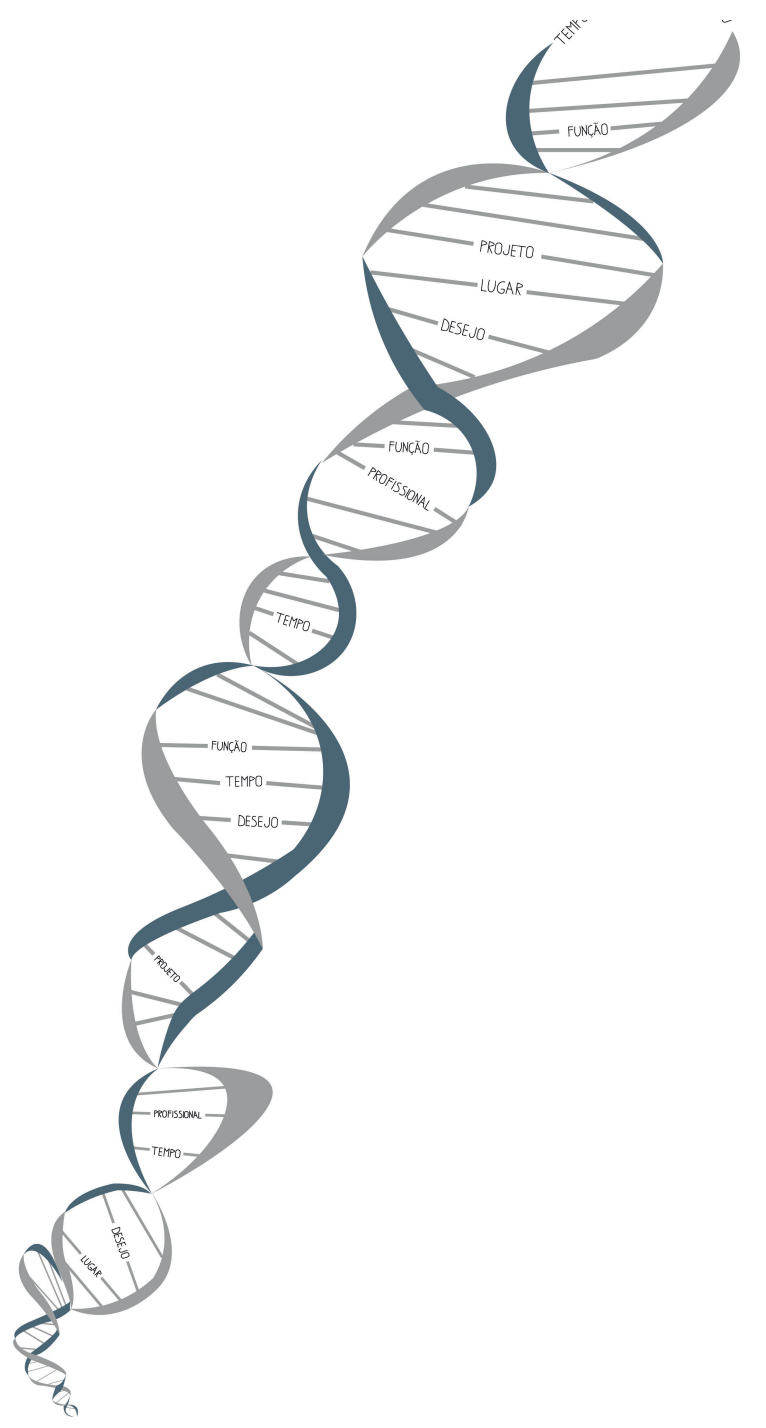


Da teoria à prática, da cidade premeditada à cidade real, entra(m) em cena o(s) profissional(is) que dará(ão) concretude à CN a partir da concepção de seu espaço físico, seja o traçado (vias, quadras e lotes), seja o tecido (parcelamento e edificações). Engenheiros, geógrafos, planejadores, agrimensores, topógrafos, arquitetos e urbanistas, entre outros, elaborarão um projeto para a cidade, com maior ou menor grau de detalhamento, que nos permitirá classificá-la segundo um tipo. O traçado e o tecido original permitem-nos visualizar os tipos urbanísticos e arquitetônicos em voga na época de sua materialização (Zeitgeist), além de identificar características peculiares (elementos fenotípicos).

Completando os cincos atributos está o tempo, o “tempo de curta duração”. Numa CN, o tempo é marcado por três fases: gestacional (decisão, projetação e construção); nascimento (ponto mais ou menos preciso de fundação); e desenvolvimento preliminar (um período curto de consolidação até atingir sua maioridade). Daí em diante, assim como no paradoxo nature versus nurture (natureza versus criação), as CNs podem adquirir vida própria e, eventualmente, deixarem de ser novas.

Por fim, a cadeia dos seis segmentos é combinada pela coluna-vertebral do DNA: o tempo histórico (“tempo de longa duração”). Primeiro, um tempo revelador das condicionantes político-econômico-sócio-culturais de cada época. Segundo, um tempo referencial da evolução histórica desse tipo urbanístico, sendo possível, a partir dele, visualizar as variações ocorridas no desejo, na necessidade, nos níveis de saber dos profissionais envolvidos, nos avanços tecnológicos que propiciam alterações nos tipos de projetos etc. Trata-se do tempo estruturador, unificador e diferenciador das CNs, a linha de constância do DNA.

Com isso, temos uma composição estruturada a fim de atender às necessidades momentâneas, sendo cada uma de suas frações isoladamente pinçada nos próximos capítulos (as paradas), devidamente conceituadas e exemplificadas por estudos de casos nacionais ou internacionais. 


$$
y
$$




\section{Cidades novas e o desejo}

Primeira parada: alguma cidade no interior do estado de São Paulo, com baldeação para o norte paranaense.

A Paulista, da Companhia Paulista de Estradas de Ferro (1872); a Mogiana, da Companhia Mogiana de Estradas de Ferro (1872); a Sorocabana, da Estrada de Ferro Sorocabana (1875); a Araraquarense, da Estrada de Ferro Araraquarense (1895); a Noroeste, da Estrada de Ferro Noroeste do Brasil (1905), e respectivos entroncamentos, como Ourinhos-Umuarama no Paraná (1920) - seja qual for a ferrovia escolhida, esteja preparado para encontrar dezenas de CNs.

Implantada a partir da capital paulista, ultrapassando os limites administrativos conforme a expansão de sua franja, essa malha ferroviária mimetiza-se em um processo inédito de urbanização da hinterlândia - um território até então pouco explorado, coberto pela Mata Atlântica e povoado por tribos indígenas (ANDRADE, 1945). Uma urbanização construída pela criação de novos núcleos, empreendidos pelo desejo do poder público ou da iniciativa privada. Obras intencionadas, visando a subsidiar a economia do café no último quarto do século XIX e, simultaneamente, a respaldar o processo de colonização e ocupação de novas fronteiras durante o século XX.

Originária do Rio de Janeiro - início do século XIX -, a cafeicultura teve o estado de São Paulo como palco principal para o seu desenvolvimento. O cultivo do café em solo paulista partiu da divisa com o Rio de Janeiro, passando pelo Vale do Paraíba e avançando para o oeste (década de 1860) - rumo às terras virgens do planalto -, chegando ao norte do Paraná, sul de Goiás e do Mato Grosso já no século XX. 
Esse modelo de economia agroexportadora, ${ }^{1}$ diferentemente dos anteriores (exploração da cana-de-açúcar, de minério e mesmo borracha), que utilizavam as cidades apenas como entrepostos de suas produções, introduziu novos aspectos no cenário produtivo nacional. Apesar de basear-se na zona rural, a cafeicultura proporcionou a origem de uma nova relação entre campo e cidade (SINGER, 1973; CANO; 1998). Para se tornar produtiva, a lavoura de café necessitava de um período de cinco a seis anos de espera - período que o produtor passava sem obter retorno lucrativo -, ao mesmo tempo em que precisava de capital para abrir novos cafezais. Como solução, obrigava-se a fazer empréstimos e financiamentos de capital - inexistentes no país na quantidade necessária - diretamente com bancos estrangeiros, principalmente ingleses, que começavam a instalar filiais na capital da província.

Esta nova relação campo-cidade ainda era fomentada por uma reversão dos lucros, obtidos pela oligarquia agrária no campo, em melhorias urbanas - portos, armazéns, transportes e comunicações bem como aquelas inerentes à própria urbanização -, em virtude da necessidade do produtor de utilizar também o espaço urbano para que o beneficiamento - modo de produção mecanizado - do café ocorresse, gerando novas ofertas de emprego e incentivando novas técnicas produtivas.

Além disso, a cafeicultura também corroborou, no estado de São Paulo e em estados vizinhos, o surgimento de uma coesa malha de ferrovias que ligava as zonas produtivas às principais cidades do estado, patrocinada não apenas pelo poder público, mas pelos ricos fazendeiros (CANO, 1998). De um lado, a modernização dos meios de transportes em solo paulista permitiu, num primeiro momento, a redução de custos com o escoamento da produção desde a lavoura até o porto de Santos, e, num segundo momento, a criação de uma densa rede urbana, formada por dezenas de CNs surgidas a partir de cada ponto de parada do trem (MONBEIG, 1984).

1 Resumidamente, compunham o complexo cafeeiro: a atividade produtora de café; a agricultura produtora de alimentos e matéria-prima (para subsistência ou comércio); a atividade industrial (produção de equipamentos de beneficiamento de café visando ao aumento da produtividade); indústria de sacarias de juta (para embalagem do café e demais compartimentos produtivos da indústria); a implantação e desenvolvimento do sistema ferroviário (reduzir custos com transporte); a expansão do sistema bancário (financiamentos); e a atividade do comércio com importação e exportação (CANO, 1998). 
Embora não tenha financiado diretamente as ferrovias, o poder público lançou ações paralelas que corroboraram a transformação urbana dessa região. O governo paulista, por exemplo, foi responsável pelo financiamento subsidiado imigratório, permitindo a entrada de 1,2 milhões de pessoas no estado, como também tomou a iniciativa de instituir "núcleos coloniais de imigrantes" para a agricultura de subsistência e de distribuir glebas de terras devolutas (no sertão ocidental paulista) para a expansão cafeeira, afirmando a importância do campo na economia estadual e nacional (CANO, 1998).

O objetivo do poder público era criar mecanismos de distribuição do contingente populacional, excedente na capital paulista, pelo interior. Nesse sentido, Maria Alice Rosa Ribeiro (1991), em História sem fim: inventário da saúde pública - São Paulo 1880-1930, relata um breve caso de manipulação da massa operária frente aos interesses públicos:

O DET [Departamento Estadual de Trabalho] e a Comissão de Socorros propuseram o combate ao "pernicioso urbanismo" através da concessão de todas as facilidades para os desempregados que se dispuseram a ir procurar emprego no interior. Desurbanizar a Capital, levar a massa de ociosos para o interior foi a medida tomada sob o comando do DET e do seu órgão, especialmente voltado para a questão do mercado de trabalho - a Agência Oficial de Colocação. Cartazes anunciando as facilidades e as concessões dadas pelo governo foram espalhados em diversos pontos de concentração de imigrantes e de desempregados. (RIBEIRO, 1991, p. 181-182).

Esse caráter antiurbanista, indicado pela autora como recorrente já na década de 1910, seria retomado no governo de Getúlio Vargas, durante o Estado Novo (19371945), pelo programa “Marcha para o Oeste” (1938). O slogan nacionalista, mais do que expressar a tomada do continente mediante sua ocupação e colonização, 
permitia ao governo aliviar as tensões e os conflitos sociais existentes nas grandes cidades. Para o Estado, a criação de CNs incentivaria ou instigaria o imaginativo dos mais aflitos a começar uma nova vida, teoricamente em melhores condições.

Com a derrocada do café nos anos 1920, o impulso à industrialização e, consequentemente, à urbanização alinhava-se ao empenho governamental em promover a interiorização do país e em reforçar as defesas de nossas fronteiras, como o próprio presidente Vargas afirmou na época:

[...] a civilização brasileira, à mercê dos fatores geológicos, estendeu-se no sentido da longitude, ocupando o vasto litoral, onde se localizavam os centros principais de atividade, riqueza e vida. Mais do que uma simples imagem, é uma realidade urgente e necessária galgar a montanha, transpor os planaltos e expandir-nos no sentido das latitudes. Retomando a trilha dos pioneiros que plantaram no coração do Continente, em vigorosa e épica arremetida, os marcos das fronteiras territoriais, precisamos de novo suprimir os obstáculos, encurtar as distâncias, abrir e estender as fronteiras econômicas, consolidando, definitivamente, os alicerces da nação.

O verdadeiro sentido de brasilidade é a marcha para o Oeste. No século XVII, de lá jorrou o caudal de ouro que transbordou na Europa e fez da América o Continente das cobiças e tentativas aventurosas. E lá teremos de ir buscar: dos vales férteis e vastos, o produto das culturas variadas e fartas; das entranhas da terra, o metal com que forjar os instrumentos de nossa defesa e do nosso progresso industrial [...]. (apud NEIVA, 1942, s.p.).

Com essa iniciativa de colonizar regiões com baixíssima taxa de ocupação e expandir internamente o mercado econômico do país, o propósito do governo 
Vargas era iniciar um processo de inversão na relação de dependência entre campo e cidade. O modelo econômico nacional, baseado tradicionalmente na monocultura agroexportadora, cedia espaço para um novo e mais atraente: o industrial. Dessa forma, a importância do meio rural enquanto espaço do processo de produção retraía, ao mesmo tempo em que a importância do meio urbano, devido à estrutura do processo industrial, se expandia de forma acelerada. A instalação de uma rede urbana - inexistente até então - propiciaria espaço físico para a implantação de indústrias, criaria um mercado consumidor para os produtos fabricados nos grandes centros industriais, além de servir de entreposto e de fornecedora dos produtos agropecuários - matéria-prima para as indústrias - cultivados na zona rural.

Territorialmente, o país não apresentava uma ocupação homogênea. Por questões político-econômicas, a urbanização brasileira, até o século XIX, foi contida em sua linha litorânea, sendo insignificantes as exceções: algumas vilas pombalinas e outras geradas ao longo do ciclo mineral no século XVIII (MARX, 1980). O restante do país se encontrava intocado e com suas divisas desprotegidas em relação aos países limítrofes à sua face oeste. Ocupar o interior, rumo ao ocidente, facilitaria ao governo se apossar de seu território como um todo e garantir tanto a proteção do espaço nacional quanto expandir a rede urbana.

A rede ferroviária, nascida com a cultura do café, passaria agora a contribuir no processo de ocupação do território. Ao longo das linhas férreas, companhias privadas - retalhadoras de terras - ou os donos de imensas glebas loteavam suas terras e as vendiam aos "pioneiros” que vinham do Leste (MONBEIG, 1984). Áreas antes cobertas por florestas cederam lugar à lavoura e à criação de gado, na época presentes em fazendas, sítios e chácaras, atendendo às necessidades do mercado nacional e internacional e contribuindo para a economia estadual. Assim, simultaneamente à introdução da ferrovia e à ocupação de áreas rurais, começaram a despontar cidades como centros de apoio à população residente na região. Núcleos urbanos regularmente implantados, como descreve Murillo Marx em seu livro Cidade brasileira (1980): 
A vigorosa marcha dos cafezais para o oeste promove centenas de novas fundações em São Paulo, Paraná e Minas. As matas virgens cedem lugar a fazendas e povoados. Uns e outros vão retalhar a terra roxa, tendo em vista as peculiaridades geográficas e as vantagens da comercialização das glebas e dos lotes urbanos. O tipo de sítio disponível, numa paisagem muito homogênea, o trem, novo meio de transporte com suas exigências de trajeto, e a rápida divisão e venda dos terrenos geram uma cena urbana nova, monotonamente repetida e regular. (MARX, 1980, p. 36)

Figura 6: Andradina

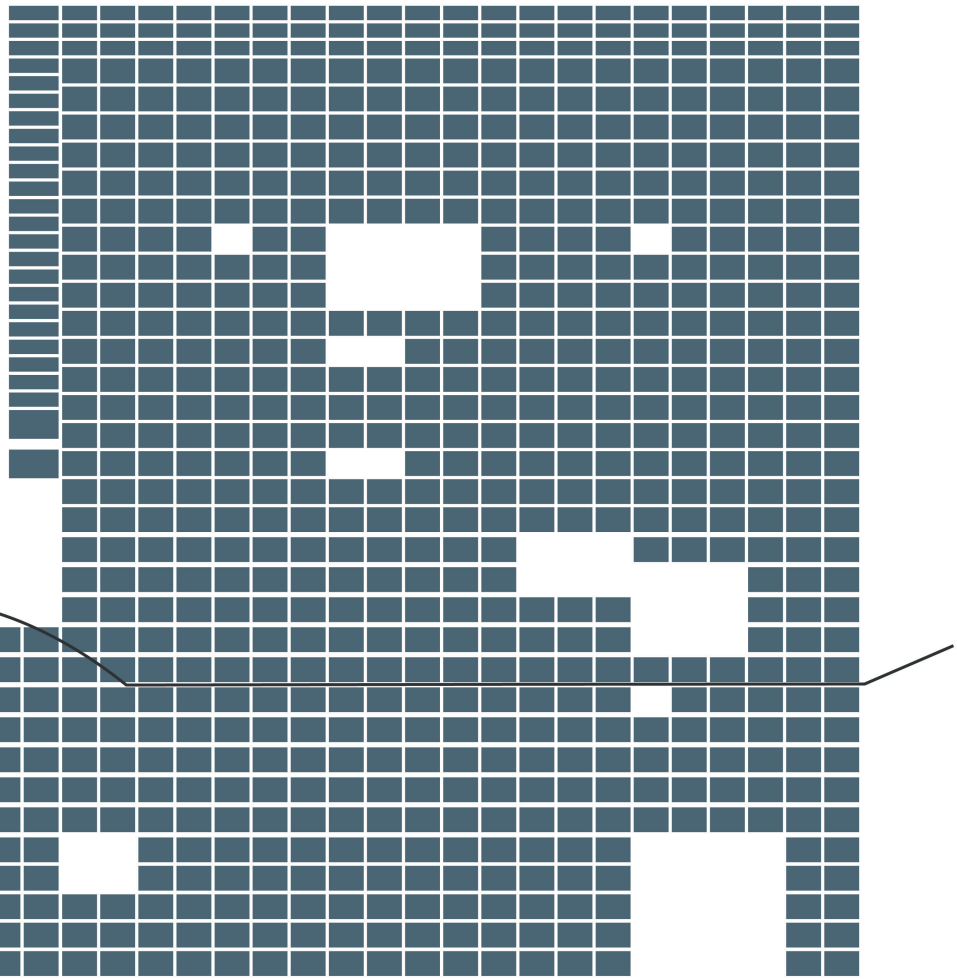


Urbanisticamente e diferentemente dos tipos embelezador e de melhoramentos que vinham sendo praticados nos grandes centros urbanos do país, o traçado dessas cidades de colonização e expansão territorial apresentava a regularidade e a homogeneidade como marcas (BRUAND, 1991), principalmente devido ao sítio plano e à rapidez necessária para sua implementação, como sucedido nas paulistas: Franca (1921), Jales (1928), Tupã (1929), Andradina (1932), Adamantina (1939), além de Londrina (1929) e Arapongas (1935) no estado do Paraná. Traçados que se contrapunham a alguns tipos dotados de projetos urbanísticos mais apurados com adequação ao sítio, arborização, zoneamento complexo, saneamento etc. -, como Luiziânia (1941) e Panorama (1952) em território paulista, e Maringá (1945) e Cianorte (1955) em terras paranaenses. No conjunto, eram CNs projetadas por topógrafos, agrimensores, engenheiros e/ou arquitetos, financiadas por companhias privadas ou iniciativas individuais com o intuito de especular a terra agrícola.

Exemplo disso foi a ação empreendedora da Companhia de Terras Norte do Paraná - de capital inglês -, que assentou linhas de transporte e negociou terras no seu trajeto, planejando localidades com zonas suburbanas e cinturões verdes a cada 15 ou 12 quilômetros sobre a ferrovia (REGO, 2009). Tal planejamento, a partir de 1925, contava com um plano específico de divisão das CNs em três graus de importância e tamanho, como aponta Rosana Steinke (2002, p. 214):

As maiores eram denominadas cidades-polo, distribuídas a cada 100 quilômetros umas das outras e previstas para comportar um número maior de habitantes, ainda que não obrigatoriamente o mesmo para todas, sendo que algumas tinham a previsão de até 200 mil pessoas. Estas deveriam ter uma rede de comércio e serviços bem estruturada, capaz de atender a toda a região por ela compreendida. A segunda categoria de cidades novas era formada por núcleos urbanos de tamanho médio, com comércio de menor porte e alguns serviços mais restritos, podendo abrigar um número 
entre 10 mil e 20 mil habitantes. A terceira forma de assentamento criada tinha uma população bem menor, em torno de 5 mil habitantes, denominado de "patrimônio", formando a última tipologia de uma rede hierarquizada.

A regularidade dessas cidades dispostas ao longo da linha férrea permite-nos fazer um paralelo com o tipo de Cidade Linear $^{2}$ do espanhol Arturo Soria y Mata (1844-1920). Em ambos os casos, é possível verificar a presença da ferrovia como elemento estruturador da escala urbana e regional. Se, no caso espanhol, a ideia de expansão urbana foi trabalhada via linha férrea interligando duas cidades existentes, nas CNs do oeste paulista e norte paranaense a implantação de cada cidade era gerenciada pela ferrovia e suas estações - quase sempre equidistantes uma das outras. Do mesmo modo, podem-se fazer relações dessa produção urbanística com o tipo de rede de cidades apresentadas por Ebenezer Howard em sua cidade-jardim (1898) como forma de expansão urbana e distribuição populacional mediante a inserção de um novo núcleo - superando em três décadas as cidades-satélites de Londres -; ou com o Movimento Americano Anti-urbanista, em que o arquiteto-protagonista Frank Lloyd Wright (1867-1959) apresentou a negação da cidade mediante a interiorização dos Estados Unidos da América pela divisão do território em inúmeras propriedades rurais abastecidas por autovias ou pelo transporte aéreo individual.

Urbanização linear pelas ferrovias, cidades-satélites da capital paulista, tipo antiurbanista, ou mesmo um planejamento regional, como defendia Patrick Geddes (1854-1932) em sua obra Cidades em evolução de 1915. Seja qual for sua caracterização e aproximação teórica, o processo de ocupação e urbanização dessa região, iniciado nas primeiras décadas do século XX e intensificado entre os anos 1930

2 No ano de 1882, em artigo publicado pelo jornal de Madri El Progresso, Soria y Mata divulgou seus ensaios para a criação de uma cidade ideal: a Cidade Linear. A proposta referia-se à distribuição de um assentamento ao longo de uma linha desenhada acompanhando o sistema de circulação adotado:o transporte ferroviário. A cidade se estruturaria a partir da linha férrea, crescendo linearmente sem limites e de forma organizada, sendo uma resposta à expansão irregular das cidades existentes e um modo de não desconfigurar ou destruir os centros históricos das grandes cidades. 
e 1950, gerou dezenas e dezenas de CNs. Esse, um processo resumido por Pierre Monbeig (1984, p. 23) no seguinte relato:

Tudo se passa como se este país conhecesse em 75 anos, um século no máximo, o que se levou milênios para fazer na Europa. E certamente é isto: nascimento e formação da paisagem rural, fundação e crescimento das cidades, construção duma rede de comunicações, mistura de raças, elaboração de uma mentalidade regional.

CNs fundadas no interior dos estados de São Paulo e Paraná, intencionadas pelo desejo do poder público ou pela iniciativa privada, para auxiliar na produção cafeeira ou na ocupação de terras ermas, estrategicamente posicionadas ao longo das linhas férreas, traçadas por técnicos e/ou graduados num curto período da história de nosso país. CNs não integralmente exibidas, mas contextualizadas a fim de revelar o primeiro segmento de seu DNA: o desejo.

Tanto governos estaduais como federal administraram as ações que confluíram para o estabelecimento de tal cenário urbano. Uma postura empreendedora fomentada por ações privadas - fossem coletivas, fossem individuais -, economicamente ativas, que viram na criação de CNs a oportunidade de expandir seus investimentos, aplicando capital excedente, e de obter lucros antes inimagináveis. Um simples retrato da necessidade da figura empreendedora na concepção das CNs.

\subsection{Empreendedores}

Se as CNs têm genitores, estes são seus empreendedores. Enganados estamos ao acreditar que os pais das CNs são seus projetistas (arquitetos, engenheiros, topógrafos etc.), coadjuvantes no processo de construção de uma nova cidade. Os verdadeiros protagonistas são aqueles agentes detentores do desejo, da intenção, da ideia inicial em criá-las. As CNs tornam-se crias não do acaso, mas de um querer; nascem em virtude 
do interesse e da vontade de um indivíduo ou de um grupo deles que, possuidores de capital público ou privado, conseguirão empreender sua construção.

Todos os predicados utilizados para relacionar criador e cria remetem-nos a uma aspiração humana diante de algo esperado. Nesse sentido, as CNs correspondem aos anseios de seus idealizadores, são a materialização de um desígnio, seja ele a representação física do poder, a constituição de uma fonte lucrativa ou a solução para um determinado problema.

As CNs são, a seu título, o equivalente da visão espacial dos projetos dos Estados e dos projetos de uma sociedade. Além de refletir as ideologias do momento, revelam os protagonistas do projeto, geralmente monarcas e chefes de Estado, comunidades locais organizadas, grupos ou indivíduos portadores de uma utopia ou por necessidade.

Para alguns autores, como Nadir Boumaza et al. (2006, p. 523, tradução nossa), ${ }^{3}$ os projetos de CNs não passam de uma "marca da ação de poder e coletividade desde a antiguidade traduzindo o desejo dos homens de fabricar eles mesmos sua cidade à maneira de seus ideais e fantasmas, de seus desejos e necessidades”. No mesmo raciocínio, Michaël Safier (1977) defende que as CNs são personificações do poder, uma tentativa enorme de publicar um manifesto ideológico feito de asfalto, concreto e vidro. Para Patrick Boucheron, as CNs não passam de "cidades de fundação e esta fundação é, por definição, um gesto político” (BOUCHERON, 2002, p. 266, tradução nossa). ${ }^{4}$

Nos primórdios, a origem de uma CN esteve ligada à vontade de um príncipe ou de um general conquistador, buscando marcar o tempo e o espaço via a construção de uma cidade representativa e dotada de ordem e de civilização. Curiosamente, isso fica nítido na nomeação dada a algumas, quando o fundador empresta seu nome ao novo núcleo para consubstanciar sua ideia dominante. O diplomata José Osvaldo de Meira Penna menciona tal recorrência em sua obra Quando mudam as capitais:

3 “[...] marque de l'action du pouvoir et de la collectivité depuis l'Antiquité, traduisant le désir des hommes de construire leur propre ville à la manière de leurs idéaux et fantômes, de leurs désirs et de leurs besoins [...]"

4 “[...] villes de fondation et cette fondation est, par définition, un geste politique [...]” 
Akhetaton está indissoluvelmente ligada à memória de Akhenaton, o faraó herege [...]. Alexandria, capital do Egito ptolomaico, foi a mais ilustre das metrópoles que o conquistador macedônio Alexandre espalhou a granel, no passo de suas conquistas extraordinárias pela Ásia ocidental. Bizâncio, consagrada como a Segunda Roma, perdeu o nome de seu fundador, Bysas, para receber o de Constantino. São Petersburgo é a cidade de Pedro, o Grande. (PENNA, 1958, p. 26)

Figura 7: Karlsruhe

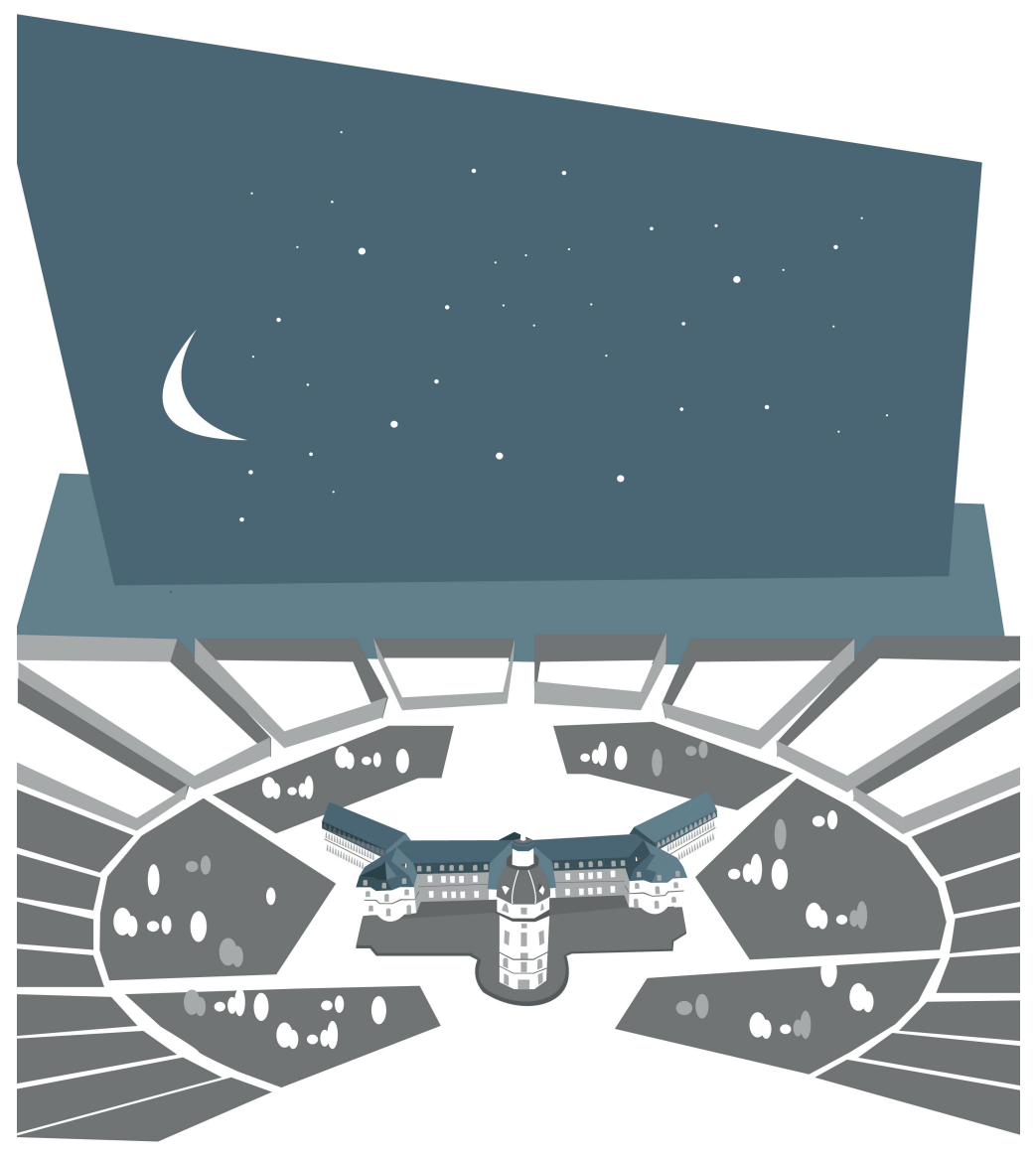


No absolutismo europeu do século XV ao XVIII, poder e CNs são novamente associados. O urbanismo e a arquitetura monumentais de Versalhes na França (1664) ou de Karlsruhe na Alemanha (1715) expressam realisticamente a força monárquica desse período. O artifício patte-d'oie - três vias confluentes, neste caso, para a entrada do castelo - foi aplicado para estruturar e organizar ambos os assentamentos, um traçado de vias cujo enquadramento foi garantido por edificações com gabarito e fachadas normatizadas. Um cenário meticulosamente projetado a fim de simbolizar o poder soberano (PANERAI; GENDRE; CHATELET, 1986).

Em tempos modernos, a simbologia de poder no tecido urbano das CNs é posta em prática mediante duas possibilidades: uma pautada na fundação de inúmeras cidades visando à ocupação de um território, demonstrando domínio - posse - sobre ele; a outra, direcionada à criação de novas capitais, sedes administrativas de uma região ou de um país.

A primeira possibilidade engloba uma escala mais abrangente, necessariamente envolvendo uma política de planejamento regional (MERLIN apud BOUMAZA et al., 2006), cujo objetivo primordial é ocupar e colonizar terras ermas, a exemplo do ocorrido no Brasil com a política pombalina a partir do século XVIII e as ações na franja pioneira paulista e paranaense durante o século XX. É em cenários assim que o setor privado - cooperativas, empresas, companhias, ou mesmo indivíduos ricos -, sustentado por iniciativas do poder público, aplicará seu capital na fundação de cidades - de tentativas isoladas a parcerias com órgãos estatais em políticas de desenvolvimento e integração nacional, o espectro de atuação do setor privado qualifica-o como um dos principais agentes responsáveis pela construção de novos assentamentos.

Já a segunda possibilidade, passível de enquadramento numa política de planejamento regional, ocorre pontualmente na figura de CNs administrativas, símbolo do poder e da ordem de uma região (GORDON, 2006), como em Minas Gerais (Belo Horizonte, 1893), em Goiás (Goiânia, 1933), em Roraima (Boa Vista, 1944), nos estados indianos de Punjabi e Haryana (Chandigarh, 1952), em Tocantins (Palmas, 1989), ou em uma nação, como fica exemplificado nas novas capitais dos Estados 
Unidos da América (Washington, 1791), da Austrália (Canberra, 1908), da Turquia (Ankara, 1923), Índia (Nova Délhi, 1929), Paquistão (Islamabad, 1958), Nigéria (Abuja, 1976), Costa do Marfim (Yamoussoukro, 1983) ou Cazaquistão (Astana, 1997). Seja qual for a escala de abrangência, tais cidades tornam-se representações de uma visão uniforme dos princípios de ocupação do espaço, refletindo, em seu traçado e em sua arquitetura, o poder sobre elas estabelecido.

Economicamente, as CNs servem como instrumentos de multiplicação do capital. São tidas como investimentos diretos e indiretos na obtenção de lucros por seus empreendedores. Diretos, quando são planejadas para a comercialização da terra recém-urbanizada; indiretos, quando esses núcleos servem apenas de base para outras atividades econômicas - exploração de jazidas minerais, por exemplo. Nesse sentido, as CNs são consideradas como respostas otimistas a períodos particulares de desenvolvimento (CHALINE, 1985), como soluções para catástrofes ambientais (ROUAT, 1996), como abrigos para refugiados de guerras (AGIER, 2001) ou como ações políticas de desenvolvimento econômico e de planejamento de todo o território nacional em países em desenvolvimento (MERLIN, 1977).

No geral, os motivos de conjuntura política e econômica despertam em indivíduos, sejam eles da esfera pública, privada ou de ambas - em parceria -, o querer, a intenção, o desejo em criar cidades. Cidades como produtos bem particulares das condições de lugar, de tempo, dos meios de ação pública e privada e, enfim, da presença de uma clientela socioeconômica, como salientam Jackie Poitevin, Bernard Etteinger e Gilles Antier (1993).

São produtos com a marca de seu produtor. Vejam-se: 1) Washington (1791), cujo obelisco central do Mall comemora o general George Washington (1732-1799), vitorioso e estadista austero a quem os Estados Unidos da América devem sua independência; 2) Pretória (1860), a capital administrativa da República da África do Sul, que celebra Andries Wilhelmus Jacobus Pretorius (1798-1853), o maior bandeirante bôer; 3) Marília (1923), no estado de São Paulo, cujo nome provém de uma regra da Companhia Paulista de Estradas de Ferro em nomear seus ramais (cidades) por 
ordem alfabética; 4) Londrina (1929), uma referência a Londres feita pela empresa de capital inglês Companhia de Terras Norte do Paraná; 5) Junqueirópolis (1945), a CN paulista que recebeu o sobrenome de seu empreendedor, Álvaro de Oliveira Junqueira; e 6) Sinop (1974), no estado do Mato Grosso, sigla para Sociedade Imobiliária do Noroeste do Paraná, responsável pela sua construção. CNs cujos nomes são testemunhos de suas criações, fazendo referências diretas a seus criadores.

\section{Poder público e suas cidades novas}

Uma CN, segundo a definição do arquiteto Ervin Y. Galantay, é uma comunidade planejada e conscientemente criada como resposta clara a objetivos estatais. Tal criação urbana pressupõe, parafraseando o arquiteto, a existência de uma autoridade ou uma organização suficientemente poderosa para assegurar o sítio - recursos primários para seu desenvolvimento - e para exercer controle contínuo até que a cidade atinja tamanho viável (apud WEINER, 1981, p. 394).

A realização de CNs é uma operação pesada - infraestrutura, logística, capital envolvido etc. -, que demanda do Estado e seus órgãos competentes um trabalho de planejamento, de execução e de monitoramento. Para Pierre Bloc-Duraffour (1998), será o Estado o responsável por: fixar um quadro legislativo, que prevê o financiamento e aprova o plano; definir os projetistas; incluir operadores privados; e oferecer o título de município ao recém-inaugurado assentamento.

Além das ações previstas no processo, o Estado age em tempos precisos da história em função de necessidades momentâneas. Foi assim na França durante a Guerra dos Cem Anos com a Inglaterra (1337-1453). A disputa por terras continentais levou a monarquia francesa a pulverizar centenas de bastides (cidadelas fortificadas) em sua costa oeste; mesma ação adotada pelos ingleses ao conquistar terras francesas. As bastides eram pequenos núcleos regularmente traçados ao redor de uma praça, que, além da função defensiva, serviam como entrepostos comerciais (PANERAI et al., 1985). 
A conquista por território - defesa de fronteiras, colonização de regiões desabitadas, expansão agrícola etc. - também foi uma preocupação estatal na primeira metade do século XX: veja-se a “Marcha para o Oeste” de Vargas (1930-1945). Governos de diversos países convergiram esforços para o planejamento do território a partir de um ou vários projetos especiais, divididos em quatro categorias por Michaël Safier (1977):

1. programas de planejamento rural (repartição de serviços que auxiliem o planejamento de comunidades rurais e melhoramento da agricultura);

2. programas de planejamento de recursos regionais (infraestrutura necessária para a execução de grandes projetos visando a uma exploração futura, como hidroelétrica ou jazida mineral);

3. programas de planejamento industrial (implantação equilibrada sobre o território); e

4. programas de planejamento urbano (descentralização das atividades presentes nas grandes cidades em favor de uma rede mais racional na repartição de empregos, moradias, equipamentos e meios de transportes).

Para o autor, "cada um destes programas governamentais deu origem a uma cidade nova bem particular” (SAFIER, 1977, p. 4, tradução nossa) ${ }^{5}$ - cidades empreendidas por um Estado totalitário e centralizador, como na URSS de Stálin (1922-1953), na Itália de Mussolini (1922-1943) ou na Espanha de Franco (19361975); ou por um Estado provedor e desenvolvimentista, como nos Estados Unidos da América de Roosevelt (1933-1945). Em ambos os casos, as CNs tornaram-se instrumentos criados em razão de ações políticas.

Na União das Repúblicas Socialistas Soviéticas (1922-1991), a organização da planificação urbana foi fundada pelo poder central sobre a articulação de planos em diferentes escalas, coordenados e impulsionados pelo Gosgrajdanstroj ou GOSSTROI - espécie de Ministério da Construção. Este dispôs institutos de pesquisa 5 “[...] chacun des programmes gouvernementaux a donné lieu à une nouvelle ville très particulière [...]” 
e de planificação em cada uma de suas Repúblicas. A localização precisa de cada CN era determinada pela direção de planejamento do território em acordo com órgãos locais de administração. Cada CN teria seu próprio Plano Diretor, estabelecido por um dos institutos e aprovado pelo Comitê de Estado para Construção (MERLIN, 1992).

Essa política foi conduzida por duas preocupações gerais, ambas atreladas a questões econômicas. De um lado, buscava-se harmonizar a repartição da população em função da natureza dos recursos e disponibilizar, ao mesmo tempo, um bom número de serviços, em que a "elaboração de um esquema geral de povoamento da URSS seria a verdadeira chave para o desenvolvimento e para criação de aglomerações” (BEAUJEU-GARNIER et al., 1982, p. 732, tradução nossa). ${ }^{6}$ Por outro lado, pretendia-se: evitar a anarquia do crescimento urbano, limitando o tamanho das grandes cidades; desenvolver a industrialização, sobretudo em pequenas e médias cidades; e preservar o meio rural, favorecendo empregos para jovens no local. Com isso, o governo stalinista conseguiu aplicar, dentre outros procedimentos, a regulação pública da terra, a indústria socialista da construção, a supremacia de investimentos públicos no setor imobiliário e o controle do estoque de moradia (BERNHARDT, 2005b). Uma fórmula que o governo soviético transpôs para países sob sua custódia na Europa Oriental - Polônia, Hungria, Bulgária, Alemanha etc. -, visionando explorar recursos naturais pela criação de inúmeras cidades.

Na Alemanha socialista (1949-1990), as CNs, embora empreendimentos privados, surgiram a partir de uma política pública soviética de consolidação industrial. Apresentavam, no geral, duas grandes particularidades: 1) base para construção de grandes indústrias, sendo "laboratório experimental para um sistema histórico de governo” (BERNHARDT, 2005a, p. 127, tradução nossa); e 2) estudo para a transformação de áreas agrícolas - onde uma classe burguesa ainda se fazia presente - em áreas industrializadas. Dentre as CNs

6 “[...] élaboration d'un schéma général de peuplement de U.R.S.S. qui est la véritable charte pour le développement et la création des agglomérations." 
alemãs, encontram-se quatro exemplares, todas empresariais e construídas por seus empresários: Stalinstadt (1951), atual Eisenhüttenstadt, erguida pela empresa Complexe Sidérurgique J.W. Stalin/Est; Hoyerswerda (1957), ligada ao complexo energético de Schwarze Pumpe; Schwedt (1959), ligada ao complexo petroquímico PCK - Petrochemisches Kombinat; e Halle-Neustadt (1964), construída para operários da indústria química, com previsão de atender a 70 mil habitantes - a maior de todas.

Na Itália (1922-1945), o movimento de urbanização territorial fascista começou pela aplicação de uma política antiurbana, traduzida pela prática da tabula rasa. O objetivo era venerar o novo regime e apagar todo traço da época precedente, construindo cidades conforme o ideal mussoliniano (VALLAT, 2001). Oficialmente, o objetivo dessa campanha antiurbana estava em racionalizar a utilização de uma mão de obra abundante dentro do território nacional, além de se transformar em um instrumento de propaganda do governo do Duce.

Os governantes fascistas trabalharam para disponibilizar uma bonificação agrícola capaz de animar regiões até então pouco habitadas e de promover uma industrialização economicamente eficaz. Para isso, necessitou apoiar-se sobre o planejamento do território, ou seja, visionar um desenvolvimento equilibrado do país. Para Donata Pizzi (2004), surgiram apenas 37 novos assentamentos; para Giorgio Pellegrini (2006), foram 137 novos villagios e borgos (aldeias), implantados entre 1922 e 1943 em várias regiões da Itália, dentre os quais se destacam: Mussolinia (1924), Sabaudia (1933), Aprilia (1936), Guidonia (1937) e Fertilia (1939).

Na Espanha de Franco (1938-1973), os nuevos pueblos planejados no Instituto Nacional de Colonização foram implantados sobre territórios até então inóspitos - zonas secas, alagadiças e subdesenvolvidas. A política de ocupação do governo franquista, financiada pelo Banco Central espanhol, iniciou por preparar os terrenos - programas de irrigação e drenagem, redes de serviço e sistema de estradas -, passando ao planejamento dos novos centros urbanos - desenhos inspirados nas 
cidades da América espanhola: quadrícula com a plaza central - e fechando com a instalação de infraestruturas necessárias ao desenvolvimento dessa nova rede urbana.

Contrapondo-se aos governos ditatoriais, a gestão democrática do presidente Franklin Delano Roosevelt (1882-1945), nos EUA, apresentou seu pacto de recuperação da crise econômica de 1929 no plano New Deal (1933-1937). Nele, encontramos especificamente o programa do Greenbelt towns, um sopro de planejamento nacional que incluiu a construção, entre 1935 e 1938, de três CNs: 1) Greenbelt (1935), localizada no estado de Maryland, entre Washington e Baltimore, criada para acolher funcionários públicos da capital americana; 2) Greenhills (1936), situada no estado de Ohio, próxima a Cincinnati; e 3) Greendale (1936), implantada no estado de Wisconsin, perto de Milwaukee - as duas últimas construídas para abrigar operários e minorias sociais (STEIN, 1989).

Numa escala menos ambiciosa que os programas europeus, as três greenbelt new towns foram concebidas como programas pilotos de economia cooperativa, conservação de terras e moradias a baixo custo (EDEN; ALANEN, 1983). Esse planejamento social e ambiental de CNs norte-americanas foi adotado, em parte, para atingir metas sociopolíticas, como acesso a moradias de qualidade - num total de 2,2 mil moradias construídas - e revitalização da economia regional. Todas eram controladas pelo poder público e dispunham de uma maior participação comunitária nas tomadas de decisões. O programa, porém, teve vida curta e as CNs foram tomadas por agentes privados a partir de 1954.

Após a Segunda Guerra Mundial, governantes ao redor do globo se beneficiaram das CNs como mecanismos de controle de crescimento das grandes cidades e como espaços destinados a resolver déficits habitacionais e empregatícios. New towns, villes nouvelles, cidades-satélites fervilharam pelas vizinhanças de metrópoles sob o comando atento do Estado.

Tendo o New Town Act (1946) da Inglaterra como ponto de partida mundialmente reconhecido, “baseado no suporte compreensivo do poder público” (WALKER, 1994, 
p. 7, tradução nossa), ${ }^{7}$ o movimento de cidades-satélites logo atravessou o Canal da Mancha e aportou no continente.

A política francesa de CNs nasceu da reflexão animada por Paul Delouvrier (1914-1995), inspetor de finanças, depois de pedido feito pelo presidente Charles de Gaulle no início dos anos 1960. Ao sobrevoar de helicóptero a região parisiense, de Gaulle pediu: “Delouvrier, mettez-moi de l'ordre dans ce bordel” (Paul Delouvrier, coloque-me ordem neste bordel), referindo-se ao caos no qual a periferia parisiense se encontrava (VADELORGE, 2005, p. 8).

O então primeiro-ministro Georges Pompidou (1911-1974), em diretrizes passadas a Paul Delouvrier em abril de 1966, exigiu a elaboração de um esquema diretor de planejamento da Grande Paris e de um esquema estrutural para as demais metrópoles francesas - Lion, Marselha, Lille etc. A solução encontrada foi a criação de CNs num esforço de humanizar, ordenar e controlar os movimentos de urbanização. A partir de cinco cidades-satélites na região parisiense e quatro próximas a cidades do interior Val-de-Reuil em Rouen; Lille-Est (ou Villeneuve d’Ascq) em Lille; Rives de l'Etang de Berre em Marselha; e L'Isle d'Abeau em Lion -, o programa sugeriu “um plano de conjunto, com articulação coerente entre diferentes bairros, tipos de arquitetura, diversidade de habitações, situadas ao redor de um centro atrativo e moderno [...], oferecendo a seus habitantes possibilidades de emprego, lazer e desenvolvimento cultural” (ROULLIER, 2004, p. 24, tradução nossa). ${ }^{8}$ Com isso, o governo francês pretendia:

[...] frear o desenvolvimento da mancha urbana de Paris, canalizando a urbanização em áreas definitivas, situadas na periferia e interligadas à capital por estradas tangenciais sem perpassar a região central; e evitar nestas áreas os fenômenos de periferização e da formação de cidades-dormitórios, pela criação de um verdadeiro

7 "[...] based on the comprehensive support of public power [...]"

8 "[...] un plan d'ensemble, assureront l'articulation cohérente de quartiers variés, de types d'architecture et d'habitation différentes autour d'un centre attractif et moderne [...] apporter à leurs habitants les possibilités d'emploi, de loisirs et de développement culturel." 
e próprio centro urbano, dotado de habitação, serviço e postos de trabalhos. (BERTUGLIA; TICH; STANGHELLINI, 2004, p. 12, tradução nossa). ${ }^{9}$

Portanto, o plano de CNs francesas foi o desejo estatal de planejar o território e a necessidade de melhor estruturar o desenvolvimento da aglomeração parisiense e das grandes metrópoles do interior (SUDOUR, 1987).

Da Inglaterra ou da França, onde tal política de urbanização tomou corpo, o uso de CNs como controle da expansão urbana sob comando estatal difundiu-se por outros países da Europa assim como para outros continentes.

Na Dinamarca, a vontade política de frear o crescimento de sua capital gerou o "Plano dos Dedos" (1963): da palma (Copenhague) sairiam cinco dedos linhas férreas - para a periferia e propostas cinco CNs, dentre elas, Albertslund (1963), a primeira a ser construída e projetada para 40 mil habitantes (HELAND, 2005). Política similar adotada pelo governo socialista sueco para sua capital, Estocolmo, cujos arredores foram tomados por inúmeras CNs, como Vällingby (1950) (BOUCHER-HEDENSTRÖM, 2005). Na Espanha pós-franquista, o ministro da Habitação, Vicent Mortes Alfonso, propôs o ACTUR (Actuations Urbanica Urgentes) nos anos 1970, que consistia em criar um amplo número de moradias, independentemente do processo de desenvolvimento, por meio de CNs erguidas no entorno de grandes cidades e livres de restrições locais de planejamento (CARRERAS, 1986). Nos arredores de Barcelona, três CNs da ACTUR foram propostas num raio de 15 a 20 quilômetros, sobre terras virgens, com previsão de 150 mil pessoas cada.

9 “[...] per frenare lo sviluppo dello spot urbano di Parigi, canalizzando l'urbanizzazione in aree definitive, situate nella periferia e interconnesse alla capitale attraverso strade tangenziali senza attraversare la regione centrale; ed evitare in queste aree i fenomeni di perifericizzazione e formazione di dormitori cittadini, con la creazione di un vero e proprio centro urbano, dotato di alloggi, servizi e postazioni di lavoro." 
Na Ásia, o empreendedorismo estatal para criar CNs esteve presente no Japão, na Coreia do Sul, em Hong Kong, em Cingapura, na Tailândia, na Índia, no Irã, sem mencionar dezenas e dezenas de exemplares empreendidos pelo governo chinês no século XXI.

Na terra do sol nascente, a participação de órgãos ligados ao governo, envolvidos com questões relacionadas à habitação e ao desenvolvimento urbano, é um dos exemplos mais nítidos do desejo público em efetivar CNs. Exemplo disso é a cidade-satélite de Tama (1965), concebida pela Corporação de Desenvolvimento Habitacional e Urbano e implantada nos arredores de Tóquio (DUCON; YOKOHARI, 2006). Na vizinha Coreia do Sul, o governo lançou, em fins dos anos 1980, um plano para a construção de 2 milhões de habitações, efetivado a partir da construção de cinco CNs nas cercanias de Seul: Bundang, Ilsan, Pyeongchon, Sanbon e Joongdong (LEE; AHN, 2005).

No sudeste asiático, as propostas surgidas foram similares. Em Hong Kong, o programa de CNs previa oferecer 1,8 milhões de moradias em nove CNs (HUI; LAM, 2005); em Cingapura, as CNs de Bukit Batok e Bishan foram resultados de programas públicos de habitação para massas (ENG, 1996); e, na Tailândia, as políticas de desconcentração industrial de Bancoc e de habitação, durante os anos 1970, promoveram o surgimento de CNs, como Bang Plee (1978), cuja preocupação era buscar um equilíbrio entre moradia e emprego, condição primordial de autonomia de uma cidade nova (BARON, 1992).

Na Índia, o governo, dentre as inúmeras políticas de desenvolvimento, preocupou-se em afastar as novas indústrias de grandes e congestionadas cidades, ao considerar: o conceito de região; o planejamento de áreas urbana e rural de modo associado; e a ocupação do campo com uma diversidade de produção para garantir a independência da região (PRAKASH, 1969). Desde a Independência, em 1947, mais de 30 CNs foram construídas na Índia. Primeiro com as cidades administrativas - Nova Délhi e Chandigarh - ou com cidades para abrigar refugiados vindos do Paquistão. Em 1951, com o plano quinquenal, novas cidades surgiram em áreas de projetos de irrigação, drenagem e de energia. Posteriormente, a ênfase passou para 
CNs industriais como apoio a usinas. Com isso, as CNs indianas foram utilizadas pelo Estado como modo planejado de dispersão da população centralizada nas grandes cidades e como instrumento de desenvolvimento econômico.

Assim, percebemos um tipo de urbanismo adotado por diferentes culturas, em realidades diversas. Um tipo urbanístico que não encontrou barreiras nem preconceitos, sendo adotado tanto por países liberais do ocidente como por países islâmicos do oriente, cito Irã e Argélia, onde as CNs foram utilizadas como estratégia política para descongestionar as grandes cidades.

No país norte-africano, a política de CNs surgiu como resposta a um duplo problema: acolher a população da capital Argel, como fez a CN de Badjarah-Ouchaya (1958), e dinamizar regiões pobres. Já as CNs de Roche Noir - atual Boumerdès - e de Aïn Oussera surgiram no início da década de 1960 como cidades administrativas, pretexto de novos governantes para marcar simbolicamente sua independência da França em 1975 (JOSSIFORT, 2000). Ainda nos anos 1970, o COMEDOR - Comitê Permanente de Estudos de Desenvolvimento, de Organização e de Planejamento da Aglomeração de Argel - previu a criação de polos urbanos dinâmicos, organizados em arcos - quatro coroas - ao redor da capital argelina. As CNs foram organizadas em dois grupos: o primeiro deveria descongestionar as metrópoles litorâneas pela implantação de polos urbanos nas $1^{\mathrm{a}}$ e $2^{\mathrm{a}}$ coroas - CNs com funções para turismo ou centros de pesquisa e tecnologia; o segundo teria por objetivo acompanhar a valorização de regiões do alto platô e do sul argelino, como a CN de Boughzoul.

Por fim, além das políticas de ocupação territorial e controle da urbanização existente, os governos de países em desenvolvimento assumiram a criação de CNs visando à exploração de recursos minerais, verificável no Brasil dos anos 1950 a 1980 - como veremos no início dos capítulos 2 e 6 - e em países da África.

Contemporânea a Beida (1965), na Líbia, visionada para ser o maior centro administrativo do país, e a Kafue (1966), na Zâmbia, cuja função era atrair população da capital Lusaka e criar um novo polo industrial - ambas projetadas pelo escritório grego Doxiadis Associates (DOXIADIS ASSOCIATES 
INTERNATIONAL, 1971) -, temos a CN de Malbaza (1967), na Nigéria. Nesse caso particular, o objetivo do governo nigeriano era possuir, em seu território, uma usina de cimento para fomentar a industrialização do país, criar novos empregos e diminuir as importações.

Setor privado e suas cidades novas

Com atuação em conjunto com órgãos estatais ou por iniciativa isolada, as ações do setor privado em prol do surgimento de CNs vão ser recorrentes, particularmente após a Revolução Industrial, graças à presença de capital excedente nas mãos de indivíduos e de sociedades empresariais.

Antes do aparecimento das indústrias, a Europa já apresentava exemplares de CNs privadas. Segundo Olivier Zeller (2003), na Polônia e na Ucrânia dos séculos XVI e XVII, CNs foram fundadas por iniciativa de famílias nobres como apoio à comercialização de produtos agrícolas - por exemplo, a CN polonesa de Ulanow, de 1616. Essas pequenas cidades (agrovilas) tinham uma escala menor que as cidades reais, com apenas um elemento que as caracterizava como urbana: a presença do mercado, devendo seus moradores respeitar as regras estabelecidas pelo dono da cidade. Algo semelhante ocorreu na Irlanda do século XVIII com as landlord towns, frutos de uma política de remodelação da geografia daquele país bem como do intuito de promover fundações de cidades com espaços culturais que reforçassem a dominação anglicana.

No berço da indústria moderna, Inglaterra, as CNs privadas assumiram a figura de company towns e datam da segunda metade do século XVIII (SICA, 1981 e CREESE, 1992). Porém, foi a partir de meados do século XIX que surgiram significativos projetos de cidades ou vilas empresariais: um tipo cuja origem estava relacionada à criação de indústrias em áreas não assentadas, que dispunham de recursos naturais - bens primários, energia natural gerada por água, minas de carvão etc. - para a produção, melhoria das condições de vida e disciplinamento da mão 
de obra industrial. Entre os assentamentos ingleses financiados por capital privado estão: Copley (1847), Saltaire (1851), Akroydon (1859), Bournville (1879) e Port Sunlight (1888).

Quase que simultaneamente às company towns, surgiram as cidades recreativas - empreendimentos lucrativos para inúmeras sociedades e grupos financeiros que se apoderavam de áreas ambientalmente interessantes - praias, montanhas, reservas de aquíferos termais - em busca de lucro pela renda imobiliária. Em muitos casos, essas indústrias sem chaminés tornavam-se renda de monopólio uma vez que a oferta era quase irreprodutível. Os empreendedores também foram beneficiados pela ajuda de Estados, que incentivavam a exploração e o desenvolvimento desse setor da economia.

Na Inglaterra, aglomerações surgiram com finalidade recreativa: as estâncias termais de Buxton (1780) e Cheltenhan (1800); as litorâneas Brighton (1820, de iniciativa privada da empresa Cliff Bridge Company), e Bournemouth (1835).

Esse grupo de cidades inglesas, projetadas e planejadas para atender a uma determinada função - lazer e saúde - por meio de elementos urbanísticos ou da presença de edifícios especializados - balneário, hotéis, cassino -, criou raízes não apenas em território britânico como saltou ao continente europeu e americano, ${ }^{10}$ atraindo interesses de investidores privados.

Além desses tipos de investimentos, o setor privado, no século XX, direcionou sua atenção para a exploração de recursos minerais, visando à fomentação da indústria primária. No continente africano - cujo subsolo é rico em recursos naturais (petróleo, urânio, ferro, ouro, diamante, fosfato) -, a criação de CNs esteve diretamente relacionada ao desejo de certos financistas engajados na exploração dessas riquezas. Para A. Moussa (1972), as CNs africanas surgiram como um disfarce luxuoso para a forma de exploração que ainda continua desde o período

\footnotetext{
${ }^{10}$ Outros exemplos de cidades balneárias: Alemanha (Baden-Baden e Marienbad); Áustria (Josefplatz, Badgastein e Bad Ischl); Bélgica (Ostende e Spa); Espanha (San Sebastián); França (Deauville, Canche e Vichy); Holanda (Scheveningen); Suíça (Carlsbad, Davos, Grindelwald, Zermatt e St. Moritz); Estados Unidos da América (Saratoga Springs, Lenox, Colorado Springs, Newport e Miami); e Brasil (Guarujá, Campos do Jordão, Águas da Prata, Águas de São Pedro, Araxá etc.).
} 
da colonização. Seus empreendedores eram sociedades mineradoras e industriais estrangeiras, cuja “preocupação maior não é [era] de ser ‘bons apóstolos’ para a população, mas de explorar um grande benefício a custo baixo” (MOUSSA, 1972, p. 6, tradução nossa). ${ }^{11}$ Dentre as CNs africanas de iniciativa privada, temos: Tema (1952), em Gana, empreendida pela Tema Development Corporation; e Gamba (1969), no Gabão, patrocinada pelo grupo petroquímico da Shell. Hoje, a presença de capital chinês em países detentores de reservas petrolíferas é reconhecida, contribuindo para o aumento de CNs naquele continente.

Particular vai ser o caso norte-americano. Após a independência em 1776, houve uma reação, liderada por promotores privados e especuladores, contra o planejamento realizado por autoridades governamentais sobre a localização das cidades. O objetivo era deixar o número e a distribuição dos núcleos urbanos à mercê da força do mercado, garantindo, assim, a obtenção de benefícios e lucros num sistema de livre concorrência (HAMER, 1994). Desse modo, enquanto os empreendedores procuravam terrenos livres, sobretudo aqueles presentes em eixos de crescimento, longe das aglomerações existentes, o Estado apenas participava das questões financeiras e de implementação de infraestruturas.

Os exemplos de CNs norte-americanas como empreendimentos privados percorrem desde o planejamento Mórmon de cerca de 350 cidades no oeste do país entre 1847 e 1877, como Salt Lake City (1847), passando por cidades empresariais fechadas, como Pullman (1880) e Hershey (1897) (BLOOM, 2005), até CNs empresariais da segunda metade do século XX, como: Mission Viejo (1963), ligada à empresa Philip Morris; Woodlands (1969), empreendida pela Woodland Development Corporation, uma filial da Mitchell Energy and Development Corporation (LOEVENBRUCK, 1986).

Já na Austrália, entre 1770 e 1830, a maioria das iniciativas de fundar e planejar cidades cabia ao Estado, particularmente ao governo inglês. A partir daí, esse

11 “[...] la préoccupation n'est pas d'être de « bons apôtres » pour la population, mais d'exploiter un grand avantage à faible coût.” 
papel foi dividido com agentes privados, incluindo companhias colonizadoras (HAMER, 1994), principalmente na promoção de cidades secundárias para empresas privadas. Como exemplos, South Australia (1835), fundada por uma companhia fortemente influenciada pelas teorias colonizadoras de Edward Gibbon Wakefield, ${ }^{12}$ e Melbourne (1838), uma das primeiras cidades modernas a se utilizar do cinturão verde como controle de expansão territorial e locação de equipamentos urbanos.

Atualmente, na Inglaterra, casos envolvendo capital privado e construção de cidades ainda acontecem. O surgimento de novos assentamentos no sudeste britânico e na região de East Anglia são ações de grupos de construtores habitacionais e outros agentes desenvolvimentistas privados. Já para o entorno de Londres, foram propostas de três a quatro CNs com 75 mil a 100 mil habitantes. Trata-se de "uma resposta inevitável ao processo de descentralização das grandes cidades para pequenos assentamentos ou áreas rurais; ou um novo modo de pensar a mudança de áreas dinâmicas economicamente no Reino Unido” (HERINGTON, 1988, p. 308, tradução nossa). ${ }^{13}$

Seja por empreendedores do setor privado ou do poder público, enfim, o panorama apresentado nos coloca em contato direto com o primeiro atributo caracterizador de CNs na metáfora aqui empregada, isto é, o primeiro segmento do seu DNA. O desejo em criar cidades nos revela a importância do agente desejador bem como os frutos deixados por tal ação - CNs surgidas nos quatro cantos do planeta a fim de suprir uma vontade e, necessariamente, uma função, como posto a seguir.

12 O político inglês Edward Gibbon Wakefield (1796-1862) foi responsável por criar um planejamento de colonização da Austrália, que atraía imigrantes do Reino Unido pela oferta de trabalhos e terras. Para ele, seria uma válvula de escape para os problemas sociais e para o rápido e descontrolado crescimento das grandes cidades inglesas.

13 "[...] an inevitable answer to the decentralization process of large cities to small settlements or rural areas; or a new way of thinking about changing economically dynamic areas in the UK." 


\section{Cidades novas e a necessidade}

Segunda parada: Serra do Navio, Amapá.

Sob o solo brasileiro, reservas e mais reservas minerais repousam à espera de serem subtraídas, processadas e comercializadas. Reservas como a de manganês na Serra do Navio, no estado do Amapá. Em plena selva amazônica, a descoberta, na década de 1940, desse importante minério - indispensável à indústria do aço despertou o interesse do governo e de empresas privadas.

Declarada reserva nacional por decreto-lei de 1946, sua exploração deveria ficar sob a responsabilidade de uma empresa brasileira. Após concorrência pública aberta em 1947, a pequena ICOMI S.A. - Indústria e Comércio de Minérios -, presidida pelo engenheiro Augusto Trajano de Azevedo Antunes, recebeu autorização para pesquisar as jazidas (MONTEIRO, 2003).

Tal sondagem e divulgação do volume de minério encontrado fez valorizar o capital da empresa, ${ }^{1}$ que, em 1950, se associou à gigante norte-americana Bethlehem Steel Company (indústria metalúrgica). Esta, além do aporte financeiro, introduziu a tecnologia indispensável para a extração, como apontou o relatório da ICOMI de 1960:

[...] na ocasião, não existindo no país nem a técnica especializada nem os recursos financeiros que permitissem realizar obra de mérito, à altura dos interesses da Nação, a ICOMI buscou entendimentos no exterior, tendo conseguido interessar a Bethlehem Steel Company, empresa americana, que reunia todas as credenciais

1 À época, o maior produtor de manganês no mundo era a União Soviética, que, em plena Guerra Fria, suspendeu sua exportação e deixou seu maior rival, os Estados Unidos da América, sem a principal matéria-prima para a produção de aço. 
para tornar o empreendimento um sucesso completo. (apud MONTEIRO, 2003, p. 118).

Fosse por jogada política de um governo liberal, fosse um processo natural do mercado, é fato que a presença das minas de manganês na Serra do Navio demandava uma reestruturação ambiental para dar suporte às atividades minero-metalúrgicas, cuja concessão para exploração foi fornecida em 1953 por um período de 50 anos.

Distante cerca de 200 quilômetros da capital Macapá, a primeira necessidade foi ligar a área, localizada no centro do então Território Federal do Amapá, até o rio Amazonas: um corredor que levasse a produção diretamente das jazidas ao porto. Assim, uma linha férrea de 193 quilômetros foi implantada pela ICOMI bem como um bairro portuário no município de Porto Santana, a Vila Amazonas - inicialmente Vila de Macapá. Mas havia ainda a carência de um núcleo urbano de apoio na zona de extração e preparação do minério. Foi assim que surgiu, nos anos 1950, a CN Serra do Navio.

Tanto o projeto da vila portuária quanto o da CN empresarial no meio da floresta ficariam a cargo de um escritório de arquitetura selecionado após convites realizados pela própria ICOMI. A escolha recaiu sobre o ateliê, sediado na capital paulista, do arquiteto-engenheiro Oswaldo Arthur Bratke (1907-1997), pela postura extremamente pragmática dada aos seus projetos (SEGAWA; DOURADO, 1997). O contrato vigorou de 24 de outubro de 1955 a 8 de janeiro de 1960 - data de entrega da obra finalizada.

A “arte de bem projetar e bem construir”, como enfatizam os autores Hugo Segawa e Guilherme Dourado no livro Oswaldo Arthur Bratke, de 1997, refletiu-se nas casas modernistas e nos edifícios públicos que o profissional brilhantemente formalizou em centenas de aquarelas pinceladas desde sua formação, em 1931, na Escola de Engenharia da Universidade Mackenzie (SP). Um arquiteto preocupado não apenas em transformar a cultura e os conceitos de sua época em obras arquitetônicas, mas persuadido em realizar um espaço com qualidade ambiental, de traços elegantes, estruturas delgadas, aberturas milimetricamente posicionadas, 
proporcionando jogos de luz e sombra, materiais ricamente explorados, além do uso indiscriminado de recursos tecnológicos - brises, caxilhos, cobogós etc. - a favor do bem-estar do usuário.

Predicados que o arquiteto, natural de Botucatu (São Paulo), não omitiu nos projetos urbanísticos para a Vila Amazonas e para a CN empresarial Serra do Navio. Em contrato assinado, Bratke foi incumbido pela empresa ICOMI de: planejar o urbanismo de ambos os núcleos com a devida infraestrutura (vias, redes de água, esgoto, águas pluviais, energia etc.); projetar casas conforme a hierarquia funcional (de operários a trabalhadores de alto escalão); projetar edifícios públicos (hospitais, escolas, clubes e demais prédios de interesse coletivo) - tudo devidamente desenhado em plantas, cortes e fachadas e orçado a cada etapa de execução. O programa previsto deveria garantir para Serra do Navio completa independência e autossuficiência (SEGAWA; DOURADO, 1997).

O empenho do arquiteto paulista pode ser verificado pelas frequentes idas ao Amapá a fim de obter conhecimento sobre sua realidade, vivenciando aspectos sociais e monitorando, de perto, o despertar de uma nova cidade. Além disso, viajou também à Venezuela - país com as mesmas condições climático-ambientais -, visando a enriquecer seu repertório. Lá, Bratke visitou cidades empresariais, uma delas a El Pau, projetada pela empresa Bethlehem Steel Company. Porém, os estudos de casos analisados só serviram como contrarresposta, algo que deveria ser evitado no projeto brasileiro. Segundo o arquiteto (apud SEGAWA; DOURADO, 1997), essas cidades eram estruturalmente mal organizadas, com moradias de baixa qualidade para os operários, sendo fonte de interesse apenas pelas informações repassadas por seus habitantes, como o ritmo de vida e as necessidades dos moradores de uma vila empresarial.

Assim, a proposta para Serra do Navio nasceu, contendo uma preocupação ambiental e disposta a oferecer condições mínimas a todos os seus moradores, sem distinção. De início, Bratke estipulou o tamanho real da cidade, com auxílio de funcionários da própria empresa, chegando a uma previsão de 1.729 habitantes para a fase inicial e 2.544 para a fase final - número ampliado, posteriormente, para 
3.500 pessoas (SEGAWA; DOURADO, 1997). Tais dados e prognósticos foram articulados em tabelas, em que o autor planejou, justificou e dimensionou todos os componentes urbanos necessários à $\mathrm{CN}$.

Enquanto todo o projeto era detalhado no ateliê em São Paulo, Bratke, no Amapá, selecionava as tecnologias e os materiais a serem empregados. Cimento, telhas de fibrocimento e 20 tipos de madeiras locais foram meticulosamente articulados na confecção dos edifícios pelo arquiteto modernista, sob a orientação do engenheiro Luiz de Mello Matos, amigo de Augusto Trajano Antunes (ICOMI) e parceiro de Bratke em obra paulista. Os materiais industrializados eram trazidos após longa jornada de estados do sul do país ou de Miami (EUA). As obras eram racionalmente projetadas para garantir uma construção rápida e sem desperdícios. Vidros, por exemplo, foram minimamente utilizados somente em clubes e algumas casas - devido ao clima local e ao custo elevado, sendo substituídos por outras soluções mais apropriadas - telas, mosquiteiros e painéis em madeira com aberturas pivotantes. A funcionalidade e o acabamento das obras arquitetônicas foram condizentes com o plano urbanístico proposto para o novo assentamento.

Localizado a 1,2 quilômetro da área de mineração e distante do rio, devido à neblina matutina, o plano urbano herdou o viés modernista de Bratke. Ao adequar o traçado à geomorfologia do terreno, o arquiteto setorizou as funções urbanas em meio à clareira aberta na floresta (REVISTA AU, 1987). Depois de inúmeros estudos, a CN foi organizada em dois polos interligados por um eixo principal em torno do qual foram dispostos os principais equipamentos urbanos: hotel, centro esportivo, clube, hospital, centro cívico e escola. Cada polo recebeu vias locais e tipos de habitações diferenciadas, sendo um conjunto para operários (o mais adensado, dividido em moradias para famílias e alojamentos para solteiros) e outro para funcionários formados (dividido em moradias para funcionários de nível médio e para graduados). Todo o assentamento foi implantado com uma lacuna de 25 metros de distância da floresta - evitando-se transtornos com a queda de árvo- 
res - e ambientado por uma "flora exótica”, elaborada por um jardineiro alemão indicado pelo professor de Botânica da USP, Aylthon Joly Brandão (SEGAWA; DOURADO, 1997, p. 267).

Aqui, portanto, mais um exemplar da urbanística brasileira merecedor de nossa atenção pela habilidade com que seu plano foi conduzido pelas mãos do arquiteto-engenheiro Oswaldo Arthur Bratke. Interessa-nos, contudo, sua inclusão nesta pesquisa por uma característica em particular: a necessidade de sua criação como apoio às atividades previstas por seus empreendedores.

Figura 8: Serra do Navio

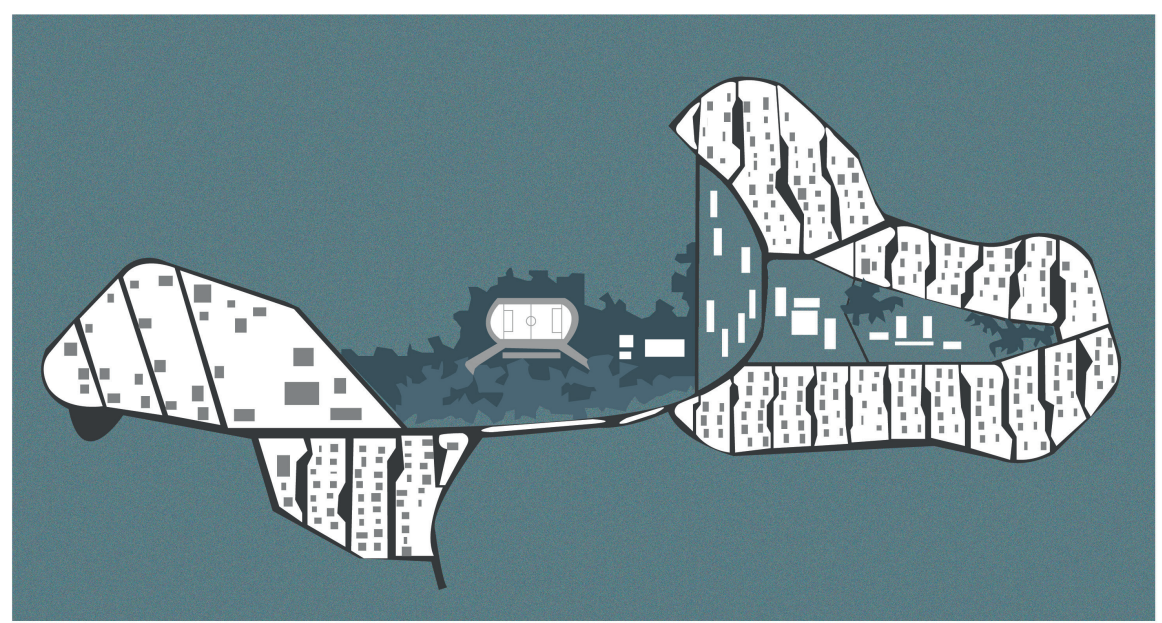

A exploração do minério de manganês em região inóspita seria, evidentemente, inviável sem a presença da CN. A oferta de trabalho e a demanda por mão de obra qualificada para tal produção dependiam diretamente da construção de espaços estáveis. Urgia, portanto, um ambiente artificialmente planejado e rapidamente executado para atender às exigências de seus investidores e de seus moradores. Nesse sentido, a CN surgiu como uma necessidade, com a função principal de acolher trabalhadores e dar suporte às atividades extrativistas. 
O caso de Serra do Navio não foi o primeiro e nem o último de nossa história. As CNs empresariais de Fordlândia (1920) no Pará, Monlevade (1934) em Minas Gerais, e Votorantim (1940) em São Paulo atestam tal antecedência. Assim como políticas desenvolvimentistas adotadas, principalmente durante o regime militar (1964-1985), vão sequenciar o nascimento de outras CNs similares.

Em 1972, por exemplo, o governo do presidente general Emílio Garrastazu Médici (1905-1985) lançou o I Plano Nacional de Desenvolvimento (1972-1974), cuja responsabilidade de implementação foi dada ao Serviço Federal de Habitação e Urbanismo (Serfhau). ${ }^{2}$ Os objetivos do I PND incluíam: propor um crescimento econômico para o país mediante um processo de competição conjunto com um processo de integração de áreas defasadas; compatibilizar os planos setoriais territorialmente, visando à formação rápida de uma estrutura nacional eficiente e adequada de produção, distribuição e consumo de bens e serviços; e colocar o país como potência mundial (BRASIL, 1972).

Para elevar o Brasil a uma categoria de país desenvolvido, destacam-se aqui as seguintes atividades previstas (BRASIL, 1972):

1. implantação de novos instrumentos para modernizar a empresa nacional;

2. atuação eficiente do governo;

3. mobilização mais intensa do sistema financeiro nacional e do mercado de capitais;

4. implementação da Política Tecnológica Nacional;

5. efetivação de certo número de grandes programas de investimentos, como os programas de expansão da Siderurgia e Petroquímica;

2 O Serviço Federal de Habitação e Urbanismo (Serfhau) foi o órgão nacional de desenvolvimento urbano responsável pelos projetos e planos na primeira fase de planejamento do regime militar (1964-1974). Ligado ao Ministério do Interior (Minter), foi criado juntamente com o Banco Nacional da Habitação (BNH) pela Lei n. 4.380, de 21 de agosto de 1964, posteriormente regulamentada pelo Decreto n. 59.917, de 30 de dezembro de 1966. 
6. política de aproveitamento dos recursos humanos do país como fator de produção e de consumo; e

7. realização de estratégia regional para efetivar a integração nacional.

Esse é um panorama que nos permite compreender as conjunturas do surgimento de CNs empresariais, principalmente ligadas a um ambicioso programa de pesquisa e aproveitamento de recursos minerais.

Mediante sondagens realizadas por órgãos ligados ao governo (como as Superintendências de Desenvolvimento - Sudam, Sudene e Sudeco - e o Instituto Nacional de Colonização e Reforma Agrária - Incra), reservas de bauxita, cobre, manganês etc. foram identificadas e repassadas por concessões temporárias a empresas estatais, responsáveis por explorá-las e exportar seus produtos. Desse modo, polos siderúrgicos surgiram em diferentes unidades federativas, dando origem a CNs, como Carajás (1973) no Pará, Camaçari (1977)³ e Caraíba (1978) na Bahia, e Primavera (1979) em São Paulo. CNs cujo DNA apresenta os seis segmentos apontados: o envolvimento de empreendedores (governo), um sítio estratégico (acima de jazidas minerais), a participação de profissionais (arquitetos e engenheiros) em seus projetos, um tempo preciso de construção e fundação e, principalmente, a necessidade de existirem. O segundo segmento de estruturação do DNA das CNs, a necessidade, possibilita-nos responder por que tais assentamentos foram criados, assim como identificar a função dominante presente ao menos em sua fase inicial.

\subsection{Funções e exemplares}

Toda cidade, espontânea ou criada, tem por função conceitual "transformar o poder em forma, a energia em cultura, a matéria morta em símbolo vivo de arte, a

3 A CN de Camaçari, a 46 quilômetros de Salvador, nasceu em 1977, quando o plano urbanístico, confiado à prefeitura do município, foi iniciado. Até essa data, não passava de uma pequena cidade de menos de 20 mil habitantes, sendo escolhida para receber o segundo complexo petroquímico do país (D’ARC; SCHNEIER, 1983). 
reprodução biológica em criatividade social” (MUMFORD, 1992, p. 30, tradução nossa). ${ }^{4}$ No cotidiano da vida urbana, toda cidade deve apresentar funções práticas, aquelas relacionadas às necessidades de seus habitantes.

O sobressalto de uma dessas funções frente às demais pode servir para caracterizar uma cidade, como fez o historiador Pierre Deffontaines ao qualificar os núcleos do período colonial brasileiro. Segundo o autor, as antigas aldeias, vilas e cidades podiam ser classificadas pelas atividades principais que abrigavam: "reduções missionárias”; “aglomerações de origem militar”; “cidades mineiras”; "pousos nas estradas” (cidade de viajantes); “cidades de navegação fluvial ou marítima”; "vilas de domingo”; e “aldeias indígenas” - uma distinção social (apud FRIDMAN, 2005, p. 46-48).

Não exclusivo a historiadores, tal método taxonômico transitou por outras disciplinas, como na geografia, onde encontramos as cidades do café, da borracha, da indústria, das colônias de imigrantes, de comércio, balneárias e turísticas (SOUZA, 2001). No Direito Urbanístico, em rastreamento realizado por Nuñez Ruiz, outra possibilidade nos é repassada pela cidade:

[...] militar (cidade-quartel, bases e centros de instrução, aeroporto

e base naval militar); política (cidade-internacional, cidade-nação, cidade regional ou capital); religiosa (cidade de peregrinação, cidade de festas religiosas); intelectual (cidade universitária, cidade estudantil, cidade patrimônio, cidade cultural); econômica (cidade boca ou sertão, cidade ponte de trilhos, cidade agrícola, cidade comercial, cidade financeira, cidade industrial, cidade centro de serviços); turística e/ou residencial (cidade dormitório); médico-sanitária (balneárias etc.); recreativa (beira-mar, montanha). (apud BRASIL, 1973, s.p.).

4 “[...] trasformare il potere in forma, l'energia in cultura, la materia morta in simbolo vivente dell'arte, la riproduzione biologica nella creatività sociale." 
Essa amostra de enquadramentos funcionais cabe tanto às cidades tradicionais como às CNs, com uma singela diferença: enquanto, numa cidade tradicional, tal qualificação é feita após seu desenvolvimento, quando já adquiriu sua identidade, numa CN a função prevalecente é determinada no momento de sua concepção, com o auxílio de seu empreendedor, mesmo antes de sua materialização. Não importa se, ao longo de sua história, outras funções venham a se sobrepor à sua função original - a CN sempre terá, em sua certidão de nascimento, a causa para qual foi gerada.

Nesse sentido, da facilidade em identificar a função para qual uma cidade foi criada, muitos autores tiram partido para classificar as CNs. ${ }^{5}$ Tal apropriação é endossada por uma rápida análise urbana, na qual alguns elementos particulares da paisagem podem revelar sua função de berço, seja pela presença da igreja na praça matriz, de um centro cívico, de um forte, de uma ferrovia, de uma rodovia, de uma hidrelétrica, de uma rede hoteleira, de uma empresa mineradora etc.

Assim, em grande parte dos estudos analisados, ${ }^{6}$ a taxonomia desse tipo urbanístico é realizada pela função para a qual tal núcleo foi empreendido: CN administrativa, $\mathrm{CN}$ de colonização, $\mathrm{CN}$ ferroviária, $\mathrm{CN}$ de realocação, $\mathrm{CN}$ balneária, CN satélite, CN de expansão, entre outras.

Para R. C. Gupta (1983), as CNs foram construídas para propósitos especiais, seja sediar: um porto (CN de Tema em Gana, CN de Kompong Som no Camboja, e CNs de Kandala e Maldia na Índia), uma indústria (as steel cities na Índia), uma capital (Chandigarh, Islamabad, Brasília), uma nova zona agrícola (CNs da região do Mandi, em Punjabi), uma expansão urbana (new towns inglesas ou

5 Embora não identificado na literatura analisada, reconheço que outras possibilidades de classificação seriam cabíveis, como separar CNs pela filiação projetual adotada, pelo período no qual foi implantado, pelo tipo de sítio escolhido, pelos profissionais envolvidos etc.

${ }^{6}$ Referenciam-se aqui, por exemplo, os trabalhos: Les villes nouvelles, de Pierre Merlin (1969a); La création des villes nouvelles, de Vito Ahtik (1969); El proceso de urbanización en America Latina y Venezuela, de Samuel Benchimol (1973); New-town planning, de Gideon Golany (1976); New towns, de Frederic Osborn e Arnold Whittick (1977); Cidade brasileira, de Murillo Marx (1980); Arquitetura contemporânea no Brasil, de Yves Bruand (1981); New towns around the world, de Stephen Potter (1987); Les villes dans le monde, de Pierre Bloc-Duraffour (1998); e A cidade como história, de Eloísa Pinheiro e Marco Aurélio Gomes (2005). 
CN Diego de Losada, na Venezuela). Sequenciando, Farhad Atash (2000, p. 68, tradução nossa) ${ }^{7}$ acrescenta:

Cidade nova como instrumento de abertura de novas regiões a serem exploradas, como a Ciudad Guayana (Venezuela); cidade nova utilizada para promover desenvolvimento em áreas remotas, menos desenvolvidas, pela concentração populacional, e de atividades econômicas em áreas que possuíam grande potencial.

Já um estudo iraniano (IRAN, 1991) limitou as CNs a apenas três tipos:

1. Cidades residenciais (cidades-dormitórios), como as cidades novas criadas ao redor do Cairo, Caracas, Hong-Kong, Shangai, Paris e Londres;

2. Cidades-satélites, como Tema em Gana, San Pedro na Costa do Marfim e Fulad Shahr no Irã; e

3. Novas cidades no estrito senso da palavra, como as cidades administrativas e centros políticos de Chandigarh (Índia), Brasília (Brasil), Abuja (Nigéria), Duduma (Tanzânia).

Focando nossas atenções no contexto nacional, em minha trajetória de pesquisa, cheguei às seguintes possibilidades: 1) CN empresarial (Barcarena, no Pará, Alumínio, em São Paulo, ou Siderópolis, em Santa Catarina); 2) CN ferroviária ou "boca de sertão” (Erechim, no Rio Grande do Sul, Franca e Jales, em São Paulo); 3) CN rodoviária (Marabá, no Pará, e Ceres, em Goiás); 4) CN de penetração (Aragarças, em Goiás); 5) CN de realocação (Remanso, na Bahia, Canindé do São Francisco, em Sergipe, ou Aripuanã, em Mato Grosso); 6) CN administrativa (Oeiras, no Piauí, Aracajú, em Sergipe, e Palmas, no Tocantins);

7 "New town as an instrument for opening new regions to be explored, such as Ciudad Guayana (Venezuela); a new town used to promote development in remote, less developed areas, by population concentration and economic activities in areas that possessed great potential." 
7) CN balneária ou recreativa (Lambari, em Minas Gerais, ou Águas de Lindóia, em São Paulo); 8) CN de colonização ou fronteiriça (Panorama, em São Paulo, Ângulo, no Paraná, ou Nova Veneza, em Goiás); 9) CN religiosa (missões do Rio Grande do Sul); 10) CN de defesa (São Luís, no Maranhão, e Nossa Senhora da Conceição, em Rondônia); 11) CN satélite (Taguatinga, Guará I e Guará II, no Distrito Federal); e 12) CN de expansão (Santos, em São Paulo, e Boa Vista, em Roraima). Uma lista efêmera, aberta a acréscimos e sugestões!

No conjunto, podemos verificar aspectos comuns em todas as classificações. As funções das CNs são determinadas em sua origem por seus empreendedores, visando a atender necessidades de cunho político, econômico, social e/ou cultural. Isso se torna claro nas produções realizadas em diversos países.

Se, na Antiguidade, no Medievo e na Modernidade, a recorrência a CNs se dava pela preocupação em defender fronteiras (acampamentos romanos) e ocupar territórios (cidades da América espanhola e portuguesa), no mundo contemporâneo ela será aplicada conforme as necessidades de nossa Era. Uma diversidade de funções que percorrem desde as emblemáticas CNs capitais, se popularizam com as CNs satélites (new towns, villes nouvelles etc.), repousam sobre balneários luxuosos no litoral, no campo ou nas montanhas, prosseguem com sua luta por ocupar e colonizar territórios pouco explorados e personificam a alma econômica pós-Revolução Industrial mediante CNs empresariais.

Mais emblemáticas e simbólicas do que numerosas, as CNs administrativas apresentam uma função que justifica sua existência: concentrar as estâncias governamentais do poder público. Por razões estratégicas de uma política frequentemente associada às necessidades econômicas e de planejamento territorial, numerosos governos adotaram as CNs administrativas como saída. Uma solução que Pierre Merlin (1977) também interpretou como uma tentativa de romper a dominação de uma ou mais grandes cidades situadas numa região muito desenvolvida (Sidney e Melbourne, na Austrália; e Rio de Janeiro e São Paulo, no Brasil), ou uma vontade de ocupar todo um espaço nacional, centralizando a posição de 
sua capital (Brasília e Ankara), ou ainda uma devolução de uma capital a um Estado repartido (Chandigarh).

Sejam quais forem os propósitos originais, governos dos EUA, Austrália, Turquia, Índia, Brasil, Nigéria, Cazaquistão etc., além de comandos regionais, decidiram por transferir todo o aparato administrativo de capitais anciãs para um espaço urbano inédito, especificamente projetado para atender às exigências de uma sede governamental. Mesmo na França, onde já houve uma mudança planejada de capital no século XVII (Versalhes), a ideia de retirar a sede administrativa de Paris voltou à tona em 1960 (VOLDMAN, 1990). Naquele ano, a revista Architecture d'Aujourd'hui lançou um grande projeto visando à construção de uma "Paris Paralela”, uma nova capital para abrigar poderes executivo, legislativo e judiciário franceses. Uma espécie de cidade-satélite com função administrativa, cujo objetivo era desafogar a adensada região parisiense.

Ou seja, uma possibilidade de expansão urbana controlada: um artifício utilizado pelo governo Vargas nos anos 1930 e 1940 para descongestionar a capital paulista; uma reabilitação pós-guerra, regularizada e batizada na Inglaterra como new towns em 1946; um tipo disseminado por outros países mediante dezenas de cidades-satélites - inclusive na França, que não teve a "Paris paralela”, mas, sim, as villes nouvelles. Independentemente da indumentária vestida, as CNs satélites (denominação adotada pelo presente autor) foram uma alternativa face à urbanização periférica e espontânea - “meio clássico de extensão das cidades” (ALLART, s.d., p. 12, tradução nossa) ${ }^{8}$ - ou uma resposta aos grandes conjuntos habitacionais - "guetos sem almas, longe de tudo e, sobretudo, de empregos" (GUYARD, 1980, p. 25, tradução nossa). ${ }^{9}$

Ao criar uma CN satélite, a preocupação primordial é evitar que ela se torne uma cidade-dormitório, dependente da “cidade-mãe”. Para isso, planeja-se em seu domínio um equilíbrio básico entre oferta de moradias e oferta de empregos 8 “[...] moyen classique d'extension des villes [...]"

9 “[...] ghettos sans âme, loin de tout et surtout des emplois [...]” 
(indústria, comércio e serviço). Vejam-se as cidades-satélites na Suécia (1950-1954), chamadas Cidades ABC (traduzido por Casa, Trabalho e Serviços). Nelas, técnicos de planejamento urbano utilizaram a seguinte fórmula:

A CN satélite deveria ter uma comunidade balanceada entre 80 mil e 100 mil habitantes, com densidade de 30 a 80 pessoas por acre, aumentando conforme a proximidade do centro comercial. Haveria uma hierarquização de centros: centro comercial principal, centro administrativo próximo à ferrovia, centro de vizinhança com escola. As habitações foram divididas em $60 \%$ coletivas (edifícios em barra) e individuais (casas isoladas); e as vias adotaram o sistema norte-americano de separação entre vias de pedestres e de veículos. (CERVEO, 1995, p. 44, tradução nossa). ${ }^{10}$

10 "The satellite towns should have a balanced community between 80,000 and 100,000 inhabitants, with density of 30 to 80 people per acre, increasing as the proximity of the mall. There would be a hierarchy of centers: main shopping center, administrative center next to the railway, neighborhood center with school. The dwellings were divided in 60\% collective (buildings in bar) and individual (isolated houses); and the roads adopted the American system of separation between pedestrians and vehicles." 
Cidades novas

Figura 9: Paris paralela

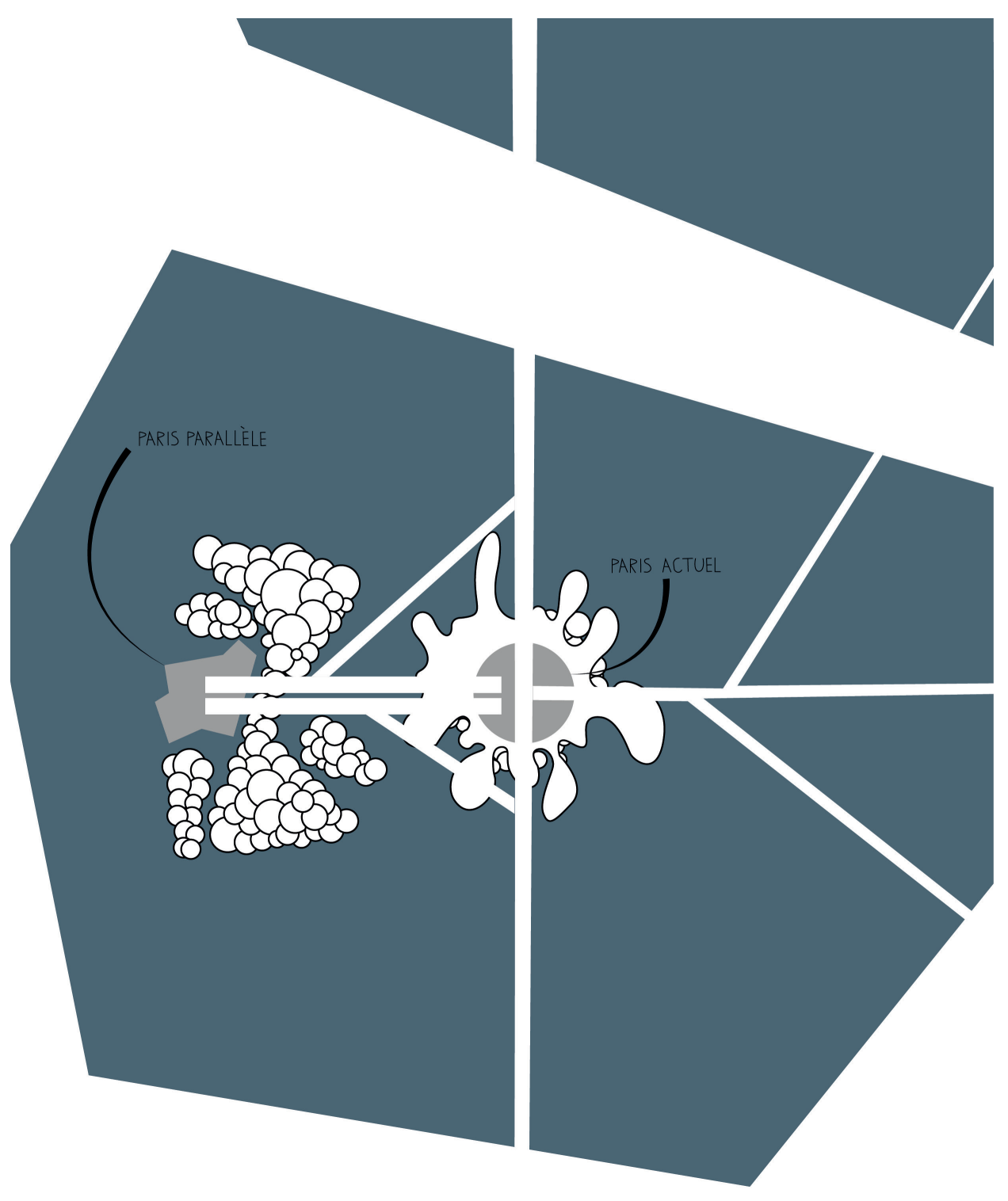


Equilíbrio igualmente imaginado para as villes nouvelles francesas, planejadas para: acalmar as lutas sociais que reivindicavam moradias melhores que la sarcellite (cinturão de conjuntos habitacionais da periferia parisiense); dotar a economia francesa de uma indústria de escala internacional via planejamento territorial; controlar o desenvolvimento urbano na medida do possível, canalizando o desenvolvimento da capital e sua "mancha de óleo"; e promover o equilíbrio emprego-trabalho a fim de reduzir as migrações cotidianas e de melhorar a qualidade de vida de seus habitantes (PAQUOT; PAQUOT, 1977).

Segundo Stéphanie Vermeersch (2005), mais que apenas um equilíbrio entre emprego e moradia, as villes nouvelles deveriam oferecer empregos de alto padrão e qualidade espacial para seus novos habitantes, tornando-se um modelo ideal de vida. Assim, para cada CN proposta, uma vocação particular foi atribuída: Évry seria um centro urbano atrativo; Marne-la-Vallée deveria reestruturar o Grande Leste; Cergy-Pontoise viraria um prolongamento terciário de La Défense; Saint-Quentin-en-Yvelines adequaria o desenvolvimento urbano em curso segundo uma qualidade urbana a oferecer; e Melun-Sénart privilegiaria ser uma cidade verde (BEHAR; ESTEBE; GONARD, 2002).

Dessa forma, as CNs satélites, além da conhecida função de responder ao desenvolvimento das grandes cidades, oferecendo moradia, abrigando indústrias, comércios e infraestrutura adequada, adquiriram a responsabilidade de ser um centro com identidade própria. Ideal que se buscou seguir no Egito, na Escócia, na Tailândia e nos EUA.

No Egito, o processo de controlar o crescimento da capital Cairo data do início do século XX, com as primeiras cidades-satélites, Heliopolis e Maadi (TOULAN, 1979-1980), que se aproximam mais de subúrbios-jardins que de cidades. Posteriormente, vieram: Madinet El Awkaf (1940) e Madinet Nasr (1960). Em 1968, o Plano Regional de Desenvolvimento para o Grande Cairo previa a implantação de quatro novas cidades para abrigar 250 mil pessoas até 1990. O plano efetiva- 
mente foi iniciado apenas em 1975, e tinha por objetivos: redistribuir população e atividades econômicas, proteger terras agrícolas ao longo do rio Nilo, criar novas oportunidades de emprego e melhorar a condição de vida (EGYPT, 1996).

Na Escócia, o período de 1947 a 1966 foi marcado pelo surgimento de cinco CNs: East Kilbride (1947), Glenrothes (1948), Cumbernauld (1955), Livingston (1962) e Irvine (1966). A intenção inicial para a criação desses novos centros foi dispersar a população e as indústrias de áreas urbanas congestionadas, como Glasgow. Posteriormente, somou-se a esse objetivo a função econômica. Esperava-se que essas CNs satélites servissem como áreas de expansão econômica e de desenvolvimento industrial (LLOYD, 1989).

Num dos tigres asiáticos, a política de implantação de CNs para domar o espraiamento das grandes cidades, como a capital Bancoc, foi iniciada em 1963, com uma lei sobre planificação, composta de 64 artigos. Porém, somente em 1970, com o Plano Litchfield, houve uma regulamentação para a criação de CNs. O empreendimento ficaria a cargo de empresas privadas tailandesas - que estabeleciam, regularmente, parcerias com empresas norte-americanas -, encorajadas por empréstimos públicos e isenção de impostos (BARON, 1992). Dentre os objetivos da criação das cidades estavam: reduzir o déficit de moradia; reduzir a taxa de crescimento demográfico; reduzir o tráfego urbano; maximizar a utilização do solo na zona de projeto; criar oportunidades de emprego; diminuir a pressão sobre as infraestruturas da cidade-mãe; e proteger o meio ambiente. Na Tailândia, as CNs satélites deveriam abrigar comércio, indústrias, escolas, moradias, espaços verdes, etc., devendo depender da cidade-polo (localizada numa faixa entre 30 e 80 quilômetros de distância) apenas para certas atividades especiais.

Já nos Estados Unidos da América, a construção de CNs satélites foi uma técnica para canalizar o crescimento urbano e o desenvolvimento da economia (UNITED STATES OF AMERICA, 1981). Essa técnica deveria frear a expansão urbana das grandes cidades e oferecer habitação e emprego de modo igualitário: uma suposição que, na realidade, viu as CNs satélites - como Reston e Columbia, 
próximas a Washington D.C.; Foster City e Redwood Shores em São Francisco; Valencia e Irvine em Los Angeles - receberem, a partir dos anos 1960, apenas uma pequena fração do crescimento populacional (TURNER; SMULIAN, 1974). Ou seja, passos em falso constatados por Frank G. Mittelbach (1973), para o qual a alta expectativa de que cidades novas controlariam e redirecionariam o crescimento de grandes cidades nunca ocorreu. Parafraseando o autor, essas cidades novas tiveram sim é que resolver os problemas sociais que nelas apareceram, além da absorção de grandes investimentos para seu planejamento.

Independentemente do resultado obtido, a CN como controle da expansão urbana apresenta semelhanças à outra, a CN de ocupação territorial (colonização ou fronteiriças). A ordenação da ocupação do espaço pela implantação de cidades, seja nas cercanias de uma grande cidade, seja em regiões áridas, foi um dos campos férteis desse tipo urbanístico. Ao inseminar artificialmente uma rede de núcleos urbanos, busca-se: controlar a imigração interna de um país; colonizar áreas ermas, proteger e defender fronteiras; ${ }^{11}$ desenvolver regiões pouco industrializadas; e abrir novas franjas agrícolas, como na Malásia, onde o governo local construiu, entre os anos 1970 e 1980, assentamentos para urbanização da população rural, modernização e desenvolvimento agrário, diminuindo disparidades entre regiões e grupos étnicos (SALLEH; CHOGUILL, 1992). São políticas adotadas principalmente em países em via de desenvolvimento e ocupação (SAFIER, 1977), onde as CNs são e foram projetos concebidos para responder às necessidades criadas por programas de desenvolvimento regional ou nacional.

Foi assim com as CNs norte-americanas do século XIX, junto à costa oeste. Embora iniciativas privadas, as cidades de ocupação foram planejadas não apenas para servir às necessidades próprias, como também para compor uma rede de assentamentos urbanos de fronteira e incentivar a economia daquela região (HAMER, 1994). Foi assim na Austrália do pós-Primeira Guerra Mundial, quando os soldados de retorno

\footnotetext{
${ }^{11}$ As bastides francesas, além da função de defesa, surgiram para controlar, consolidar e desenvolver os domínios de um determinado poder (real, senhorial, eclesiástico), assim como fixar população em zonas desabitadas, desenvolvendo agricultura e comércio na região (PANERAI et al., 1985).
} 
ao país foram assentados em CNs criadas em áreas pouco adensadas (RUSHMAN, 1976). Foi assim na URSS e suas centenas de navyé goroda. Foi assim no Brasil de Vargas e sua "Marcha para o Oeste”, de Juscelino Kubitschek e sua Brasília, do Regime Militar e sua política de desenvolvimentismo e integração nacional. Foi assim em países de menor abrangência territorial, como Israel e Senegal.

Desde a origem do Estado israelense, em 14 de maio de 1948, o poder local estabeleceu uma política de implantação de CNs como modo de demarcar os limites e demonstrar a posse sobre o seu território. Entre 1948 e 1963, mais de 30 CNs de colonização foram estabelecidas no país, servindo para abrigar imigrantes judeus vindos de todas as partes do planeta - uma distribuição populacional não apenas em zonas agrícolas (EFRAT, 1994). Dessa experiência, nasceram, num prazo de 15 anos, Qiryat Shemona, Afula, Qiryat Gat, Beer Sheva, Ashdod, Elat, Arad e Karmiel.

No Senegal, por sua vez, as CNs de ocupação territorial surgiram inseridas numa política de reforma fundiária, visando ao desenvolvimento geral do país. Para solucionar os problemas fundiários, três níveis de intervenção foram propostos: 1) uma intervenção na zona rural; 2) uma ação organizada ao nível de cidades-periódicas e de cidades novas criadas ex nihilo; e 3) uma política coerente no eixo Dakar-Thiès (WADE, 1973).

Foram CNs de ocupação, colonização e fronteiriças (planejamento territorial) que ficaram, em vários momentos, associadas a outras funções, como a de subsidiar atividades de exploração industrial (função econômica). ${ }^{12}$ Com isso, conseguiu-se, em uma única empreitada, urbanizar e industrializar uma região pouco ocupada ou predominantemente agrícola - fato ocorrido na Índia, Venezuela, Polônia, Hungria, Gana, Gabão e no Canadá, onde a exploração de recursos florestais e minerais, na província de Alberta, durante o século passado, atraiu um grande contingente populacional (BAILLY, 1972).

\footnotetext{
12 Além da exploração mineral, as funções de expansão e ocupação territorial estão interligadas a ações bem definidas, como implantação de ferrovias e rodovias, construção de fortificações, criação de novas zonas agrícolas etc.
} 
Com a vontade de descentralizar a economia - situada, sobretudo, em três grandes cidades: Calcutá, Madras e Mumbai -, o governo indiano propôs quatro CNs empresariais, que nasceram com a função de produção do aço: Rourkela (em Orissa), Bhilai (em Madhya Pradesh), Durgapur (no West Bengal) e Bokaro (em Bihar). Todas planejadas com autonomia em relação a outras cidades, possuindo equipamentos e serviços que pudessem atender à população (KAMBO, 1971).

Na Venezuela, duas CNs empresariais foram estrategicamente propostas: Ciudad Guayana (1960) e El Tablazo (1966). A primeira, localizada no sudeste do país (500 quilômetros de Caracas), tinha por obrigação fixar o marco urbano de crescimento de áreas que continham riqueza natural. Empreendida pela estatal Corporación Venezolana de Guayana, essa CN foi base para o estabelecimento de uma indústria siderúrgica (fundada em 1962) de projeção nacional e internacional. Já El Tablazo, localizada na parte ocidental do país, próxima à cidade de Maracaíbo, deveria criar infraestrutura necessária para o desenvolvimento de um complexo petroquímico, resolvendo, dessa maneira, problemas de emprego na região (BENCHIMOL, 1973).

Inserida na política econômica do governo da URSS, a CN Nowe Tychy (1951), na Polônia, foi implantada próxima à capital Cracóvia, às margens da região industrial do Alto-Silésio, sobre uma pequena vila existente de 13 mil habitantes - sua população prevista seria de 100 mil habitantes (MALISZ, 1961). Já na Hungria, um plano meticuloso de industrialização do país foi colocado em prática. Dividido em dois períodos distintos, ${ }^{13}$ apresentavam três tipos de CNs empresariais: aquelas próximas a minas; aquelas direcionadas a trabalhos metalúrgicos; e, por último, aquelas relacionadas a empresas químicas (HUNGARY, 1984).

Em países africanos, como Gana e Gabão, as CNs empresariais eram tidas como positivas, pois possibilitavam, ao mesmo tempo, atrair atividades econômicas para um ambiente planejado e, com isso, uma produção eficiente. Contudo, sabemos que

${ }^{13}$ O primeiro período (1945-1960) se atrela ao antigo e rígido mecanismo econômico, quando o Estado forneceu de $55 \%$ a $80 \%$ de suporte financeiro para o desenvolvimento estrutural das CNs. O segundo período (1960-1980) cobriu os anos de novos mecanismos econômicos, quando diminuiu o apoio estatal para $36 \%$, ficando o restante sob a responsabilidade de fontes locais. 
tais empreendimentos, realizados por empresas estrangeiras, eram casos isolados, pouco interativos com a realidade local e quase sempre visavam ao beneficiamento de poucos - em Gana, a CN Bibiani explorava minas de ouro e a CN Akosombo extraía recursos naturais para produção de energia (GHANA, 1973). No Gabão, Gamba foi criada pelo grupo Shell para apoiar a obtenção de petróleo da reserva, descoberto em 1956, na região de Port-Gentil - segunda cidade em população do Gabão. Seu plano, de 1967, foi caracterizado pelo tratamento diferenciado da habitação operária em relação a zonas de uso administrativo. Além disso, sua linha de equipamentos ficou aquém do esperado para o desenvolvimento independente e natural de um novo centro urbano (FRANCE, 1970a).

Além desses casos mais recorrentes - CNs administrativas, cidades-satélites, de expansão territorial, empresariais e balneárias (vistas no capítulo anterior) -, outros casos inusitados surgem a partir de funções específicas. É o caso das sauvetés (cidades-rua) na França e Espanha: CNs criadas ao longo do caminho de Santiago de Compostela para garantir abrigo aos peregrinos, segurança aos seus moradores, além de subsídios econômicos para produções agrícolas locais (PANERAI et al., 1985).

Há exemplos de CNs voltadas ao incentivo à educação, como: na França e sua ville nouvelle universitária de Villeneuve d’Ascq (1966), próxima a Lille (uma das nove CNs do período de Gaulle); na Bélgica e sua Louvain-la-Neuve (1968), uma iniciativa privada para receber a sede da Universidade Católica (alunos, pesquisadores, professores, técnicos etc.) e uma população extra de 50 mil habitantes; e no Japão e seu centro universitário de Tsukuda (2000) (BAUDELLE, 2004b).

CNs criadas após catástrofes naturais, como Agadir, no Marrocos, reconstruída após o terremoto de 29 de fevereiro de 1960, quando 70\% de seus bens materiais foram destruídos, conforme relato de Mahamed Ben Attou (BOUMAZA et al., 2006), e New Nsutam, em Gana, reconstruída em novo sítio após desastre ambiental, são CNs criadas em decorrência de conflitos humanos, como os campos de refugiados africanos, abordados nos estudos de Michel Agier sobre o tema (2001). CNs 
criadas como isolamento de pessoas enfermas, como o leprosário Santo Ângelo em Mogi das Cruzes, no estado de São Paulo.

Chamado de “Asylo Colônia Santo Ângelo”, a cidadela foi projetada em 1918 pelo arquiteto Adelardo Soares Caiuby e inaugurada em 1928. Tinha seu parcelamento dividido em “zona sã e zona doente”, contendo, entre essas, uma "zona intermediária”. A primeira era destinada ao pessoal técnico e administrativo sadio, onde se encontravam a portaria, o almoxarifado, a garagem, a administração e demais serviços. A “zona intermediária” abrigava o pavilhão de economia geral, o posto de fiscalização de visitas e o parlatório. A zona doente abrigava o asilo propriamente dito e ali estavam instalados: o hospital, o pavilhão de clínicas, os dormitórios coletivos, as casas para doentes casados, a cadeia, o cassino, a igreja e a parte esportiva. Esses asilos foram projetados visando à autossuficiência, com uma grande área reservada para atividades agropecuárias, destinadas a prover grande parte do consumo alimentar necessário, e ainda dotados de pequenas fábricas e oficinas (FELICIANO, 2008).

Enfim, um leque de possibilidades que revela a versatilidade de como as CNs foram aplicadas. Uma multiplicidade de funções que, juntamente com o desejo de seu(s) empreendedor(es), articularam a causa de origem das CNs. Um dueto que, ao acréscimo do sítio escolhido, se tornou a trilogia de base, a cadeia preliminar que compõe o DNA das CNs. 


$$
y
$$




\section{Cidades novas e o lugar}

Terceira parada: Nova Iorque, no Maranhão; Nova Petrolândia, em Pernambuco; Nova Ponte, em Minas Gerais; e Nova Jaguaribara, no Ceará.

Colete salva-vidas vestidos? Zarpamos em nossa embarcação rumo às próximas CNs. Quatro CNs unidas por um mesmo elemento: a água. Um volume colossal d’água represado por barreiras de concreto, dando origem a enormes reservatórios para gerar energia ou para minimizar a seca no agreste. Lagoas que escondem, em suas profundezas, cidades afogadas. Cidades um dia espontâneas, hoje submersas, fisicamente realocadas para sítios mais altos. Cidades rapidamente construídas para reassentar os moradores órfãos das cidades locadas na baixa.

CNs realocadas, como a brasileiríssima Nova Iorque, situada no estado do Maranhão, a 496 quilômetros de São Luís. Povoado nascido da pecuária itinerante do século XVIII permaneceu, até 1871, com o nome de Vila Nova. A partir daí, passou a ser chamado de Nova Iorque - homenagem feita pelo engenheiro norte-americano Edward Burnett, responsável por realizar, na época, estudos de transporte hidroviário no rio Parnaíba.

Mesmo rio que, nos anos 1960, recebeu a barragem para a instalação da usina da Companhia Hidroelétrica da Boa Esperança (Cohebe). O represamento do Parnaíba afetava diretamente Nova Iorque e Guadalupe, cidade vizinha situada no estado de Piauí: duas cidades que foram inundadas pelas águas represadas e tiveram de ser reconstruídas em sítios protegidos (HOLANDA, 2003).

Em ambos os casos, a nova cidade contou com um plano urbanístico e arquitetônico, sendo a CN de Nova Iorque projetada por uma equipe interna da Cohebe, e a CN Guadalupe pelo escritório carioca Wit-Olaf Prochnik - Arquitetura e Planejamento. Diferentemente de Guadalupe, cujo projeto proposto em 1963 
destoava pela adoção de conceitos modernistas, como a unidade de vizinhança, a nova Nova Iorque foi concebida mediante um pré-estudo cuidadoso de aspectos socioespaciais que compunham a antiga cidade, visando a um plano contextualizado sem necessariamente repeti-la ipsis litteris.

O agenciamento espacial na CN procurou seguir padrões já presentes e comuns aos cerca de 780 cidadãos nova iorquenses. As principais funções igreja e mercado - foram trabalhadas e implantadas a fim de potencializar a urbanidade presente no antigo vilarejo, enquanto outros aspectos foram requalificados: quadras e praças maiores, vias e calçadas mais largas, eixos diagonais para potencializar perspectivas, casas isoladas no lote (artifício desprezado com o desenvolvimento da nova urbe, a favor de antigos hábitos). Cuidados que buscavam evitar espaços segregacionistas e espaços cegos (HOLANDA, 2003), como ruas sem saídas e unidades fechadas. O projeto começou a ser implantado em 1966, prosseguindo por dois anos até sua inauguração em 1968.

Do Maranhão a Pernambuco, chegamos a Nova Petrolândia, a 430 quilômetros de Recife, localizada às margens do rio Itaparica. Cidade formada na segunda metade do século XIX (1887) graças às investidas econômicas trazidas pela construção de uma ferrovia e um cais, feitas a pedido do imperador D. Pedro II em 1870. Em sua homenagem, a antiga Itaparica passou a se chamar Petrolândia.

Um século mais tarde, o desenvolvimento da região ganhava novo impulso. Com a construção da Usina Hidroelétrica de Itaparica, atual Luiz Gonzaga, empreendida pela Companhia Hidro Elétrica do São Francisco (Chesf), uma área de 834 km² foi inundada, acumulando cerca de 11 bilhões de $\mathrm{m}^{3}$ de água, conformando o lago de Itaparica. A grande construção atraiu mão de obra, operários vindos de diversas regiões, aglomerada em acampamentos improvisados na vila de Jatobá. Porém, tal modificação da paisagem também alterou a história de Petrolândia. ${ }^{1}$

1 Petrus, versão em latim para Pedro; land, do vocábulo germânico: terra, gerando Terra de Pedro. 
Figura 10: Petrolândia

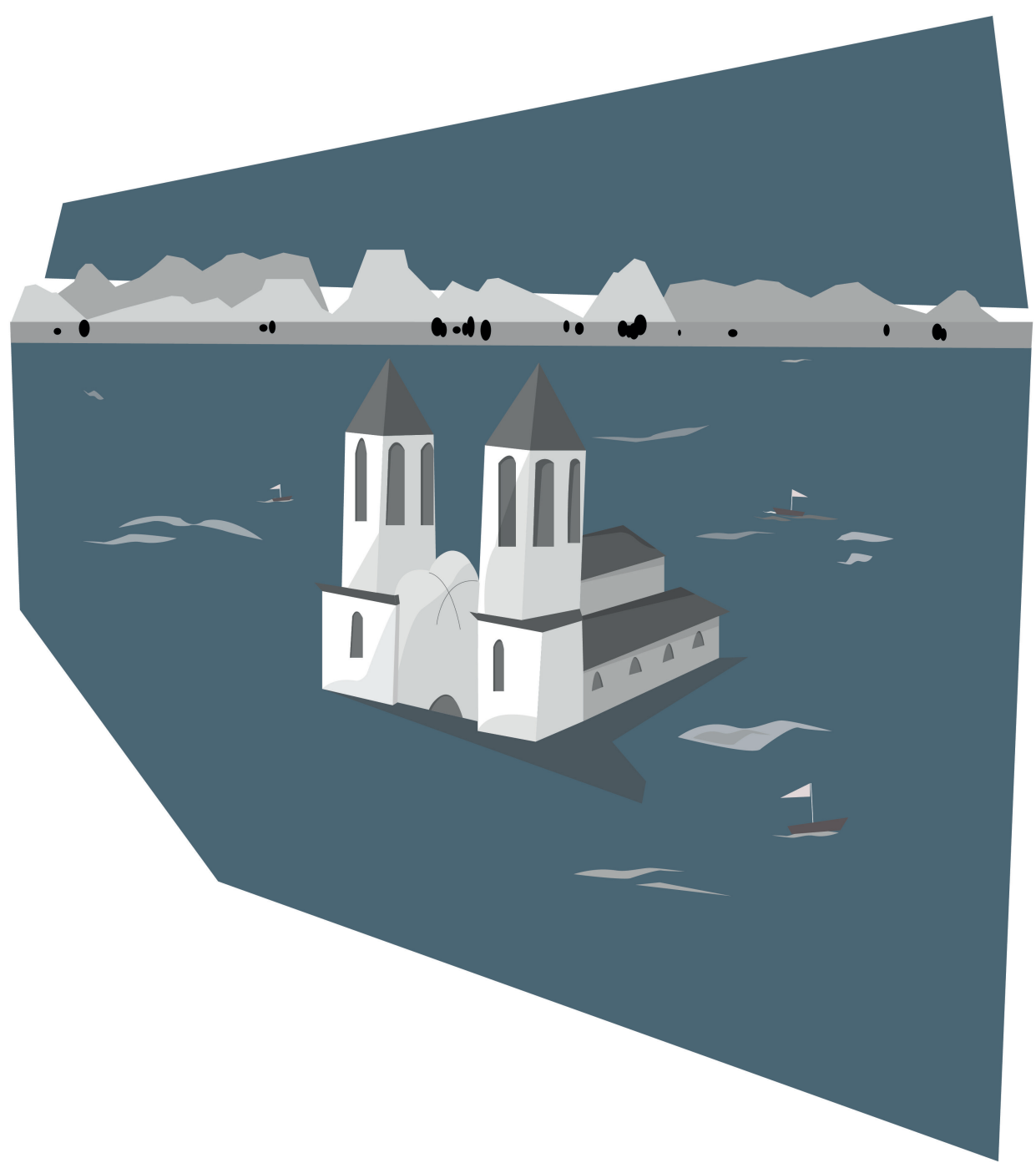


Em 1988, Petrolândia foi desapropriada pela Chesf, período no qual grande parte do antigo município foi inundada, inclusive a própria cidade, obrigando toda a população a deslocar-se para uma área totalmente estranha e adversa. Além da CN de Nova Petrolândia, núcleos menores correspondentes a pequenos povoados foram remanejados, dando origem ao projeto Apolônio Sales e às Agrovilas I, II, III e IV.

Com cerca de 30 mil habitantes, o projeto urbanístico da Nova Petrolândia nome apenas de batismo, já que os moradores insistem em chamá-la apenas por Petrolândia - foi adequado ao terreno às margens do lago, situando a $\mathrm{CN}$ próxima à antiga. Um plano linear em “L”, formado por quadras retangulares, foi agenciado de modo que várias vias tivessem por visual o reservatório, favorecido pelo declive natural do terreno. Rede de abastecimento de água, coleta e tratamento de esgoto e vias asfaltadas foram benefícios antes desconhecidos pela população petrolandense e adquiridos com a nova cidade projetada por profissionais da própria Chesf.

De Pernambuco ao Triângulo Mineiro, caso similar ocorreu na cidade de Nova Ponte (município fundado em 1938), quando seus moradores também foram remanejados para uma nova cidade a três quilômetros da antiga. O processo foi iniciado nos anos 1970, após desapropriação de terras feita pelas Centrais Elétricas de Minas Gerais (Cemig) para a instalação da Usina Hidrelétrica de Nova Ponte, inaugurada em 1982.

Assim como Nova Iorque (MA), em Nova Ponte houve um envolvimento da população no projeto da nova cidade, que se mostrou “ativa na articulação e construção de espaços públicos” (GRUPO HABURB, 2003, s.p.), garantindo, dentre as inúmeras ações, a transferência integral da antiga igreja, tijolo por tijolo.

O plano urbanístico foi realizado por uma equipe da Cemig, prevendo 9 mil habitantes e tendo por conceito projetual a referência ao traçado de cidades do interior - uma avenida principal que cruzaria toda a cidade. A proposta inicial de unificar o novo núcleo - fragmentado em sua origem pelo rio Araguari - foi logo revogada. A pedido da própria população, essa ideia passou por reformulações e as atividades foram locadas conforme as mesmas disposições dos bairros antigos. No total, seis avenidas e 23 ruas asfaltadas foram traçadas, conformando quadras e lotes - sem a 
presença dos quintais avantajados como eram na cidade original -, ocupados segundo um zoneamento primário (residencial, comercial, industrial, lazer etc.), servidos por uma rede de infraestrutura completa (energia, água, esgoto, telefone, iluminação pública etc.). O paisagismo foi contemplado nos canteiros centrais das avenidas, nas praças da igreja e da prefeitura e, principalmente, junto à orla do lago.

Embora todo o processo tenha sido iniciado na década de 1970, a ocupação só se efetivou no início dos anos 1990.

Do Triângulo Mineiro ao Ceará, encontramos Nova Jaguaribara, a 323 quilômetros de Fortaleza, banhada pelo rio Jaguaribe. Diferentemente das três CNs anteriores, o motivo da realocação da sede do antigo município cearense (1694) ocorreu não para o favorecimento da produção de energia, mas para garantir o abastecimento de água das populações do Vale do Jaguaribe. Ao favorecer habitantes afetados por longos períodos de estiagem, característica natural do semiárido nordestino, a barragem do rio e a criação do Açude do Castanhão garantiriam, segundo expectativas, o fornecimento de água em épocas de seca e controlariam possíveis enchentes em tempos de chuvas intensas.

Um debate construído ao longo do século XX, partindo dos primeiros estudos para o projeto do “Açude Público Castanhão”, realizados em 1910 pela Inspetoria de Obras Contra as Secas (Iocs) - atual Departamento Nacional de Obras Contra as Secas (Dnocs) -, até chegar à inauguração da nova cidade, em 25 de setembro de 2001 (PEROTE, 2006).

Todo o processo para efetivação do Açude ocorreu a partir de 1986, com a licitação para a construção da barragem, a verificação dos impactos e a transferência dos povoados afetados, principalmente Jaguaribara, o maior deles, com 4,5 mil pessoas - processo comandado pelo Dnocs em parceria com o governo do estado do Ceará e inserido no Programa de Irrigação do Nordeste (Proine).

A área escolhida para o novo núcleo ficava a 50 quilômetros da antiga Jaguaribara, situando-se às margens do lago artificial, no cruzamento entre duas vias importantes: uma de acesso à BR-116 e outra de acesso ao Açude Castanhão. 
O projeto urbanístico e arquitetônico ficou a cargo da Secretaria de Infraestrutura do Estado do Ceará (Seinfra), tendo por metodologia o planejamento participativo, envolvendo os trabalhos de uma equipe de sociólogos e assistentes sociais, um grupo de projetistas e técnicos em construção (urbanistas, arquitetos, engenheiros, agrônomos, botânicos, geógrafos e paisagistas), além da própria população (GRUPO HABURB, 2003).

A Nova Jaguaribara configura-se por uma malha urbana retangular, com quadras e lotes padrões, sendo traçada sobre o terreno escolhido e com dimensões para atender a 8 mil moradores. Duas vias estruturais definem todo o sistema viário e direcionam o crescimento ordenado da cidade. Seu espaço foi setorizado em zonas definidas - centro cívico (sedes administrativas e igreja); área residencial; áreas comerciais (atacadista e varejista); área de preservação ambiental; área de potencial turístico (na orla do Castanhão) e um distrito agroindustrial -, todas devidamente assistidas por infraestrutura, incluindo aterro sanitário e estação de tratamento de esgoto.

O projeto foi concluído em janeiro de 2001, com sua população reassentada nos meses de julho e agosto do mesmo ano. Detalhe, os mortos foram os primeiros a habitarem a nova cidade, com a inauguração do cemitério em 18 de julho de 2001.

Do Ceará, chegamos a outras regiões do país nas quais o processo de realocação de cidades também aconteceu: Aripuanã, em Mato Grosso (1966); Igaratá, em São Paulo (1969); Pilão Arcado (1974), Casa Nova (1976), Sento Sé (1976), Remanso (1976) e Sobradinho (1976), todas na Bahia; São Simão, em Goiás (1977); Canindé do São Francisco, em Sergipe (1987); e Itá, em Santa Catarina (1996).

CNs tão distantes; CNs tão próximas. Distantes no espaço; próximas pelas circunstâncias: uma segunda fundação. Cidades surgidas para ocupar o espaço funcional, e não físico - de suas homônimas alagadas permanentemente por águas fluviais represadas. Cidades que precisam do tempo e das relações sociais para readquirir uma identidade presente apenas na memória dos moradores e relacionadas a um espaço, agora, inabitável. Cidades afogadas, cidades mortas, que deram origem a CNs em sítios estrategicamente escolhidos para novas realidades. 
Assim, o sítio, ao lado do empreendedor e da função, favorece o nascimento de uma cidade, sendo o terceiro segmento a compor o DNA das CNs: um elemento importante no processo de construção de novos núcleos, podendo ser ele o responsável por despertar no(s) empreendedor(es) o desejo em criá-los ou o fator decisivo na definição de sua função, como veremos na sequência.

\subsection{Sítio: o lócus como gerador de cidades novas}

Para os historiadores Camille Vallaux e Jean Brunhes, em La Géographie de l'Histoire, cidade natural e cidade artificial se diferenciam pelos sítios onde se localizam. A formação urbana da cidade natural foi "espontaneamente determinada pela ação de fatores naturais, tais como cruzamento de vias de comunicação, estuários, baías, vales ou planaltos de fácil acesso, e pelo afluxo de população e da vida econômica que é consequência daquela ação” (apud PENNA, 1958, p. 10-11). Por sua vez, a cidade artificial surgiu ex nihilo, “onde não existia antes qualquer habitação ou, pelo menos, qualquer formação urbana suficientemente desenvolvida para servir aos propósitos” de seu idealizador. ${ }^{2}$ Contudo, discordo dos historiadores por desconsiderarem o sítio como elemento tão importante para a formação das cidades artificiais como o foi para as cidades naturais.

$\mathrm{O}$ alto de uma colina; a proximidade a um rio, a um lago ou ao mar; a presença de jazidas minerais ou águas termais; uma planície extensa; o encontro de terras produtivas; uma baía resguardada; a centralidade de um território; as fronteiras de um país etc. - esses são alguns dos aspectos geográficos, próprios da natureza ou confeccionados pelo homem, que definem a localização de cidades: variantes concernentes a um determinado sítio que nos permitem compreender, em parte, o surgimento de cada CN.

2 Constata-se que Letchworth, a primeira cidade-jardim inglesa, foi implantada sobre um antigo povoado, respeitando antigos percursos e preservando alguns edifícios. As villes nouvelles parisienses foram implantadas sobre áreas de várias comunas (SUDOUR, 1987). Na Hungria, as CNs empresariais surgiram em sítios ocupados por pequenos núcleos (HUNGARY, 1984). Esses são dados que certificam a afirmação de Camille Vallaux e Jean Brunhes. 
O sítio geográfico de uma cidade, seja ela de fundação natural ou artificial, refere-se a aspectos intrínsecos ao local e às suas áreas circunvizinhas, como: relevo, solo, clima e vegetação. O sítio "diz respeito a uma ou mais particularidades do lugar onde se encontra a cidade” (PELLETIER; DELFANTE, 2000, p. 15, tradução nossa). ${ }^{3}$ Opõe-se, portanto, à noção de situação geográfica - uma escala mais ampla de apreensão do território -, colocada por Fábio de Macedo Soares Guimarães, na qual a relação é dada entre a cidade e “outras áreas distintas, próximas ou distantes; não apenas geometricamente, mas com referência a acidentes geográficos, rios, fronteiras, cidades, vias, tendo em vista facilidades ou dificuldades de comunicações, de intercâmbio econômico etc.” (apud PENNA, 1958, p. 10).

Precisamente, as particularidades do sítio provêm de fatos: geológicos (presença de recursos minerais, estabilidade do solo); morfológicos (configuração do relevo); fenômenos climáticos (temperatura, índice pluviométrico, qualidade do ar); hidrológicos (águas de superfície e subterrânea); além da vegetação. São componentes que podem ser modificados conforme as necessidades humanas e, com isso, transformarem-se naquilo que denominamos de sítio criado - uma porção homogênea de espaço construído a fim de assistir necessidades não contempladas pelo sítio natural - por exemplo: muralhas, pôlderes holandeses, parques, aterros, represas, túneis etc.

Cada sítio é único e cada cidade não tem sentido fora do território onde está inserida (PANERAI et al., 1985). Para obtermos uma visão integral do tipo urbanístico em questão, é necessário olhar além do tecido urbano projetado. Devemos olhar para o sítio sobre o qual as CNs foram construídas, atentando para os fatores que contribuíram para sua fundação. Como salientou Philippe Panerai, o sítio "pré-existe à urbanização e mantém-se sob ela”, habilitando-nos de “nele ‘reconhecer’ os pontos singulares, ler os conjuntos, determinar os limites” e, por que não, entender sua história (PANERAI, 2006, p. 48).

Se o fundador de uma CN, devido ao caráter global de sua função dirigente, tem a atenção voltada para as grandes linhas estratégicas do processo, nem por isso deverá

3 “[...] fait référence à une ou plusieurs particularités du lieu où est située la ville.” 
menosprezar as características táticas do sítio em que pretende instalar seu empreendimento. As considerações de topografia, de abastecimento d’água, clima, paisagem, proximidade de zonas agrícolas e áreas para obtenção de materiais de construção sempre foram levadas em conta, desde a mais alta antiguidade até dias recentes.

Tomemos por exemplo o Brasil Colônia. Os portugueses, quando aqui chegaram, escolheram como sítio estratégico para locação de suas CNs administrativas e de defesa territorial as colinas à beira-mar. Direcionada pelas “Cartas Régias” - determinações gerais nas quais havia normas para localização das aglomerações e para seus planos urbanísticos (SANTOS, 1968) -, a opção de sítios elevados na costa brasileira e sua respectiva urbanização se concretizou com respaldo no conhecimento técnico lusitano, adquirido ao longo de séculos no velho continente.

Ao optar por um terreno irregular e mais alto, como no caso de Olinda, os patrícios se diferenciaram dos holandeses, exploradores aqui presentes durante o domínio espanhol sobre Portugal (1580-1640). Ao conquistarem essa região da capitania de Pernambuco, os holandeses desprezaram Olinda - incendiando-a -, e se apossaram de uma área alagadiça - típica nos Países Baixos -, ao lado da pequena Recife, onde projetaram a CN de Maurícia - uma escolha de sítio feita conforme o substrato técnico (repertório urbanístico) de cada cultura: as colinas para atender aos interesses defensivos dos portugueses; os mangues para implantar uma nova civilização dos holandeses, além de servir como porta de entrada para o interior da região, rio como via de penetração.

São vantagens e desvantagens do sítio, dependentes de um saber-fazer cidades, influenciadas igualmente pelas condicionantes de um determinado momento. Sítios considerados estratégicos num momento inicial (defesa), após inovações tecnológicas (técnicas bélicas) ou mudanças de fronteiras (conquista de territórios), passam a ser irrelevantes. Sítios economicamente importantes (reservas minerais) veem suas cidades morrerem após algumas décadas (esgotamento das jazidas), como ocorreu com as CNs de Montdauphin e Arc-en-Senans na França (LACAZE, 1994). 
Embora tais variações possam vir a acontecer, dificilmente locais artificialmente escolhidos apresentarão condições de sítio desfavoráveis, salvo pressa, erro ou predominância momentânea de fatores políticos prementes. A CN de Tucumã (1981), no Pará, por exemplo, surgiu após estudos geológicos do Instituto Nacional de Colonização e Reforma Agrária (Incra) e da Superintendência de Desenvolvimento da Amazônia (Sudam), que detectaram áreas da floresta amazônica possuidoras de terras produtivas (terra roxa) para a implantação de fronteiras agrícolas (ARRUDA, 2009).

Num contexto mais amplo, as posições das introduced capitals foram por demais estudadas, não sendo reflexo das emoções e desejos momentâneos. A localização para uma nova capital na hinterlândia brasileira, como sabemos, antecedeu em muito o período JK (1955-1960), tendo sido especulada no período pombalino (1750-1780) e selecionada pela Missão Cruls entre 1892 e $1894 .{ }^{4}$ O sítio do novo Distrito Federal foi determinante no assentamento fronteiriço, buscando "vigorar e dispersar a razão de ser brasileira e promover as necessidades de uma economia periférica” (BEST; YOUNG, 1972, p. 1044, tradução nossa). ${ }^{5}$

Portanto, ao selecionar um sítio para se implantar uma CN, seu empreendedor (público ou privado) não age ao seu bel-prazer, levado pelo imediatismo. Todo terreno de uma CN é minuciosamente explorado, estudado e planejado para que a adição de um assentamento urbano traga os resultados esperados. Tal levantamento ambiental prévio e respectiva sistematização de dados geográficos contraídos atribuem, segundo Gilles Leloup (1983), uma nova conceituação ao local escolhido: sítio pré-determinado, denominação adotada na língua francesa como site obligé - sítio obrigado, forçado, precisado, escolhido (FRANCE, 1975).

4 Comissão Exploradora do Planalto Central criada pelo governo do presidente Floriano Peixoto em 9 de junho de 1892, sendo chefiada pelo diretor do Observatório Nacional, Luiz Cruls, e composta por técnicos e cientistas diversos. O objetivo de tal Comissão era selecionar e demarcar a área do novo Distrito Federal na região central do país.

5 “[...] to force and to disperse the Brazilian raison d'être and promote the needs of a peripheral economy." 
O sítio pré-determinado pode abranger uma pequena parcela de terra (CNs balneárias) ou um amplo território (CNs de expansão e ocupação territorial). O agente definidor da escala será a função dominante, construída pelas características do próprio sítio e os interesses do(s) empreendedor(es).

Numa escala territorial, destaca-se o programa político australiano de 1972, que buscou descentralizar a ocupação do país por meio da implantação de CNs em regiões desabitadas. Planejadores mais animados propunham a locação de novos assentamentos em áreas inóspitas - terras isoladas "pela distância, aridez, escassez de água, condições extremas de clima ou pela terra não propícia à agricultura” (RUSHMAN, 1976, p. 12, tradução nossa) ${ }^{6}$-, as quais caracterizam grande parte do território australiano.

“Terras virgens” onde, segundo Anatole Kopp (apud MERLIN, 1975, p. 10), 40\% das cidades socialistas foram implantadas na URSS - o restante se concentrou ao redor de grandes centros urbanos como cidades-satélites, as “cidades-sputniks”, a fim de promover o desenvolvimento industrial. Além de agrupar $1 / 4$ da população daquela nação, essa ação de tomada do território pelas CNs foi tida pelo arquiteto e urbanista como o principal meio de valorização das terras antes desocupadas.

Por sua vez, a ocupação do território nos Estados Unidos da América ficou sob a responsabilidade do agente privado, também responsável por escolher o sítio das new communities, definindo seu tamanho e suas infraestruturas. Com isso, as CNs norte-americanas são caracterizadas por sítios definidos pela oferta e especulação de terrenos disponíveis; por uma escala prevista sempre ambiciosa, mas dependente do mercado; e pela localização próxima a uma rodovia não saturada. Fruto do liberalismo americano, “a falta de discernimento na localização dos sítios

6 "[...] by distance, aridity, water scarcity, extreme weather conditions or by land not suitable to agriculture.” 
é um dos pontos fracos das CNs americanas”, como aponta Jean-Paul Loevenbruck (1986, p.II, tradução nossa). ${ }^{7}$

Já em regiões urbanizadas, as cidades-satélites tiveram seus sítios pré-determinados em consonância aos interesses de políticas desenvolvimentistas. As villes nouvelles surgiram planejadas num contexto de reestruturação da área metropolitana das grandes cidades, isto é, um planejamento do território defendido pela Assembleia Nacional francesa em 1963, cujo objetivo era combater o crescimento do desequilíbrio econômico e demográfico nas regiões (AHTIK, 1969). Para isso, novos nós foram criados na armadura urbana de Paris, Lion, Marselha e Lille, com CNs isoladas geograficamente da cidade-mãe - seja por um cinturão verde, um lago ou por condições topográficas -, porém interligadas por um eixo de comunicação rápida (rodovia ou ferrovia).

Para conseguir uma equilibrada condição de desenvolvimento social e econômico e o controle do crescimento das grandes cidades, a criação de cidades-satélites a uma distância razoável da cidade-mãe sempre foi recomendável (IRAN, 1991). Geograficamente, os princípios gerais levados em conta para a localização das CNs satélites devem compreender: características dos limites urbanos existentes; localização para absorver a população excedente da região metropolitana; condições territoriais e ecológicas da área a ser afetada; estudo das condições do solo; fornecimento de água; drenagem de águas e sistema de esgoto; impacto das indústrias etc. Em vários países, a seleção de sítios próximos a cidades grandes seguiu a mesma receita, com maior ou menor cuidado, das new towns de Londres às cidades-satélites ao redor do Plano Piloto em Brasília.

Além de uma visão geral sobre o território ou sobre uma região urbanizada, sítios foram pontualmente escolhidos em áreas desocupadas, particularmente para a criação de polos industriais. Sediaram a transferência de indústrias existentes em regiões congestionadas, como ocorrido na Índia (PRAKASH, 1969), ou deram início a uma industrialização a partir da exploração de recursos naturais encontrados,

7 “[...] manque de discernement dans la localisation des sites est l'une des faiblesses des villes nouvelles américaines." 
fossem recursos hídricos para construção de hidrelétricas, fossem recursos minerais para captação de matéria-prima. Cada qual corroborando para o surgimento de CNs.

Ainda há CNs nascidas em sítio pré-determinado ou au site obligé, em função da exploração econômica dos recursos naturais nele encontrados. Nascidas também pela ausência de núcleos urbanos próximos para fornecer mão de obra; geradas pela necessidade em criar condições de habitabilidade a seus futuros moradores. Foi assim com as dezenas de cidades empresariais criadas no continente africano, dentre elas: Kafue e suas indústrias químicas na Zâmbia, Zouérate e suas minas de ferro na Mauritânia e Lubumbashi e suas minas de cobre no Zaire. Uma multiplicação de CNs em países em desenvolvimento, verificada nos últimos 70 anos, que traduzem o esforço de trazer à tona riquezas até então inexploradas. CNs cuja escolha do sítio foi “o primeiro problema a ser colocado” (MOUSSA, 1972, p. 8, tradução nossa). ${ }^{8}$

Do sítio escolhido ao sítio ocupado, podemos afirmar que o lócus é tão importante para a elaboração do projeto urbanístico como o é para a seleção do terreno da CN.

Quando queremos compreender uma cidade e seu plano urbanístico, e particularmente o caso de uma CN, a análise de sítio é indispensável. Um plano urbano é a expressão de toda a história de uma cidade e não a fotografia de um momento dado de sua evolução. Para Jean-Louis Huot, essa análise "pode começar por examinar o sítio (local exato onde se fez a implantação inicial) e a situação (posição da cidade em sua região)" (HUOT, 1988, p. 11, tradução nossa). ${ }^{9}$

Podemos dizer, portanto, que, na cidade artificial, o lócus escolhido expressa os objetivos precisos de seu fundador. Enquanto uma cidade natural nasce sobre o terreno, uma cidade artificial nasce no mapa e é, em seguida, transportada para o terreno. De praxe, uma CN é uma criação ex nihilo sobre um “sítio virgem”, consagrado outrora à atividade agrícola ou ainda intocado pelas mãos humanas.

8 “[...] le premier problème à poser."

9 "[...] pouvez commencer par examiner le site (emplacement exact où le déploiement initial a été effectué) et la situation (emplacement de la ville dans votre région)." 
No caso das bastides francesas, as estradas e caminhos existentes, curso de rio, possibilidade de um porto ou de uma ponte, construções presentes, disposição irregular do terreno, foram incorporados ao projeto (traçado). Os "procedimentos de agrimensura permitem os primeiros traços seguidos por um parcelamento e a implantação dos edifícios, que uma vez situados marcam o território por vários séculos” (PANERAI et al., 1985, p. 39, tradução nossa). ${ }^{10}$ Trata-se, portanto, de uma relação “natural” entre a CN e os elementos pré-existentes do local.

Uma relação rebatível a qualquer $\mathrm{CN}$, quando encontramos uma preocupação mínima em adequar o projeto ao seu terreno basal. Dessa concordância, nascem cidades implantadas em pontos estratégicos e traçadas conforme as condições do relevo - irregulares em terrenos acidentados e regulares em terrenos planos, salvo exceções.

Também são condicionantes naturais que irão influenciar os projetistas no momento de planejar a futura cidade: topos ou vales de terrenos destinados a áreas para locação do centro ou de parques; faixas verdes às margens de rios - os green fingers do paisagista norte-americano Frederick Law Olmsted (1822-1903) - protegendo os corpos fluviais, separando-os de áreas urbanas; elementos naturais incorporados no projeto de CNs, como em Cergy-Pontoise (França), uma ville nouvelle fundada num conceito de "paisagismo anfiteatro", ou Redditch (Inglaterra), onde os cursos d'águas pré-existentes foram mesclados ao projeto - diferentemente do processo de correção e drenagem usual -, sendo trabalhados de forma a quebrar a monotonia das moradias populares, ou de Adelaide (Austrália), cujo plano do coronel William Light (1786-1839) foi “concebido dentro de uma estética própria para vias, praças e parques-cinturões, implantados conforme o sítio, dando a essa cidade um caráter urbano distinto de outras cidades australianas” (THOMAS et al., 1982, p. 269, tradução nossa). ${ }^{11}$

10 "[...] les procédures d'arpentage permettent les premières traces suivies d'un morcellement et de l'implantation des bâtiments, qui autrefois localisés marquent le territoire depuis plusieurs siècles.”

11 “[...] conceived within a proper aesthetic for roads, squares and greenbelts, deployed according to the site, giving this city an urban character distinct from other Australian cities." 
Figura 11: Cergy-Pontoise

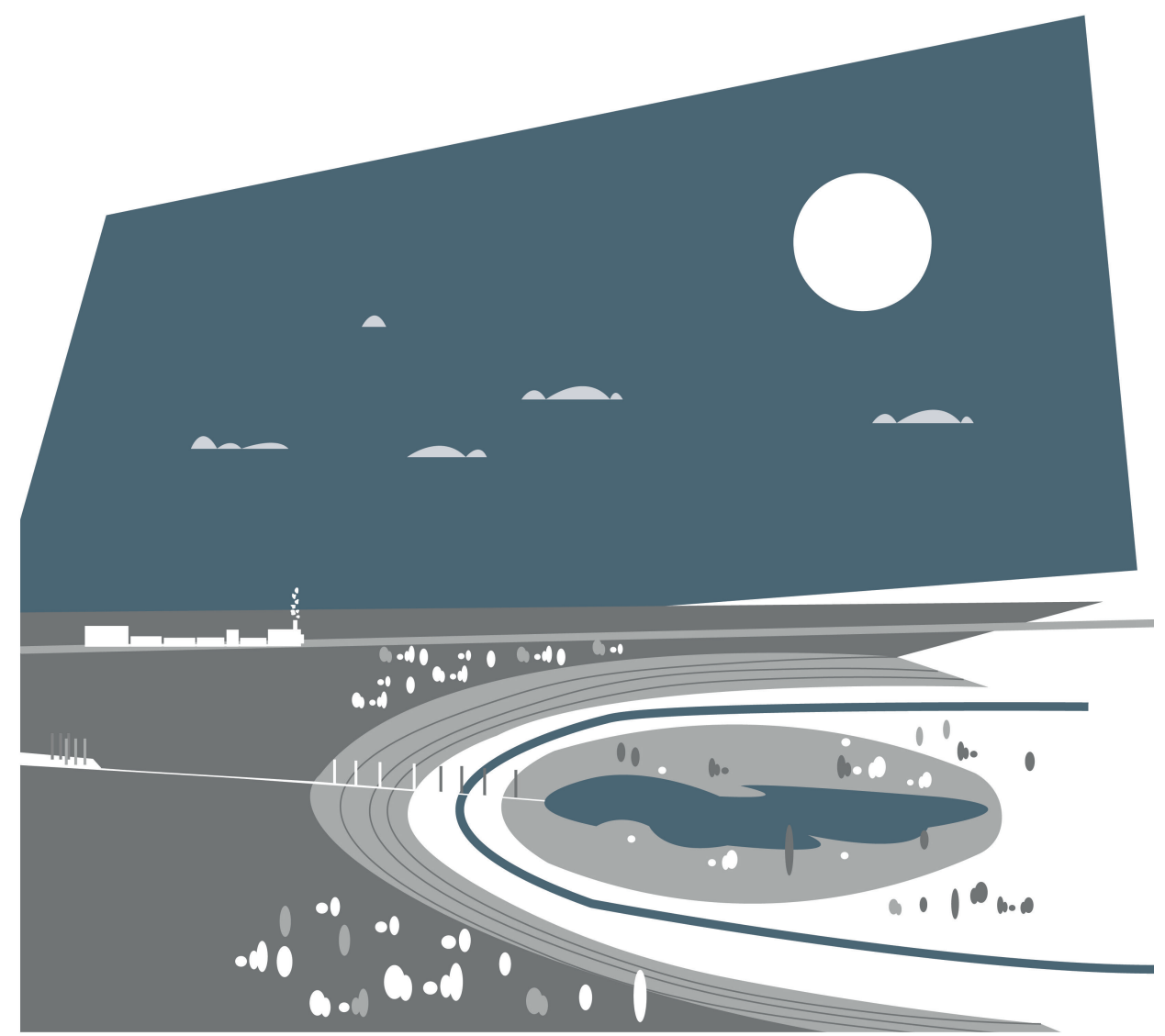

Portanto, o sítio é importante tanto na compreensão dos motivos que fomentaram o nascimento de CNs como também no entendimento dos projetos a elas atribuídos: um elemento muitas vezes despercebido - até mesmo negligenciado por estudiosos, mas de grande relevância para a construção de um conceito sobre CNs. Um pilar que, somado aos outros dois (desejo e necessidade), dará suporte para a materialização das CNs. Uma base de sustentação para que profissionais das mais diversas disciplinas possam elaborar seus projetos de acordo com as vontades de seu empreendedor e as características do sítio escolhido. 


$$
y
$$




\section{Cidades novas e o profissional}

Quarta parada: Águas de São Pedro, São Paulo.

Para relaxamento momentâneo, convido os leitores a um breve passeio pela estância hidromineral de Águas de São Pedro (ASP), uma pacata cidade próxima a Piracicaba, no interior do estado de São Paulo. Uma CN balneária projetada e construída a partir do final da década de 1930, referência nacional pela sua excelente qualidade de vida (BUCHALLA, 2000). Fruto capitalista de uma pequena elite, esse balneário atrai turistas de várias partes do Brasil, que buscam fugir do cotidiano estressante das grandes cidades, revitalizando suas energias. Atraídos são pela qualidade terapêutica das águas minerais, que jorram de suas três principais fontes - Gioconda, Juventude e Almeida Salles -, pela paisagem campestre e pela tranquilidade oferecida no ambiente do menor município do país - com 3,5 km² de área urbana, sem presença de área rural.

Mas nem sempre foi assim. As terras onde esse núcleo urbano se encontra configuravam-se, em fins da década de 1920, como vastos campos de plantação de café, que, nessa época, já apresentavam sinais de enfraquecimento tanto por problemas na economia de exportação quanto pelo desgaste sofrido pelo solo com esse tipo de produção. Impulsionada pela busca de petróleo, como um dos produtos a substituir o café no contexto econômico nacional, a região do município de São Pedro sofreu as primeiras prospecções tendo, porém, como resultado, apenas a obtenção de águas minerais em grande quantidade (RODRIGUES, 1985).

A ideia de transformar a área desses poços em balneários medicinais e, posteriormente, numa cidade para vilegiatura coube a uma sociedade formada por empresários e donos de terras locais, da capital paulista e da cidade de Santos, liderados pelos irmãos Antônio Joaquim de Moura Andrade e Octávio de Moura Andrade. A criação, 


\section{Cidades novas}

em 1935, da empresa Águas Sulphídricas e Thermaes de São Pedro S/A por esse restrito grupo representava um modo de aplicar o grande excedente de capital gerado no auge da economia cafeeira em novas oportunidades seguramente rentáveis.

Figura 12: Águas de São Pedro

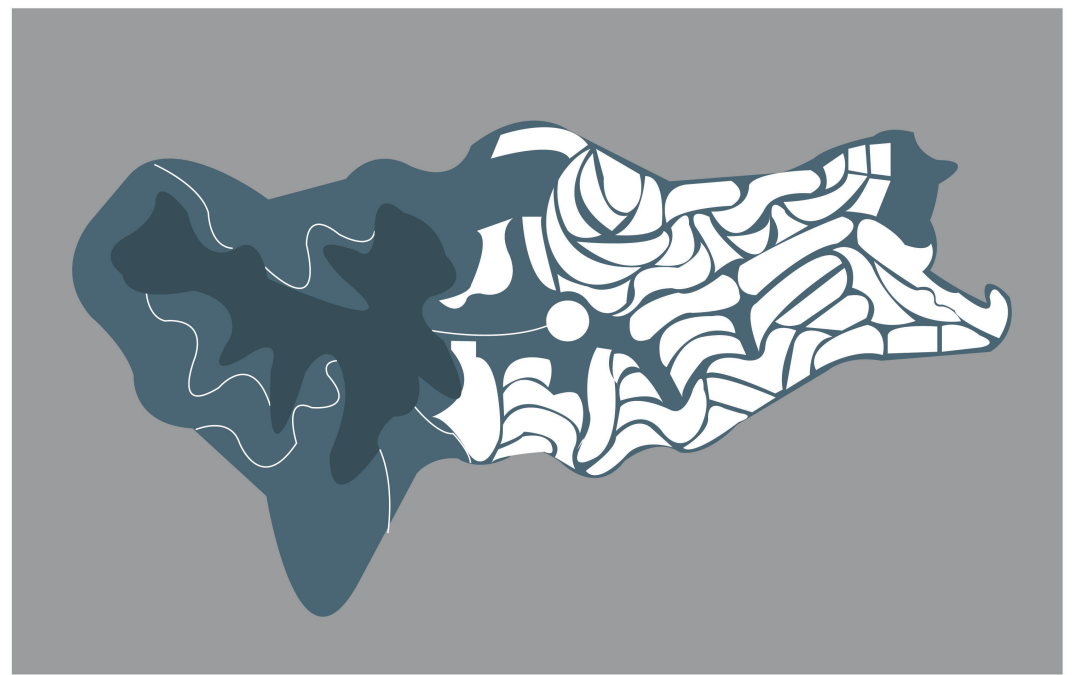

O projeto da cidade apresentou duas etapas: a primeira direcionada à construção do complexo do balneário - “um hotel de luxo, tipo ‘palace’ [não executado]; um grande hotel tipo intermediário [...]; um edifício para termas-sanatorio, onde estão localizados: o balneário, as instalações de fisio e mechano-therapia [...]; um cassino, duas colônias de férias, um restaurante e as demais instalações indispensáveis (buvette, piscinas, quadras de tenis, etc.)” (ÁGUAS SULPHÍDRICAS E THERMAES DE SÃO PEDRO S/A, 1940, s.p.) -, compreendendo uma área de aproximadamente 147 hectares (52\% do total); e a segunda voltada à construção de uma cidade (urbanização e loteamento), com 135 hectares.

A primeira etapa ficou a cargo do engenheiro civil Luiz Camerlingo (19081938) e de outros profissionais da área de pesquisas científicas e de paisagismo, como o médico Jorge Aguiar Pupo, o engenheiro químico Francisco João Maffei 
e o botânico suíço Julius Borchard; a segunda foi realizada pelo engenheiro civil Jorge de Macedo Vieira, auxiliado por Francisco Saturnino Rodrigues de Brito Filho, do Escritório Técnico Saturnino de Brito.

O engenheiro Luiz Camerlingo, ${ }^{1}$ entre 1936 e 1938, foi responsável pelo projeto do Grande Hotel São Pedro e pelo programa de necessidades da CN. Um programa escrito em artigos sequenciados no Jornal Caldas de São Pedro (entre setembro e outubro de 1937), com o título: "Como um architecto e urbanista deve orientar um programma para a organização de um projecto d'uma cidade de aguas e estancia de repouso". Nesse tratado, encontramos desde os cuidados mais gerais até os mais específicos que o construtor deve ter ao realizar tal empreendimento. A riqueza de detalhamentos nos indica a total sintonia entre Luiz Camerlingo e as principais ideias urbanísticas de seu tempo. A participação de Camerlingo, todavia, extrapolou a elaboração desse programa. Em 1936, com o apoio da empresa, o engenheiro foi responsável pela escolha do local onde seria implantada a estância (VIEIRA, 1939), projetando sobre ela o Grande Hotel, estrategicamente posicionado. Concomitantemente, iniciaram-se as obras de construção do aeroporto e do reflorestamento da nascente do córrego Bebedouro, ao lado do hotel.

Quanto ao plano urbanístico, caso tenha havido qualquer possibilidade de Camerlingo ter sido escolhido para ser dele o autor, foi prejudicada em fevereiro de 1938: a aeronave que o engenheiro pilotava caiu quando fazia o trajeto Rio Claro - São Pedro, tirando sua vida aos 30 anos de idade.

Com a morte de Camerlingo, o engenheiro-arquiteto Dacio Aguiar de Moraes assumiu a fase de acabamento do Grande Hotel e também gerenciou, ao lado do arquiteto Jaime Campello Fonseca Rodrigues, as maiores obras arquitetônicas realizadas posteriormente.

\footnotetext{
1 Paulista de Laranjal (1908), Camerlingo diplomou-se em engenharia civil e foi dono de um escritório de construção na capital paulista, onde participou do concurso para a construção do novo Viaduto do Chá, classificando-se em segundo lugar. Como curiosidade, Camerlingo tinha por hobby a aviação, assim como os empreendedores irmãos Moura Andrade, apresentando até brevet de piloto internacional.
} 
Simultaneamente, para o sucesso do empreendimento como estância hidroterápica, era necessário comprovar as reais virtudes das águas subterrâneas - identificando seus elementos químicos - e como incorporá-las a tratamentos de doenças diversas. A primeira tarefa foi repassada ao Instituto de Pesquisa e Tecnologia (IPT), anexo à Escola Politécnica de São Paulo. O responsável por pesquisar as amostras, designado pelo IPT, foi o diretor do departamento de Química, professor Francisco João Maffei (1899-1968). Durante determinado tempo, Maffei manteve seu laboratório na própria estância, de onde emitiu seus relatórios.

A segunda tarefa ficou a cargo dos médicos Jorge Aguiar Pupo, José Bonifácio de Almeida Salles e Franklin de Moura Campos. Recebendo os relatórios elaborados por Maffei, os professores da Faculdade de Medicina de São Paulo e seguidores da Hidrologia Médica - em voga na época - elaboraram laudos especificando os métodos de utilização das águas de acordo com cada moléstia.

Visando a obter lucros também com a industrialização das águas minerais que vinham do solo, exportando-as como água medicinal ou como refrigerante para outras cidades e estados, os irmãos Moura Andrade contrataram os serviços da Companhia Siemens e da Casa Lohner para construir e fornecer máquinas e materiais mecânicos necessários ao processamento e engarrafamento das referidas águas.

Para o projeto paisagístico do balneário, buscando recuperar o terreno devastado por anos de cultura cafeeira, os Moura Andrade recorreram ao Viveiro Manequinho Lopes (Ibirapuera). Este incumbiu o botânico suíço Julius Borchard, recém-chegado ao país, para desenvolver o projeto paisagístico. Mas essa área também contou com a participação do professor Edmundo Navarro de Andrade (1881-1941), da Escola Superior de Agronomia Luiz de Queiroz (Piracicaba). Tendo acabado de elaborar o projeto para o Horto Florestal da cidade de Rio Claro, Navarro foi responsável por comandar o plantio dos milhares de pés de eucalipto no Parque Municipal da estância.

Como suporte às obras e ao consumo interno do hotel e, posteriormente, da futura cidade, também foi pensada a elaboração de instalações subsidiárias. A autossustentabilidade do núcleo começou a se concretizar pela construção de modestos 
galpões nos arredores do balneário para produzir tijolos, telhas, madeiramento, ladrilhos, peças em granito, ferramentas, mobílias como também fornecer alimentos (laticínios, frutas, verduras, carne suína e bovina etc.).

Criando-se as bases necessárias para o funcionamento primário da estância, foi iniciada, em 1938, a segunda etapa do projeto, voltada à urbanização e ao loteamento da CN. O núcleo teria capacidade para atender a uma população de 10 mil habitantes atualmente conta com 2,7 mil moradores, chegando a 34 mil em feriados prolongados.

Jorge de Macedo Vieira (1894-1978)² e sua equipe instalaram base por três anos numa casa na antiga sede da fazenda onde se construía a cidade. Dali, o engenheiro civil comandou o trabalho de levantamento de curvas de nível, metro por metro, de toda a área, para poder fazer o projeto da cidade - após a morte de Camerlingo. Só o trabalho de medição demorou dois anos aproximadamente para ser concluído. Após o levantamento, Jorge passou à parte específica do projeto e à sua execução.

Para isso, contou com o auxílio do Escritório Técnico Saturnino de Brito, responsável pelos estudos de viabilização e execução das infraestruturas de saneamento. Embora tenha sido o engenheiro civil e de minas Francisco Saturnino Rodrigues de Brito Filho (1899-1977) o responsável pela obra de saneamento da estância hidromineral de ASP, os preceitos nela aplicados decorrem do legado deixado por seu pai, o engenheiro sanitarista Saturnino de Brito (projetista do plano de expansão de Santos).

Como partido projetual para ASP, o engenheiro Vieira baseou-se nas experiências para loteamentos em áreas acidentadas que já havia realizado em outras

2 Formou-se engenheiro civil, em 1918, pela Escola Politécnica de São Paulo. Entre 1917 e 1919, estagiou no escritório de planejamento da Companhia City. Essa experiência possibilitou-lhe o contato com as ideias e os trabalhos do inglês Richard Barry Parker (projetista da primeira cidade-jardim: Letchworth, Inglaterra) e, principalmente, ter conhecimento sobre os princípios howardianos da cidade-jardim. Em suas obras posteriores a esse período, nota-se a forte influência que esse ideário exerceu na formação de seu repertório teórico. Exemplos dessa assimilação podem ser verificados nos bairros por ele projetados para as cidades de Campinas, Atibaia, Campos do Jordão e São Paulo, e nos planos urbanos para as CNs de Águas de São Pedro (1937), Maringá (1945), Cidade Balneária de Pontal do Sul (1951) e Cianorte (1955). Em ASP, é possível analisar a integração feita por Vieira entre o urbanismo cidade-jardim - forma - e as especificidades necessárias a uma cidade balneária - função. 
cidades, implantando o futuro loteamento de forma a adequar-se à área determinada. Do mesmo modo, Vieira e Brito Filho usufruíram de todos os recursos urbanísticos - densa arborização, vielas sanitárias como passagens para pedestres, ruas sinuosas de aclive suave, esquinas como pequenas praças, talvegues destacados por sua área verde, cruzamentos principais com rotatórias, larga avenida principal de entrada etc. - para a elaboração de um plano singular.

Consciente das funções que a cidade iria ter, Vieira apenas se preocupou com a largura ampla das vias no eixo central (32 metros), possibilitando acesso fácil ao fluxo de veículos que se dirigiriam ao balneário, ao parque, ao cassino e ao hotel. Tendo como parâmetro a distribuição do trânsito feita para outras estâncias projetadas, achou coerente sua proposta como parkway, enquanto as demais vias ficaram com larguras menores (11 metros), economizando despesas públicas com pavimentação, limpeza, drenagem e conservação.

Do traçado viário, surgiram 55 quadras, sendo 13 destinadas aos estabelecimentos comerciais e aos equipamentos públicos e as restantes, às áreas residenciais. Se o planejamento destacou a maioria das quadras como residenciais, as quadras comerciais, pela necessidade de estarem presentes em locais com maior fluxo de pessoas, foram setorizadas numa das melhores áreas da cidade, entre o Parque Municipal e a Praça Central (rótula de 96 metros de diâmetro).

O loteamento residencial dividiu-se em três tipos diferentes. A primeira área, com posição estratégica próxima ao balneário e ao parque, foi especialmente traçada, diferenciando-se das demais pela faixa única de lotes nas quadras com aberturas para duas vias. As outras duas regiões foram separadas pelo córrego Bebedouro, configurando-se a localizada a sudeste como um setor ocupado principalmente por chalés e casas de veraneio; e a da margem nordeste, devido à sua ocupação por casas operárias - construídas, alugadas ou arrendadas pela empresa para os operários que ajudaram a erguer a cidade -, ficou ocupada em grande parte pelos habitantes fixos da cidade, geralmente de classes média e média baixa. 
A grande dimensão do empreendimento necessitava, entretanto, de mão de obra operária para torná-la realidade. Para a empresa, isso não foi um empecilho. Recém-liberados do campo pela crise na lavoura cafeeira, os trabalhadores locais constituíam-se numa mão de obra abundante e barata (RODRIGUES, 1985). Numericamente, os empreendedores da estância contaram com quatrocentos trabalhadores presentes nas produções fabris e na construção civil.

Em 10 de abril de 1940, o presidente Getúlio Vargas concedeu à estância, mediante um decreto-lei daquele ano, o grau de "estância hidro-mineral e climática, de tratamento e repouso”, também qualificada como “Águas de São Pedro”.

Desse modo, o espírito capitalista dos empreendedores, buscando planejar o balneário não somente pelas necessidades imediatas, mas também pelas de longo prazo, possibilitou criar uma cidade estruturada de forma minuciosa em todos os seus aspectos. Além de contratar os serviços de importantes engenheiros da época (Jorge de Macedo Vieira, Escritório Saturnino de Brito e Luiz Camerlingo), os irmãos Moura Andrade não pouparam esforços para engendrar uma equipe que cuidasse do plano da cidade desde as construções civis até os aspectos técnicos, medicinais, paisagísticos etc.

Uma CN reveladora de ações envolvendo profissionais de áreas diversas a favor do urbanismo de qualidade. Um empreendimento que, nos anos 1930, já contava com o respaldo de um grupo multidisciplinar na confecção global da urbe. Um exemplo aqui exposto para direcionar nossa atenção ao quarto segmento do DNA das CNs: o profissional.

Toda CN deve apresentar, em sua concepção espacial, a participação de um profissional - ou de um grupo deles - responsável por desenhar o novo assentamento, seja seu traçado (vias, quadras e lotes), seja seu tecido (traçado e arquitetura), com menor ou maior grau de detalhamento: um envolvimento individual ou coletivo de projetistas detentores de um saber-fazer cidades, explanado a seguir por meio de exemplos retidos na história do urbanismo. 


\subsection{Os projetistas de cidades novas}

Além da figura do empreendedor, o projetista é uma personagem importante para o entendimento das origens e, particularmente, das características espaciais das CNs. Ao nos debruçarmos sobre a historiografia urbana, destacando dela a temática CNs, os estudos de caso abordados, geralmente os mais significativos, estão diretamente associados aos seus projetistas: Washington de L'Enfant, Canberra de Griffin, Chandigarh de Le Corbusier e Brasília de Lucio Costa. Uma insignificante amostra se considerarmos o universo real de CNs construídas. São centenas de exemplares não mencionados e ainda pouco estudados, cuja falta de conhecimento oculta o envolvimento de profissionais e suas respectivas formação, carreira e contribuição ao urbanismo: profissionais que não devem ser confundidos com mentores de cidades ideais.

Tratadistas e visionários, eles tiveram papel de destaque ao elaborar e propor novos tipos urbanos - teorizados, esquematizados, pormenorizados -, influenciando profissionais de diversas áreas na produção de espaços urbanos inéditos, implantados em diferentes momentos históricos. Contudo, dificilmente algum deles participou efetivamente no desenho de uma $\mathrm{CN}$ e, com isso, não pode ser identificado como projetista. Exemplo é o taquígrafo Ebenezer Howard (1850-1928), idealizador de uma cidade-modelo, que, pela falta de conhecimento técnico, delegou aos arquitetos ingleses Raymond Unwin (1863-1940) e Richard Barry Parker (1867-1947) a tarefa de traçar a primeira cidade-jardim: Letchworth, em 1903.

Portanto, os profissionais em questão são aqueles diretamente envolvidos na projetação de uma CN. Seja sobre uma folha de papel, seja sobre o sítio escolhido, o traçado da futura cidade, com maior ou menor detalhamento, surge pela mente do arquiteto, do planejador, do engenheiro civil, militar ou sanitário, do agrimensor, do topógrafo etc. Sozinhos ou em equipe, portadores de uma capacidade de desenvolver tal atividade, os projetistas traduzem nas CNs todo o 
conhecimento obtido em sua formação profissional e permeado pelas tendências ditadas pela cultura na qual vivem.

Da CN formatada sob a racionalidade filosófica na Antiguidade, passando pela CN enclausurada por fortificações militares na Idade Média e no Renascimento, pela CN embelezada aos moldes do barroco ou do Movimento City Beautiful, ${ }^{3}$ pela $\mathrm{CN}$ tecnicista para atender às necessidades do homem moderno, até chegar à CN democratizada em sua origem por políticas participativas, o que há são mudanças na configuração espacial geradas, segundo Claude Chaline (1985), por transições de diferentes profissões no comando projetivo das CNs ao longo da história.

Na Antiguidade, os pensamentos escritos por filósofos-arquitetos, como Aristóteles ${ }^{4}$ e Platão, que procuraram refletir as divisões lógicas e matemáticas numa sociedade ideal, influenciaram diretamente o teorizador, filósofo, matemático e arquiteto Hipódamo, nascido no século VI a.C., em Mileto. Hipódamo formulou os princípios básicos de urbanismo formal numa época em que essas noções não haviam ainda penetrado o terreno das realizações práticas. Embora o esquema geométrico - desenho formal, ortogonal ou em grelha - fizesse parte da realidade de culturas no Egito, na Mesopotâmia e na China há milênios, Hipódamo utilizou-o em sua prática urbanística - tradições geométricas e concepções aritméticas que “os

3 City Beautiful (cidade-monumento ou cidade monumental) foi um tipo urbanístico recorrente no início do século XX, utilizado, principalmente, por arquitetos norte-americanos, como Daniel Hudson Burnham (1846-1912). Essa tipologia urbanística, originária do urbanismo barroco e dos planos de L'Enfant para Washington e de Haussmann para Paris, apresentava como principal característica o redesenho do centro cívico das cidades, atribuindo-lhe um valor simbólico de poder. A valorização da figura pública perante a sociedade dar-se-ia mediante o traçado urbanístico geométrico e simétrico, a localização estratégica dos edifícios e monumentos e a arquitetura monumental dos edifícios públicos. Aplicada em cidades norte-americanas, como Chicago, Cleveland e São Francisco, essa tipologia também foi aplicada ou idealizada para inúmeras CNs capitais de colônias inglesas (Nova Délhi, na Índia; Canberra, na Austrália; e em inúmeras colônias no continente africano) e para as capitais de regime ditatorial, como Roma, de Mussolini; Berlim, de Hitler; e Moscou, de Stalin.

${ }^{4}$ Aristóteles escreve sobre urbanismo em sua Política, estabelecendo os três aspectos fundamentais da matéria sob os títulos de "higiene, defesa e circulação". Curiosamente, o filósofo já assinalava, na época, a incompatibilidade dos dois últimos, pois o plano irregular, como se demonstrou na Idade Média, é favorável à defesa, mas prejudicial ao fluxo. 
pitagóricos haviam transmitido do Oriente [...] e, especialmente, a veneração do número três” (PENNA, 1958, p. 42). Do mesmo modo, ele absorveu o "urbanismo prático” da Mesopotâmia, incorporando sistemas de infraestrutura - canalizações, esgoto, orientação e comunicações - em CNs por ele projetadas, como Mileto (reconstruída após ataque persa em 494 a.C.), Pireu (439 a.C.) e Rhodes (408 a.C.). Estas, bem como as demais cidades seguidoras da malha hipodâmica, apresentavam por características: traçados regulares, ortogonais, orientando a implantação dos edifícios; ágoras fechadas e portificadas; coordenação entre edifícios públicos para obter sentido de unidade urbanística; e terraplanagem em terraços e sítios acidentados, ligando desníveis mediante arquibancadas e escadarias (OLIVEIRA, 2007).

São as diretrizes verificadas no plano para Alexandria do século IV a.C., realizado pelos arquitetos Dinócrates de Rhodes e Soscrato de Cnido: uma cidade portuária organizada em uma malha quadriculada cardo-decumano cortada pela Canope avenida principal com cinco quilômetros de extensão e 30 metros de largura. No centro da urbe, à beira do porto, os arquitetos implantaram o palácio real, além de uma série de edifícios-monumentos, como teatro, biblioteca, museu, ginásio e o estádio.

Tipo semelhante de configuração urbana adotado por oficiais e agrimensores europeus - os lotisseurs - entre os séculos XIII e XV. O uso da quadra-tipo compondo uma malha cercada por muralhas, centrada por um espaço vazio (a praça) e limitada pela topografia do sítio escolhido é característica peculiar a qualquer $\mathrm{CN}$ desse período. Ou seja, um modo de fazer cidades que encontrou nos engenheiros-militares (italianos, alemães, espanhóis, franceses, portugueses etc.) o profissional responsável em projetar cidades após o século XV, especialmente as CNs de defesa, ocupação e expansão territorial.

Um dos expoentes dessa geração de projetistas foi o francês Sébastien Le Prestre (1633-1707), o marquês de Vauban. Durante o reinado de Luís XIV (16381715), Vauban trabalhou por 40 anos ao lado do Rei Sol como Comissário Geral das Fortificações, construindo um importante e vasto repertório sobre técnicas de ataque e defesa pelas fortalezas. 
Os 53 pequenos núcleos projetados em diferentes sítios foram "testemunhas do saber e do saber-fazer de um homem múltiplo: por vezes engenheiro, arquiteto e urbanista” (WARMOES; SANGER, 2007, p. 15, tradução nossa). ${ }^{5}$ As cidades de Vauban revelaram o seu rico conhecimento sobre técnicas militares, colocadas em prática nas fortificações impenetráveis. Distantes de simples cinturões envolvendo um núcleo urbano, as CNs de defesa do marquês surgiram protegidas por muralhas construídas a partir de estudos empíricos - envolvendo física, matemática e geografia - e implantadas após trabalhos topográficos, sobrepondo muros estelares rotacionados em diferentes patamares.

Esse conhecimento se tornou recorrente nos países europeus e exportado para territórios colonizados no novo continente. No Brasil, tal saber foi transmitido, destacadamente, a partir da fundação das Escolas Militares de Engenharia nas cidades de Salvador e Rio de Janeiro, no século XVIII. Nelas, foram introduzidos ensinamentos reguladores de arquitetura e urbanismo, permeados de conceitos renascentistas e barrocos, como: arquitetura com fachadas similares, traçado ortogonal para as vias urbanas, definição das dimensões e formas dos lotes (REIS FILHO, 1968). Os engenheiros militares eram tidos, entre outras coisas, como os “funcionários do urbanismo” português, responsáveis por “fazer cidades”. Suas ações eram direcionadas, mais especificamente, para levantamentos de campo e remodelações ou construções fortificadas novas, sob a forma de estrelas, abrigando, em seu interior, pequenos núcleos urbanos (BUENO, 2000). Contudo, o "saber fazer cidades” continuou no país sendo mais empírico que teórico.

Vilas e cidades eram projetadas por engenheiros e implantadas pelo "ruador" - que executava as ordens do engenheiro - em pontos até então isolados da nação, “subordinadas a um protótipo cujo traçado possuía conceitos barrocos (ruas retilíneas, praças bem delineadas, uniformidade de elementos arquitetônicos) facilmente

5 “[...] témoins du savoir et du savoir-faire d'un homme multiple: parfois ingénieur, architecte et urbaniste." 
adaptáveis às condições locais”, segundo afirmação de Roberta Marx Delson (apud FRIDMAN, 2005, p. 56).

A partir do século XVIII, com as especializações do conhecimento e a respectiva segmentação em diferentes ciências, as profissões passaram a ser determinadas pelas academias. Na pioneira França, surgem a École des Beaux-Arts (Escola de Belas Artes), a École des Ponts et Chaussées (Escola de Pontes e Caminhos) e a École Polytechnique (Escola de Engenharias), todas formadoras de profissionais aptos a exercerem a função de projetista (CLAVAL, 2001). Todavia, cada qual tinha enfoques específicos sobre as questões urbanas - fosse pela composição estética, fosse por aspectos práticos, como infraestrutura -, fomentando, com isso, a diversidade de exemplares e tipos de cidades criadas.

Nos Estados Unidos da América, as Schools of Landscape Architecture and City Planning (Escolas de Paisagismo e Planejamento Urbano) diplomaram arquitetos-paisagistas que ditaram o modo de projetar cidades em fins do século XIX e início do século XX. Warren Henry Manning (1860-1938), empregado do renomado paisagista Frederic Law Olmsted (1822-1903) entre 1888 e 1896, projetou a CN de Gwinn (Michigan) em 1906 - comunidade planejada para a firma Marquette Iron Range -, com a preocupação em adequar o plano urbanístico às condições oferecidas pelo sítio. Elbert Peets (18861968) planejou, durante o New Deal, a cidade de Greendale (Wisconsin) - núcleo urbano com 3 mil moradias para 12 mil habitantes -, preservando antigas casas rurais do sítio e ligando centro da cidade e cinturão verde por meio de caminhos de pedestres. Anos antes, Peets já havia projetado outra CN, Kohler (Wisconsin), na companhia do planejador alemão Werner Hegemann (1881-1936), ${ }^{6}$ de quem foi assistente. Na lista, acrescenta-se John Nolen (1869-1937), o primeiro americano a se identificar como city planner, proprietário de um escritório responsável pelo desenvolvimento de “mais de

6 Peets e Hegemann escrevem juntos o livro The American Vitruvius: an architect's handbook of civic art, publicado em 1922. Um verdadeiro atlas ilustrativo no qual os autores trabalham temas como: resgate da arte cívica iniciado por Camillo Sitte (1843-1903), desenho de praças e espaços públicos em cidades europeias, agrupamento de edifícios, composição de vias, paisagismo de parques, planejamento urbano como desenho totalitário, finalizando a obra com uma análise do plano urbanístico da capital Washington. Um referencial projetivo para inúmeros profissionais. 
400 planos para CNs” (MARTIN, 1999, p. 69), dentre eles a CN de Madison (Wisconsin), parcialmente construída em 1907.

Figura 13: Neuf Bisach

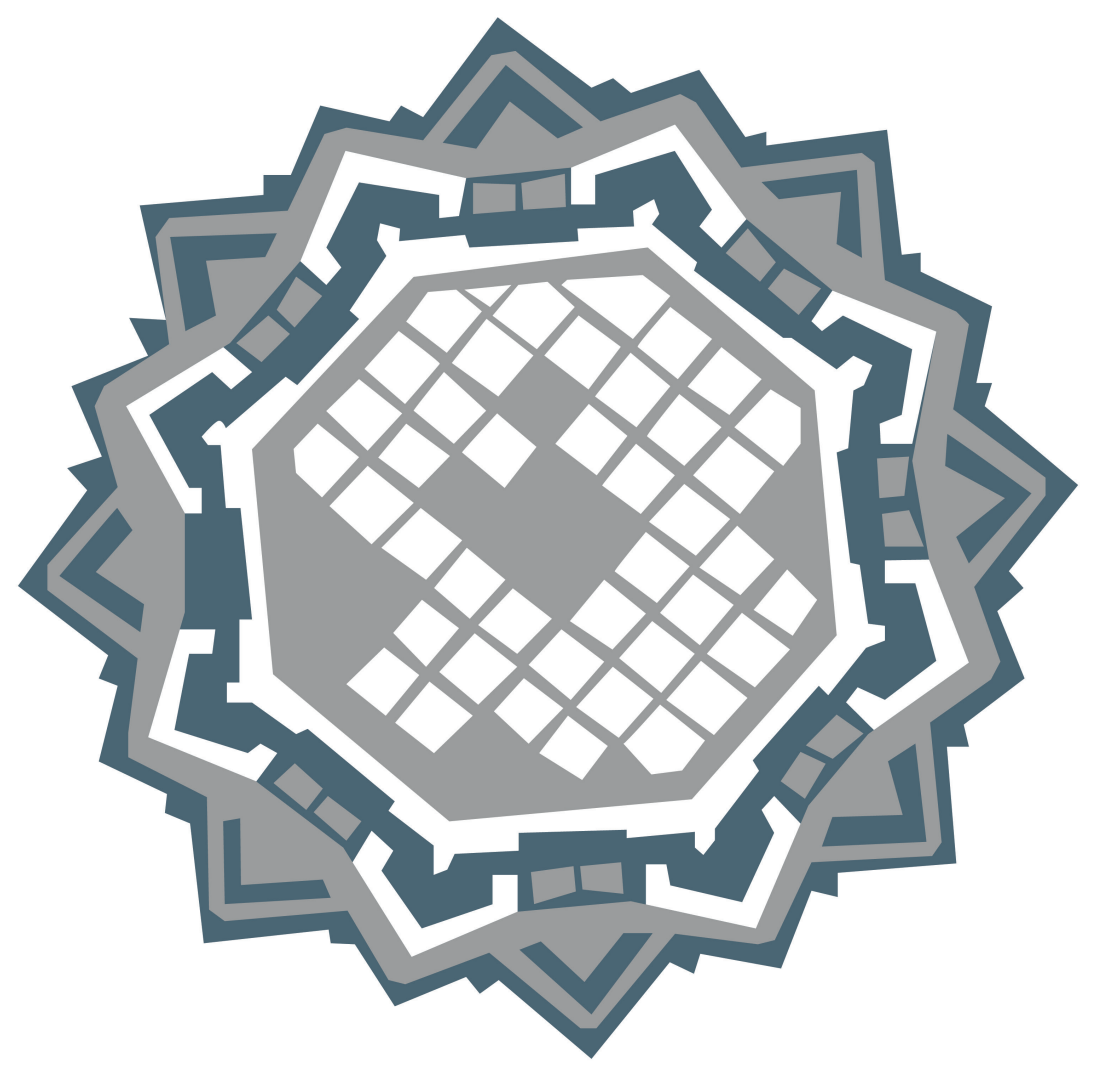


De volta ao velho continente, a cidade como espaço cênico era trabalhada por arquitetos formados na École des Beaux-Arts de Paris. Exemplo disso foi a "Cidade Mundial”, projetada pelo arquiteto francês Ernest M. Hébrard (1866-1933) em 1912. Um empreendimento encomendado por Henrik Christian Anderson, um rico escultor norte-americano que visionava criar uma cidade para a paz mundial. Diferentemente de uma cidade-modelo, tal como a cidade-jardim (um protótipo destinado a ser reproduzido), essa cidade seria uma verdadeira capital mundial, reunindo sua elite em uma cidade única, prevista para ser implantada ao lado de Bruxelas (Bélgica).

Seu plano constava de eixos simétricos e uma longa perspectiva central. Os três nós urbanos sucessivos da cidade seriam uma área destinada aos Jogos Olímpicos, um complexo de artes e um centro de comunicações construído ao redor da monumental Torre do Progresso, de onde jornalistas do mundo inteiro divulgariam as novas descobertas da ciência assim como os avanços morais e artísticos da sociedade. Como discípulo da Beaux-Arts, Hébrard se preocupou com o sistema de trânsito, hierarquizando a trama de vias arborizadas com avenidas, ruas e rotatórias para organizar o tráfego, largas calçadas e áreas de estacionamento, canais para navegação e transportes subterrâneos. Também se preocupou com questões higienistas ao adotar inúmeros pequenos parques e abundância de luminosidade.

Foi uma visão artística sobre a cidade que começou a perder campo frente a um urbanismo funcionalista e tecnicista adotado por arquitetos e engenheiros, mesmo por aqueles formados na Beaux-Arts de Paris, como Tony Garnier (18691948). A partir de um trabalho de graduação, Garnier projetou, entre 1901 e 1904, a cité industrielle (cidade industrial), que se tornou pública apenas em 1917, com a edição de sua obra Une cité industrielle étude pour la construction des villes. O trabalho apresentava gravuras do projeto da cidade industrial e sintetizava os principais elementos que deveriam constituir a cidade: administração e estabelecimentos públicos, escolas, estabelecimentos sanitários, estação ferroviária, fábrica e hidrelétrica (todos projetados em concreto armado). Incorporando instrumentos de zoneamento, saneamento, edificação, uso social do solo urbano, entre outros, o 
projeto de Garnier refletia a evolução pela qual a escola urbanística passava naquela época - uma intensa produção de tipos de novas cidades, que tinha por objetivo principal melhorar as condições de vida urbana pelo conhecimento técnico-científico.

No Brasil, nesse momento, os profissionais encarregados de projetar cidades formavam-se ou na Escola de Belas Artes do Rio de Janeiro ou em Escolas Politécnicas, como a de São Paulo. Aberta em 1894, a Politécnica de São Paulo inovou o ensino de engenharia e arquitetura no Brasil. Diferentemente das Escolas do Rio e da Bahia - onde o ensino fundamental se dava na Politécnica e os específicos eram divididos entre as Escolas de Minas e Pontes ou Belas Artes, para os futuros profissionais que desejavam a arquitetura -, essa instituição se espelhou nas escolas de Zurique e Karlsruhe (Alemanha), unificando o ensino do curso fundamental e dos cursos especiais em uma única escola (FICHER, 2005). Aproximando as diversas ciências, possibilitando uma integração entre as áreas e a construção de um pensamento globalizante, o modelo visava a formar profissionais, engenheiros-arquitetos, aptos a responder às necessidades apresentadas pela cidade de sua época, como coloca Sylvia Ficher em seu livro Os arquitetos da Poli: ensino e profissão em São Paulo:

[...] o curso de arquitetura da Politécnica visava formar engenheiros-arquitetos preparados para projetar e construir edificações, em contraste com seus colegas engenheiros civis, que deveriam projetar e construir obras de engenharia: pontes, viadutos, portos, canais, estradas de ferro e de rodagem, redes de água e esgoto etc. [...] divisão era razoavelmente clara no que dizia respeito ao ensino. (FICHER, 2005, p. 26). 
Pois, na prática, mesmo alguns engenheiros-arquitetos formados na Poli se especializaram em questões urbanas, ${ }^{7}$ como Luís Inácio de Anhaia Melo (18911974) e Francisco Prestes Maia (1896-1965), responsável pelo projeto da CN de Panorama, em 1946, no interior de São Paulo.

Paralelamente ao trabalho volumoso de engenheiros e arquitetos, temos conhecimento de outros profissionais que também atuaram no campo do urbanismo, formados em engenharia sanitária, engenharia agrônoma e mesmo em cursos técnicos para agrimensores-topógrafos. Saturnino de Brito (1864-1929), responsável pela expansão de Santos e dezenas de planos de reestruturação urbana país afora, era sanitarista. Bernardo Sayão Carvalho de Araújo (1901-1959), “plantador de cidades e estradas”, dentre elas a CN de Ceres (GO) e a rodovia Belém-Brasília, era engenheiro agrônomo. Germano Robach (ignoto-ignoto), autor da demarcação da CN de Cosmorama junto à ferrovia Araraquarense (SP) em 1931, era agrimensor.

Porém, se a figura de um profissional isolado, ou destacado, na projetação de CNs era evidente até a primeira metade do século XX, após a Segunda Guerra Mundial essa posição passou a ser dividida com equipes multidisciplinares tanto no exterior como no Brasil. Arquitetos, engenheiros, agrimensores, topógrafos foram contratados para compor, juntamente com outros profissionais - geógrafos, psicólogos, economistas, sociólogos, antropólogos, historiadores etc. -, grupos que iriam planejar e desenhar novos núcleos urbanos. Françoise Choay, em artigo sobre as villes nouvelles, certifica tal transformação nos anos 1960, quando sua realização foi apoiada por pesquisas e estudos das ciências sociais (CHOAY, 1988). Planejadores e arquitetos descobriram a panaceia das equipes pluridisciplinares; psicólogos e sociólogos produziam, com agitação, problemas, soluções e a terminologia adequada.

7 Podemos averiguar um aumento das questões urbanísticas na formação de engenheiros-arquitetos com a matriz em vigor nos anos de 1926 a 1931, quando o urbanismo "era coberto por um programa detalhado, tratando, entre outros aspectos, de: urbanização, a cidade como um problema de governo, a legislação urbanística moderna, a rua, a circulação, os centros urbanos e as praças, os quarteirões, os bairros e sua especialização (zoning), as cidades-jardim, os planos regionais e nacionais, a maioria desses temas exemplificada pela experiência inglesa e americana” (FICHER, 2005, p. 199). 
Grande parte dessas equipes era ligada a órgãos públicos, escolhida para concretizar políticas de controle de expansão urbana, de ocupação territorial e de desenvolvimento econômico.

Na URSS, como já citado, havia o Comitê do Estado para Construção Civil e Arquitetura (Gosgrajdanstroi), responsável pela política de urbanismo, com 18 órgãos assistentes e um total de 200 mil pessoas trabalhando com questões urbanas (MERLIN, 1975). No Japão, as CNs de Tama (1965) e Tsukuda (2000) ficaram sob os cuidados da Corporação de Desenvolvimento Habitacional e Urbano (DUCON; YOKOHARI, 2006). Na Suécia, planejadores regionais construíram uma extensiva rede ferroviária ligando as cidades-satélites com o centro de Estocolmo, comandados pelo arquiteto Sven Markelius na década de 1950 (CERVEO, 1995). Na Índia, a maior parte das CNs foi concebida por planejadores e construída por autoridades de setores do desenvolvimento (PRAKASH, 1969). Na Venezuela, os projetos de algumas CNs foram desenvolvidos pelo órgão público Corporación Venezoelana de Guayana com o auxílio de equipes vindas do Instituto de Tecnologia de Massachusetts (MIT) e da Universidade de Harvard, ambas instituições norte-americanas (TURNER; SMULIAN, 1974). Na Argélia, a CN de Ali Mendjeli apresentou dois projetos: um de 1974, confeccionado pelo governo argelino com seu Escritório de Estudos Nacionais (CADAT) e auxiliado por técnicos tchecos; outro de 1990, realizado pelo Centro de Estudos e de Realizações em Urbanismo (URBACO), um órgão estatal (CHERRAD apud BOUMAZA et al., 2006). Mesmo nos EUA, onde as CNs ficaram a cargo de empreendimentos privados, os projetos foram realizados por equipes de profissionais de diversas áreas, como na CN de Columbia (1963), cujo fundador, James W. Rouse, reuniu uma equipe de 18 profissionais (LACONTE et al.; 1982). No Brasil, além dos exemplos de CNs de realocação, nas quais a participação de equipes multidisciplinares foi recorrente, temos a CN de Dassópolis - núcleo urbano não executado para 2,5 mil habitantes e com função de colonizar a Amazônia -, elaborada por 
uma equipe de professores e pesquisadores da Universidade Estadual de Campinas (Unicamp) na década de 1980 para o Projeto Cotrijuí-Norte.

Quando não havia a presença de tais instituições públicas, escritórios privados de arquitetura e planejamento urbano eram convidados pelo próprio Estado ou participavam de concursos públicos destinados a projetos de CNs.

Na China, o Escritório de Administração em Planejamento Urbano de Xangai realizou um concurso internacional para contratação de empresas estrangeiras, visando ao planejamento de dez CNs (MING, 2003). Dentre elas, estão: Nanhui, desenhada pelo escritório francês Arte-Charpentier (do arquiteto Pierre Clement) no início dos anos 1990; Nan Cha, realizada por Campenon Bernard S.G.E. e pelo escritório de arquitetura de Ricardo Bofill em 1993; e Tianjin Commercial Development Area (TEDA), com projeto inicial canadense em 2001.

Ainda na Ásia, o mesmo procedimento foi adotado na Indonésia, com a CN de Bekasi, elaborada por arquitetos franceses em 1982. Na Tailândia, com a CN de Muang Thong Tani, de concepção australiana e realização francesa (Bouygues Société), entre 1990 e 1995. E na Malásia, com a CN administrativa de Putrajaya, projeto dos franceses Dubus e Richez, em fins dos anos 1990 (PETIT, 2002).

Outros escritórios também trabalharam na concepção de CNs. O escritório grego Doxiadis Associates trabalhou no plano das CNs de Islamabad (capital do Paquistão), Surchinar (CN industrial no Iraque), Kafue (Zâmbia) e Tema (Gana). O escritório de arquitetura francês Kalt, Pouradier Duteil et Vignal projetou Malbaza (Nigéria). O grupo formado pelos urbanistas M. P. Bredsdorff, S. E. Rasmussen e M. R. Drayby desenhou a cidade-satélite dinamarquesa de Albertslund. E mesmo um projetista de campos de golfe, Jack Nicklaus, foi contratado para traçar a CN de Bumi Serpong Damai, na Indonésia (FIRMAN, 2004).

Na França, as villes nouvelles foram envoltas por uma rica e densa equipe de profissionais, desde seu planejamento original até o desenho dos edifícios de cada cidade. Na fase inicial, Paul Delouvrier, encarregado de implantar as CNs francesas, foi auxiliado por: Jean Millier (autor da CN de Abidjan, na Costa do 
Marfim); Jacques Michel (politécnico envolvido no Plano de Melhoramento de Paris, de 1960); Serge Goldberg (estudioso do urbanismo norte-americano e especialista em redes rodoviárias); Michel Piquart (idealizador do plano urbanístico de Constantine); e Jean Vaujour (prefeito e conhecedor das coletividades da periferia de Paris) (TILLIETTE, 1985). Eram altos funcionários, unidos a engenheiros, arquitetos, economistas, geógrafos, sociólogos e estagiários universitários, contratados para elaborar os projetos, separados em dois ramos de atuação: urbanismo de estudos (mais arquitetos) e urbanismo operacional (fase de dependência mútua).

Reunidos em Établissements publics d'aménagement des villes nouvelles françaises (EPA), os primeiros trabalhos foram organizados no Esquema Diretor de Estruturas (1965-1968), que definiu o programa e a parte de planejamento e organização do espaço de cada CN. Em Cergy-Pontoise, por exemplo, o processo projetivo ocorreu a partir de células. Cada célula trabalhava com uma área específica e continha um engenheiro, um arquiteto e um desenhista. Essas células se ocupavam da concepção dos bairros, do urbanismo operacional, do planejamento dos espaços públicos, da arquitetura, das diretrizes operacionais, da assistência aos construtores etc. Havia também equipes formadas por um arquiteto, um engenheiro, um paisagista e um sociólogo. Nos anos 1980, a equipe multidisciplinar foi substituída pela figura do planejador, que assumiu uma visão global para sua função: de urbanista, técnico, comercial, financeiro e publicitário (CLAUDE, 2005).

Concomitantemente, diversos concursos foram realizados pelo EPA. Cada concurso compreendia três escalas de intervenções: 1) grandes concursos de urbanismo (arquitetura e organização urbana de áreas de 700 a 7 mil moradias); 2) concursos para habitação (mais recorrente, de 70 a algumas centenas de moradias); e 3) concursos de espaços públicos. Desses, seis concursos foram efetuados para o primeiro grupo, 32 concursos para o segundo grupo e 45 concursos para o terceiro grupo. Com isso, previa-se atribuir às CNs um caráter de novidade, 
associado a um caráter experimental - integração de funções urbanas e arquitetura de qualidade. Ao todo, 260 arquitetos ou agências trabalharam nos projetos, o que garantiu a cada CN uma diversidade arquitetônica (FRANCE, 1980).

Tal fato pode ser comprovado, atualmente, nas villes nouvelles, que se transformaram em roteiro turístico tanto para leigos como para profissionais da área, pelas “soluções espaciais miraculosas” adotadas (WERMES, 1991, p. 21, tradução nossa). ${ }^{8}$ Uma diversidade de arquitetura contemporânea, como: as “Arcadas do lago” de Ricardo Bofill (1939-); as escolas de Stanislaw Fiszer (1935-); as moradias de Alain Sarfati (1937-); o “Castelo d’água” de Christian de Portzamparc (1944-); e o eixo monumental do artista e escultor Dani Karavan (1930-) para Cergy-Pontoise.

De fato, as CNs francesas se tornaram um campo de trabalho para arquitetos-paisagistas assim como para recém-formados e outros profissionais (YOUNGMAN, 1998). Algo repetido não apenas na Europa como em outros continentes até os dias atuais.

No decorrer da história, vimos, portanto, o envolvimento de diferentes projetistas na criação de CNs. Foram filósofos, arquitetos, loteadores, planejadores, engenheiros militares, sanitaristas, civis, agrônomos, técnicos agrimensores, topógrafos, planejadores e artistas. Um leque de denominações distintas para definir o mesmo profissional: o urbanista.

Especialista em conceber o espaço urbano, em planejar as cidades, ele é o responsável por distribuir sobre "um solo vasto e parcimonioso as funções múltiplas” de uma cidade (DELOUVRIER apud TILLIETTE, 1985, p. 13, tradução nossa). ${ }^{9}$ Seja ela espontânea ou intencionalmente criada, toda cidade irá ter, em determinado momento, a contribuição desse profissional no gerenciamento de seu espaço físico a fim de qualificá-lo para seus habitantes.

Nas CNs, a participação de um urbanista é visível desde sua concepção. Após a decisão do empreendedor em criar uma urbe para um fim específico, tendo

"[...] solutions spatiales miraculeuses [...]"

9 "[...] un terrain vaste et parcimonieux aux multiples fonctions." 
condições propícias para sua construção, o urbanista entra em cena para tornar a cidade imaterial em cidade palpável. A partir do repertório, do conhecimento e da cultura que envolve essa personagem, a linha teórica seguida, o tipo adotado e o espaço urbano projetado tomam corpo sob a forma de uma cidade. Projetista e projeto ficam, assim, unidos na história de cada CN. 


$$
y
$$




\section{Cidades novas e o projeto}

Quinta parada: Goiânia (GO), Brasília (DF) e Palmas (TO).

Bem-vindos ao Planalto Central! Terra do cerrado, das chapadas, do tamanduá-bandeira, do pequi e dos buritis. Terra também de novas capitais - Goiânia (1933), Brasília (1957) e Palmas (1989) -, implantadas na hinterlândia para abrigar sedes de governos estaduais e nacional. CNs administrativas como marcos da ocupação territorial brasileira durante o século XX.

Se a "Marcha para o Oeste" teve início em São Paulo com a tomada de terras ermas em seu interior, a ele não se limitou. O processo de ocupação avançou pelas fronteiras paulistas rumo ao Mato Grosso, Paraná, Triângulo Mineiro até chegar a Goiás na década de 1940. Na busca pela ocupação e colonização do Centro-Norte do país, tal arrancada foi auxiliada por ações públicas, como a Expedição Roncador-Xingu e a Fundação Brasil Central, ambas da década de 1940; por projetos específicos, como as rodovias de integração nacional Belém-Brasília (década de 1950) e Transamazônica (década de 1960); e por programas desenvolvimentistas, como Prodoeste, Polocentro, Provale, Proterra, Polamazônia etc. (abordados na introdução do capítulo 6).

Foi um movimento demográfico direcionado por ações públicas e marcado pela abertura de fronteiras agrícolas, pela exploração de recursos minerais e pela fundação de dezenas de CNs. Políticas materializadas em três grandes episódios, ao considerarmos a história do urbanismo nacional: as fundações de Goiânia em 1933, de Brasília em 1960 e de Palmas em 1990. CNs que preconizaram "o desenvolvimento do Planalto Central sob o símbolo do Estado Moderno da Marcha para o Oeste” (MORAES, 2003, p. 90).

CNs administrativas em destaque na literatura especializada (livros, teses, revistas e Anais), principalmente Brasília, sendo objetos de interesse de pesquisadores, 
estudiosos e críticos nacionais e estrangeiros. Reflexões elaboradas com maior ou menor grau de detalhamento e enfoques diferenciados, que nos auxiliam a ter uma compreensão acerca dos três exemplares. Nesta obra, particularmente Goiânia, Brasília e Palmas foram reunidas por apresentarem mínimos denominadores comuns: empreendedores públicos engajados, função administrativa como dominante, sítios estrategicamente escolhidos, arquitetos como seus idealizadores formais e, especialmente, projetos que marcaram época ao refletirem os ideais urbanísticos em voga.

A Goiânia de Pedro Ludovico Teixeira (1891-1979), a Brasília de Juscelino Kubitschek de Oliveira (1902-1976) e a Palmas de José Wilson Siqueira Campos (1928-) revelam personalidades públicas engajadas e decisivas para as respectivas concretizações. Embora todas tenham sido sonhadas muito antes de sua fundação, foi durante a gestão desses governantes que se tornaram realidade. Goiânia foi fruto de uma luta liderada por Pedro Ludovico pela modernização de Goiás frente à tradição de uma oligarquia agrária sediada na histórica cidade de Vila Boa de Goyaz, sua antiga capital (MACIEL, 1996). Brasília foi uma das ações do Plano de Metas de Kubitschek enquanto presidente da República (1956-1961), concluindo um processo de mudança da capital nacional iniciado no período pombalino (século XVIII). E Palmas foi criada após a emancipação do estado de Tocantins - requerida desde 1821 por movimentos separatistas (CERQUEIRA, 1998) -, sendo firmada pelas mãos do então deputado federal Siqueira Campos e oficializada com a promulgação da última Constituição Federal em 1988.

Três cidades criadas para um propósito único: abrigarem a nova sede governamental de unidades federativas e da Nação após transferência de suas antigas bases, Goiás e Rio de Janeiro, ou pela necessidade de uma nova capital para um estado recém-criado, Tocantins. Função dominante rebatida no plano urbanístico das CNs pela presença de praças ao redor das quais os edifícios administrativos e judiciários foram alocados, como a Praça Cívica em Goiânia, a Praça dos Três Poderes em Brasília e a Praça dos Girassóis em Palmas - artifício utilizado igualmente 
em outras capitais projetadas, como: Washington (Mall), Belo Horizonte (Praça da Liberdade) e Canberra (Praça do Parlamento).

O desenho do traçado urbano foi elaborado de forma a qualificar essas praças como o espaço monumental de cada cidade. Os edifícios públicos receberam cuidados arquitetônicos especiais em relação às demais construções, espelhando os estilos da época: art déco em Goiânia, modernista em Brasília, pós-moderno em Palmas. Esplanadas que se tornaram um espaço cívico de destaque no conjunto da urbe, ponto focal de um ou mais eixos viários, lócus revelador da função original (sede do poder) para qual cada CN foi criada.

Desejo e necessidade evidenciados, o processo prosseguiu com a escolha de sítios propícios e estrategicamente localizados. A área de Goiânia foi escolhida após estudos feitos por uma comissão composta por engenheiros e médicos, que delimitaram quatro possíveis áreas, todas próximas à ferrovia, com disponibilidade de reservas aquíferas e presença de clima e topografia adequados, sendo selecionada aquela vizinha ao povoado de Campinas. Brasília, igualmente, teve seu sítio escolhido por uma comissão, a Missão Cruls (1892-1894), que delimitou um quadrilátero no centro geográfico do território brasileiro. No caso brasiliense, a posse do terreno foi simbolicamente marcada pela cruz desenhada por Lucio Costa ao traçar os dois eixos perpendiculares do Plano Piloto. O mesmo método do quadrilátero foi adotado na localização de um sítio para implantação de Palmas, com uma área de 90 por 90 quilômetros sobre a centralidade geográfica do novo estado. A partir dele, duas áreas ao sul, às margens do rio Tocantins e próximas à BR-153, foram selecionadas, cabendo a decisão final ao governador Siqueira Campos (CERQUEIRA, 1998).

Quanto aos projetistas, as três novas capitais contaram com a participação de arquitetos no comando dos planos das CNs: Attilio Corrêa Lima em Goiânia, Lucio Costa em Brasília e o escritório de arquitetura GrupoQuatro em Palmas. 
Cidades novas

Figura 14: Brasília

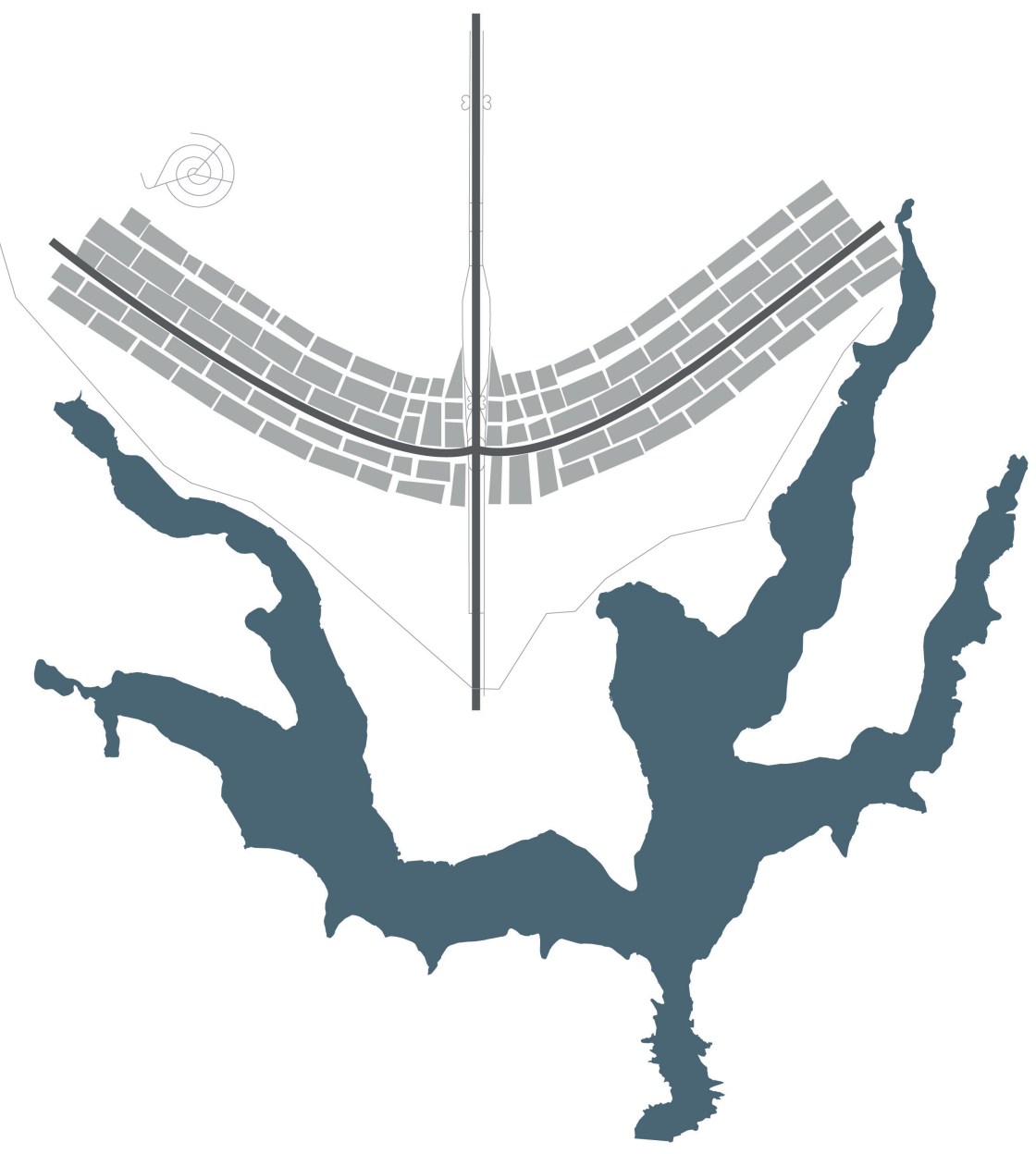


Em Goiânia, o arquiteto ítalo-brasileiro Attilio Corrêa Lima (1901-1943), graduado em arquitetura pela Escola Nacional de Belas Artes do Rio de Janeiro e em urbanismo pelo Institut d’Urbanisme de Paris, foi encarregado pelo interventor Pedro Ludovico para cuidar do projeto urbanístico da capital. Para auxiliar os trabalhos de implantação da CN, contratou-se o engenheiro civil Armando Augusto de Godoy (1876-1944), natural de Minas Gerais e formado pela Escola Politécnica do Rio de Janeiro (MANSO, 2001). Ambos apresentavam conhecimento sobre as teorias urbanas modernistas formuladas por Le Corbusier e sobre os conceitos de cidade-jardim e suas variantes, como a estabelecida por Clarence Stein (1882-1975) e Henry Wright (1878-1936) na unidade de vizinhança de Radburn, nos EUA (1929), tipologias que foram contextualizadas e aplicadas na nova capital de Goiás.

Em Brasília, o papel de projetista ficou a cargo do arquiteto Lucio Marçal Ferreira Ribeiro Lima Costa (1902-1998), ${ }^{1}$ natural de Toulon, na França, e formado pela Escola Nacional de Belas Artes do Rio de Janeiro. Um dos protagonistas da Arquitetura Moderna brasileira, Lucio Costa já havia projetado, em 1934, o plano urbanístico de uma CN, a cidade empresarial de Monlevade (MG). No ano de 1957, após concurso realizado pela Companhia Urbanizadora da Nova Capital (Novacap), que reuniu os principais arquitetos e urbanistas da época (TAVARES, 2014), o estudo preliminar de Costa foi selecionado em primeiro lugar.

Em Palmas, a responsabilidade em desenhar a nova capital tocantinense foi dada ao escritório de arquitetura GrupoQuatro, de Goiânia. Sob o comando dos arquitetos Luis Fernando Cruvinel Teixeira (1943-) e Walfredo Antunes de Oliveira (1948-), "graduados em escolas modernistas de Arquitetura e com pós-graduação em Planejamento Urbano e Regional em universidades inglesas” (CERQUEIRA, 1998, p. 85), a equipe de projetistas foi amparada por visitas técnicas às villes nouvelles francesas (PETIT, 2002). Apesar de todo o know-how apresentado pelos técnicos,

1 Embora se tenha conhecimento de cinco projetos elaborados entre os anos 1920 e 1940, por diversos profissionais, dentre eles: o historiador Theodoro Figueira de Almeida (plano de 1929), a engenheira Carmen Velasco Portinho (plano de 1936) e o deputado federal Jales Machado (plano de 1948). Todos planos marcados pela diversidade de formulações e interpretações (TAVARES, 2014). 
grande parte das decisões do GrupoQuatro foram limitadas ao serem submetidas à aprovação do governador Siqueira Campos (MORAES, 2003).

Assim, as CNs administrativas do cerrado foram favorecidas por fatores e condicionantes que corroboraram o surgimento de planos-referência no urbanismo brasileiro. Tais cidades foram, concomitantemente, campo de experimentação para teorias e técnicas contemporâneas e retrato de ideologias de um determinado período.

Geralmente, a interação entre os projetos propostos para as CNs no século XX e os conceitos inerentes às correntes urbanísticas - cidade monumental, cidade-jardim, modernismo, higienismo etc. - dava-se da seguinte forma: ou os profissionais incorporavam grande parte dos princípios pré-estabelecidos, adequando-os ao contexto nacional; ou eles os utilizavam de forma superficial, como fachadismo, em que apenas alguns aspectos eram incorporados, geralmente características físico-espaciais, para garantir a associação do espaço criado ao nome do movimento. Também houve casos de sobreposição de teorias num mesmo projeto, articulando-se os conceitos de acordo com as necessidades requeridas pelo partido projetual, com as características de um movimento sempre se sobressaindo em relação aos demais. Esse hibridismo urbanístico pode ser verificado, por exemplo, nos projetos das três capitais aqui expostas.

A proposta inicial para Goiânia, de Attilio Corrêa Lima, trouxe para o plano da nova capital as bases do urbanismo barroco, seus espaços cênicos e monumentais referência aos planos de Versalhes, Karlsruhe, Washington, Paris e Belo Horizonte. Por sua vez, aspectos modernistas foram empregados pelo arquiteto e urbanista ao setorizar a cidade por diferentes funções (trabalho, habitação, circulação e lazer) sobre um traçado rígido de vias regulares e delimitada por um cinturão verde de parques que protegeriam os aquíferos presentes na região, à la cidade-jardim. Para o setor comercial, delimitado pelas diagonais simétricas que saem da Praça Cívica e uma avenida semicircular (Avenida Parnaíba), o arquiteto projetou quadras permeadas por vias de serviço. Próximo ao plano, além da estação ferroviária - principal meio de transporte da época -, Corrêa Lima implantou o aeroporto, demonstrando estar atento às modernidades de sua época. 
Com a saída de Corrêa Lima do comando do projeto em 1936, após desentendimento com a firma empreendedora da obra (Coimbra Bueno \& Cia. Ltda.), o plano foi assumido e, em parte, reformulado pelo engenheiro Armando Augusto de Godoy. As modificações introduzidas tinham por base os conceitos de unidade de vizinhança - captados do tipo de urbanismo norte-americano - nas zonas residenciais (Setor Sul), em que a ideia de superquadras se fez presente pela primeira vez no país. Além disso, Godoy atribuiu um cuidado maior ao cinturão verde, que limitaria o crescimento da cidade previsto para 50 mil habitantes, e propôs inúmeras rotatórias em cruzamentos de vias principais - elemento que se tornou uma constante na expansão física da urbe.

O Plano Piloto para Brasília, do arquiteto Lucio Costa, previsto para 500 mil habitantes, foi concebido a partir da união entre o urbanismo racionalista, pautado por técnicas rodoviaristas, e o urbanismo Beaux-Arts, presente na composição simétrica e monumental do eixo administrativo (LEME, 1999). União materializada a partir do cruzamento de dois eixos cardo-decumano, onde Costa aplicou princípios do urbanismo modernista debatidos nos CIAMs (Congressos Internacionais de Arquitetura Moderna, entre 1928 e 1956) e descrito n’A Carta de Atenas de Le Corbusier (1933). Ao separar as principais funções da cidade, Costa ofereceu à nova capital diferentes dimensões, conhecidas por: "monumental” (eixo Leste-Oeste), “gregária” (cruzamento dos dois eixos), “bucólica” (orla do lago Paranoá, parques e espaços verdes que permeiam as superquadras) e "residencial” (eixo Norte-Sul).

Além do desenho racional e funcional modernista, permeado por elementos da cidade monumental, Sylvia Ficher e Pedro Paulo Palazzo (2005) detectaram outros paradigmas urbanísticos incorporados ao plano de Brasília: a especialização de vias, cuja intenção era favorecer o fluxo rápido de veículos (vias sem cruzamento direto) e separar as diferentes modalidades (pedestres e veículos); a expansão controlada da cidade por meio da criação de cidades-satélites; a proporção entre extensão e largura da ocupação prevista nos eixos, que gerou um plano linear aos moldes da cidade-modelo de Soria y Mata; a sociabilização do pavimento térreo nas áreas 
residenciais, refletindo os ideais howardianos da cidade-jardim; os princípios das unidades de vizinhança de Stein e Wright agenciando as superquadras; o adensamento à ville radieuse de Corbusier, com suas barras isoladas em amplos jardins; enfim, um conjunto de soluções urbanísticas articuladas simultaneamente sobre o mesmo espaço, para configurar um projeto sem precedentes na história das CNs e base de referência para aquelas que vieram após 1960, como Palmas.

A capital do Tocantins surgiu há 30 anos com uma proposta inovadora: ser a capital ambiental do século XXI (MORAES, 2003). Para isso, o GrupoQuatro buscou o mínimo impacto ambiental com a implantação do plano sobre o sítio selecionado, uma adequação do traçado aos recursos naturais presentes, tirando partido desses para criar uma cidade ecologicamente correta. Ademais, em depoimento dos urbanistas a Hugo Segawa, Palmas foi planejada como:

[...] uma cidade agradável para se morar e trabalhar, com uma estrutura viável do ponto de vista ambiental, econômico e social que permitisse a seus habitantes, em todas as classes sociais, acesso à moradia e ao trabalho. (SEGAWA, 1991, p. 96).

A partir dessas condições idealizadas, os projetistas se basearam em conceitos urbanísticos presentes nas capitais antecessoras - Goiânia e Brasília - para organizar espacialmente a CN, prevista para abrigar 1,2 milhões de habitantes.

Em vez da “cidade para o automóvel”, como Brasília, Palmas seria a cidade para o pedestre. A escala a ser priorizada na nova capital seria a do pedestre, particularmente trabalhada no interior de superquadras de 700 por 700 metros cada e nos dois centros comerciais. A outra escala seria mais dinâmica, presente nas avenidas, no centro cívico e nos parques lineares.

Além desse princípio, a malha regular cardo-decumano - repousada sobre uma área contida entre a Serra do Lajeado e o então futuro lago a ser formado na bacia do rio Tocantins - deveria atender a outros objetivos, dentre eles: estabelecer fácil 
e contínua conexão entre os corredores viários e os espaços públicos; propiciar articulação entre os espaços públicos e privados, cívico e comercial; garantir a expansão ordenada do solo urbano; introduzir técnicas bioclimáticas no desenho urbano de modo a garantir um microclima satisfatório; realizar estudos de impacto e viabilidade econômica com a construção da cidade; favorecer a acessibilidade às áreas de lazer, como a orla do lago; e incentivar a diversidade de usos do solo urbano, evitando as especializações como do tipo modernista. ${ }^{2}$

Assim, a última CN administrativa do Brasil surgiu, refletindo todo um conhecimento técnico obtido ao longo do século XX a partir das experiências urbanísticas colocadas em prática. CN que aguarda a passagem do tempo para se tornar uma cidade consolidada, seja aos moldes do projetado por seus arquitetos-urbanistas, seja deformada pelos interesses especulativos ou pela ausência de um governo regulador.

No caso específico das CNs capitais, longe de serem mero conjunto de moradias e infraestruturas, elas foram a manifestação física de certa ideia de vida urbana,

[...] a expressão de um estilo de vida que altos funcionários e homens políticos pretende[ra]m trazer. Dotadas de moradias e equipamentos de alta qualidade, com grandes subvenções públicas, elas devem servir de exemplo para outros projetos de planejamento e de urbanismo. (LELOUP, 1983, p. 36).

De todo modo, podemos perceber, a partir desses três exemplares brevemente descritos, a presença de um projeto urbanístico. O desenhar a totalidade de uma cidade para atender a uma determinada função, como sediar uma capital, traz para nós o quinto gene do DNA das CNs. Para ser uma CN é imprescindível a presença de um projeto, do mais básico (traçado de vias e quadras) ao mais complexo (traçado, setorização, edificações, normas etc.).

2 Informações obtidas no sítio eletrônico do escritório GrupoQuatro: <https://fernandoteixeira.arq.br/>. Acesso em: 21 fev. 2018. 
Um projeto realizado cujo resultado é o desenho do conjunto urbano, a "unidade de plano” descrita por Albert Levy (1992, p. 16, tradução nossa), ${ }^{3}$ em que o complexo de ruas, de lotes e de edifícios se combina e estabelece uma medida de homogeneidade morfológica (uma unidade). Ao longo do tempo, essa totalidade se materializa formalmente segundo as necessidades e as condições de cada $\mathrm{CN}$, conforme exposto na sequência do livro.

\subsection{Do planejamento ao projeto}

CNs são planejadas, CNs são projetadas. Antes de adentrarmos nas variações formais existentes nos planos urbanísticos das CNs, quero salientar que todas foram, em sua origem, objetos de planejamento, tendo por resultado um projeto.

Da ideia do(s) empreendedor(es) ao desenho urbanístico realizado pelo(s) projetista(s), a CN passou por um processo de planejamento - uma etapa de preparação na qual estavam inclusos aspectos referentes à função dominante, à escolha do sítio, à viabilidade econômica, às projeções demográficas etc. É um período gestacional - precedente ao nascimento da CN - no qual ocorre a determinação de um conjunto de ações visando à projetação do espaço físico. A partir desse planejamento, surgem planos (conjuntos de medidas de ordem política, social, econômica etc. que objetivam determinado resultado) e, posteriormente, o projeto (desenhos, cálculos, descrições, orçamentos etc., necessários para a realização da obra). Nesse sentido, assumo a definição de Jorge Wilheim (1969, p. 104) para essas variações processuais:

O projeto corresponde ao “design” e isto é a definição de todos aqueles pormenores que determinarão as estruturas ou a forma propriamente dita e sua produção, enquanto o plano corresponde à definição das condições gerais que devem pré-existir ao projeto e lhe servem de

\footnotetext{
3 “Unité de plan.”
} 
base. [...] O plano urbano está para o desenho das cidades na mesma relação do estudo preliminar arquitetônico para o projeto definitivo.

Já planejamento, para o urbanista, é a transformação da realidade urbana. Deve ser feito a partir da separação entre a análise de suas estruturas (aspectos estáticos) e a análise dos sistemas de vida (aspectos dinâmicos).

Porém, destaco que, no caso das CNs, o planejamento é realizado antes de sua existência, a partir do momento no qual foram idealizadas. Daí se seguem: o planejamento territorial para a escolha do melhor sítio; a montagem de um programa de necessidades com base na função dominante e nas condições essenciais para o funcionamento da urbe; a previsão da população almejada para dimensionamento da CN; a setorização funcional a fim de ordenar o espaço urbano; além de outras medidas. Um caminho de estudos, projeções e proposições percorridos até chegar à etapa do projeto, nascido num "contexto bem determinado e, de fato, espacialmente delimitado” (BOYER, 1983, p. 333, tradução nossa). ${ }^{4}$

Assim, planejamento, como definem Françoise Choay e Pierre Merlin (2005, p. 667, tradução nossa), ${ }^{5}$ é a "ação para fixar, sobre um determinado território, os objetivos de desenvolvimento e localização harmoniosa dos homens, suas atividades, equipamentos e meios de comunicação". Ações presentes em inúmeros exemplos ao redor do planeta, desde a Antiguidade até o presente.

Na Inglaterra do pós-Segunda Guerra Mundial, duas gerações de CNs marcaram diferentes ações de planejamento do governo inglês. A construção da primeira geração de new towns, aquelas situadas ao redor de Londres, foi precedida pelo surgimento de um grande número de estudos efetuados por profissionais de diferentes disciplinas assim como por um longo debate entre opinião pública e instituições políticas (AHTIK, 1969). Esse processo gerou o famoso relatório Reith e o New

4 "[...] contexte bien défini et, en fait, délimité dans l'espace."

5 "Action visant à fixer, pour territoire donné, les objectifs de développement et de localisation harmonieuse des hommes, de leurs activités, des équipements et des moyens de communication." 
Town Act, a Lei de 1946. Os dois documentos continham os princípios da concepção de CNs. Dentre esses princípios, cito: os esforços consagrados à implantação de atividades econômicas, sobretudo da indústria e de equipamentos coletivos; a barreira de crescimento materializado pelo cinturão verde; o tamanho limitado ao máximo de 60 mil habitantes, visando a criar e a preservar uma atmosfera social; e a concepção urbana, um tipo geral que define desde o início os objetivos e os meios de realização. Por sua vez, a segunda geração, aquela das expanded towns (cidades de expansão), destaca uma mudança completa de escala e de concepção. As cidades foram implantadas sobre um tecido urbano pré-existente, seu tamanho previa abrigar até 400 mil habitantes e sua vocação deveria ser regional.

Na França, o "plano mestre” (termo dado a planejamento) foi regido pelo Institut d'Aménagement et d'Urbanisme de la Région Parisienne (IAURP), responsável pela concepção e criação de novas cidades. Fundado em 1960, o IAURP lançou, cinco anos mais tarde, o Esquema Diretor de Planejamento e de Urbanismo da Região de Paris (Schéma directeur d'aménagement et d'urbanisme de la région de Paris - SDAURP), no qual constava um esboço de crescimento direcionado da Grande Paris sobre dois eixos, onde seriam "implantadas inicialmente oito grandes CNs, distantes no máximo 35 quilômetros da capital, sem qualquer cinturão verde” (DUMSDAY, 1984, p. 304, tradução nossa). ${ }^{6}$

Em Israel, a necessidade de abrigar imigrantes provenientes de todas as partes levou o governo a elaborar um planejamento de ocupação territorial por meio da criação de CNs - 30 CNs surgiram no país entre 1948 e 1963. Nesse planejamento, partiu-se por criar uma hierarquia de pequenos e médios núcleos que teriam relação direta com a zona agrícola. Foram essas médias cidades que permitiram a interlocução entre os centros urbanos mais importantes e os pequenos assentamentos rurais (EFRAT, 1994). A hierarquia dos novos assentamentos consistia em cinco níveis: tipo A (vilas com 500 habitantes); tipo B (vilas centrais, com aproximadamente 2 mil

6 “[...] initially deployed eight large new towns, distant at most 35 kilometers from the capital, without any greenbelt." 
habitantes); tipo C (centros semiurbanos de 6 a 12 mil habitantes); tipo D (cidades de médio porte de 40 a 60 mil habitantes); e tipo E (grandes cidades com 100 mil ou mais habitantes). A vila central deveria fornecer serviços a cinco vilas menores ao seu redor. O centro semiurbano deveria oferecer serviços mais sofisticados para 30 vilas, num raio de 10 quilômetros. A cidade de médio porte deveria concentrar instituições governamentais, bancos, hospitais e fábricas. A cidade grande deveria receber o status de capital regional e manter conexões com as demais importantes cidades do país. Os planejadores fizeram um grande esforço para estabelecer assentamentos dos tipos $\mathrm{B}, \mathrm{C}$ e $\mathrm{D}$ devido à capacidade destes de absorver novos imigrantes.

Na Holanda, o planejamento de CNs satélites ocorreu na década de 1950 como processo de urbanização do território, em especial da região oeste. Basicamente, previa-se manter o coração verde da Holanda aberto; promover a urbanização por meio de cidades novas a uma distância de 5 a 60 quilômetros de um núcleo urbano existente (BERG, 1989). Reunidos em quatro relatórios de ações e medidas a partir de 1958, esse planejamento abrangia, na etapa inicial (os dois primeiros relatórios), a Randstad Urban Area (região metropolitana entre Amsterdã e Roterdã); o terceiro concentrava sua atenção em áreas metropolitanas que perderam população e fontes de emprego devido à criação das primeiras CNs; e o quarto foi influenciado pelas mudanças sociais e pela "Europa sem fronteiras” (União Europeia).

Na URSS, os órgãos responsáveis pela criação de novos núcleos estabeleceram um planejamento próprio para direcionar seus projetos, baseando-o em métodos e técnicas modernos para resolver problemas urbanos e arquitetônicos. Assim, surgiram 60\% dos assentamentos urbanos após a Revolução de 1917 (UNITED STATES OF AMERICA, 1981). Desses, destacam-se dois tipos de CNs: aquelas planejadas para ocupar o território e aquelas para controlar a expansão de grandes cidades.

Entre 1930 e 1980, quando a população soviética passou de 20 milhões para 130 milhões, o governo realizou um milhar de novas cidades, a maior parte em terras desabitadas, com ações que alteraram, inclusive, o microclima (Sibéria), possibilitando sua ocupação pelo homem (MAMOLI; TREBBI, 1988). Exemplo 
é a CN de Kruscev (1954), para a qual a tentativa de migração programada em longo prazo, pautada pela criação de uma base econômica (agroindustrial) e de moradias e serviços, se fez presente.

Já o segundo tipo surgiu ao redor da capital Moscou, a partir de um anel perimetral receptor de 30 cidades-sputnik - definição oficial soviética para cidades-satélites -, ou ao redor da então Leningrado. ${ }^{7}$ Distribuídas entre 20 a 60 quilômetros do centro da cidade-mãe, essas cidades nasceram com uma especialidade particular - cidade do tecido, cidade metalúrgica, cidade eletrônica, cidade do turismo (MAMOLI; TREBBI, 1988).

A partir dos anos 1950, a URSS inicia um processo de exportar seu modo de urbanizar para todos os países por ela dominados - Europa Oriental. Tal doutrina foi reunida numa "carta-mandamento com 16 princípios de urbanismo”, que pregava um conceito de cidade tradicional (cidade compacta), alternado com visões modernistas de tabula rasa, setorização e padronização arquitetônica (BERNHARDT, 2005b).

De modo geral, as cidades-satélites apresentam características de planejamento semelhantes. Consolidaram-se após a Segunda Guerra Mundial, buscando reduzir o congestionamento - residencial, industrial, circulação - em grandes cidades, como Londres, Paris, Amsterdã, Moscou etc. Para a instituição inglesa Survey New Towns, as CNs dos países desenvolvidos, em especial aquelas de controle de expansão urbana, são um:

[...] compreensível projeto planejado onde o desenvolvimento é coordenado por uma organização estratégica. Quando completado, o projeto resulta na criação de uma substancial nova área de desen-

\footnotetext{
No entorno de Moscou, encontramos: Zelenograd (10 mil habitantes), Krioukovo (20 mil habitantes), Kaliningrad (100 mil habitantes), Podolsk (100 mil habitantes), Pouchkino (100 mil habitantes), Ramienskoje (100 mil habitantes), Noginsk (100 mil habitantes) e Elektrostal (100 mil habitantes). Ao redor de São Petersburgo (antiga Leningrado), temos: Kirovsk (10 mil habitantes), Krasnoesselo (20 mil habitantes), Petchosnaia (30 mil habitantes), Nevska-Dovbrovski (60 mil habitantes) e Kolpina (100 mil habitantes).
} 
volvimento urbano. Quando completado, o local urbanizado conterá a maioria de facilidades para sua população e que não dependa de outros serviços de cidades vizinhas, em outras palavras, que tenha comércio, escola e facilidades de recreação. (apud POTTER, 1987, p. 289, tradução nossa). ${ }^{8}$

O mesmo programa de autossuficiência foi adotado por países em desenvolvimento a fim de qualificar o planejamento urbano adotado para suas CNs. Na Malásia, elas foram planejadas para serem autônomas, com seus moradores trabalhando nos largos campos ao redor da nova cidade, provida de atividades e serviços necessários para a vida cotidiana (SALLEH; CHOGUILL, 1992). Fato também verificável na região de Ketengah e suas seis CNs: Bukit Besi, Al Muktafi Billah Shah, Ketengah Jaya, Seri Bandi, Ceneh Baharu e Cerul, implantadas entre os anos 1970 e 1980.

A partir do planejamento, programas são estabelecidos para viabilizar e qualificar as CNs. Especificamente sobre o programa das villes nouvelles francesas, identificaram-se dados precisos na organização espacial dos núcleos:

O centro da cidade nova deve ser o nível superior da hierarquia funcional e espacial. Ele é importante e densamente ocupado, com serviços atrativos, o ponto nodal da rede de transportes da nova aglomeração e a principal plataforma de transportes para sair da cidade. Os bairros constituem o nível médio, a maioria destinada à habitação, agrupando milhares de moradias, com equipamentos

8 “[...] understandable planned design where development is coordinated by a strategic organization. When completed, the design results in the creation of a substantial new area of urban development. When completed, the urbanized site will contain the majority of facilities for its population and will not depend on other services of neighboring cities, in other words, that it has commerce, school and recreation facilities." 
e meios de transportes que dariam acesso ao centro. (HAUMONT, 1997b, p. 35, tradução nossa). ${ }^{9}$

Além disso, recomendou-se a constituição de unidades populacionais de tamanho reduzido (pequenos bairros, conjuntos habitacionais ou unidades de vizinhança), dotadas de boas moradias, equipadas e próximas ao emprego.

No Japão, a programação de CNs repousa sobre algumas bases simples. Os sítios escolhidos em função de considerações fundiárias são todos irregulares, por vezes dividindo o plano em partes diferentes e mesmo separando-o (MERLIN, 1976). A maior parte das $\mathrm{CNs}^{10}$ é composta por unidades de vizinhança, cada qual com seu próprio centro comercial e colégio. Majoritariamente, as moradias são habitações coletivas, agrupadas no setor central. As moradias individuais ficam na periferia, todas permeadas por espaços verdes.

No caso de CNs com funções empresariais, o programa se restringe: à preferência por assentamentos de pouca relevância e dimensões; à necessidade de áreas para locação industrial; à realização de formas de concentração de serviços; e à acessibilidade fácil aos recursos naturais e ambientais (MAMOLI; TREBBI, 1988). Para esse tipo de assentamento urbanístico, portanto, uma planificação integrada é indispensável para a formação de um tecido conectivo entre zonas produtivas e o restante da cidade (residencial, comercial, serviços).

9 "Le centre de ville nouvelle devrait être au niveau supérieur de la hiérarchie fonctionnelle et spatiale. Il est important et densément occupé, avec des services attrayants, le point nodal du réseau de transport de la nouvelle agglomération et la principale plateforme de transport pour sortir de la ville. Les quartiers constituent le niveau intermédiaire, la plupart d'entre eux étant destinés au logement, regroupant des milliers de logements, dotés d'équipements et de moyens de transport leur permettant d'accéder au centre."

10 Algumas CNs japonesas, construídas entre 1958 e 1968: Tama (400 mil habitantes, próxima a Tóquio), Senboku (190 mil habitantes, próxima a Osaka), Senri (150 mil habitantes, próxima a Osaka), Kosoji (100 mil habitantes, a 20 quilômetros de Nagoya), Suma (100 mil habitantes, a 10 quilômetros de Kobe); Lakusai (40 mil habitantes, a 10 quilômetros de Kioto); e Isamaya (18 mil habitantes, a 18 quilômetros de Nagasaki). 
Ademais, Melville C. Branch (1983, p. 147-148, tradução nossa) ${ }^{11}$ sintetizou, a partir da análise de diversos planos para CNs, os elementos típicos na constituição de seus espaços:

[...] o tamanho da cidade determinado pelo número de habitantes; a designação da densidade populacional por zonas urbanas; a locação de zonas de atividades conforme normas preestabelecidas; a presença de comércio, serviços e equipamentos culturais e de lazer para atender a população; a presença de células residenciais; a delimitação do centro da cidade com sede do governo local; a existência de extensiva área verde após o limite urbano (cinturão verde); a preservação do cenário e adequação do plano ao ambiente preexistente; a arquitetura e a engenharia compatíveis com as diferentes áreas; a incorporação de arte urbana em espaços públicos (esculturas, estátuas, murais etc.); a proximidade a um conjunto de rodovias, ferrovias e a recursos naturais; uma hierarquia viária contendo um conjunto de vias principais e um secundário claramente demarcados; a separação entre vias de veículos e vias de pedestres; a setorização para áreas industriais; um zoneamento vertical em determinadas áreas.

11 “[...] the size of the city determined by the number of inhabitants; the designation of population density by urban areas; the hiring of activities zones according to pre-established norms; the presence of trade, services and cultural and leisure facilities to serve the population; the presence of residential cells; the delimitation of the city center with hall of the local government; the existence of extensive green area after the urban boundary (greenbelt); the preservation of the scenario and the adequacy of the plan to the pre-existing environment; the architecture and engineering compatible with the different areas; the incorporation of urban art into public spaces (sculptures, statues, murals, etc.); the proximity to a set of highways, railroads and natural resources; a road hierarchy containing a set of clearly marked primary and secondary roads; the separation of vehicle lanes and pedestrian sidewalks; the sectorization for industrial areas; zoning in certain areas." 
Características intrínsecas aos programas das CNs do século XX, das quais seleciono: a relação dimensão versus número populacional, o zoneamento e a especialização de vias para uma exposição mais detalhada.

Certo que uma CN dificilmente é uma entidade estática - pois seu tamanho só será fixo se sua população for controlada por normas estritas: seu dimensionamento original é planejado a partir da previsão populacional que irá receber. Os projetistas partem do número de habitantes, obtido a partir de estudos e necessidades realizados durante o planejamento gestacional, para dimensionar o espaço da futura cidade. Números que vão de modestos 2 mil a 30 mil habitantes, como as CNs empresariais brasileiras e a CN administrativa de Halfa El-Gedida (Sudão), construída para 30 mil habitantes (DOXIADIS et al., 1973), mas que podem chegar a números expressivos, como a CN de Ali Mendjeli, uma cidade-satélite ao redor de Constantine (Argélia), criada nos anos 1990 para 300 mil habitantes alojados em 50 mil alojamentos (BOUMAZA, 2006); como as villes nouvelles do entorno parisiense, projetadas para uma população de 200 mil a 300 mil habitantes (BLEYNIE, 1977); e como a CN chinesa de Yi Zhuang, próxima a Pequim, prevista para 200 mil habitantes.

A quantidade populacional é muitas vezes superada, como em Goiânia (previsão de 50 mil habitantes), que hoje conta com mais de um milhão de moradores, e Cumbernauld (previsão de 50 mil habitantes), na Escócia, redesenhada quatro anos após sua fundação (1956) devido às 70 mil pessoas que ali já habitavam. Inversamente, episódios de CNs que não atingiram a população esperada também existem, como: Águas de São Pedro, visionada para 10 mil habitantes nos anos 1930, e que hoje conta com apenas 2,5 mil moradores; e o Plano Piloto de Brasília, que, às vésperas de completar 50 anos, não se aproximou da meta inicial de 500 mil habitantes - talvez porque não haja projeções para abrigá-los.

Outro ponto comum às CNs é a adoção de um zoneamento de funções a fim de ordenar o espaço urbano. A organização intraurbana, desde muito, é recorrente, sendo explorada por Vitrúvio na Antiguidade, posteriormente normatizada nas 
Leyes de las Indias e nas “Cartas Régias” - ordenanças dos governos espanhol e português, respectivamente, que continham as diretrizes para a organização das cidades criadas no Novo Mundo -, ou, ainda mais detalhada, após a Revolução Industrial, quando a cidade se tornou sede das principais atividades econômicas. Para Pier Luigi Giordano (1962, p. 237, tradução nossa), ${ }^{12}$ esse foi o momento no qual as CNs foram "trabalhadas por um zoning distributivo (ordenar a vida do citadino), da cidade industrial de Garnier à soviética de Miliukin, da cidade linear de Soria-y-Mata à racionalista de Le Corbusier, da cidade em altura de Hilbersheimer à cidade em extensão de F.L. Wright”. Normas e regras de uso, de ocupação e de crescimento, geralmente elaboradas pelo profissional idealizador do projeto.

As CNs do século XX eram, antes de tudo, consideradas um complexo "trabalho-repouso-vida cotidiana” (MERLIN, 1992, p. 8, tradução nossa) ou um conjunto de quatro funções básicas: trabalho, moradia, circulação e lazer (LE CORBUSIER, 1933), setorização ou zoneamento funcional adequado a cada tipo de CNs, como nas cidades empresariais soviéticas.

Por último, temos a especialização das vias: ruas, avenidas, bulevares, que ganham funções e atributos nas CNs muito além da simples meta de promover a circulação no espaço consolidado. Tomemos as CNs administrativas e suas avenidas monumentais como exemplo. O tridente, ou patte-d'oie, se tornou um artifício fundamental para projetistas conseguirem uma imagem cênica dos edifícios públicos. Essa tentativa de controlar uma porção do território a partir de alguns monumentos alinhados por eixos que deles partem foi, como já dito, utilizada nas principais reformas urbanas de capitais europeias, em CNs administrativas mundo afora (incluindo Brasil) e, inusitadamente, em pequenas CNs de colonização do interior do estado do Paraná. Nessas localidades, tal recurso foi amplamente utilizado como elemento destoante da malha homogênea empregada, posicionado à frente de edifícios importantes, prioritariamente a estação ferroviária (BARNABÉ, 1995).

12 “[... opera di una zonizzazione distributiva (ordinando la vita della città), dalla città industriale di Garnier al Soviet di Miliukin, dalla città lineare di Soria-y-Mata al razionalista di Le Corbusier, dalla città di Hilbersheimer alla città in estensione di F. L.Wright.” 
Paralelamente, o surgimento e a disseminação de veículos automotores pelas cidades acarretaram numa nova organização. Primeiro, no sentido de ordenar o fluxo de veículos a partir de uma hierarquia viária (vias arteriais, coletoras e locais), dando origem a ruas especiais, como os culs-de-sac (ruas residenciais sem saída) de Raymond Unwin (1909). Segundo, as vias para veículos e as vias para pedestres foram separadas a fim de garantir maior segurança, como o fizeram Frederick Law Olmsted e Calvert Vaux no Central Park de Nova York (1853); Stein e Wright na unidade de vizinhança de Radburn (1929); e o arquiteto norueguês Hans Hartvig Skaarup na CN de Heimdal (1966).

O mesmo ocorreu na CN polonesa de Nowe Tychy, concebida pelo governo em 1953 e prevista para 120 mil habitantes, cujo projeto foi baseado em duas composições axiais. Uma, do Leste para o Oeste, era centralizada por uma linha férrea, interrompida por inúmeras pontes que permitiam a passagem de vias que ligavam a parte norte à parte sul. A outra, de Norte a Sul, era composta por um corredor verde apenas para pedestres, ligando o parque do norte com equipamentos de lazer localizados ao sul: escola de música, cinema, teatro e salas de exposições (WAWRZYNSKI, 1986).

Assim, ficam aqui alguns indícios projetuais, elementos compositivos do projeto global, que permitem afirmar que as CNs são fruto de um planejamento, moldado num programa específico de necessidades e cristalizado em projetos urbanísticos elaborados por profissionais sob diferentes formas. Formas distinguidas no presente livro entre traçado (aspecto bidimensional das CNs: vias e quadras) e tecido (aspecto tridimensional das CNs: traçado e edificações).

\subsection{Cidades novas e suas formas}

Primeiro, o homem é semelhante ao jogador que, quando se senta à mesa, toma na mão cartas que não inventou, pois o jogo de cartas é um dado da história e da civilização. Em segundo lugar, cada 
repetição das cartas resulta de uma distribuição contingente entre os jogadores e se faz sem que eles percebam. Há mãos aceitas passivamente, mas que cada sociedade, assim como cada jogador, interpreta nos termos de vários sistemas, que podem ser comuns ou particulares: regras de um jogo ou regras de uma tática. E se sabe muito bem que com a mesma mão jogadores diferentes não farão a mesma partida, se bem que não possam, coagidos também pelas regras, jogar qualquer partida com qualquer mão.

(LÉVI-STRAUSS, 1962, p. 111-112)

A diversidade com a qual nos deparamos ao observar os diferentes projetos urbanísticos para as CNs permite-me fazer um paralelo ao cenário descrito por Claude Lévi-Strauss. Os projetistas (jogadores), quando incumbidos de projetar uma cidade (jogo), vão buscar, em sua época e em épocas anteriores, repertório (cartas) para desenhar os espaços urbanos. Referências agenciadas de acordo com a habilidade do autor, as necessidades previstas e as circunstâncias locais. Ao fim da partida, temos cidades únicas, cada qual com sua própria identidade, obtida, dentre outros aspectos, pela forma dada ao seu traçado (estrutura urbana bidimensional) ou ao seu tecido (estrutura urbana tridimensional).

A morfologia urbana, ou estudo da forma urbana, das CNs possibilita-nos ter consciência sobre a riqueza desse tipo urbanístico. Para Claude Chaline (1985, p. 8, tradução nossa), ${ }^{13}$ ao contrário das incoerências e espontaneidades do traçado de uma cidade de crescimento natural, a CN é “o triunfo da ordem: a ordenança do espaço, mesmo contendo em seu traçado uma aparência irregular”. Para José Osvaldo de Meira Penna (1958, p. 12), a CN é fruto da "ação consciente do homem que procura dispor, em formas e espaços racionalmente concebidos, os objetos do estabelecimento

13 “[...] un triomphe de l'ordre: ordennancement de l'espace, même jusque dans son apparente informalité $[\ldots]$ ” 
coletivo no solo”. Já Frédérique Boucher-Hedenström (2005, p. 148, tradução nossa) ${ }^{14}$ determina que cada $\mathrm{CN}$ “tem um modelo único e é produto de sua época”.

Formas urbanas ordenadoras, racionalmente concebidas e espelhos de uma cultura destacam as CNs como campo de práticas e pesquisas urbanísticas. Ao analisar grandes períodos históricos de uma cidade, podemos perceber a formação ou a transformação do traçado e do tecido urbano, isto é, de suas vias, de seus parcelamentos e de suas edificações. No caso das CNs, essa análise é peculiar, pois temos o entendimento da morfologia global da urbe num recorte preciso de espaço e tempo. O conjunto urbano pode ser apreendido no momento de sua fundação, um retrato relativamente fiel daquilo inicialmente imaginado por seu(s) projetista(s), salvo aspectos arquitetônicos não contemplados no plano original.

Sabemos que os traçados urbanos das primeiras CNs na Antiguidade, de tipo essencialmente ortogonal, estavam carregados de significados religiosos e metafísicos (cidade grega, etrusca, romana etc.). A variedade formal era extremamente limitada, seguindo, por vezes, o comando de um ritual sagrado, dados astronômicos e limitações técnicas (KOSTOF, 1999). Foi necessário esperar o Renascimento e os avanços tecnológicos para nos depararmos com o segundo grande tipo de traçado: o radioconcêntrico, como em Sforzinda, a cidade ideal de Filarete, e suas derivações - o tridente e outras figuras conhecidas da composição urbana. Nessa mesma época, o conteúdo religioso dos traçados urbanos cedeu espaço para a estética, a política e o simbólico. Em paralelo, a ortogonalidade continuou a ser utilizada, porém com outras atribuições. No plano para a Barcelona de Cerdà, por exemplo, o traçado ortogonal foi aplicado a fim de garantir uma igualdade absoluta - social e de condições de higiene. A manzana quadriculada não apresentava diferenças de lotes e possibilitaria a todas as edificações uma insolação idêntica (LEVY, 1992).

As transformações da forma urbana prosseguem e, na Paris haussmanniana do século XIX, “o crescimento urbano perde sua característica centralizada para se tornar aracnídea, pela introdução das ferrovias e das indústrias no espaço urbanizado” 14 “[...] modèle et produit de votre temps $>$ " 
(BENSAID; LE JEANNIC, 1989, p. 14, tradução nossa). ${ }^{15}$ Assim, a supremacia das cidades reais e das cidades-mercados passa às cidades industriais, com suas contrarrespostas formais idealizadas por inúmeros profissionais.

São teorias que, no entreguerras (1919-1938), levam o traçado urbano a não satisfazer somente as condições estéticas, como para a arte urbana clássica, mas também as condições técnicas funcionais, higiênicas etc., próprias às exigências da época moderna, assim defendido pelos progressistas dos CIAMs - ainda que alguns urbanistas desse período, membros da Société Française des Urbanistes, reivindicassem a ideia de uma arte urbana possível.

Após a Segunda Guerra Mundial, a forma urbana será marcada por um zoneamento sistemático e pela forte consumação do espaço. Nesse momento, as CNs apresentam:

[...] modelos de urbanismos variados, revelando concepções opostas: cidades anglo-saxônicas são vendidas, fazendo promoção da casa individual; as cidades do leste europeu são mais compactas, com blocos maciços; as cidades francesas associam um centro - constituído de imóveis funcionais e residenciais - com bairros periféricos justapondo conjuntos coletivos e lotes individuais. (BLOC-DURAFFOUR, 1998, p. 89, tradução nossa). ${ }^{16}$

Face à urbanização proliferativa e anárquica, certos arquitetos-urbanistas representantes do Team X - procuraram introduzir em CNs a ordem e controlar a expansão urbana pela forma da trama técnica (trama racional hexagonal, ortogonal ou triangular) ou pela forma de megaestruturas.

15 “[...] la croissance urbaine perd son caractéristique coconeux pour devenir arachnide, par l'introduction des chemins de fer et des industries dans l'espace urbanisé.”

16 “[...] des modèles d'urbanismes variés, révélant des conceptions opposées: les villes anglo-saxonnes sont vendues, favorisant la maison individuelle; les villes d'Europe orientale sont plus compactes, avec des blocs massifs; les villes françaises associent un centre - constitué d'immobilier fonctionnel et résidentiel - à des quartiers périphériques juxtaposant des ensembles collectifs et des lots individuels.” 
Um panorama histórico resumido por Pierre Lavedan (1926) revela três grandes períodos: o urbanismo antigo, dominado pela religião; o urbanismo clássico, dito estético (incluindo o barroco); e o urbanismo presente, caracterizado, sobretudo, por ferramentas práticas, tais como higiene e circulação. Esse é um dos estudos mais completos de sua época, como afirma Albert Levy (1992), realizado a partir de uma aproximação morfológica da cidade pelos diferentes traçados desenhados ao longo do tempo. Tipos que nos auxiliam a estudar e a compreender a forma da cidade questão morfológica - pela problemática da configuração urbana (traçado e tecido), analisada por vários estudiosos ao tentar buscar um sentido próprio à forma urbana.

Para o arquiteto inglês Ivor Samuels (apud CHOAY; MERLIN, 1986), ela pode ser definida como produto tridimensional dos processos de desenvolvimento urbano guiados pela prática, explícita ou implícita, do desenho urbano. Ainda para ele, a forma urbana envolve a ação não somente de arquitetos e urbanistas, mas também de investidores e de coletividades.

Por sua vez, Albert Levy (1992), ao analisar a cidade, separa-a em dois elementos: o receptáculo (a substância física da cidade) e o conteúdo (a substância social), sendo o primeiro a linguagem espacial pela qual o conteúdo se manifesta. Para o autor, o receptáculo - forma urbana - apresenta três níveis de aproximação: 1) a forma urbana como dispositivo topológico: a distribuição urbana que cristaliza um modelo ideológico de cidade; 2) a forma urbana como configuração geométrica: a conformação urbana (eixos, traçados, tramas, figuras etc., que regularizam e sustentam a implantação urbana); e 3) a forma urbana como expressão física: o tecido urbano. Segundo Françoise Choay e Pierre Merlin (1986, v. 1, p. 26, tradução nossa), ${ }^{17}$ nesses "três níveis estão, de fato, todas as expressões físicas, mesmo que a primeira se refira a modelos ideológicos”.

Essa classificação é parecida à realizada pelo fundador da escola anglo-germânica de morfologia urbana Michael Robert Günter Conzen (apud LEVY, 1992), que

17 “[...] ces trois niveaux concernente en fait tous l'expression physique, même si le premier se réfère à des modèles idéologiques.” 
estabeleceu um método de análise urbana baseado em três sistemas complexos de formas: o plano, o tecido construído e a estrutura de utilização do solo. O primeiro é constituído pelo sistema viário, o sistema de parcelamento formado por lotes e o sistema criado pela impressão dada por edifícios existentes. O segundo é composto por tipos construtivos, funcionais e históricos, em que cada um possui seu plano particular, sua elevação e seu estilo arquitetônico próprio. O terceiro é fundado sobre os usos dos edifícios, o qual se define pelos conjuntos funcionais no interior da cidade. Do ponto de vista dinâmico, as formas urbanas são solidárias de "processos generalizados subjacentes”, de natureza econômica e social, ligadas a culturas distintas chamadas períodos morfológicos e, respectivamente, caracterizadas por um conjunto único de formações urbanas. A originalidade do olhar de Conzen “reside essencialmente na delicadeza de sua análise, que é capaz de representar adequadamente diferentes fases de crescimento morfológico e, por consequência, de definir a forma atual de nossas cidades” (LEVY, 1992, p. 16, tradução nossa). ${ }^{18}$

Ao compartilhar dos mesmos princípios no presente livro, saliento que a análise da forma urbana das CNs será feita somente pela identificação do traçado e do tecido, particularmente por ser o projeto apenas um dos focos de interesse na conceituação desse tipo urbanístico. Um estudo, elaborado de modo despretensioso para confirmar a existência de um projeto urbanístico - seja ele bidimensional ou tridimensional - na composição conceitual das CNs.

Para isso, busco, em sequência, reunir, num flash, projetos de inúmeras CNs implantadas em diversos países, divididas em dois campos de apreensão: seu traçado ou seu tecido. A partir das variantes levantadas e classificadas segundo uma visão particular, cria-se um mosaico das diferentes formas que compõem os projetos, demonstrando a relevância e a pertinência desse tipo urbanístico para estudos morfológicos futuros.

18 “[...] réside essentiellement dans la finesse de son analyse qui est capable de représenter adéquatement différentes phases de la croissance morphologique, et par conséquent de définir laforme actuelle de nos villes [...]" 
Traçado: cidades novas em 2D

As CNs em duas dimensões, ou as CNs e seus traçados, referem-se à estrutura urbana composta pelo desenho da trama viária, responsável pela delimitação de vias, quadras e lotes no espaço das cidades; é a "grelha” exposta historicamente por Spiro Kostof em seu livro The city shaped, de 1999. Trata-se da parte bidimensional de uma cidade, uma vez que desconsidera as edificações - "a terceira dimensão”, segundo PANERAI (2006).

Nem todas as CNs foram projetadas em seu conjunto - traçado e arquitetura -, ficando a construção dos edifícios a cargo dos futuros moradores, a exemplo do ocorrido nas CNs de colonização do oeste paulista e norte paranaense. Fator que não as desqualifica conceitualmente. Para serem CNs, elas devem apresentar ao menos um traçado integralmente formulado e construído para o estágio pós-natal - após sua fundação -, elaborado a partir de previsões feitas durante seu planejamento. Esse traçado varia seguindo as épocas de realização e as doutrinas assimiladas por seus projetistas. Nesse sentido, inúmeros pesquisadores, ao longo do século passado, se especializaram em estudar e conceituar os diferentes tipos existentes.

O arquiteto-urbanista inglês Raymond Unwin já discutia em sua obra literária Town planning in practice, de 1909, a introdução à arte de traçar os planos de melhoramentos, organização e de extensão. Para o autor, dois grandes tipos de traçados existiam: os “regulares” e os "irregulares” (ou pitorescos), trabalhados por duas grandes escolas de composição urbana: a escola clássica e a escola neogótica - originárias da arte de jardinagem: regular ou geométrico e irregular ou pitoresco.

Em 1933, o urbanista francês René Danger publica sua obra Cours d'urbanisme, na qual apresentou a seguinte classificação de traçados urbanos: 
1. “Traçado topográfico”, aquele onde as vias seguem as linhas topográficas, como: linhas de cume, de talvegue, paralelas e perpendiculares às curvas de nível;

2. “Traçado radioconcêntrico”, aquele onde as vias afetam a disposição de circuitos concêntricos em relação ao ponto principal interior, de onde partem vias radiais rumo ao exterior e efetuando ligações de diversos circuitos. Duas categorias são consideradas: a “natural”, cujo traçado é condicionado pela topografia; e a “convencional”, cujo traçado é guiado pela preocupação em facilitar a circulação;

3. “Traçado ortogonal”, aquele mais comum, apropriado por fórmulas diversas, como: cruciforme, quadrilátero, retangulares, paralelas, e com diagonais;

4. “Concepções arquitetônicas”, aquele traçado geométrico estabelecido por uma vontade de conjunto, onde a ordem do desenho e das perspectivas apresentam uma pesquisa e uma vontade de simetria, atendendo a composições de arquitetura, como Versalhes (“concepções arquitetônicas regulares”); ou aquele traçado que aparenta formas do jardim inglês (“concepções arquitetônicas paisagísticas”).

Além dessa distinção, o estudioso francês detectou, nesse período, as diferentes escolas de composição de traçados urbanos segundo as sensibilidades nacionais:

1. “Escola inglesa”: caracterizada por sua vontade de constituir a cidadejardim;

2. “Escola alemã”: marcada pela presença de duas figuras importantes: Camillo Sitte (1843-1903) e Joseph Stübben (1845-1936), que realizaram estudos minuciosos do urbanismo medieval, colocando em evidência um número importante de regras de perspectiva urbana; 
3. "Escola americana”: impulsionada pela eclosão das "cidades-cogumelos", dirigidas pelo dogmatismo e pela estandardização de ideias. Cidades construídas em séries, segundo o autor, como as colônias romanas quadriculadas, tendo algumas diagonais, um zoneamento preciso, uma regularidade na distribuição dos edifícios públicos e um sistema de parques como diretrizes projetuais;

4. “Escola francesa”: um equilíbrio entre as tendências inglesa e alemã, com atuação de profissionais - Marcel Auburtin (1872-1926), Henri Prost (18741959), Léon Jaussely (1875-1932), Alfred Agache (1875-1959), Jacques Gréber (1882-1962), entre outros - em lugares diversos - Marrocos, Reims, Barcelona, Filadélfia e Rio de Janeiro.

Na mesma época, seu conterrâneo Jean Raymond, no livro Précis d'urbanisme moderne (1934), explorava o conceito de traçado da cidade com uma distinção simplificada entre a "tendência americana retilínea” e a "tendência latina curvilínea”. A partir dessa dualidade, cinco tipos de traçados foram elencados: "traçado em xadrez", "traçado em losango” (traçado xadrez com inserção de diagonais), "traçado radioconcêntrico", "traçado concêntrico sem vias radiais” e "traçado linear”.

Recentemente, encontramos conceituações e classificações semelhantes. Para o professor de urbanismo Albert Levy, em La qualité de la forme urbaine, de 1992, o conceito de traçado urbano é "preciso e limitado", com duas definições possíveis. Uma “definição tradicional e clássica”, onde o traçado é representado frequentemente sob a forma de grelha ou malha, compreendendo seja o desenho dos espaços livres (via, praça, cruzamento etc.), seja os eixos organizadores. E uma “definição mais ampla e mais recente”, que engloba todos os tipos de traçados possíveis (viário, parcelar, construído). Com relação à taxonomia do traçado, o professor francês estipula cinco tipos diferentes: o "traçado ortogonal”, o "traçado radioconcêntrico" - ao qual devem se unir os outros tipos de sistemas geométricos -, o "traçado flexível” (irregular), o "traçado linear” (como a cidade linear de 
Soria y Mata e as cidades desurbanistas soviéticas), e o "traçado emblemático ou simbólico” (de Brasília e demais capitais projetadas).

Por sua vez, o arquiteto-urbanista Philippe Panerai aborda o tema em seu livro Analyse urbaine, de 1999 (Análise Urbana, 2006), no qual diagnostica os seguintes tipos de traçado: "radioconcêntrico" (cidade densa e compacta), “modernista” (cidade da ordem e do controle), “estirado” (ao longo de vias), “em malha” (cidade regular) e “difuso” (crescimento da cidade).

Já autores como Dieter Prinz (1980) e Pedro Paulino Guimarães (2004) definem variações no traçado pela simples configuração da trama viária, separando-a em: “radial”, "reticular (com inclusão de diagonais)” e “em anéis” (PRINZ, 1980); e “radial”, “radial concêntrica”, “ortogonal” e “linear” (GUIMARÃES, 2004).

Além da apreensão do traçado pelo aspecto preciso do desenho urbano, certos autores seguiram uma classificação por meio de olhares diferenciados, seja pela sociologia (Christopher Alexander) ou pela economia (Juan Luis Mascaró).

O arquiteto-matemático Christopher Alexander sistematizou em seu artigo A city is not a tree, de 1965, a estrutura urbana em duas possibilidades: a "cidade em árvore” e a “cidade em semitreliça”, atentando para questões sociais. A “cidade em semitreliça” (cidades espontâneas) representa uma estrutura potencialmente mais complexa e mais sutil que uma árvore. A variedade enorme de traçados sobrepostos num sistema em semitreliça é um índice da complexidade estrutural factível. Para o autor, “uma cidade viva é e deve ser uma estrutura em semi-treliça, pois possibilita criar uma rede de interações sociais” (ALEXANDER, 1967, p. 7, tradução nossa). ${ }^{19}$ Já a “cidade em árvore” (cidades artificiais) exclui a possibilidade de conjuntos que se sobrepõem, formada geralmente por estruturas urbanas contíguas, que adotam a unidade de vizinhança, seu zoneamento e setorização. Uma simplicidade estrutural na qual fica explícito o desejo de colocar tudo em ordem, de modo simétrico e hierárquico. Assim, uma cidade

19 “[...] une cité vivante est, et doit être, une structure semi-treillis, car elle permet de créer un réseau d'interactions sociales.” 


\section{Cidades novas}

com estrutura em árvore não responde adequadamente às necessidades sociais, como as relações de amizade (ALEXANDER, 1967).

Por outro viés, o arquiteto-urbanista Juan Luis Mascaró, no manual Loteamentos urbanos, de 2003, assume a divisão entre "malhas fechadas" e "malhas abertas e semiabertas", tratando o traçado urbano sob o ponto de vista econômico. Conforme afirma, a viabilidade do empreendimento está diretamente relacionada ao tipo de traçado adotado. A “malha urbana fechada ortogonal”, a "malha urbana não ortogonal” (losango) e a "malha urbana triangular" (malha ortogonal com diagonais) favorecem uma construção com baixo custo de infraestruturas e lotes melhor distribuídos em oposição às cidades com "malhas irregulares”. $\mathrm{O}$ autor ainda constata que malhas abertas, como "espinha de peixe”, "com ruas sem saída em T", "traçado aberto e ruas em alça”, apresentam problemas estruturais, desqualificando-as frente às "malhas fechadas".

Portanto, a diversidade de tipos e escolas de traçado urbano é notória e consolidada: tipos compartilhados por profissionais da área, assumindo denominações diferenciadas para um mesmo objeto e recebendo novas nomenclaturas conforme a transformação das cidades e de suas necessidades. Traçados urbanos, que, nas CNs, foram utilizados ou isoladamente (Belo Horizonte, Andradina, Nova York, Barcelona) ou combinatoriamente (Brasília, Serra do Navio, Goiânia), de acordo com a vontade de seu(s) empreendedor(es) e o conhecimento de seu(s) projetista(s).

Neste livro, inicio a classificação do traçado urbano das CNs por um parâmetro delimitador. A partir da fixação ou determinação dos limites de extensão da malha, diferencio as CNs em dois grupos: as CNs fechadas e as CNs abertas, independentemente do tipo de traçado urbano nelas inserido. Esses dois grupos representam o modo como as cidades foram projetadas em sua origem, tendo o conjunto da composição urbana o engessamento ou não de seu crescimento.

O primeiro grupo, das CNs fechadas, está relacionado à limitação da composição urbana e de sua população por elementos definidos por seu(s) projetista(s). Tais recursos envolvem dispositivos obtidos da natureza ou construídos pelo homem, implantados no limite entre a zona urbana e a zona rural. Uma divisão clara que 
define o começo ou fim da CN, delineada pelo cinturão verde das new towns inglesas; pelo canal fluvial da CN de Stolen (1426) na Holanda; ou pelos sítios escarpados das bastides francesas. Mesma separação conseguida pela fortificação, como na CN de Avola (1757) na Itália; pelo delineamento de uma via perimetral, como em Belo Horizonte e sua Avenida do Contorno; ou pela própria estrutura urbana fechada, como na CN de Ilha Solteira (1967), em São Paulo.

O segundo grupo, das CNs abertas, diz respeito a traçados elaborados para um crescimento contínuo e homogêneo, previsto pelo(s) autor(es) do projeto, conforme o desenvolvimento da cidade. Nesse caso, malhas regulares, lineares e modulares favorecem o processo de expansão do traçado, exemplificados, respectivamente, pelo espraiamento igualitário da cidade do México, pelo plano da CN de Angélica (1956) e pelo esquema modular da CN de Juína (1977), ambas no Centro-Oeste.

Dessa divisão preliminar, direciono nossa atenção para a análise dos tipos de traçado urbano encontrados nos exemplares de CNs durante a pesquisa. Com base nos estudos classificatórios existentes, parti para uma divisão própria dentre as diferentes grelhas detectadas, chegando a sete possibilidades: 1) traçado em malha; 2) traçado em linha; 3) traçado ramificado; 4) traçado em módulo; 5) traçado radioconcêntrico e circular; 6) traçado irregular; e 7) traçado híbrido.

O traçado em malha - originário no Egito e na China há milhares de anos, como forma de drenar e irrigar terras por igual e criar rotas que levavam os produtos agrícolas até as cidades -, além de ser um dos mais antigos, foi o tipo mais aplicado ao longo da história das cidades, particularmente por ser facilmente executado, de resultados eficientes e o mais apropriado para uma rápida e efetiva ocupação e colonização de terras conquistadas. 
Figura 15: Ilha Solteira

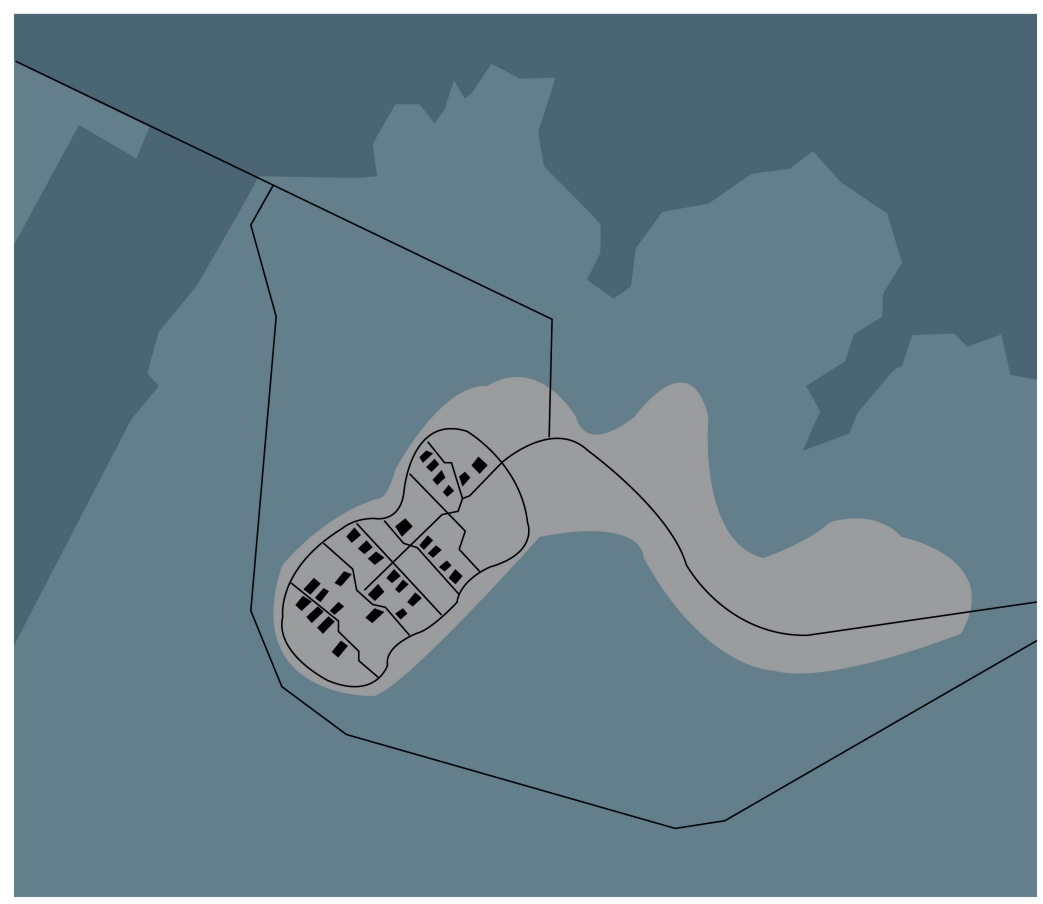

Na Antiguidade, o limitatio ou centuriatio era a operação pela qual os romanos traçavam uma grelha aberta sobre o conjunto de seu território, auxiliados pelos gromatici. ${ }^{20}$ A quadrícula de terras se estendia a partir de um sistema de coordenadas correspondentes aos eixos cardo-decumano, responsáveis, pelo menos em teoria, por um desenvolvimento ilimitado da trama (PANERAI et al., 1985). Tal organização espacial foi empregada, especialmente, em ações militares, visando à disciplina e à rigidez, como relata Philippe Panerai (2006, p. 19): "A geometria é sistematizada e transformada em instrumento de conquista [...] distante de Roma, um oficial subalterno pode rapidamente traçar e repartir terras para o cultivo ou lotes para habitação entre seus soldados."

${ }^{20}$ Gromatici é uma técnica de agrimensura permitida pela groma - instrumento utilizado pelos agrimensores romanos e que permite um traçado em ângulo reto -, utilizada para dividir o solo sobre uma concepção ortogonal e para organizar o desenvolvimento do território agrícola. Técnica transmitida ao longo dos séculos por documentos jurídicos, traduzidos nos monastérios na Alta Idade Média. 
Traçado ortogonal presente no castrum da CN de Timgad e nas demais cidades coloniais do Império Romano, como cenário favorecido em função das facilidades que essa malha permitia em adaptar-se a terrenos planos das regiões, pela rápida execução e pela possibilidade de futuras expansões urbanas mais coerentes - integração entre partes antiga e nova a partir de uma unidade morfológica.

São preceitos que avançaram pelo Medievo, sendo apropriados, em pequena escala, nos campos de cultivos e no parcelamento interno das bastides - núcleos urbanos regulares, cuja malha quadriculada comporta ao centro uma praça ladeada de arcadas. Também uma forma urbana recorrente no urbanismo renascentista e nas cidades de colonização na América, seguindo um plano centrado, com trama regular e a praça como figura.

Na América espanhola, a urgência de colonização e a amplidão dos territórios fizeram a técnica geométrica ser vastamente aplicada (CACCIAVILLANI, 2005). De modo geral, as cidades de traçado regular eram compostas por quarteirões de 100 a 120 metros de lado, quadradas e organizadas a partir de uma praça das armas, do comércio ou da administração e igreja, como nas CNs de Quito (1534), no Equador; Santiago (1541), no Chile; Guadalajara (1542), no México; Caracas (1567), na Venezuela; e Buenos Aires (1580), na Argentina.

Método igualmente explorado na ocupação territorial dos Estados Unidos da América. No livro Thomas Jefferson et le projet du Nouveau Monde (2007), a autora, Catherine Maumi, retrata todo o processo de divisão do país norte-americano pela quadrícula, seguindo ordenações e leis fortalecidas após a independência (1776) e asseguradas pelas políticas implementadas entre 1801 e 1809, no governo do presidente Thomas Jefferson (1743-1826). Conhecimento rebatido nos traçados urbanos de suas CNs, padronizadas por uma malha retangular salteada com praças intercaladas. Ordem e regularidade presentes nos projetos para: Nova Haven (1638), Filadélfia (1683), Savannah (1734), Nova York e Chicago no século XIX. Malhas por vezes sobrepostas, como em Washington D.C. (1791) e Jeffersonville (1802). Cidades fundadas com os serviços básicos de infraestrutura, “divulgados 


\section{Cidades novas}

às massas de imigrantes para que tomassem consciência de que não estavam indo para uma região primitiva de fronteira” (HAMER, 1994, p. 130, tradução nossa). ${ }^{21}$

No Brasil, tal traçado foi intensamente utilizado nas CNs desde o período pombalino, permeando as CNs de colonização da primeira metade do século XX, como Jales (1928) e Adamantina (1939), chegando às cidades-satélites do Distrito Federal, como o projeto para Taguatinga (1958) e Ceilândia (1971).

O traçado em linha, embora descendente direto do traçado em malha, apresenta uma característica peculiar que o destaca: seu comprimento é consideravelmente maior que sua largura. Trata-se de um tipo presente desde o período medieval na figura das sauvetés - vilas criadas ao longo de estradas, como Puentelarreina na Espanha e Nogaro, na França -, ou das terre nuove italianas - vilas com a presença de uma rua-mercado, criadas próximas às cidades existentes (PANERAI et al., 1985). Os planos retilíneos, assim como as demais malhas ortogonais, dispunham de uma praça pública e quarteirões retangulares, diferenciando-se por possuírem ruas principais extremamente longilíneas e ruas secundárias, as transversais, bem curtas, a exemplo do projeto para cidade de New Winchelsea (1292), na Inglaterra (DELAFONS, 1999).

Na modernidade, tal traçado foi teorizado pelo espanhol Arturo Soria y Mata (1844-1920) em 1882. O primeiro exemplar foi fundado em 1904, a Ciudad Lineal, pela Companía Madrileña de Urbanización. Construída nos arredores de Madri, ligava as vilas de Fuencarral e Pozuelo de Alarcón por uma ferrovia de 58 quilômetros de comprimento.

No século XX, surgem as roadtowns ou stradopoli, segundo Pier Luigi Giordano (1962). Le Corbusier (1887-1965), nas décadas de 1920 a 1940, assume o traçado linear nas propostas de megaestruturas, como no Edifício autoestrada para o Rio de Janeiro (1929) e no Plano Obus para Argel (1930), ou mesmo em CNs, como o projeto para Cidade Industrial Linear de 1942.

21 “[...] made known to the masses of immigrants aware that they were not going to a primitive border region." 
Em alguns casos, numa apreensão mais ampla da urbanização do território, podemos afirmar que um conjunto de CNs também conforma uma cidade linear, como as CNs ao longo das linhas férreas (interior de São Paulo e Paraná) ou de rodovias (Rodovia Belém-Brasília). Essa qualificação torna-se mais clara ao observarmos as cidades-satélites implantadas no percurso de trens suburbanos, como nas periferias de Estocolmo, Copenhague e Paris. A própria distribuição espacial da nova cidade ocorre de forma linear, seguindo a ferrovia, como percebido em visita às villes nouvelles de Cergy-Pontoise e Marne-la-Vallée.

Há, todavia, casos de CNs projetadas intencionalmente para serem lineares. Magnitogorsk, de 1930, na Rússia, e Paulínia (projeto), de 1969, em São Paulo, são exemplos de CNs traçadas linearmente, empreendidas pelo poder público a fim de atender funções industriais.

O traçado ramificado, também conhecido por “espinha de peixe”, é um tipo mais recente, cuja origem está embasada na especialização das vias, isto é, na hierarquia viária presente nas cidades modernas. O aumento de veículos no espaço intraurbano e respectivos estudos técnicos de trânsito corroboraram para uma diversificação e classificação de vias.

De largas avenidas arteriais, passando por vias coletoras até ruas mais calmas e residências, as principais tipologias viárias foram introduzidas nas cidades do século XX, especialmente pelo urbanismo funcionalista, sendo dimensionadas conforme a capacidade de fluxo e a função. Vale ressaltar, nesse tipo, a presença de uma trama pouco interativa, onde a permeabilidade pela malha é barrada por percursos que acabam em ruas locais sem saídas. Aspecto presente nas CNs de Alta Floresta, no Mato Grosso (1975), e Tucuruí (1979), no Pará.

O traçado em módulo surge simultaneamente ao traçado ramificado, influenciado diretamente pela teoria de unidade de vizinhança, como resposta aos problemas da cidade industrial e à forma de expansão urbana.

Em 1911, no projeto elaborado para o conjunto residencial de Forest Hills, em Nova York (EUA), o arquiteto-paisagista Frederick Law Olmsted incorporou, 
no setor habitacional, uma escola e um centro de comércio e serviços, propondo, dessa maneira, determinada autonomia para o setor em relação à cidade. Seguindo a mesma linha dessa proposta de unidade autônoma de Olmsted, o planejador Clarence Arthur Perry (1872-1944), no contexto do plano de Nova York de 1929, propõe, em uma monografia, o conceito de unidade de vizinhança, que ilustra com uma proposta genérica muito semelhante ao projeto de Forest Hills:

\begin{abstract}
A teoria de unidade de vizinhança se apoia no conceito sociológico de vizinhança que em seu entendimento clássico é uma área onde os habitantes se conhecem pessoalmente, têm hábito de se visitar, ou de trocar objetos, serviços e de fazer de vez em quando coisas em comum. (BARCELLOS, 2000, p. 3).
\end{abstract}

No mesmo ano, ocorreu a primeira aplicação dessa teoria no plano de Radburn, Nova Jersey, projetado pelo arquiteto-urbanista Clarence Samuel Stein (1882-1975) na companhia do arquiteto-paisagista Henry Wright (1878-1936). Radburn tornou-se um paradigma para a teoria do planejamento urbano, por reunir uma série de inovações não apenas sociais como de desenho urbano, ao incorporar: a superquadra; a hierarquização entre vias de passagem e vias locais por meio dos cul-de-sacs; a separação entre vias de veículos e de pedestres, visando ao conforto e à segurança, principalmente das crianças; e a criação de parques posteriores às residências.

O conceito de unidade de vizinhança foi amplamente difundido e aplicado nas cidades norte-americanas, sobretudo em zonas suburbanas e nas CNs. Na Europa e demais continentes, sua aplicação tomou fôlego após a Segunda Guerra Mundial, sendo incorporado em projetos de remodelação urbana e na criação de novos núcleos (cidades-satélites). Seu agenciamento em módulos, idênticos ou não, facilitava a organização socioespacial da futura cidade bem como o controle sobre seu desenvolvimento.

Foi assim com as new towns inglesas a partir de 1946, quando todas foram concebidas tendo a unidade de vizinhança como objeto-base de seu traçado - medida 
prevista inclusive no New Town Act. Neste, o planejamento dos módulos regulares deveria adequar-se à topografia natural do sítio e dispor de áreas verdes (quatro hectares para cada mil habitantes), de lotes amplos e de áreas de lazer para as crianças. O plano de Ongar (atual Harlow) serviu como tipo para as demais CNs inglesas (como Cwmbran, em 1949, Runcorn, em 1964, e Milton-Keynes, em 1967), para as quais se previram 60 mil habitantes vivendo em seis unidades de vizinhança autossuficientes, “definidas topograficamente, com edifícios no platô mais alto separados por cinturões verdes” (YOUNGMAN, 1998, p. 22, tradução nossa). ${ }^{22}$

Nos países nórdicos, Vällingby (1950), na Suécia, e Tapiola (1952), na Finlândia, destacam-se por apresentarem, em seus primeiros esboços, referências ao conceito de unidade de vizinhança. Em Vällingby, cidade-satélite de Estocolmo, prevista para 23 mil habitantes, cada módulo teria sua independência, com seu próprio centro em volta de uma estação de metrô, com comércio, serviços e equipamentos públicos essenciais, além de espaços verdes e equipamentos esportivos. A hierarquia viária foi conseguida pela diferenciação entre modos de circulação: rodovias, avenidas, ciclovia, ruas e calçadas (BOUCHER-HEDENSTRÖM, 2005). Já Tapiola, localizada a 10 quilômetros da capital Helsinque, surgiu a partir de um concurso para atender a 16 mil habitantes. Seu projeto foi subdividido em unidades de vizinhança, caracterizados pela homogeneidade nos gabaritos das edificações (três a quatro pavimentos), com destaque para apenas um edifício de maior altura (MAMOLI; TREBBI, 1988).

Configuração urbana similar à CN de Bokaro, na Índia, organizada em módulos (com 700 a 750 habitações cada), reunidos em setores (cinco módulos somados a escolas maiores e a equipamentos de maior porte), e, por fim, agrupados ao redor de um centro para toda a cidade. Além de Bokaro, as CNs indianas de Rourkela, Bhilai e Durgapur foram projetadas seguindo o mesmo sistema modular (KAMBO, 1971).

Cidades modulares propostas também para populações maiores, como em Poulad Shahr, no Irã, com previsão de 300 mil moradores na primeira etapa. O plano, elaborado pelo governo iraniano em parceria com profissionais russos, apresen-

22 “[...] defined topographically, with buildings on the highest plateau separated by greenbelts." 
tava nove distritos com 50 vizinhanças. Cada distrito teria entre 30 mil e 40 mil habitantes, com inúmeras vizinhanças e um serviço central composto por escolas, biblioteca, restaurantes, teatro, cinema, clínica médica, áreas de recreação e mesquita. Cada vizinhança teria entre 3 mil e 5 mil habitantes vivendo em mil casas geminadas (ATASH; BEHESHTIHA, 1998).

Solução adotada em CNs com outras funções dominantes, como a CN empresarial de Agbaja, na Nigéria - uma antiga vila de 1,5 mil habitantes, que, após a instalação de uma indústria (exploração de uma jazida de minério de ferro), obrigou autoridades e empresários nigerianos a projetarem sua expansão, visando a atender de 33 mil a 44 mil habitantes. O problema foi abordado por um estudo em "microcosmo: o homem e sua família”. A partir desse ponto, organizava-se a cidade em módulos: da casa ao grupo de casas, do grupo de casas à unidade de vizinhança, e da unidade de vizinhança à noção de colônia. Grupos de quatro a cinco moradias fariam um conjunto de habitações. A unidade de vizinhança seria composta por 11 conjuntos (52 moradias). Quatro unidades de vizinhança formariam uma colônia (208 moradias), que representava “uma população de 1600 a 1664 pessoas sobre um sítio de 13 hectares, cujo ponto central é[era] o mercado” (ARADEON, 1968, p. XXXVII, tradução nossa). ${ }^{23}$

Assim, uma pequena amostra do tipo de traçado urbano amplamente adotado na segunda metade do século XX, em CNs criadas mundo afora. Um traçado em célula, cujo interior contém desde tramas regulares a malhas irregulares - adaptação à topografia ou mera questão estilística -, hierarquizadas segundo as necessidades.

O traçado radioconcêntrico, que engloba o traçado circular, também pode ser considerado um dos mais antigos - presente em representações hieroglíficas no Egito dos faraós -, sendo, contudo, tipicamente europeu, conforme afirma Philippe Panerai (2006, p. 16). Uma forma espacial relacionada às questões político-econômico-tecnológicas de uma sociedade, atrelada "a uma representação centralizada do mundo e [...] do poder”, cujo centro reúne as instituições de comando (palácio,

23 “[...] une population de 1.600 à 1.664 personnes sur un site de 13 hectares, dont le point central est le Marché." 
prefeitura, igreja etc.), e mesmo atrelada a avanços de técnicas bélicas (advento do canhão). Do centro irradiam-se as principais vias de acesso à cidade, intercaladas por vias perimetrais até chegar à muralha. Esta, conforme o crescimento das cidades sobre seus arrabaldes, é substituída por outra mais distante, sendo a antiga derrubada, cedendo espaço a uma nova via perimetral.

Morfologia típica das cidades ideais e de ocupação territorial do Renascimento, apresentam dois principais aspectos: o contorno (podendo ser circular, quadrado ou poligonal) e a divisão interior do plano (radial ou espiral), como na CN italiana de Palmanova (1593), projetada pelo arquiteto Vicenzo Scamozzi.

Embora a visão e a apreensão de mundo não sejam mais as mesmas e as disputas militares disponham de outros estratagemas, tal tipo ainda se faz presente tanto em vilas operárias - veja-se a vila Jupiá, edificada em 1961 para receber mão de obra responsável por construir a hidrelétrica de Ilha Solteira -, como em projetos para CNs, seja a circular Viaike-Ismayac, na ex-URSS, seja Nahalal (1921), no atual território de Israel, seja a utópica CN de Spencer Edward Sanders (1906-2004) e Arthur Jacob Rabuck (ignoto), publicada no livro New city patterns: the analysis of and a technique for urban reintegration, de 1946.

O traçado irregular ou orgânico, também chamado de "traçado topográfico", deriva das Escolas Inglesa e Alemã de urbanismo - embora indícios dele há muito existissem, fosse em cidades fundadas intencionalmente, fosse naquelas de origem espontânea. Sitte, Howard e Unwin são alguns de seus defensores, teorizando em obras literárias.

A adequação do traçado ao sítio e à sua topografia é uma das premissas desse tipo, que igualmente considera a "relação constante com a natureza, por plantações, gramados, planos d'água e pela proximidade a bosques, campos e rios” (HAUMONT, 1997, p. 38, tradução nossa). ${ }^{24} \mathrm{O}$ traçado irregular não seria apenas “um recipiente dentro do qual se mete a população, mas o recipiente que se adapta democraticamente 24 “[...] relation constante avec la nature, par les plantations, les pelouses, les cascades et la proximité des bois, des champs et des rivières." 
à população”, como afirma Pier Luigi Giordano (1962, p. 184, tradução nossa). ${ }^{25}$ Assim, esse traçado é um dos mais contextuais, mostrando uma adequação, sempre que possível, às necessidades e a dados físico, social e cultural da futura cidade.

A propagação desse conceito de cidade e de traçado é creditada, principalmente, à cidade-jardim de Howard, repercutindo em exemplares de CNs inglesas, desde Letchworth até as new towns da primeira e segunda geração do pós-guerra - todas apresentando "uma proximidade ao campo, uma urbanidade e a reaproximação da classe média e operária” (SAFIER, 1977, p. 6, tradução nossa). ${ }^{26}$ Assim como ressoou por países da Europa continental e além-mar. Nos EUA, durante o New Deal, tomam-se como exemplos: Norris Dam (1934), no vale do Tennessee, e Greendale (1936), projetada pelo arquiteto-paisagista Albert Peets para 12 mil habitantes - CNs que revelam vias curvilíneas, grandes áreas verdes preservadas, equipamentos públicos, um cinturão verde para prática de atividades rurais etc.; CNs desenhadas por um traçado irregular que garante ao espaço urbano uma qualidade bucólica e pitoresca, típica de áreas rurais.

E, por fim, temos o traçado híbrido, ou o traçado que articula dois ou mais tipos dentre os mencionados. Esse traçado pode ser identificado, normalmente, em países de urbanização recente - países colonizados, como EUA, Brasil, Austrália e países do continente africano -, onde existiam: uma liberdade de experimentações, a ausência de escolas urbanísticas consolidadas e a flexibilidade presente em leis e normas para desenho da futura cidade.

A partir da combinação de traçados antes aplicados isoladamente, nascem cidades com uma espacialidade urbana diversificada, garantida pelo agenciamento do traçado em módulo com o traçado irregular, do traçado linear com o traçado modular, do traçado ramificado com o traçado radioconcêntrico, além de outras possibilidades. Como exemplo, relembro os traçados das novas capitais Goiânia e Brasília, expostos

"[...] un contenitore all'interno del quale entrare nella popolazione, ma il contenitore che si adatta democraticamente alla popolazione.”

26 “[...] la proximité a la campagne, l'urbanité et le rapprochement de la classe moyenne et ouvrière $[\ldots]$ " 
ao início deste capítulo, cujos projetistas incorporaram conceitos de diferentes teorias, traçados mesclados segundo as necessidades e o conhecimento profissional.

\section{Tecido: cidades novas em 3D}

Se o traçado é recorrente a todas as CNs, o tecido urbano se restringe a uma parcela delas. A “terceira dimensão” (PANERAI, 2006, p. 94), traduzida pela volumetria das edificações, foi incorporada aos projetos das CNs cujo grau de detalhamento se mostrou mais abrangente do que o daquelas que ficaram apenas no traçado: um grupo restrito de CNs projetadas tridimensionalmente, que tem por aspecto comum o "controle de sua arquitetura e da silhueta construída” (LLOYD, 1989, p. 304, tradução nossa). ${ }^{27}$

A procura por uma rápida instalação de futuros habitantes (CNs empresariais), o controle maior sobre a arquitetura e a paisagem do novo núcleo (CNs administrativas) ou o emprego de um novo modo de habitar a cidade (CNs de expansão urbana) foram alguns dos fatores que levaram projetistas, a pedido de empreendedores, a desenhar não somente o traçado como a propor sua composição volumétrica. Edificações públicas, centros comerciais e conjuntos habitacionais emolduraram e preencheram o espaço urbano dessas CNs, materializados segundo os estilos urbanísticos e arquitetônicos prevalecentes no período de suas fundações. Arquiteturas que permitem, como aponta Bernard Rouleau (1985, p. 146, tradução nossa), ${ }^{28}$ "seguir o processo histórico do conjunto dos aspectos morfológicos [...] presentes nas tramas viárias e nas parcelas urbanas”.

Tal qual o traçado, o tecido urbano recebeu definições de estudiosos e pesquisadores. Sob o ponto de vista estrutural, Albert Levy (1992) compõe o tecido pela parcela, pelo viário, pelo espaço construído e pelo espaço livre, aos quais acrescenta o sítio natural e seus constituintes morfológicos (relevo, curso d’água, vegetação). A partir desses elementos, ou "redes”, como os denominou, ocorrem

27 “[...] control of its architecture and built silhouette."

28 “[...] suivre le processus historique qui fait évoluer conjointement l'ensemble des facteurs morphologiques [...] a partir d'une appropriation précise du sol et de ses délimitations parcellaires. » 
as “interrelações sintáticas específicas entre as diversas redes”, entendidas como unidades morfológicas (LEVY, 1992, p. 18, tradução nossa). ${ }^{29}$

A mesma unicidade foi diagnosticada por Ivor Samuels (apud CHOAY; MERLIN, 1986) ao definir tecido como "plano unidade”, onde os complexos de ruas, de parcelas e de edificações estão em combinação individual em diferentes zonas da cidade, tendo cada combinação sua "unicidade de circunstâncias criadas pelo sítio e estabelecidas segundo uma medida de homogeneidade morfológica ou unidade, parcial ou global, sobre a zona” (WHITEHAND apud CHOAY; MERLIN, 1986, p. 28, tradução nossa). No caso de uma CN, essa unidade pode ser atribuída ao conjunto urbano (integralidade da cidade) ou aos diferentes setores (comercial, administrativo, residencial etc.), conforme as diretrizes projetuais adotadas.

Portanto, o tecido nas CNs não nasce do azar, como ressalta Pierre Merlin em Morphologie urbaine et parcelaire (1988). Para o francês, parcela, viário, espaço construído, espaço livre e sítio consistem em postular a existência de uma lógica na organização do tecido urbano - “uma morpho-lógica do tecido” (LEVY, 1992, p. 3, tradução nossa) -, ${ }^{30}$ obedecendo a leis próprias.

A presença de uma lógica na estruturação dos elementos teciduais possibilita a pesquisadores utilizá-los como instrumentos de análise urbana, como fez o professor Saverio Muratori (1910-1973), nos anos 1950, em seu ensaio Studi per uma operante storia urbana di Venezia (1960). Nele, o urbanista italiano baseia a análise de uma cidade no tipo de edifício e na tipologia de traçado que ela apresenta. Anos mais tarde, o francês Philippe Panerai, ao instituir sua concepção de tecido - conformado por vias, quadras, lotes e edificações -, delega à continuidade do espaço público o recurso para apreender o traçado e o tecido de uma cidade (PANERAI, 1988).

O arquiteto Gianfranco Caniggia (1933-1987), por sua vez, cria conceitos para estudo do tecido. Surge o "tipo de base” ou a “célula elementar" - de cinco a seis metros quadrados - que, por agregações sucessivas, dará “pseudotipos”, que, funcionalmente

29 “[...] interrelations syntaxiques spécifiques qui qualifient [...] tel ou tel type de tissu urbain [...]" 30 "[...] une morpho-logique du tissu [...]" 
diferenciados, darão lugar, por aglomerações entre eles, a um primeiro "tecido de base”, que, por extensão progressiva e hierarquizado por vias, dará os "tecidos particulares” (CANIGGIA; MALFROY, 1986). Ou seja, para Caniggia, o tecido urbano é resultado de um processo de formação progressiva, que se desenvolve por agregações sucessivas de elementos novos e por extensão gradual no espaço. Trata-se de uma lógica da gênese de formação e de transformação do tecido, postulando a existência de uma ordem subjacente regulando o seu crescimento (organicidade tecidual).

Para uma CN projetada em seu conjunto (traçado e arquitetura), o tecido urbano é concebido como um todo, num prazo de tempo relativamente curto, sobre um sítio previamente escolhido, sendo sua completude assegurada por leis e normas. A evolução do tecido, à qual se refere Muratori, Panerai e Caniggia, só é perceptível nos casos em que a arquitetura não foi globalmente contemplada ou quando as necessidades dos moradores se tornam maiores do que aquelas previstas pelos projetistas.

Nesta obra, o tecido urbano como instrumento de entendimento projetual das CNs será utilizado apenas pelo aspecto de composição volumétrica (conjunto das edificações). Do mesmo modo que diagnostiquei diferentes tipos de traçado, cabe agora revelar ao leitor os tipos de composição volumétrica que caracterizaram as CNs ao longo da história, isto é, uma pequena e breve amostra obtida a partir dos exemplares encontrados, passível de alteração (acréscimos) conforme a continuidade de estudos dessa tipologia urbanística.

Inicialmente, identifico e classifico o tecido de uma cidade de acordo com as tipologias formais das edificações existentes, variando entre: 1) tecido em pátio (blocos contínuos circundando uma quadra, gerando um pátio em seu interior); 2) tecido em rua (blocos contínuos ocupando todo o espaço de uma quadra retangular); 3) tecido espraiado (edifícios de pequeno porte isolados em lotes de generosa dimensão); 4) tecido sem lotes (barras retilíneas ou em redans e torres ocupando quadras sem loteamento definido - projeções); 5) tecido monumental (traçado e arquitetura conjuntamente projetados a fim de garantir um cenário apoteótico); e 6) tecido em megaestruturas (enormes edifícios multifuncionais, cuja localização 
organiza o traçado e se ramifica pelo espaço urbano). Dessas variações, uma diversidade de combinações se apresenta, desde agenciamentos uniformes e contínuos de um único tipo até agrupamento de dois ou mais.

Em períodos mais remotos, as CNs apresentavam uma composição volumétrica mais homogênea. Esse controle formal foi base do urbanismo renascentista e barroco e permeou planos de CNs, como o de Richilieu, um núcleo residencial fundado no século XVII (hoje, parte da cidade de Versalhes) com plano retangular de 682 por 487 metros. Nele, cidade e arquitetura foram pensadas simultaneamente, sendo projetadas em função de assegurar a simetria e a unidade das formas urbanas (PANERAI et al., 1985). Um modo de construir cidades que permeou as CNs de colonização americana, conformadas por edificações de um a dois pavimentos, implantados num tecido em pátio ou tecido em rua, com destaque para os edifícios de maior prestígio localizados ao redor de praças, como São José de Mossâmedes (1801) em Goiás. Mesmo em tempos modernos, CNs revelaram uma regularidade volumétrica na disposição de sua arquitetura, como Barcelona de Cerdà (1855) e seus blocos isolados de seis pavimentos se repetindo por centenas de manzanas.

Dispostos ortogonalmente no traçado em malha, esses exemplares se diferenciavam de outros que possuíam traçados curvilíneos, como em Bath, na Inglaterra. Originária de empreendimento privado, a cidade balneária foi pioneira em proporcionar urbanismo, equipamentos e sociabilidades especificamente para a função de lazer (banho e cura) - aqui colocada como tipo de tecido monumental. Projeto arquitetônico e urbanístico dos John Wood (pai e filho), entre 1726 e 1732, o plano centralizava tudo ao redor da praça Queen Square, quadrada e ladeada por edifícios com fachadas monumentais de seis tipos diferentes. Em 1754, a Royal Circus foi construída - uma praça circular de 100 metros de diâmetro fechada por três conjuntos idênticos de imóveis de três pavimentos. Entre 1767 e 1774, John Wood Filho projetou o royal crescent, um conjunto monumental disposto em colunas iônicas de fachadas sobre uma semielipse aberta para uma paisagem natural. 
Na virada do século XX, a teoria de cidade-jardim e, anos mais tarde, o conceito de unidade de vizinhança trouxeram a baixa densidade para zonas residenciais das CNs, onde casas isoladas ou geminadas eram implantadas sobre lotes envoltos pela natureza (tecido espraiado), como visto na primeira garden-city inglesa: Letchworth (1903). Artifício apropriado e adaptado pelos arquitetos dos CIAMs, porém com um forte adensamento pontual, seja pela presença de edifícios verticalizados (a cidade em altura de Hilbersheimer) ou de barras, situados em superquadras sem lotes definidos (tecido sem lotes).

A síntese desse tipo pode ser verificada na ville radieuse corbusiana, de 1933, tida por críticos como uma utopia formal sobre a linha da tradição técnico-compositiva renascentista. Um plano referencial que irá marcar os projetos para CNs ao longo do século passado, caracterizados por um zoneamento socioespacial "puro e duro, com um espaço urbano extremamente compartimentado e funcional, apresentado como coerente e homogêneo” (FLORIN, 2001, p. 234, tradução nossa). ${ }^{31}$

Esse, um rigor rebatido igualmente nas CNs italianas do período fascista e nas navyé goroda da extinta União Soviética. Na Itália, as CNs fundadas entre 1922 e 1943, durante o regime de Benedito Mussolini, possuíam uma arquitetura dotada de um "aspecto monolítico, causado, salvo exceções, pelo plano de massas geométricos, monótonos e repetitivos que acompanharam a criação, ex-nihilo, de aglomerações tais como Guidonia, Mussolinia, Carbonia, Aprilia, Pomezia, Pontinia, Sabaudia, Acilia, Littoria ou Fertilia” (VALLAT, 2001, p. 175, tradução nossa). ${ }^{32}$

Na URSS, os planos das CNs eram considerados testemunhas de concepções urbanísticas dominantes. Cidade nova ou velha aglomeração, renovada ou reconstruída, a organização interna do espaço urbano soviético foi marcada por uma “impressão de monotonia e de repetição, devido à homogeneidade dos moldes e

31 “[...] pure et dure, avec un espace urbain extrêmement compartimenté et fonctionnel, présenté comme cohérent et homogène.”

32 “[...] aspect monolithique, causé, sauf exception, par le plan de masses géométriques monotones et répétitives qui accompagnait la création, ex nihilo, d'agglomérations telles que Guidonia, Mussolinia, Carbonia, Aprilia, Pomezia, Pontinia, Sabaudia, Acilia, Littoria ou Fertilia.” 
dos materiais de construção industrializados, como pela disposição das unidades de habitação”. (BEAUJEU-GARNIER et al., 1982, p. 735, tradução nossa). ${ }^{33}$

As CNs socialistas podem, efetivamente, ser consideradas como um reflexo da ideologia e da organização da sociedade soviética. As condições de moradia e de equipamento, graças a um catálogo de normas muito rígidas, foram, por muito tempo, superiores àquelas das cidades antigas. A exclusividade de habitações coletivas, a dimensão generosa dos eixos de circulação e dos espaços verdes, mas também "certa mediocridade da construção e uma ausência de adaptação das normas ao contexto local revelam a concepção de planejamento do GOSSTROI (pode-se visitar uma casa da cultura em Moscou e encontrar a mesma em plena Sibéria ou Uzbequistão)”. (MERLIN, 1992, p. 9, tradução nossa). ${ }^{34}$ A CN socialista era, antes de tudo, considerada um complexo "trabalho-repouso-vida cotidiana”, com residências quase exclusivamente coletivas e com edifícios cuja altura podia variar entre dois e 16 pavimentos, de acordo com o tamanho da cidade e dos bairros. Tal qual a CN de Naberejnye Tchelny, na Rússia, fundada para recepcionar 330 mil habitantes na década de 1950. Ligada à indústria automotiva, à indústria petroquímica, à usina de energia e às funções turísticas, sua arquitetura se assemelha a qualquer outra navyé goroda da época, monótona e repetitiva.

Já nas cidades-satélites europeias, as composições volumétricas se resumiram, se assim podemos fazer, a grandes estruturas (tecido em megaestrutura) implantadas na região central, seguidas por barras residenciais de arquitetura pós-moderna entre o centro e a periferia (tecido sem lotes) e residências isoladas nas zonas limítrofes dessas CNs (tecido espraiado) - um tipo pautado por uma arquitetura imposta, muitas vezes criticada por seus recém-chegados moradores e por especialistas e estudiosos.

33 “[...] impression de monotonie et répétition dues à l'homogénéité des moules et des matériaux de construction industrialisés, ainsi qu'à la disposition des logements."

34 "[...] une certaine médiocrité de la construction et une absence d'adaptation des normes au contexte local révèlent la conception de planification du GOSSTROI (on peut visiter la Maison de la Culture à Moscou et en trouver une en Sibérie ou en Ouzbékistan)." 
Em Saint-Quentin-en-Yvelines, uma das villes nouvelles do entorno parisiense, Jacques Guyard (1980, p. 31, tradução nossa) ${ }^{35}$ detectou 26 mil moradias criadas como "um imenso jogo de cubos disseminados sobre um território muito vasto, com falta de unidade morfológica e bairros separados por grandes espaços vazios”.

Especificamente, as megaestruturas - um “avatar do traçado” segundo Albert Levy (1992, p. 31, tradução nossa) ${ }^{36}$ - foram uma composição volumétrica à parte, defendida e aplicada pelo Team X, pelo Archigram e pelos metabolistas japoneses como resposta ao tipo funcionalista e setorizado modernista. Na Europa, os arquitetos Georges Candilis (1913-1995), Jaap Bakema (1914-1981), Aldo van Eych (1918-1999), Giancarlo de Carlo (1919-2005), Peter e Alison Smithson (1923-2003; 1928-1993) e Shadrach Woods (1923-1973) desenvolveram suas obras tendo as megaestruturas como organizadoras de espaços urbanos centrais, de cidades universitárias e de pequenos núcleos urbanos (RISSELADA; HEUVEL, 2005).

Os adeptos do uso da megaestrutura têm por ambição juntar duas necessidades: de um lado, encontrar a unidade de comunidade social perdida e que se exprime na cidade tradicional pela continuidade morfológica do tecido urbano; de outro, opor-se aos esquemas estáticos do urbanismo funcionalista. Seria uma estrutura capaz de entrelaçar e repercutir até na escala do indivíduo as evoluções e as transformações de uma sociedade em mutação, submissa ao progresso das ciências.

Foi durante os “30 gloriosos” (1945-1975) e, em particular, durante os anos 1960 que os arquitetos se apropriaram do progresso científico e tecnológico para propor cidades utópicas, todas tendo as megaestruturas como núcleo gerador do espaço urbano. A variedade dessa “arquitetura de papel”, como apelidou Michel Ragon (1967), pode ser apreendida nas inúmeras propostas urbanísticas da época. Vejam-se: a Cidade sobre a água (de Warren Chalk); as Cidades espaciais (de Yona Friedman); o Entonnoir habitable (de Walter Jonas); a Walking City (de Ron

35 “[...] un immense jeu de cubes étalés sur un très vaste territoire, dépourvu d'unité morphologique et de quartiers séparés par de grands espaces vides.”

36 "[...] l'avatar du tracé." 
Herron); a Manhattan sob bolha (de Buckminster Fuller); a Casa empilhada (de Wolfgang Döring); as Células pneumáticas (de Jean-Pierre Jungmann); o Living Pod (de David Green); a Cidade sob o Sena (de Paul Maymont); a Cidade flutuante (de Stanley Tigerman); a Cidade em terraço (de Cesar Pelli); a Acrologie (de Paolo Soleri); a Space City (de Lockheed Missiles); a Plug in City (de Peter Cook); o Pneumocosmo (de Hausrucker); a Tóquio sobre o mar (dos Metabolistas japoneses). Todos esses projetos tinham e têm como denominador comum serem utopias tecnológicas (ROUILLARD, 1998).

Em face desse urbanismo tecnológico imposto, pouco contextualizado e, por que não, histérico, Cristoforo Sergio Bertuglia et al. (2004) elaboram um protesto. Para os autores, as CNs não podem ser consideradas ideais, pois devem superar a fase de pura idealização, aquela que detém os cânones urbanísticos, arquitetônicos e estéticos, para obter a perfeição e a eternidade. Segundo os autores:

\begin{abstract}
As cidades novas não são concebidas como sistema perfeito e imutável, mas como organismos em contínua evolução, flexíveis e capazes de adaptar-se às inevitáveis mudanças econômicas, tecnológicas e culturais da cidade contemporânea. As cidades novas se diferenciam das cidades ideais, não buscando a perfeição ou a eternidade, não sendo pensada como cidade imutável, mas, sim, por serem concebidas visando à flexibilidade e capazes de adaptar-se às mudanças da sociedade. (BERTUGLIA; TICH; STANGHELLINI, 2004, p. 96-97, tradução nossa). ${ }^{37}$
\end{abstract}

\footnotetext{
37 "Le città nuove non sono concepite come un sistema perfetto e immutabile, ma come organismi in continua evoluzione, flessibili e adattabili agli inevitabili cambiamenti economici, tecnologici e culturali della città contemporanea. Le città nuove differiscono dalle città ideali, non cercano la perfezione o l'eternità, non essendo pensate come una città immutabile, ma piuttosto come concepite per la flessibilità e capaci di adattarsi ai cambiamenti nella società."
} 
Essa flexibilidade foi adotada em algumas CNs marroquinas. Na região de Agadir, as CNs de Tassila, Agadir Sud-Est, Tama (Enza) foram encomendadas ao Institut d'Aménagement e d'Urbanisme de la région d'Ile-de-France (IAURIF), com o intuito de acolher uma parte do crescimento urbano da região de Agadir. O IAURIF seria responsável pelo conjunto de processos de concepção, desde a definição até o estabelecimento de documentos diretamente operacionais, como o plano de loteamentos. Embora realizado em país externo (Marrocos), houve uma real preocupação em aplicar características próprias do urbanismo vernacular marroquino, como, por exemplo, “a diversidade de lotes (15 tipos diferentes), com um tecido urbano denso e de baixo gabarito, e a presença de hierarquia viária; além da adequação ao sítio e a elementos da paisagem local” (BECARD, 1984, p. 88, tradução nossa). ${ }^{38}$

Tais são alguns exemplos que se somam aos demais tipos de tecido urbano e aos diferentes tipos de traçado a fim de favorecer uma percepção mais substanciosa sobre o projeto das CNs. Traçados e/ou tecidos, concebidos e planejados para atender às necessidades para quais as CNs foram criadas, compõem o quinto elemento do DNA das CNs, aqui exposto de modo a garantir o entendimento desse tipo urbanístico, desde seu planejamento até sua concretude. Processo efetivado durante um tempo próprio, como veremos na derradeira parada desta nossa viagem.

38 “[...] la diversité des lots (15 types différents), avec un tissu urbain dense et un gabarit bas, et la présence d'une hiérarchie routière; outre l'adaptation au site et aux éléments du paysage local.” 


$$
y
$$




\section{Cidades novas e o tempo}

Sexta parada: algum lugar do Centro-Norte de nosso país.

Para esta última parada, optei por não definir uma ou mais CNs, visando a introduzir aspectos relativos ao tema abordado, o tempo. Optei por levar os colegas viajantes a um período recente da história de nosso país, marcado pela continuação da “Marcha para o Oeste”, após a década de 1940, que avança pelo governo de JK e permeia os anos do Regime Militar até fins de 1980. Um corte temporal que revelará políticas econômico-sociais contribuindo para o surgimento de CNs, principalmente nas regiões Centro-Oeste e Norte do Brasil.

Já vimos em capítulos anteriores que, ao longo do século XX, inúmeras políticas públicas adotadas refletiram a prática de CNs em estreita relação com frentes dinâmicas de atividade econômica ou em apoio a medidas de arrancada ou intensificação do desenvolvimento. A lavoura cafeeira e a subsequente constituição da rede ferroviária de São Paulo e do Paraná nos inícios do século e a getulista "Marcha para o Oeste” (1938) exemplificaram tal processo. Aqui, veremos que todas elas foram seguidas pela Fundação Brasil Central (1943), coroadas pela transferência da própria capital federal para o planalto central (1960), mantendo-se após o golpe militar de 1964, quando um governo autoritário, centralizador e tecnocrático tirou partido das CNs, utilizando-as em planos implementados para os mais variados fins, sob a condução dos ideais de desenvolvimentismo e integração nacional.

Após uma fase preliminar centrada na construção intensiva de ferrovias em direção ao oeste paulista e ao norte paranaense (ver introdução do capítulo 1), na década de 1940 a frente pioneira se deslocaria rumo ao norte, objetivando a conexão e a ocupação da região amazônica via Centro-Oeste. Um dos primeiros indicadores 
desse deslocamento foi a fundação, em 1933, de Goiânia, nova capital de Goiás e segunda CN administrativa da República.

Além do controle do território, preocupação da Fundação Brasil Central (FBC), ${ }^{1}$ criada em 1943, a nova frente de urbanização era motivada também pelos interesses do capital imobiliário, das empresas ferroviárias e da agricultura intensiva para exportação. Algo verificável na Expedição Roncador-Xingu, um dos principais eixos da Marcha, que “deslocaria a fronteira para o sudoeste goiano e para os vales dos rios Araguaia, Xingu e Tapajós, construindo estradas, pistas de pouso, fazendas de gado, cidades, enfim, semeando modernidade pelas mãos dos expedicionários, bandeirantes do século XX” (MORAES, 2003, p. 82).

Logo esse quadro de urbanização seria alterado pela adoção de outras classes de ações promotoras de CNs, em especial: 1) a transferência da capital federal do Rio de Janeiro para o planalto central em 1960 - contribuindo com uma leva própria de CNs, até hoje em expansão: além de Brasília, as cidades-satélites brasilienses, como Taguatinga (1958) e Guará I (1967); 2) a construção da rodovia Belém-Brasília da década de 1950 à de 1970; e 3) as políticas específicas adotadas durante a ditadura militar, em atendimento a demandas geopolíticas e/ou de infraestrutura.

Ao longo do século passado, identificam-se ganhos consideráveis na infraestrutura nacional como suporte ao desenvolvimento, num primeiro momento restritos aos locais mais dinâmicos e à produção econômica neles em vigor - como as ferrovias do período cafeeiro. Foi o presidente Washington Luís (1926-1930) que, ao discursar no Congresso Nacional em 1927, lançou a semente do “rodoviarismo” em escala nacional, ${ }^{2}$ conforme defendeu: “Governar é povoar, mas não se povoa sem se abrir estradas e de todas as espécies. Governar é, pois, fazer estradas.” (UNB, 1972, p. 66). Bem mais tarde, em 1944, seria posto em prática o Plano Rodoviário

1 A sede da FBC foi localizada na CN de Aragarças (1943), na região noroeste de Goiás, estrategicamente construída para receber seus funcionários.

2 Como já fizera no estado de São Paulo, cuja política rodoviária data de 1913, por iniciativa justamente sua quando deputado estadual, acelerada durante seu mandato de governador, entre 1920 e 1924 (FICHER, 2005). 
Nacional, embora com resultados de pouca monta. Outra tentativa, de 1948, foi elaborada pelo deputado federal Jales Machado da Siqueira (1895-1975), que buscava incluir, na política rodoviária, a construção de rodovias perimetrais e radiais, interligando as diferentes regiões e tendo por foco o planalto central, onde deveria se localizar a futura capital da nação.

O Plano Rodoviário Nacional seria referência para o Plano Quinquenal de Obras Rodoviárias, elaborado no governo Juscelino Kubitschek (1956-1961) para:

[...] atender às necessidades sócio-econômicas mais prementes, compreendendo as regiões onde a economia atingirá maior expressão, e as regiões férteis de economia latente ou que, apesar do isolamento do oceano, explodiam e eram objeto de uma intensa e desordenada ocupação. (UNB, 1972, p. 68).

Para fomentar o mercado interno pela derrubada das barreiras de isolamento entre áreas mais e menos economicamente desenvolvidas, foram então propostas, entre outras, as rodovias Belém-Brasília, Brasília-Fortaleza, Brasília-Acre, Cuiabá-Santarém e Transamazônica, empreendimentos acelerados no governo militar, tendo por base o II Plano Nacional Rodoviário. As rodovias “plantadoras” de CNs contribuíram para “a instalação de 100.000 famílias” às suas margens, e, de quebra, controlaram e direcionaram o fluxo migratório (BRASIL, 1972, p. 28).

A rodovia Belém-Brasília (atual BR-153) - conhecida popularmente como a “Estrada das Onças” - possui mais de dois mil quilômetros de extensão, interligando a capital do Pará à capital federal, perpassando Maranhão, Tocantins e Goiás. Vinculada inicialmente à FBC, seu primeiro trecho, de Anápolis à CN de Ceres e depois a Uruaçu, foi implantado na década de 1940, após a criação da Colônia Agrícola 
Nacional de Goiás (Cang). ${ }^{3}$ Mas a sua data oficial é 15 de maio de 1958, quando foi promulgado o Decreto $n^{\circ}$ 43.710, criando a Rodobrás - comissão executiva responsável por sua construção, vinculada à Superintendência do Desenvolvimento da Amazônia (Sudam) e dirigida, inicialmente, pelo engenheiro agrônomo Bernardo Sayão. Apesar de inúmeros percalços na fase inicial, o propósito de integrar a Amazônia ao sul do país prosseguiria e, em 1968, quando a rodovia já contava com 120 núcleos urbanos e dois milhões de habitantes em sua área de influência, foi concluído o seu estudo de viabilidade econômica, o qual estabelecia o ano de 1973 como prazo final para a conclusão de sua pavimentação (BRASIL, 1971).

Essa estrada, assim como as demais posteriormente, corroboraria tanto o crescimento de núcleos urbanos existentes, retirando-os da economia de subsistência - como Porangatu, Uruaçu e Imperatriz, denominadas de “cidades renovadas”-, quanto o surgimento de CNs. Estas últimas podem ser divididas em dois tipos: os acampamentos da Rodobrás (aglomerados de poucas construções, localizados em trechos da rodovia que demandavam maior tempo de obra) e os novos núcleos de povoamento (implantados pontilhando distâncias relativamente iguais ao longo de seu traçado). Mais ainda, graças à dinamização econômica, somando-se às atividades rurais pré-existentes, surgiriam também CNs em função da prestação de serviços à estrada (postos de combustível) ou pelos serviços que a estrada proporcionava. No grupo de CNs da Belém-Brasília, encontram-se: Paragominas (PA), Estreito (MA), Araguaína (TO), Guaraí (TO), Paraíso do Tocantins (TO), Gurupi (TO), Alvorada (TO), Ceres (GO), Abadiânia (GO) e Alexânia (GO). Contudo, do ponto de vista urbanístico, tais núcleos nem sempre revelaram projetos minuciosamente elaborados (BRASIL, 1972).

3 Criada em 1940, no vale do rio São Patrício, município de Ceres, a Cang atraiu grandes levas de lavradores. Dado os seus resultados, na mesma década foram estabelecidas colônias semelhantes nos municípios de Rubiataba, Rialma e Carmo do Rio Verde, todos em Goiás (MORAES, 2003). 
Figura 16: Rodovia Belém-Brasília

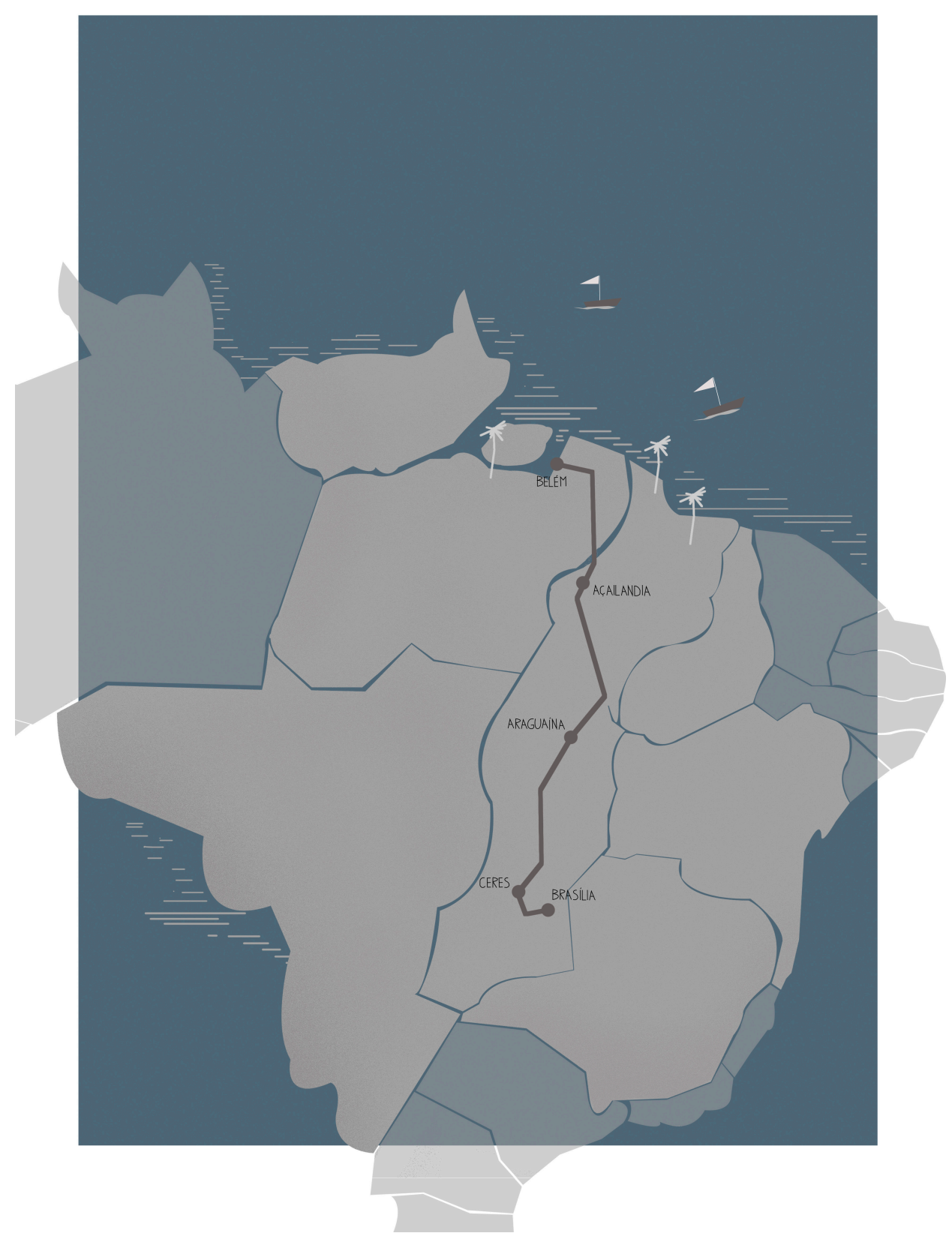


A urbanização advinda do incremento populacional proporcionado pela rodovia se deu de modo desordenado, alterando fisionomias e funções. Cidades dos séculos XVIII e XIX, como Uruaçu e Jaraguá, tiveram seu traçado original absorvido por novos loteamentos, e o antigo núcleo de Porangatu foi abandonado pela migração de seus habitantes rumo a um novo assentamento (UNB, 1972). No que se refere às CNs, em geral apresentavam planos similares, com traçado em malha ou linear, definição de trama viária rígida e regulamentação do uso do solo - salvo exceções, como Abadiânia que, realocada para uma nova sede, recebeu um traçado similar ao de Goiânia (patte-d'oie). Quanto à sua infraestrutura, dispunham de serviços insatisfatórios de água, luz e esgoto; como centralidade, diferenciavam-se das mais antigas por não terem a praça como local de maior importância e, sim, o comércio próximo à estrada.

Processo semelhante seria desencadeado pela construção da Transamazônica, fruto de "uma proposta concreta de hierarquização urbana feita pelos organismos competentes em função de um programa de colonização” (BRASIL, 1972, p. 14). O governo militar, ao enfrentar a velha problemática de povoamento de extensas áreas ainda devolutas, ${ }^{4}$ apresentou como solução a implantação de uma rede urbana de penetração, visando à segurança das fronteiras e à colonização planejada. O programa "Integrar para desenvolver” definia para a Amazônia duas linhas de ação: 1.) integração física, econômica e cultural; e 2.) expansão da fronteira econômica, absorção de excedentes populacionais de outras áreas e elevação do nível de renda e bem-estar na região (BRASIL, 1972, p. 79-80).

O seu plano de ocupação, coordenado pelo Instituto Nacional de Colonização e Reforma Agrária (Incra), consistia em criar áreas rurais produtivas, estendendo-se por 100 quilômetros de cada lado do complexo rodoviário e abrangendo aproximadamente 2.300.000 km² (BRASIL, 1972, p. 83). As áreas foram classificadas segundo um tipo funcional: lotes rurais, ocupações urbanas, reservas florestais

4 Até a década de 1970, a Amazônia, apesar de representar 3/5 da área do território nacional, abrigava apenas 7\% da população total brasileira (BRASIL, 1974). 
e biológicas, reservas industriais, reservas para obras de infraestruturas e áreas inaproveitáveis.

A rede urbana deveria obedecer a uma hierarquia, conforme a seguinte gradação e nomenclatura (BRASIL, 1972, p. 84-85):

- Agrovila (centro menor): comunidade rural-urbana oferecendo ensino primário, serviço social e de saúde, pequeno comércio e habitações;

- Agrópolis (centro de segunda ordem): comunidade urbano-rural contabilizando 22 agrovilas, com 6 mil habitantes cada; e

- Rurópolis (centro microrregional): comunidade de agrovilas e agrópolis, de vida urbana mais intensa.

Ao longo da Transamazônica, deveria haver uma agrópolis a cada 40 quilômetros e uma rurópolis a cada 140 quilômetros, induzindo ao estabelecimento de uma malha de CNs de baixa densidade, com cerca de 6,5 hab. $/ \mathrm{km}^{2}$. Tal escala crescente de urbanização proporcionaria, em condições ideais: flexibilidade, contato entre áreas predominantemente rurais e urbanas e novas opções de crescimento à luz das experiências acumuladas. As CNs deveriam ser concebidas como "uma concentração adequada dos ingredientes humanos, científicos, tecnológicos, financeiros, industriais, sociais, culturais, comerciais, e outros necessários ao funcionamento de certas atividades indispensáveis ao desenvolvimento sócio-econômico” (BRASIL, 1972, p. 377). As infraestruturas básicas previstas eram: apoio financeiro, áreas de estocagem e conservação; serviços escolares e de saúde; comércio atacadista e varejista; oficinas de reparos etc. Dentre as CNs da Transamazônica, a mais conhecida é Marabá (1973), no Pará.

Fato é que tais rodovias propiciaram o desenvolvimento econômico e a urbanização, embora, para além de tais objetivos, houvesse uma lógica de mercado. Ao saírem do papel, as rodovias nacionais visavam a expandir o mercado consumidor - levando produtos manufaturados das regiões mais industrializadas - e 
a facilitar a circulação de produtos agrícolas e minerais - oriundos das regiões mais isoladas. A Belém-Brasília deveria servir para escoar produtos agrícolas de Goiás e do Maranhão para Belém e São Paulo, sem necessariamente repercutir em retorno econômico para as regiões produtoras. Igualmente a Transamazônica, que tinha em primeiro plano a extração e exportação de riquezas, mas deixava de lado a preocupação em colonizar e potencializar o progresso regional (UNB, 1972).

A intensificação da ocupação da floresta amazônica também se valeu de planos distintos daqueles vinculados às rodovias. Trata-se de uma série de programas formulados e colocados em prática por diferentes Ministérios (Agricultura, Interior, Minas e Energia), buscando suprir o déficit habitacional, capacitar de infraestrutura o espaço intraurbano e ordenar a ocupação territorial por meio de planos regionais. Nos anos 1970, por exemplo, o I Plano Nacional de Desenvolvimento (I PND), o Programa de Integração Nacional (PIN) e o Plano Nacional Territorial (PNT) tinham por especificidade a integração e o desenvolvimento nacionais. A lista é longa e incluía ainda os planos Prodoeste, Polocentro, Provale, Proterra, Polamazônia e os projetos Aripuanã-Humboldt e Radam, todos de caráter colonizador e coordenados por superintendências específicas (como Sudam e Suframa) ou pelo Incra.

Sob o comando do Serviço Federal de Habitação e Urbanismo (Serfhau), CNs foram propostas não somente em faixas pioneiras, assistidas por rodovias interregionais (Belém-Brasília e Transamazônica), mas para a construção de polos siderúrgicos e petroquímicos e de hidrelétricas (como exemplificam as CNs citadas na introdução do capítulo 3).

Com a extinção do Serfhau em 1974, a continuidade do processo foi atribuída, primeiramente, à Comissão Nacional de Regiões Metropolitanas e Políticas Urbanas (CNPU, 1974-1979), orientada por seu II Plano Nacional de Desenvolvimento (II PND, 1974). Posteriormente, foi substituída pelo Conselho Nacional de Desenvolvimento Urbano (CNDU, 1979-1985), responsável pela Política Nacional de Desenvolvimento Urbano (PNDU, 1979). 
A CNPU, ao formular o II PND, delimitou algumas ações graduadas: controle, dinamização, disciplina, promoção e/ou contenção. Para as regiões Centro-Oeste e Norte, foram previstos programas abrangendo os núcleos urbanos da perimetral norte, do curso do rio Amazonas, da Transamazônica, do eixo Belém-Brasília, de cidades do Centro-Oeste e da região geoeconômica do Distrito Federal.

Um desses planos, o Programa de Polos Agropecuários e Agrominerais da Amazônia (Polamazônia), lançado no governo Geisel (1974-1979), consistia no investimento em 15 polos de desenvolvimento regional com recursos provenientes do PIN e do Proterra, visando a obras de infraestrutura, pesquisas mineralógicas e trabalhos de regularização fundiária. Áreas da “Amazônia Legal” foram selecionadas estrategicamente em função de suas potencialidades agropecuárias, agrominerais e agroindustriais: 1) Xingu-Araguaia; 2) Carajás; 3) Araguaia-Tocantins; 4) Trombetas; 5) Altamira; 6) Pré-Amazônia Maranhense; 7) Rondônia; 8) Acre; 9) Juruá-Solimões; 10) Roraima; 11) Tapajós; 12) Amapá; 13) Juruena; 14) Aripuanã; e 15) Marajó. Como apoio às frentes pioneiras, além do incremento econômico de núcleos existentes, deveriam ser criadas "23 CNs, de 8 a 80 mil habitantes, até o ano dois mil” (BRASIL, 1974, p. 63).

Dentre as áreas estipuladas, Aripuanã (MT) recebeu atenção especial do Ministério do Planejamento, do Interior e da Educação e Cultura e do governo estadual, por meio de convênio específico firmado em 1973. Denominado Projeto Aripuanã-Humboldt, previa: a implantação do núcleo pioneiro de Humboldt; a construção de rodovia ligando Humboldt a Vilhena (470 quilômetros); um programa de pesquisas florestais, de solos e recursos naturais; e outros de interesse científico. Como atrativo a mais para o capital privado e para imigrantes de outras regiões, entre Juruena e Aripuanã foram alienados cerca de dois milhões de hectares de terras a particulares. Estas permitiram o surgimento de inúmeras CNs como: Sinop (1974), Alta Floresta (1975), Juruena (1975), Juína (1977) e Paranaíta (1978).

Como último episódio dessa empreitada inacabada de colonização da hinterlândia, o estado de Goiás foi desmembrado com a criação do estado de 
Tocantins, após a redemocratização em 1985. Dessa alteração resultou Palmas, a mais recente cidade capital projetada do país.

Independentemente da postura ideológica e dos meios nada democráticos adotados pelo regime militar - infelizmente sendo justificados pelos fins - para colocar suas empreitadas em prática, pôde-se verificar uma produção urbana inédita. Não somente em termos numéricos, dada a criação de municípios e a resultante urbanização, mas também pela diversidade de estratégias e métodos aplicados, profissionais envolvidos, tipologias urbanísticas empregadas e, acima de tudo, pelas profundas consequências que teve para a organização territorial e demográfica do país.

Um período da história pautado no avanço de frentes pioneiras, modificando as divisas do desenvolvimento, que gerou “a construção progressiva de uma rede urbana de apoio, hierarquizada segundo suas funções, para sua eficiente incorporação à economia nacional”. (BRASIL, 1971, p. 10). Um planejamento que tomou partido da CN como uma ferramenta essencial, deveras utilizada como mecanismo de efetivação de ações desenvolvimentistas - apoio a construção de infraestruturas de grande porte e a exploração de novas atividades econômicas - e de ações integradoras - base atrativa de migração para as regiões Centro-Oeste e Norte. ${ }^{5}$

Um cenário revelador do sexto e último elemento do DNA das CNs: o tempo. Tempo presente antes (gestação), durante (nascimento) e após (desenvolvimento), a fundação dessas e das demais CNs conectando empreendedor, função, sítio, profissional e projeto num único propósito. Tempos relativamente precisos em cada caso e que marcam a transformação de uma CN em uma cidade.

\footnotetext{
5 A estratégia estava "na conciliação da agricultura e da indústria, com o aumento do emprego da mão de obra e a busca da expansão do mercado interno” pela “incorporação de novas áreas à economia nacional” (BRASIL, 1971, p. 111).
} 


\subsection{Da cidade nova à cidade}

Brasília é construída na linha do horizonte. Brasília é artificial. Tão artificial como devia ter sido o mundo quando foi criado. Quando o mundo foi criado, foi preciso criar um homem especialmente para aquele mundo. Nós somos todos deformados pela adaptação à liberdade de Deus. Não sabemos como seríamos se tivéssemos sido criados em primeiro lugar e depois o mundo deformado às nossas necessidades. Brasília ainda não tem o homem de Brasília. Se eu dissesse que Brasília é bonita veriam imediatamente que gostei da cidade. Mas se digo que Brasília é a imagem de minha insônia vêem nisso uma acusação. Mas a minha insônia não é bonita nem feia, minha insônia sou eu, é vivida, é o meu espanto. É ponto e vírgula. Os dois arquitetos não pensaram em construir beleza, seria fácil: eles ergueram o espanto inexplicado. A criação não é uma compreensão, é um novo mistério. - Quando morri, um dia abri os olhos era Brasília. Eu estava sozinha no mundo. Havia um táxi parado. Sem chofer. Ai que medo. - Lucio Costa e Oscar Niemeyer, dois homens solitários. - Olho Brasília como olho Roma: Brasília começou com uma simplificação final de ruínas. A hera ainda não cresceu.

Clarice Lispector, Os primeiros começos de Brasília, 20/6/1960 (LISPECTOR, 1984, p. 452)

A Brasília visitada por Lispector no início dos anos 1960 - a imagem de uma maquete em tamanho natural, a constituição de uma cidade em tempo real - nos direciona para um aspecto peculiar às CNs. Nelas, o tempo é exclusivo - “tempo de curta duração”. É o tempo próprio do empreendedor, da função escolhida e do local estratégico, seguindo lógicas político-econômico-sociais do 
momento; é o tempo presente na formação do projetista e refletido nos estilos de arquitetura e urbanismo em voga; é o tempo específico, aqui utilizado para compreender e conceituar as CNs.

Em artigo para a revista La Géographie de l'Histoire, os historiadores Camille Vallaux e Jean Brunhes (apud PENNA, 1958, p. 10-11) diferenciam a CN (por eles denominada de "cidade artificial”) da "cidade natural” por aspectos temporais. Para eles, a cidade natural apresenta uma "formação lenta, seguindo à sorte do desenvolvimento dinástico e resultante da combinação de elementos muito complexos e por vezes contraditórios”; a CN é criada repentinamente, dentro de um tempo relativamente preciso frente à amplitude de sua história, e por vontades claras e objetivas.

Ou seja, uma velocidade de constituição urbana diferente, assim conceituada pelo urbanista Vincent Fouchier (apud DIEBOLD; LEMONIER, 2001, p. 14, tradução nossa): ${ }^{6}$

As CNs parecem viver mais rápido que as demais, numa sociedade contemporânea que se transforma igualmente de modo mais e mais rápido. Elas são privadas de uma base e de uma permanência que constituem a história ou o patrimônio antigo; também a rapidez das evoluções, o peso dos fenômenos econômicos e demográficos, a obsolescência das formas urbanas são nelas mais sensíveis.

E mesmo que seu processo de materialização dure anos ou séculos, o tempo de uma CN é sempre a expressão de circunstâncias imperativas numa conjuntura crucial, um marco decisivo em sua história.

6 "Les villes nouvelles semblent vivre plus vite que les autres, dans une société contemporaine qui bouge aussi de plus en plus vite. Ils sont privés d'un socle et d'une permanence qui constituent l'histoire ou l'ancien patrimoine; la vitesse de l'évolution, le poids des phénomènes économiques et démographiques et l'obsolescence des formes urbaines y sont également plus sensibles." 
Ademais, se o tempo faz parte do processo das CNs, as CNs revelam características de seu tempo. Ao possuírem um urbanismo e uma arquitetura, estes refletem os tipos então predominantes e fazem das CNs, por vezes, museus a céu aberto - um retrato fidedigno dos estilos vigentes, verificados em Versalhes, Serra do Navio, Brasília e Marne-la-Vallée. Na França, as villes nouvelles foram, ao seu tempo, a novidade da prática urbanística. Segundo o político Jean-Pierre Combe:

Economia de energia, redes de calor, selo de qualidade, redes de cabos televisivos, grande prêmio de arquitetura, equipamentos integrados, programa pedagógico de construções solares, novas técnicas de construções, avanços espetaculares em transporte urbano: a lista é longa de inovações colocadas em prática nas cidades novas ao curso dos anos 1970 e hoje reproduzidas e desenvolvidas em outras cidades, entre as mais dinâmicas. (apud SMADJA, 1987, p. I, tradução nossa). ${ }^{7}$

São informações físicas e evolutivas que permitem ao estudioso e pesquisador de CNs situá-las na linha temporal da história (“tempo de longa duração”), ${ }^{8}$ com dados melhor captados após uma divisão estabelecida. Ao tripartir o tempo das CNs em ciclos, construção, fundação e desenvolvimento preliminar, busco revelar suas especificidades e mostrar fatos importantes conectados a cada um deles.

7 “Économies d'énergie, réseaux de chaleur, label de qualité, réseaux de télévision par câble, architecture du grand prix, équipements intégrés, programme pédagogique de construction de bâtiments solaires, nouvelles techniques de construction, avancées spectaculaires en matière de transport urbain : la pratique dans les villes nouvelles au cours des années 1970 et aujourd'hui reproduite et développée dans d'autres villes, parmi les plus dynamiques.”

8 Para efeito de estudos, a data a ser considerada como origem de cada CN pode variar, sendo sempre escolhida a mais antiga e não a de fundação, seja ela: a decisão do empreendedor, a data do concurso para o projeto, o lançamento da pedra fundamental. Para Brasília, considero o ano de 1957, e não o de 1960, como sua origem. Datas mais distantes do período de fundação devem ser analisadas e mencionadas nos estudos, como o período de delimitação do quadrilátero do Distrito Federal pela Missão Cruls (fins do século XIX). 
O primeiro, ciclo de construção ou ciclo gestacional, é o mais importante para entender e compreender as CNs. Trata-se do período no qual os demais atributos compositivos estão envolvidos, delimitados pela decisão do empreendedor e pela inauguração da CN. Ações como planejamento, projeto e construção caracterizam-no, possibilitando ao novo núcleo tomar forma e propiciar condições mínimas de habitabilidade e urbanidade aos seus futuros morados.

O período dessa primeira etapa varia conforme a necessidade, o jogo de interesses, o tamanho e outras especificidades ligadas ao processo de cada CN. Variam desde prazos mais curtos, como Brasília (três anos; 1957-1960) e Goiânia (quatro anos; 1933-1937), até prazos mais longos, como Santos (14 anos; 1896-1910) e Barcelona (20 anos; 1855-1875).

Processos rápidos podem ser verificados igualmente na Itália e na França. No governo de Mussolini, as città di fondazione "brotaram em alguns meses. A primeira pedra de Littoria foi colocada em 30 de junho de 1932 e sua inauguração foi em 18 de dezembro de 1932; Sabaudia foi construída entre agosto de 1933 e abril de 1934; e Pontínia entre outubro de 1934 e abril de 1935” (VALLAT, 2001, p. 175, tradução nossa). ${ }^{9}$ Na França, a criação das villes nouvelles foi decidida num curto período. Em 1965, o ato que sancionou o nascimento das CNs francesas foi um plano territorial inovador e ambicioso (GUYARD, 1982), coordenado pela “Direção Geral do Distrito da Região de Paris”, com as cinco CNs fundadas ainda no início dos anos 1970. Agilidade que qualifica as villes nouvelles como "realizações originais, tanto em resultados como em procedimentos de implementação" (SUDOUR, 1987, p. 42, tradução nossa). ${ }^{10}$

Paralelamente, há processos mais arrastados, como os identificados na Coreia do Sul e na Polônia. No país asiático, a CN de Kangnam demorou 15 anos, entre 1970 e 1985, para ser fundada ao sul do rio Han, possuindo três distritos distintos

9 “[...] germé dans quelques mois. La première pierre de Littoria a été posée le 30 juin 1932 et inaugurée le 18 décembre 1932; Sabaudia a été construit entre août 1933 et avril 1934; et Pontínia entre octobre 1934 et avril 1935.”

10 “[...] réalisations originales, à la fois en termes de résultats et de procédures de mise en œuvre." 
e áreas residenciais para classes mais abastadas (DAEWOO CORPORATION, 1998). Já na Polônia, o tempo gestacional mais largo de suas CNs se justifica pela “demora na implementação de vários estágios de desenho. Uma razão burocrática e não técnica” (WAWRZYNSKI, 1986, p. 37, tradução nossa). ${ }^{11}$

Com a cidade relativamente constituída, apta a funcionar, segue-se o segundo período, ciclo de fundação ou nascimento da CN, marcado pela entrega da cidade aos seus futuros habitantes: uma data simbólica para a história de cada CN.

Trata-se de um flash, um momento de clareza frente ao período precedente bem como ao seu desenvolvimento. Tal precisão é fixada pela presença, na maioria dos casos, por um dia, um mês, um ano de fundação. Isso fica claro com a CN de Ali Mendjeli (Argélia): proposta inicialmente em 1974 (data referencial para estudos), sua pedra inaugural foi colocada somente em 1991, sendo ocupada por moradores a partir de 10 de abril de 1999, data de sua fundação (BOUMAZA, 2006).

Após o conhecimento público da existência da CN, vem o ciclo de desenvolvimento preliminar, quando a cidade fervilha com a chegada de novos habitantes, novas construções e pelos arremates finais no grande canteiro de obras. Momento de transformação rápida, se comparado com cidades de origem espontânea, que permitirá à nova cidade construir uma identidade própria. Período que pode demorar, segundo condições político-econômico-sociais, de alguns anos a décadas.

É durante esse ciclo que as previsões (população e dimensão) realizadas durante seu planejamento são colocadas à prova. Na Austrália, a CN de Monarto foi planejada para alcançar suas metas em dez anos (RUSHMAN, 1976). Na França, os projetos urbanos das villes nouvelles surgiram com uma previsão de 30 a 40 anos para atingir a população máxima e uma possível independência em relação à cidade-mãe (TILLIETTE, 1985). Na Inglaterra, o plano da nova “cidade-campo” de Tillingham Hall, fundada em 1985, recebeu um programa de investimentos de 10

11 “[...] a delay in the implementation of various stages of design. A bureaucratic and non-technical reason $[\ldots] ”$. 


\section{Cidades novas}

anos, até que a cidade alcançasse o fim de sua fase de desenvolvimento preliminar (SHOSTAK; LOCK, 1985).

Em alguns países em via de desenvolvimento, as CNs foram resultados de “projetos ad hoc, concebidas para responder às necessidades criadas por programas de desenvolvimento regional ou nacional (de escala local ou nacional), respostas urgentes ou imediatas aos problemas de refugiados ou de empresas industriais particulares”. (SAFIER, 1977, p. 4, tradução nossa). ${ }^{12}$ Poucas dentre elas fizeram parte de uma política de longo prazo de redistribuição da população de um país. Porém, o crescimento destas CNs se mostrou mais rápido e mais forte que suas homólogas inglesas e francesas.

A CN de Kourou, na Guiana Francesa, planejada para sediar o Centre Spacial Guyanais (1964), de domínio francês, foi exemplo desse rápido desenvolvimento, conseguindo, em uma década, chegar à sua população estipulada (SAFIER, 1977). Brasília, 50 anos após sua fundação, mesmo não atingindo a população prevista para o Plano Piloto, se tornou “uma verdadeira aglomeração urbana após um longo período de juventude problemática, a eterna crise de adolescente” (MATHIEU, 2008, entrevista). Uma cidade amadurecida rapidamente, trazendo consigo uma dezena de jovens cidades-satélites.

Essa variação temporal está condicionada a um conjunto de fatores não previstos durante o ciclo gestacional. Segundo Vincent Fouchier (apud DIEBOLD; LEMONIER, 2001, p. 13, tradução nossa), ${ }^{13}$ as CNs “foram planejadas num período de evolução demográfica e econômica cujos efeitos não foram similares ao de seu desenvolvimento”. Na Antiguidade, antigos núcleos coloniais romanos no Oriente Médio foram redesenhados após sua independência, conforme aspectos socioculturais locais (KOSTOF, 1999). Nos EUA, a CN de Circleville, em Ohio, teve seu

12 “[...] projets ad hoc conçus pour répondre aux besoins créés par les programmes de développement régionaux ou nationaux (échelle locale ou nationale), les réponses urgentes ou immédiates aux problèmes de réfugiés ou d'entreprises industrielles particulières.”

13 "Les villes nouvelles ont été planifiés dans une période d'évolution démographique et économique dont les effets n'étaient pas similaires à ceux de son développement." 
traçado modificado após sua fundação em 1810 por questões especulativas do solo urbano. Na Espanha, o projeto da CN de Riera de Caldes teve que ser redimensionado após crises econômicas e políticas nos anos 1970 (CARRERAS, 1986).

Figura 17: Circleville

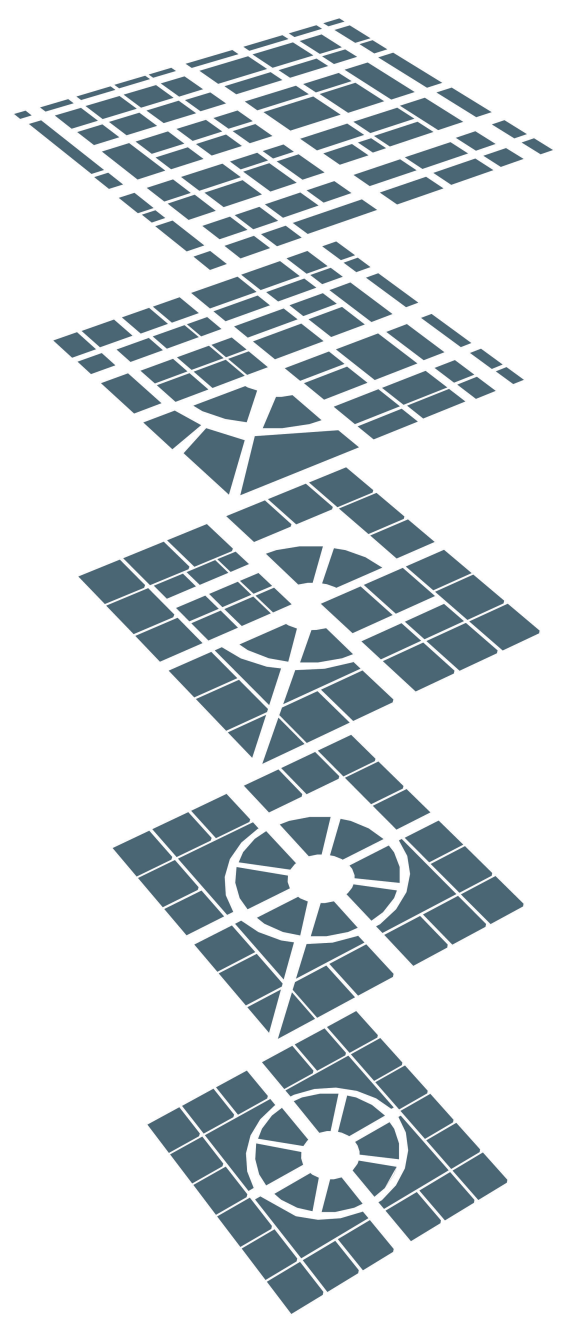


Além disso, nem toda cidade que apresente um rápido crescimento pode ser considerada uma CN. Na Polônia, 24 cidades apresentaram tal evolução entre as décadas de 1960 e 1970, dentre as quais somente quatro correspondem à nossa definição de CN, construídas segundo um urbanismo bem elaborado. Para Haumont (1997a, p. 85, tradução nossa), ${ }^{14}$ a origem de tal crescimento urbano acelerado deve-se, no caso polonês, a:

[...] cidades despovoadas durante ou logo após a guerra; cidades com rápido desenvolvimento após o descobrimento de jazidas de carbono ou cobre; cidades concebidas como centros importantes de industrialização socialista e de descongestionamento de cidades antigas; cidades operárias concebidas para abrigar trabalhadores de grandes usinas; cidades que se desenvolveram graças à industrialização ou à função administrativa.

A maturidade de uma CN - o tornar-se uma cidade - é conquistada quando ela adquire identidade própria, somada à sua emancipação e independência político-econômica (municipalização). Como exemplo específico, na França, a administração de suas CNs foi determinada pela Lei Boscher, de 10 de julho de 1970, mas sem clareza ou definição de qual instituição teria responsabilidade de fato sobre as villes nouvelles. Anos mais tarde, o cargo foi firmado no Établissement Public d'Aménagement (Estabelecimento Público de Planejamento), que se constituiu como monopolizador do papel de planejador: comprava os terrenos, os equipava, preparava os projetos da Zone d'agglomération nouvelle (Zona de aglomeração nova) e vendia os direitos de construção. Seu conselho era formado por metade de eleitores e metade de altos

14 “[...] villes dépeuplées pendant ou peu après la guerre; villes en développement rapide après la découverte de gisements de carbone ou de cuivre; les villes conçues comme des centres importants d'industrialisation socialiste et de décongestion des villes anciennes; villes ouvrières conçues pour loger les ouvriers des grandes usines; développés par l'industrialisation ou par des fonctions administratives." 
funcionários, embora o poder real pertencesse ao diretor, nomeado diretamente pelo primeiro-ministro (GUYARD, 1980). De modo mais objetivo, Paul Delouvrier (apud MONTAGU; SOKOLSKY, 1995, s.p., tradução nossa) $)^{15}$ afirmou que uma CN passa a ser uma cidade "quando seus cemitérios estiverem cheios”.

Independentemente dos critérios utilizados para qualificar as CNs como "cidades normais", o fato é que elas chegam a esse patamar em alguns anos ou décadas. Salvo quando fatores e contextos não as levam à morte, como ocorrido com CNs de exploração mineral em Goiás durante o ciclo do minério (séculos XVIII e XIX) e a experiência de Fordlândia na Amazônia, a cidade industrial de Henry Ford nos trópicos, atualmente tomada pela floresta. Casos que não desfazem a importância e a riqueza desse tipo urbanístico presente ao longo da história e vivo em diversas civilizações. Um tipo urbanístico atemporal em sua aplicabilidade, porém temporal em sua essência.

15 “[...] quand vos cimetières sont pleins.” 


$$
y
$$




\section{Considerações finais: no caminho, as cidades novas}

Ao fim desta jornada teórico-conceitual pelo universo das CNs, convido a todos a desembarcarem. Infelizmente peço isso não pela falta de exemplares a serem visitados, mas pela consciência de ter alcançado até aqui um conhecimento e um repertório instrumental suficientes para a realização de estudos futuros.

Se mais tempo tivéssemos, continuaríamos por outras CNs, no exterior e no Brasil. Poderíamos ir à Índia, visitar a CN de Auroville - conhecida também por Cidade do Amanhecer -, uma proposta utópica, projetada como uma espiral e respeitando os princípios do Ioga. Foi materializada em 1968 para ser um "local universal de educação e amizade entre os povos” (QUERRIEN; LASSAVE, 2005, p. 3, tradução nossa). ${ }^{1}$

Poderíamos ir à Holanda, descobrir a contemporânea Almere, uma cidade-satélite a leste de Amsterdã, fundada pelo governo holandês em 1971, a partir de uma política de urbanização controlada do território iniciada em 1918. Desse plano, 18 vilas e três CNs (Emmeloord, Lelystad e Almere) foram implantadas sobre terras conquistadas em áreas antes alagadas (flevoland ou pôlderes). Atualmente com 180 mil habitantes, Almere é destino obrigatório para estudiosos da arquitetura contemporânea, possuindo projetos de profissionais em destaque, como Rem Koolhaas e os escritórios MVRDV e SANAA.

Poderíamos ir à Inglaterra, aos Estados Unidos da América ou aos Emirados Árabes Unidos verificar as propostas de cidades embasadas por discursos de sustentabilidade. Veríamos Sir Peter Hall defender a sua Sustainable Social City 2000 na Inglaterra, uma cidade baseada nos princípios de cidade-jardim e caracterizada

1 “[...] lieu universel d'éducation et d'amitié entre les peuples.” 
por: transporte público, usos diversificados do solo, natureza próxima, casas com qualidade, economia balanceada, empregos para todos, serviços locais, acesso global etc. (HALL, 1996). Veríamos o escritor norte-americano Joel Garreau propor, em seu livro Edge City - Life on the New Frontier, de 1991, uma solução urbanística dos tempos atuais: as edge cities ou cidades-limites implantadas para além das zonas suburbanas, ocupando áreas gigantescas, do tamanho de cidades de médio porte, e embasadas por discursos ecologicamente corretos. Veríamos, ainda, o devaneio de arquitetos em Dubai, nos Emirados Árabes Unidos, ao imaginarem a cidade ecológica e autossustentável de Ziggurat, uma CN em megaestrutura piramidal, com instalação de turbinas eólicas e painéis solares para produção de energia, além de transporte feito por uma rede de monotrilhos e elevadores ligados por todo o prédio, sem a necessidade de automóveis.

Poderíamos ir ao Japão, relaxar em Tsukuda, a nordeste de Tóquio. Fundada no ano 2000, a CN japonesa nasceu com um novo conceito para os padrões de vida urbana: a slow life (vida pacata), contrapondo-se ao estresse e à agitação das grandes metrópoles. Novamente, a CN aparece como solução aos males da vida contemporânea.

Poderíamos ir a países africanos em conflitos, atentar para o uso das CNs como solução para abrigar milhares de refugiados de guerra. Criadas na urgência como um dispositivo de proteção para garantir a seguridade física, alimentar e sanitária de todos aqueles fugitivos de guerras, os campos de refugiados aglomeram dezenas de milhares de habitantes por períodos em geral muito mais longos que aquele de urgência. Edificados no começo como um autêntico deserto ou como um não lugar, os campos podem se tornar cidades. CNs surgidas a partir de um sistema de sobrevivência, como um "estabelecimento relativamente importante, denso e permanente de indivíduos socialmente heterogêneos, promotor de oportunidades de encontros, de trocas e de reelaborações identitárias entre todos seus habitantes” (AGIER, 2001, p. 130, tradução nossa). ${ }^{2}$

“[...] établissement relativement important, dense et permanent d'individus socialement hétérogènes, promoteur d'opportunités de rencontres, d'échanges et de ré-identifications identitaires entre tous ses habitants.” 
Considerações finais

Figura 18: Aureville

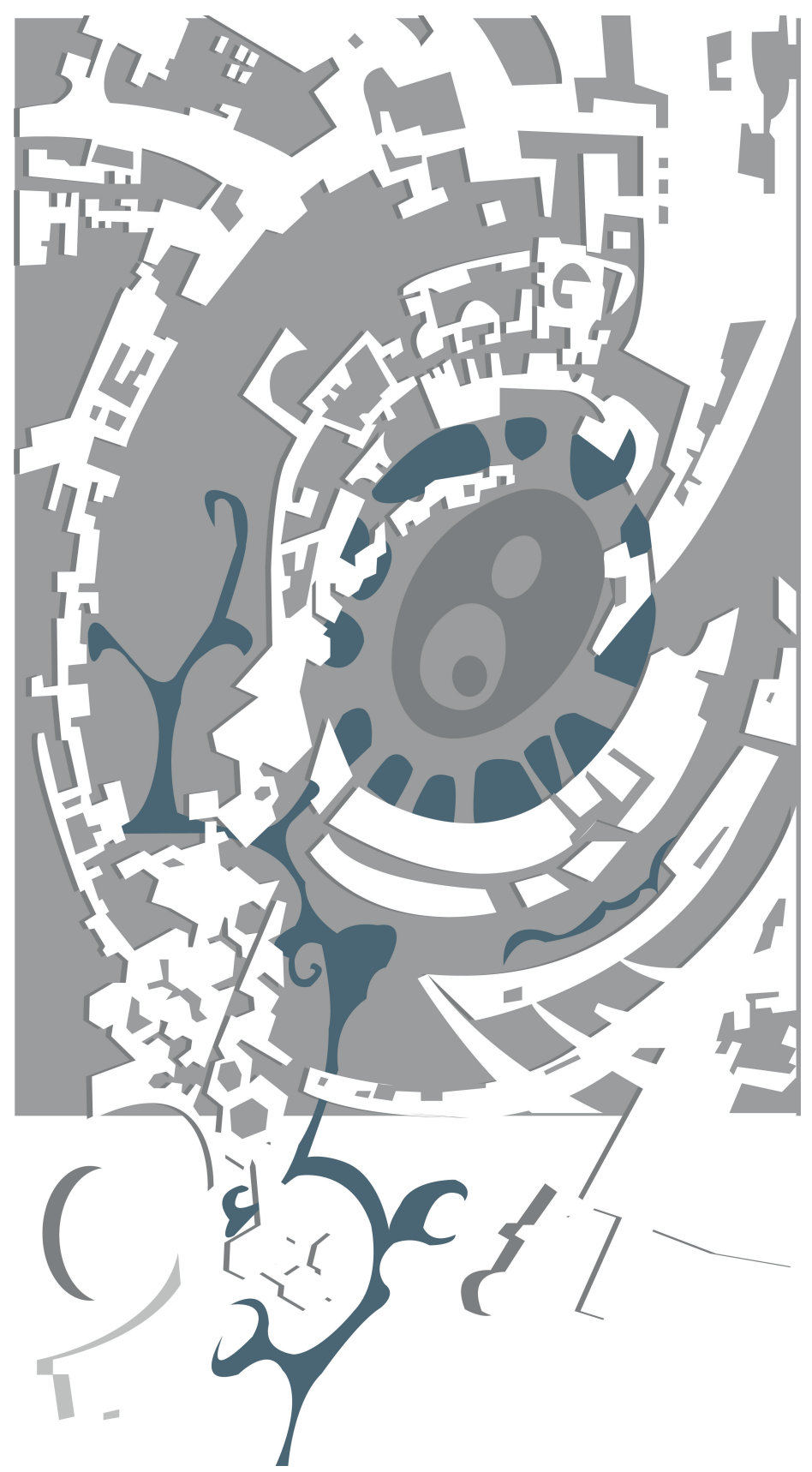


Poderíamos ir a um litoral, aguardar a elevação do nível dos oceanos e imaginar as CNs que surgirão em consequência das catástrofes naturais. Grandes estruturas, como a Lilypad do arquiteto belga Vincent Callebaut, uma cidade flutuante sobre o mar identificada como o novo espaço urbano da sociedade do futuro (ROUAT, 1996).

Poderíamos até ir ao mundo virtual, discutir as possibilidades de haver uma CN virtual, originária dos avanços tecnológicos, já profetizada por alguns estudiosos, como fez William J. Mitchell em E-Topia: urban-life - but not as we know it, de 1999.

Poderíamos, mesmo, ficar no Brasil e aguardar as futuras capitais que irão surgir com os novos estados e territórios previstos em projetos que tramitam, atualmente, no Congresso Nacional (previsão: 43 estados, 3 territórios e distrito federal). Campos férteis para a criação de CNs administrativas, essas ações já despertam o interesse de empreendedores - como ocorre na região de Carajás, no Pará -, que veem na compra de terras e no planejamento de futuras obras atividades altamente lucrativas.

Poderíamos, mas essas e outras possibilidades ficarão para uma próxima jornada.

\section{Afinal, o que são cidades novas?}

Ao encerrar este livro, recupero as principais ideias nele abordadas com intuito de certificar ao leitor que as respostas a tal questionamento inicial foram, por instante, delimitadas.

Certo da classificação das CNs como um tipo urbanístico, pude observar o contexto no qual elas se inserem, cercadas por aspirações utópicas e por realizações concretas. Cidades sonhadas, imaginadas, teorizadas e criadas a fim de servir aos ideais e às necessidades de um determinado período.

Em seguida, identifiquei as várias definições empregadas para um mesmo objeto, distintas conforme o momento histórico, os aspectos físico-sociais envolvidos e o interesse particular de seus pesquisadores. Definições, por vezes, pouco contextualizadas à nossa realidade, mas propícias à elaboração de um conceito funcional. Conceito este representado pelo DNA das CNs, no qual estruturei os seis 
elementos definidores desse tipo urbanístico: desejo, função, lugar, profissional, projeto e tempo, conectados à linha temporal da história.

De antemão, busquei relacionar en passant a origem das CNs a um conjunto de fatores mais abrangentes que os meros seis segmentos, ou seja, procurei constatar que elas nascem a partir de um contexto político-econômico-sócio-cultural propício. Neste livro, isso foi evidenciado nas introduções a cada capítulo, pela narrativa histórica do surgimento de alguns exemplares no Brasil. Pequenas histórias que expõem, de um lado, as conjunturas que favoreceram a criação dessas CNs e, de outro, as características que permitiram trabalhar determinado atributo.

Contudo, não basta apenas ter um cenário propício se não há, no processo, o agente starter. Assim, creditei ao empreendedor - o genitor das CNs - um papel fundamental na definição conceitual desse tipo urbanístico. O desejo, a vontade de criar uma CN parte, especificamente, da figura do empreendedor ou de um grupo deles, portadores de capital público e/ou privado. É ele quem assume o desejo, a intenção, o querer criar uma nova cidade; é ele quem promove as ações; é ele o responsável por assegurar capital para efetivar o empreendimento.

Junto ao desejo está a necessidade, dois atributos inseparáveis que surgem simultaneamente na história de cada CN. Necessidade traduzida pela função dominante, a função em destaque nos primeiros anos de vida da cidade recém-criada. Atributo no qual destaquei a multiplicidade, isto é, a variedade de funções dominantes existentes (12 até agora diagnosticadas). Atributo que marca no mapa genético das CNs a causa para a qual foram geradas.

Do desejo e da necessidade, passei ao ambiente natural, à implantação das CNs e suas particularidades. Nesse sentido, o lugar aparece como um elemento possuidor de dois aspectos importantes. O primeiro refere-se ao sítio e suas condicionantes geográficas, aquelas que irão favorecer a implantação da urbe, diretamente relacionados à atenção do(s) empreendedor(es) - estudo minucioso do local - e à função dominante - qualidades inerentes ao local. O segundo refere-se ao sítio como condicionante projetiva, em que o meio ambiente pode ou não ser considerado ao se 
desenhar o traçado e o tecido da $\mathrm{CN}$ - parâmetro de análise do projeto implantado. Sob e sobre o lugar selecionado, dados importantes se apresentam para uma maior compreensão das CNs.

A partir dessa trilogia preliminar, seguiram-se os atributos que caracterizam a materialização das CNs: o profissional e o projeto. O profissional, ou melhor, o urbanista - detentor de um conhecimento obtido em diversas áreas -, solitário ou auxiliado por uma equipe, é o responsável por tornar o desejo, o sonho, a motivação em realidade espacial, com menor ou maior grau de detalhamento, consoante o seu arcabouço técnico. Ao caracterizar a personagem, distingui-a de outra, o empreendedor, que não detém um saber-fazer cidades. Dois agentes separados neste livro, cada qual com seu papel específico na tarefa de construir CNs.

Do planejamento ao projeto, surgiram as CNs. Cidades planejadas ao serem, durante um período gestacional, alvo de uma preparação - antecipar-se ao que ainda não é, mas que tem a possibilidade de ser. Trata-se da elaboração de planos e ações visando à projetação unitária do espaço físico urbano. Projetos por mim classificados (CNs fechadas ou abertas; CNs em 2D ou em 3D) e exemplificados. O atributo mais detalhado neste livro em função do repertório profissional pessoal e como contribuição aos estudos na área da morfologia urbana.

Por fim, expus o tempo das CNs, o tempo específico a cada uma delas, o "tempo de curta duração”. Um tempo que separei em ciclos: gestacional, nascimento e desenvolvimento preliminar; período que se estende até a $\mathrm{CN}$ atingir sua maioridade e se tornar uma cidade. Tempo que percorre os demais atributos durante a precoce história de origem de cada CN. Um tempo intra-DNA, distinto daquele mais amplo e abrangente, conectado à história da humanidade.

O tempo histórico, ou “tempo de longa duração”, representado nesta obra pelos infindáveis exemplares visionados e construídos desde a Antiguidade até hoje, permitiu visualizar o percurso das CNs ao longo dos séculos. Um percurso marcado por mudanças nos aspectos político-econômico-sócio-culturais, pelos avanços tecnológicos, pelas diferentes abordagens de conhecimento, pelos adventos de novas teorias urbanas etc. 
Transformações que limitam cada CN a um período histórico diferente. Recortes temporais que contribuem para uma análise das CNs conforme os profissionais recorrentes, as variações formais no desenho urbano ou mesmo para verificar o uso de uma só função dominante em épocas distintas. Um universo de fatores que gera CNs específicas. Uma amplitude temporal que garante a existência de uma história das CNs.

Assim, concluo que a estrutura científica aqui elaborada, pessoal e efêmera, para definir o que são cidades novas deve ser pautada em seis atributos indissociáveis: o desejo em criar as CNs, a função para qual foram inicialmente idealizadas, a escolha de um sítio específico para sua implantação, o envolvimento de um profissional e o seu saber-fazer cidades, a presença de um projeto urbanístico e um tempo de criação e desenvolvimento específicos. Ao serem reunidos, tais atributos devem ser contextualizados no tempo histórico. Uma definição que permitirá aos interessados identificar as CNs - verificar sua boa ou má formação genética - e manipulá-las cientificamente segundo critérios e enfoques pré-estabelecidos, seja a partir de um ou de mais atributos inerentes ao seu DNA.

Estudiosos e pesquisadores poderão focar suas atenções sobre os empreendedores, do setor privado ou do poder público, que desejaram criar cidades visando a suprir uma vontade. Poderão se deter na multiplicidade de funções dominantes para as quais essas cidades foram empreendidas. Poderão destacar a importância da escolha de sítios estratégicos no aparecimento dessas cidades. Poderão revelar a participação da figura do urbanista (arquiteto, engenheiro civil, militar, agrônomo, agrimensor, equipes multidisciplinares etc.) na sua concepção - profissionais por vezes esquecidos ou desconhecidos dos estudos urbanísticos. Poderão ampliar o campo de pesquisa sobre a morfologia urbana, trazendo à tona os projetos, seu traçado e seu tecido. Poderão, por fim, atentar para o planejamento, a fundação e o desenvolvimento dessas cidades, tendo o tempo próprio ou o tempo histórico como foco de interesse.

Peças (atributos) de um puzzle que permite a qualquer jogador interessado jogar e definir o que é e o que não é $\mathrm{CN}$. Um jogo que não pretende ditar as únicas regras sobre o tabuleiro, mas que se mostra pioneiro ao inaugurar tal passatempo. 
Ao parafrasear Léfèbvre (1969) - No caminho, as cidades novas -, lembro que essa viagem é apenas o começo. Dessa empreitada preliminar, uma viagem sem horizontes se abre à frente deste pesquisador: um caminho a ser percorrido a fim de desvendar, aprofundar e revelar conhecimento sobre o conjunto das CNs.

Particularmente, atualmente realizo uma pesquisa mais detalhada sobre os mais de 260 exemplares brasileiros já identificados. Nesse sentido, busco atualizar a listagem com a descoberta de novos exemplares e direciono a pesquisa para uma breve avaliação caso a caso, no intuito de montar, como fizeram Lagrange e Demur (2005), uma ficha cadastral com os dados biográficos e iconográficos de cada CN. Trata-se, pois, da construção de um “Atlas de cidades novas no Brasil Republicano”, ${ }^{3}$ referência para consultas, pesquisas, análises e estudos urbanísticos (TREVISAN, 2018). Um trabalho que demandará tempo, mão de obra e dedicação por toda uma carreira, auxiliado pela colaboração de outros pesquisadores, docentes e discentes interessados.

Essas possibilidades foram aqui brevemente esboçadas mediante as dezenas de exemplares articulados ao longo da construção teórica. CNs nascidas de uma vontade, do desejo humano, caracterizadas por uma versatilidade para atender às mais diferentes funções, por uma adaptabilidade de se adequar aos sítios mais adversos, por um desenho sobre o solo ou sobre a prancheta, por um campo de ideias espaciais mesclados na cronologia de um tempo preciso.

Um quadro, que, ao ser finalizado, se revela rico e diversificado, ao mesmo tempo que único. Um mosaico colorido pelas diferentes personagens que o compõem; uma justaposição que deixa à retina a tarefa de reconstruir o tom e a imagem desejados pelo pintor, combinando as diversas impressões registradas. Uma imagem única, como fizeram os egípcios ao sintetizar a cidade e seus elementos. Uma pintura síntese exposta para definir o que são cidades novas. Um livro que deixa ao leitor a tarefa de continuar a pintar.

3 Pesquisa “Atlas de cidades novas no Brasil Republicano", sob apoio financeiro do CNPq (Bolsa de produtividade), desenvolvida no Laboratório de Estudos da Urbe (Labeurbe) da Faculdade de Arquitetura e Urbanismo da Universidade de Brasília e atrelada ao projeto "Cronologia do Pensamento Urbanístico” (http://www.cronologiadourbanismo.ufba.br/). 


\section{Referências}

AGIER, Michel. De nouvelles villes, les camps de réfugiés. Eléments d'enthologie urbaine. Annales de la recherche urbaine, França, n. 91, p. 128-136, dez. 2001.

ÁGUAS SULPHÍDRICAS E THERMAES DE SÃO PEDRO S/A. Memorial, planta e mais documentos. São Pedro: Cartório do Registro de Imóveis da Comarca de São Pedro, 08.03.1940.

AHTIK, Vito. La création des villes nouvelles. Sociologie du travail, França, ano 11, n. 4, p. 366-386, out./dez. 1969.

ALEXANDER, Christopher. Une ville n'est pas un arbre. Architecture movement continuité 1. França, n. 161, p. 3-11, nov. 1967.

ALLART, René. Le coût comparatif entre la création de villes nouvelles et l'extension de villes anciennes. Nanterre: UER de Sciences Économiques, [s.d.].

ANDRADE, Carlos Roberto Monteiro de. O plano Saturnino de Brito de Santos e a construção da cidade moderna no Brasil. Espaço e Debates - Revista de Estudos Regionais e Urbanos. São Paulo, ano 11, n. 34, p. 55-63, 1991.

ANDRADE, Carlos Roberto Monteiro de. De Viena a Santos: Camillo Sitte e Saturnino de Brito. In: SITTE, Camillo. A construção da cidade segundo seus princípios artísticos. São Paulo: Ática, 1992, ano 3, p. 206-233.

ANDRADE, C. R. M. de. Barry Parker - um arquiteto inglês na cidade de São Paulo, 1998. Tese de doutoramento - Programa de Pós-Graduação em Arquitetura e Urbanismo, Faculdade de Arquitetura e Urbanismo, Universidade de São Paulo, São Paulo, 1998. 


\section{Cidades novas}

ANDRADE, Edgar Lage de. Sertões do noroeste 1859 - 1945. São Paulo: Publicação do autor, 1945.

ANDRADE, F. de P. D. de. Subsídios para o estudo da influência da legislação na ordenação e na arquitetura das cidades brasileiras, 1966. Tese para Concurso de Cátedra (Escola Politécnica da USP) - Escola Politécnica, Universidade de São Paulo, 1966.

ARADEON, David O. Vers de villes nouvelles nigériennes projet pour Agbaja. Architecture d'Aujourd'hui, França, n. 140, p. XXXVII-XXXVIII, out./nov. 1968.

ARRUDA, E. M. Urbanização versus natureza. Requalificação socioambiental no bairro das Flores, 2009. Trabalho de Conclusão de Curso - Curso de Arquitetura e Urbanismo, Universidade Estadual de Goiás, Anápolis, 2009.

ATASH, Farhad. New towns and future urbanization in Iran. Third world planning review. Reino Unido, v. 22, n. 1, p. 67-86, fev. 2000.

ATASH, Farhad; BEHESHTIHA, Shirazi-S. New towns and their pratical challenges: the experience of Poulad Shahr in Irain. Habitat international, Reino Unido, v. 22, n. 1, p. 1-13, mar. 1998.

AYMONINO, Carlo. O significado das cidades. Lisboa: Presença, 1984 (1981).

AZEVEDO, Aroldo de. Vilas e cidades do Brasil colonial: ensaio de geografia urbana retrospectiva. Terra Livre, [S.l.], n. 10, p. 23-78, jan./jul. 1992 (orig. 1956).

BAILEY, James (Ed.). New towns in America: the design and development process. Nova York: The American Institute of Architects, 1973.

BAILLY, Antoine S. L'organisation de l'espace urbain: les villes nouvelles de l’Alberta. Revue de géographie alpie. França, n. 2, p. 261-267, 1972.

BARCELLOS, Vicente Quintella. Unidade de vizinhança: notas sobre sua origem, desenvolvimento e introdução no Brasil (2000). Disponível em: <www.unb.br/fau/ pos_graduacao/cadernos_eletronicos/unidade/ unidade.htm>. Acesso em: 14 nov. 2007. 
BARNABÉ, M. F. A contribuição do pensamento urbanístico moderno para o projeto das cidades novas do norte do Paraná. In: SEMINÁRIO SOBRE DESENHO URBANO NO BRASIL, IV, 1995, Brasília. Anais... Brasília: FAU-UnB, 1995, p. 245-260.

BARON, Louis-Pascal. Le projet de la ville nouvelle de Bang Plee: vers une politique de villes nouvelles en Thaïlande? Paris: Publicação do autor, 1992.

BATY-TORNIKIAN, Ginette (Dir.). Cités-jardins: Genèse et actualité d'une utopie. Paris: Recherches / IPRAUS, 2001.

BAUDELLE, Guy. Villeneuve d'Ascq, ville nouvelle pionnière. Pouvoirs locaux. Les cahiers de la décentralisation, França, n. 60, p. 71-74, mar. 2004.

BAUX, Jean-Pierre; SÉE, Geneviève. Naissance de l'urbanisme dans la vallée du Nil. Ivry: Serg, 1973.

BEAUJEU-GARNIER, Jacqueline et al. A propôs du deuxième colloque francosoviètique de géographie urbaine : base économique et organisation spatiale des villes soviètiques. Annales de géographie, França, n. 508, p. 730-737, nov./dez. 1982.

BECARD, Laurent. Trois cités nouvelles autour d'Agadir. Les Cahiers de l'IAURIF, França, n. 73, p. 88-106, set. 1984.

BEEVERS, Robert. The garden city utopia: a critical biography of Ebenezer Howard. Londres / Nova York: Macmillan / St. Martin’s Press, 1988.

BEHAR, Daniel; ESTEBE, Philippe; GONNARD, Sophie. Programme histoire et évaluation des villes nouvelles. Paris: Rapport Acadie, 2002.

BELLAMY, Edward. Daqui a cem anos. São Paulo: Edições Cultura, 1942 (1888).

BENCHIMOL, Samuel. El proceso de urbanización en America Latina y Venezuela, sistema de ciudades, nuevas ciudades. Inter-regional Seminar on New Towns / United Nations, Londres, 28p., jun. 1973. 
BENEVOLO, Leonardo. Diseño de la ciudad: El arte y la ciudad antigua. Barcelona: Gustavo Gili, 1977.

BENEVOLO, Leonardo. Storia della città: v. 1 La città antica. Bari: Laterza, 2006a (1976).

BENEVOLO, Leonardo. Storia della città: v. 2 La città medievale. Bari: Laterza, 2006b (1976).

BENEVOLO, Leonardo. Storia della città: v. 3 La città moderna. Bari: Laterza, 2006c (1976).

BENEVOLO, Leonardo. Storia della città: v. 4 La città contemporanea. Bari: Laterza, 2006d (1976).

BENEVOLO, Leonardo et al. Principii e forme della città. Milano: Credito Italiano, 1993.

BENSAID, Sylvie; LE JEANNIC, Thomas. Des villes-marches aux villes nouvelles: 1789-1989. Regards sur l'Île-de-France, França, n. 5, p. 13-20, nov. 1989.

BERESFORD, Maurice. New towns of middle ages: town plantation in England, Wales and Gascony. Londres: Lutterworth Press, 1967.

BERG, Max Van Der. Dutch experience, plans and visions. Cities, Reino Unido, v. 6, n. 4, p. 277-281, nov. 1989.

BERNERI, Marie Louise. Journey through utopia. Londres: Routledge / Kegan Paul, 1950.

BERNHARDT, Christoph. Laboratoires de l'état-providence industriel: les villes nouvelles en RDA. Annales de la recherché urbaine, França, n. 98, p. 127-135, out. 2005a. 
BERNHARDT, Christoph. Planning urbanization and urban growths in the socialist period: the case of East German new towns. Journal of Urban History, United States of America, v. 32, n. 1, p. 104-119, nov. 2005b.

BERTUGLIA, Cristoforo Sergio; TICH, Silvia Prodan; STANGHELLINI, Andréa. Formazione di un'identitá urbana: il caso delle villes nouvelles. Milano: Franco-Angeli, 2004.

BEST, Alan C. G.; YOUNG, Bruce S. Capitals for the homelands. Journal for geography, South Africa Republic, v. III, n. 10, p. 1043-1055, abr. 1972.

BLEYNIE, André. Les promoteurs et les villes nouvelles. Promotion immobilière, França, n. 34, p. 49-54, jan. 1977.

BLOC-DURAFFOUR, Pierre. Les villes dans le monde. Paris: Armand Colin, 1998.

BLOOM, Nicholas Dagen. Les villes nouvelles ne sont pas des banlieues: les obstacles à la planification des cités-jardins américaines. Annales de la recherché urbaine, França, n. 98, p. 167-171, out. 2005.

BOUCHER-HEDENSTRÖM, Frédérique. Vällinby, Stockholm, du modèle au musée. Annales de la recherche urbaine, França, n. 98, p. 148-152, out. 2005.

BOUCHERON, Patrick. Création urbaine et pensée humaniste dans l'Italie du Quattrocento. Actes du Colloque international de Paris "La ville au coeur du pouvoir”, Paris, v. 1, p. 261-274, 2002.

BOUMAZA, Nadir et al. Villes réelles, villes projetées: fabrication de la ville au Maghreb. Paris: Maisonneuve \& Larose, 2006.

BOYER, Jean-Marie. La programation urbaine et architecturale: L'expérience des villes nouvelles. Paris: École des Hautes Études en Sciences Sociales, 1983.

BRANCH, Melville Campbell. Common characteristics of new towns. Cities, Reino Unido, v. 1, n. 2, p. 146-149, nov. 1983. 
BRASIL. Ministério do Interior (Minter) / Serviço Federal de Habitação e Urbanismo (Serfhau). Seminário de Desenvolvimento Urbano e Local. Brasília: Minter/ Serfhau, jul. 1971.

BRASIL. Ministério do Interior (Minter) / Serviço Federal de Habitação e Urbanismo (Serfhau). Planejamento urbano e local e o desenvolvimento das faixas pioneiras. Brasília: Serfhau, 1972.

BRASIL. Ministério do Interior (Minter) / Serviço Federal de Habitação e Urbanismo (Serfhau). Controle do uso do solo urbano. Curso Intensivo de Planejamento Urbano e Local. Brasília: Serfhau/ Minter/ OEA, jun. 1973.

BRASIL. Ministério do Interior (Minter) / Serviço Federal de Habitação e Urbanismo (Serfhau). Polamazônia - Programa de pólos agropecuários e agrominerais da Amazônia. Boletim Informativo do Serfhau, Rio de Janeiro, n. 79, out. 1974.

BRASIL. Arquivo Nacional. Os presidentes e a República: Deodoro da Fonseca a Luiz Inácio Lula da Silva. Rio de Janeiro: O Arquivo, 2003.

BRAUDEL, Fernand. Écrits sur l'histoire. Paris: Flammarion, 1969.

BRUAND, Yves. Arquitetura contemporânea no Brasil. São Paulo: Perspectiva, 1991 (1981).

BUCHALLA, Anna Paula. Cidade das crianças. Veja, São Paulo, p. 79-83, 20 dez. 2000. BUENO, Beatriz Piccolotto Siqueira. Desenho e desígnio - o Brasil dos engenheiros militares. Oceanos, Lisboa, Comissão Nacional para Comemorações dos Descobrimentos Portugueses, n. 41, p. 40-58, jan./mar. 2000.

BURDETT, Richard (Ed.). Sabaudia: città nuova fascista, 1933. Londres: The Architectural Association, 1981.

CACCIAVILLANI, Carlos Alberto. La città di fondazione del nuovo continente: Il modello urbano nelle ordenanzas di Filippo II. Roma: Gangemi, 2005. 
CAIUBY, Adelardo Soares. Projecto da leprosaria modelo nos campos de Santo Ângelo: estado de São Paulo. São Paulo: Riedel, 1918.

CALABI, Donatella. Storia della città. L’età moderna. Veneza: Marsilio, 2001.

CALABI, Donatella. Storia della città. L'età contemporanea. Veneza: Marsilio, 2005.

CALABI, Donatella. Entrevista concedida ao autor. Venezia: Istituto Universitario di Architettura di Venezia, 25 mar. 2008.

CANIGGIA, Gianfranco; MALFROY, Sylvain. L'approche morphologique de la ville et du territoire. Zürich: Eidgenössische Technische Hochschule Zürich, 1986.

CANO, Wilson. Raízes da concentração industrial em São Paulo. Campinas: Instituto de Economia da Unicamp / Cromosete Gráfica e Editora, 1998.

CARDOSO, Adauto Lúcio. O urbanismo de Lucio Costa: contribuição brasileira ao concerto das nações. In: RIBEIRO, Luiz César de Queiroz; PECHMAN, Robert. Cidade, povo e nação: gênese do urbanismo moderno. Rio de Janeiro: Civilização Brasileira, 1996. Cap. 5, p. 95-122.

CARRERAS, Carles. Riera de Caldes new town: the restriction of growth. Planning outlook, Reino Unido, v. 29, n. 2, p. 63-65, 1986.

CARRIÇO, José Marques. Plano de Saturnino de Brito para Santos: urbanismo e planejamento urbano entre o discurso e a prática. In: CAMPOS, Cristina de; ATIQUE, Fernando; DANTAS, George Alexandre Ferreira (Orgs.). Profissionais, práticas e representações da construção da cidade e do território. São Paulo: Alameda, 2013, p. 141-169.

CASTEX, Jean; CELESTE, Patrick; PANERAI, Philippe. Lectures d'une ville: Versailles. Paris: Moniteur, 1980.

CERDÀ, Ildefons i Sunyer. Teoria generale dell'urbanizzazione. Milão: Jaca Book, 2004 (1867). 
CERQUEIRA, H. O plano e prática na construção de Palma, 1998. Dissertação de mestrado - Instituto de Pesquisa e Planejamento Urbano e Regional, Universidade Federal do Rio de Janeiro, Rio de Janeiro, 1998.

CERTEAU, Michel de. A invenção do cotidiano: artes de fazer. Petrópolis: Vozes, 1996 (1980).

CERVEO, Robert. Sustainable new towns, Stockholm's rail-served satellites. Cities, Reino Unido, v. 12, n. 1, p. 41-45, fev. 1995.

CHALINE, Claude. Les villes nouvelles dans le monde. Paris: Presses universitaires de France, 1985.

CHASSEL, Francis (Dir.). De l'art urbain à l'urbanisme: villes nouvelles, cites satellites, colonies. Les cahiers de la recherché architecturale, França, n. 9, 91p., jan. 1982.

CHATIN, Catherine; DOUBLET, Maurice. Neuf villes nouvelles: une expérience française d’urbanisme. Paris: Dunod, 1975.

CHOAY, Françoise. Ville nouvelle. Le Débat, França, n. 50, p. 224-225, mai./ago. 1988.

CHOAY, Françoise. O urbanismo: utopias e realidades, uma antologia. São Paulo: Perspectiva, 1997 (1965).

CHOAY, Françoise; MERLIN, Pierre. A propos de la morphologie urbaine. Noisyle-Grand: Laboratoire Théorie des Mutations Urbaines en Pays Développés, 1986, 2v. CHOAY, Françoise; MERLIN, Pierre. Dictionnaire de l'urbanisme et de l'aménagement. Paris: Presses Universitaires de Paris, 2005.

CLAPSON, Mark. Invincible green suburbs, brave new towns: social change and urban dispersal in postwar England. Manchester: Manchester University Press, 1998. 
CLAUDE, Viviane. Les equipes d'aménagement des villes nouvelles: avatars d'une expérience collective nationale. Annales de la recherche urbaine, França, n. 98, p. 15-24, out. 2005.

CLAVAL, Paul. De Haussmann au musée social. In: BERDOULAY, Vincent; CLAVAL, Paul (Dirs.). Aux débuts de l'urbanisme français: regards croisés de scientifiques et de profissionnels (fin XIXe - début XXe siècle). Paris: L’Harmattan, 2001.

COHEN, Jean-Louis. Entrevista concedida ao autor. Paris: Grand Arche de la Défense, 18 set. 2008.

CONSTANDSE, A. K.; GALANTAY, Erwin Y.; OHBA, T. (Eds.). New towns world-wide. The Hague: International Federation for Housing and Planning, 1985.

CORSINI, José Maria Ordeig. Diseño urbano y pensamiento contemporáneo. Barcelona: Monsa, 2004.

COSTA, Maria Elisa. Entrevista concedida ao autor. Le Havre: Mairie, 13 set. 2007. COULON, Alain. Les villes nouvelles et le projet urbain. Saint-Quentin-en-Yvelines. Cahiers de la recherche architecturale. França, n. 32-33, p. 89-102, 1993.

CREESE, Walter. The search for environment: the garden city before and after. New Haven / Conn: M.I.T. Press, 1992.

CULLEN, Gordon. Paisagem urbana. Lisboa: Edições 70, 2004 (1971).

D’ARC, Hélène Riviere; SCHNEIER, Graciela. Activités informelles et espace: les cas des villes nouvelles de ciudad Guayana (Venezuela) et Camaçari (Brésil). Revue Tiers Monde, França, n. 95, p. 653-667, jul./set. 1983.

DAEWOO CORPORATION. New town development in Korea. Seul: DAEWOO Corporation, 1998.

DANGER, René. Cours d'urbanisme (Technique des plans d'aménagement de villes). Paris: L. Eyrolles, 1933. 
DEFFONTAINES, Pierre. Como se constituiu no Brasil a rede de cidades. Boletim Geográfico, Rio de Janeiro, ano 2, n. 14, 1944.

DEL RIO, Vicente. Introdução ao desenho urbano no processo de planejamento. Rio de Janeiro: Pini, 1990.

DELAFONS, John. Old new towns. Town and country planning, Reino Unido, v. 68, n. 11, p. 340-342, nov. 1999.

DELSON, Roberta Marx. Novas vilas para o Brasil-Colônia: Planejamento espacial e social no século XVIII. Brasília: Alva, 1997 (1979).

DIEBOLD, Marie-Claude; LEMONIER, Marc. Villes nouvelles. Diagonal, França, n. 149, p. 10-14, mai./jun. 2001.

DOXIADIS ASSOCIATES INTERNATIONAL. Three new cities in Africa. Doxiadis associates review. Grécia, v. 7, n. 78, 30p., out. 1971.

DOXIADIS, Constantinos Apostolou et al. New towns in the 1970s. Ekistics. Grécia, v. 36, n. 212, 72p., jul. 1973.

DUCON, Estelle; YOKOHARI, Makoto. L'involution et urbaine dans l'aire tokyoïte: le déclin de la ville nouvelle de Tama. Annales de la recherche urbaine, França, n. 100, p. 23-27, 2006.

DULY, Colin. The houses of mankind. Londres: Thames and Hudson Ltd., 1979.

DUMSDAY, Jim (Ed.). New towns issue. Town and country planning, Reino Unido, v. 53, n. 11, p. 294-331, nov. 1984.

EDEN, Joseph A.; ALANEN, Arnold R. Looking backward at new deal town: Greendale, Wisconsin, 1935-1980. Journal of the American Planning Association, United States of America, v. 49, n. 1, p. 40-58, 1983.

EFRAT, Elisha. New development towns in Israel (1948-1993). Cities, Reino Unido, v. 11, n. 4, p. 247-252, ago. 1994. 
EGYPT. Organization for New Communities. New communities in Egypt: Twenty years of development 1976-1996. Cairo: Ministry of Housing, Utilities and Urban Communities, 1996.

ENG, Teo Siew. Character and identity in Singapore new towns: planner and resident perspectives. Habitat international. Reino Unido, v. 20, n. 2, p. 279-294, jun. 1996.

EVENO, Emmanuel (Ed.). Utopies urbaines. Toulouse: Presses Universitaires du Mirail, 1998.

FACHARD, Sabine. Villes nouvelles et expérimentation sociale. PCM, França, n. 1, p. 37-40, jan. 1982.

FELICIANO, M. M. Resgate histórico do leprosário Asylo Colônia Santo Ângelo, 2008. Dissertação de mestrado - Pontifícia Universidade Católica, São Paulo, 2008.

FERRARI, Celson. Dicionário de urbanismo. São Paulo: Disal, 2004.

FICHER, Sylvia. Os arquitetos da Poli: Ensino e profissão em São Paulo. São Paulo: Fapesp / Edusp, 2005.

FICHER, Sylvia; PALAZZO, Pedro Paulo. Os paradigmas urbanísticos de Brasília. Cadernos PPGAU-FAUFBA, Salvador, PPG-AU / FAUFBA, ano 3, edição especial, p. 49-71, 2005.

FIRMAN, Tommy. New town development in Jakarta Metropolitan Region: a perspective of spatial segregation. Habitat international. Reino Unido, v. 28, n. 3, p. 349-368, set. 2004.

FLORIN, Bénédicte. Planification et compétences citadines dans les villes nouvelles égyptiennes. Villes en parallèle, França, n. 32-33-34, p. 227-235, dez. 2001.

FRANCE. Direction Régionale de L’Équipement. Groupe Central des Villes Nouvelles (Org.). Choix des concepteurs en villes nouvelles. Paris: SGVN, 1980. 
FRANCE. Ministère de la Culture; Ministère de l’Équipement. Programme interministériel d'histoire et d'évaluation des villes nouvelles françaises. Paris: Ministère de la Culture, 2007.

FRANCE. Secrétariat des Missions d’Urbanisme et d'Habitat. Villes nouvelles au site obligé: Monographie sur la création de Gamba. Paris: SMUH, 1970a.

FRANCE. Secrétariat des Missions d'Urbanisme et d'Habitat. Villes nouvelles au site obligé: Monographie sur la création de Malbaza. Paris: SMUH, 1970b.

FRANCE. Secrétariat des Missions d’Urbanisme et d'Habitat. Villes nouvelles au site obligé: Monographie sur la ville de Figuil. Paris: SMUH, 1975.

FREITAG, B. Utopias urbanas. In: ENCONTRO DA SOCIEDADE BRASILEIRA DE SOCIOLOGIA, X, 2001, Fortaleza. Anais... Fortaleza, set. 2001.

FRIDMAN, Fania. Breve história do debate sobre a cidade colonial brasileira. In: PINHEIRO, Eloísa Petti; GOMES, Marco Aurélio A. de Filgueiras (Orgs.). A cidade como história: os arquitetos e a historiografia da cidade e do urbanismo. Salvador: EDUFBA / PPGAU-FAUFBA, 2005, p. 43-72.

GEDDES, Patrick. Cidades em evolução. Campinas: Papirus, 1994 (1915).

GÉRARD, Michel. Les villes nouvelles au site détermine. Planification habitat information, França, n. 89, p. 13-62, nov. 1977.

GHANA. Town and Country Planning Department. New towns in Ghana. Inter-regional Seminar on New Towns / United Nations, Londres, 6p., 4-19 jun. 1973.

GIORDANO, Pier Luigi. L'idea della Città Giardino. Bolonha: Calderini Bologna, 1962.

GOLANY, Gideon. New-town planning: principles and practice. Nova York: Wiley, 1976. 
GORDON, David L. A. (Ed.). Planning twentieth century capital cities. Nova York: Routledge, 2006.

GRUPO DE PESQUISA EM HABITAÇÃO E URBANISMO (HabUrb). Planos para cidades novas planejadas: estâncias balneárias e cidades de relocação. São Carlos: IAU-USP, 2003.

GUEDES, Joaquim. Monumentalidade x cotidiano: a função pública da arquitetura. Revista Mínimo Denominador Comum, Brasília, ano I, n. 3, mar. 2006.

GUIMARÃES, Berenice Martins. A concepção e o projeto de Belo Horizonte: a utopia de Aarão Reis. In: RIBEIRO, Luiz César de Queiroz; PECHMAN, Robert. Cidade, povo e nação: gênese do urbanismo moderno. Rio de Janeiro: Civilização Brasileira, 1996. Cap. 6, p. 123-140.

GUIMARÃES, Pedro Paulino. Configuração urbana: evolução, avaliação, planejamento e urbanização. São Paulo: ProLivros, 2004.

GUPTA, R. C. Urbanization and the new towns. Journal of the Institute of Town Planners. India, n. 115, p. 4-14, nov. 1983.

GUYARD, Jacques. Villes nouvelles... l’âge ingrat. Communes de France, França, n. 188, p. 25-33, jun./jul. 1980.

GUYARD, Jacques. Le projet de loi sur les villes nouvelles. Bulletin d'information de l'association française des villes nouvelles, França, n. 1, 4p., dez. 1982.

HALL, Peter (Ed.). New towns revisited. Built environment, Reino Unido, v. 9, n. 3-4, p. 165-277, 1983.

HALL, Peter. Cidades do amanhã. São Paulo: Perspectiva, 1995 (1988).

HALL, Peter. 1946 - 1996: from new town to sustainable social city. Town and country planning, Reino Unido, v. 65, n. 11, p. 295-297, nov. 1996. 
HAMER, David. Town planning in new cities in the nineteenth century: a comparative perspective. Planning perspectives. Reino Unido, v. 9, n. 2, p. 125-137, abr. 1994.

HAUMONT, Nicole. Les villes nouvelles d'Europe à la fin du 20ème siècle: Recherche comparative internationale. Tome I, Hongrie - Pologne. Tome II, Ecosse - France. Paris: CRH, 1997a, 2v.

HAUMONT, Nicole (Dir.). Les villes nouvelles françaises. Nanterre: CRH, 1997b.

HAUMONT, Nicole et al. Villes nouvelles et villes traditionelles: Une comparaison internationale. Paris: l’Harmattan, 1999.

HELAND, Laure. Albertslund, une ville toujours nouvelle: du volontarisme urbanistique à l'innovation environnementale. Annales de la recherché urbaine, França, n. 98, p. 141-147, out. 2005.

HERINGTON, John. Changing ideas on private new towns. Town and country planning. Reino Unido, v. 57, n. 11, p. 308-309, nov. 1988.

HOLANDA, Frederico de. Urbanidade, o resgate: Nova Iorque, MA. In: HOLANDA, Frederico de (Org.). Arquitetura \& Urbanidade. São Paulo: ProEditores, 2003, p. 100-113.

HOWARD, Ebenezer. Cidades-jardins de amanhã. São Paulo: Hucitec, 1996 (1898).

HUI, Eddie C.M.; LAM, Manfred C.M. A study of commuting patterns of new town residence in Hong Kong. Habitat international. Reino Unido, v. 29, n. 3, p. 421-437, set. 2005.

HUNGARY. Magyar Urbanisztikai Tarsasag. New towns in Hungary. The Hague: INTA / AIVN, 1984.

HUOT, Jean-Louis (Dir.). La ville neuve, une idée de l'antiquité? Paris: Errance, 1988. IGI, Jitsunobi. Pereira Barreto: a cidade que vi nascer. Pereira Barreto: Publicação de Autor, 1978. 
INTERNATIONAL NEW TOWNS INSTITUTE - INTI. Disponível em: <http:// www.newtowninstitute.org/>. Acesso em: 13 jan. 2009.

IRAN. Ministry of Development and Housing. A report of the studies to establishment on new cities in Iran. Tehran: New cities development corporation, 1991.

JOSSIFORT, Sabine. L’aménagement de la région metropolitaine du Caire: La contribuition des villes nouvelles et des new settlements du désert. Paris: Publicação da Autora, 1998.

JOSSIFORT, Sabine. Les villes nouvelles d’Algérie. Urbanisme, França, n. 311, p. 24-29, mar./abr. 2000.

KAMBO, B. D. New industrial towns in India and their regional impact. Plan East Africa, Kenya, v. II, n. 5, p. 40-44, set./out. 1971.

KHAMAISI, Rassem. Building new towns in the formation of new state of Palestine. Third world planning review, Reino Unido, v. 20, n. 3, p. 285-308, 1998.

KOPP, Anatole. Changer la vie, changer la ville. Paris: Colection 10/18, 1975.

KOSTOF, Spiro. The city shaped: urban patterns and meanings through history. Londres: Thames \& Hudson, 1999 (1991).

KRUFT, Hanno-Walter. Le città utopiche: La città ideale dal XV al XVIII secolo fra utopia e realtà. Bari: Laterza, 1990.

LACAZE, Jean-Paul. Villes nouvelles: l'exemple du Vaudreuil. PCM Le Pont, França, n. 3, p. 35-39, mar. 1994.

LACONTE, Pierre et al. Villes nouvelles à l'étranger. Urbanisme. França, n. 190191, p. 107-119, jul. 1982.

LAGRANGE, Martine; DERNUR, Cécile. Mémoires audiovisuelles des villes nouvelles françaises. Paris: Centre Audiovisuel de Paris, 2005. 
LAMAS, José Manuel Ressano Garcia. Morfologia urbana e desenho da cidade. Lisboa: Fundação Calouste Gulbenkian, 2000 (1993).

LANG, Susan. The ideal city: from Plato to Howard. The Architectural Review, Reino Unido, v. 112, n. 668, p. 91-101, ago. 1952.

LAVEDAN, Pierre. Géographie des villes. Paris: Gallimard, 1936.

LAVEDAN, Pierre. Histoire de l'urbanisme. Paris: Henri Laurens, 1952 (1926).

LE CORBUSIER. A carta de Atenas. São Paulo: Hucitec, 1993 (1933).

LEE, Chang-Moo; AHN, Kun-Hyuck. Five new towns in the Seoul metropolitan area and their attractions in non-working trips: implications on self-containment of new towns. Habitat International, Reino Unido, v. 29, n. 4, p. 647-666, dez. 2005.

LEFEBVRE, Henri. O direito à cidade. São Paulo: Moraes, 1991 (1969).

LELOUP, Gilles. L'exportation des villes nouvelles dans les pays du tiers monde: une arme supplémentaire au service du développement? Crédit foncier magazine. França, n. 174, p. 30-36, jan./fev. 1983.

LEME, Maria Cristina da Silva (Org.). Urbanismo no Brasil, 1895-1965. Salvador: EDUFBA, 2005 (1999).

LÉVI-STRAUSS, Claude. O pensamento selvagem. Campinas: Papirus, 2002 (1962).

LEVY, Albert. La qualité de la forme urbaine: problématique et enjeux. Paris: Laboratoire TMU / Institut Français d’Urbanisme, 1992.

LISPECTOR, Clarice. A descoberta do mundo. Rio de Janeiro: Nova Fronteira, 1984.

LLOYD, Greg. The scottish new towns. Town and country planning, Reino Unido, v. 58, n. 11, p. 302-311, nov. 1989.

LOEVENBRUCK, Jean-Paul. Les villes nouvelles américaines. Bulletin d'information de l'association française des villes nouvelles, França, n. 12, p. I-IV, dez. 1986. 
MACIEL, D. P. Goiânia (1933-1963): Estado e Capital na produção da cidade, 1996. Tese de doutoramento - Instituto de Ciências Humanas e Filosofia, Universidade Federal Fluminense, Niterói, 1996.

MALISZ, Boleslaw. La Pologne construit des villes nouvelles. Varsovie: Éditions Polonia, 1961.

MAMOLI, Marcello; TREBBI, Giorgio. Storia dell'urbanistica: L'Europa del secondo dopoguerra. Bari: Laterza, 1988.

MANSO, Celina Fernandes Almeida. Goiânia: uma concepção urbana, moderna e contemporânea - um certo olhar. Goiânia: Publicação do autor, 2001.

MARINO, C. E. C. Ócio e Lazer em São Paulo da Belle Époque. A vilegiatura marítima e a invenção do Guarujá enquanto balneário da metrópole (1890-1915). In: ENCONTRO NACIONAL DA ANPUR, XVII, 2017. Anais... São Paulo: ANPUR, 2017.

MARQUES, Jarbas Silva. Bernardo Sayão - o último pioneiro. Disponível em: < http://www.ueg.br/noticia/37604 >. Acesso em: 01 abr. 2018.

MARTIN, Frank Edgerton. American civic art. Landscape architecture, United States of America, v. 89, n. 11, p. 64-79, nov. 1999.

MARX, Murillo. Cidade brasileira. São Paulo: Melhoramentos / Edusp, 1980.

MASCARÓ, Juan Luis. Loteamentos urbanos. Porto Alegre: Publicação do autor, 2003.

MATHIEU, Márcia Regina de Andrade. Entrevista concedida ao autor. Paris: Institut de Recherche pour le Développement, 18 set. 2008.

MAUMI, Catherine. Thomas Jefferson et le projet du nouveau monde. Paris: Éditions de la Villette, 2007.

MEDEIROS, Ethel Bauzer. O lazer no planejamento urbano. Rio de Janeiro: Fundação Getúlio Vargas. 1971. 
MERLIN, Pierre. Les villes nouvelles. Paris: Press Universitaires de France, 1969a.

MERLIN, Pierre. Les villes nouvelles en France et à l'étranger. Le Vaudreuil: Mission d'études de Vaudreuil, 1969b.

MERLIN, Pierre. Urbanisme et villes nouvelles en Union Soviétique. Cahiers de I'IAURP, França, v. 38, 99p., mar. 1975.

MERLIN, Pierre. Aménagement regional et urbain et villes nouvelles au Japon. Les cahiers de l'IAURIF, França, v. 44, 95p., dez. 1976.

MERLIN, Pierre. Quelles leçons peut-on tirer des experiences des villes nouvelles des autres pays? Tehran: [s.n.], 1977.

MERLIN, Pierre. Morphologie urbaine et parcellaire. Saint Dennis: Presses Universitaires de Vincennes, 1988.

MERLIN, Pierre. Les villes nouvelles en France. Paris: PUF, 1991.

MERLIN, Pierre. Les villes nouvelles de l'ex-URSS. Lettre des villes nouvelles. França, n. 23, p. 7-9, 1992.

MERLIN, Pierre; GELY, Mireille. Bibliographie sur les villes nouvelles française. Paris: Institut Français d’Urbanisme, 1989.

MERLIN, Pierre; GUERTIN, Pierre. Villes nouvelles en Scandinavie. Cahiers de I'IAURP, França, v. 9, 64p., out. 1967.

MERLIN, Pierre; SUDARSKIS, Michel. From garden cities to urban reconstruction: new towns in perspective. The Hague: INTA / AIVN, 1991.

MING, Huang-Xiang. One city, nine towns. Alla ricerca di periferie ideali in China. Urbanistica, Italia, n. 122, p. 75-81, set./dez. 2003.

MITCHELL, William J. E-topia: A vida urbana - mas não como a conhecemos. São Paulo: SENAC, 2002. 
MITTELBACH, Frank G. New cities in developed and developing nations. Los Angeles: University of California, 1973.

MONBEIG, Pierre. Pioneiros e fazendeiros de São Paulo. São Paulo: Hucitec, 1984 (1949).

MONTAGU, Alain; SOKOLSKY, Serge. Villes nouvelles: villes innovantes? Paris: SGVN, 1995.

MONTEIRO, Maurílio de Abreu. A ICOMI no Amapá: meio século de exploração mineral. Novos cadernos NAEA, Belém, v. 6, n. 2, p. 113-168, dez. 2003.

MORAES, Lúcia Maria. A segregação planejada: Goiânia, Brasília e Palmas. Goiânia: EDUCG, 2003.

MORRIS, Anthony Edwin Jones. Historia de la forma urbana: Desde sus orígenes hasta la Revolución Industrial. Barcelona: GG, 2001 (1979).

MOUSSA, A. Problèmes particuliers à la création des villes nouvelles en Afrique. Paris: Institut d'Urbanisme, 1972.

MUMFORD, Lewis. Storia dell'utopia. Bolonha: Calderini Bologna, 1969.

MUMFORD, Lewis. La città nella storia. Urbanistica informazioni. Italia, n. 122, p. 28-32, mar./abr. 1992.

MUMFORD, Lewis. A cidade na história: suas origens, transformações e perspectivas. São Paulo: Martins Fontes, 1998 (1961).

MURARD, Lion; FOURQUET, François. La naissance des villes nouvelles: Anatomie d'une décision (1961-1969). Paris: Presses des Ponts et Chaussées, 2004.

MURATORI, Saverio. Studi per uma operante storia urbana di Venezia. Roma: Istituto Poligrafico dello Stato, 1960. 
NARDIN, Henri; MERLIN, Pierre; RICHARD, Maurice. Les villes nouvelles aux U.S.A. Paris: IAURP, 1968.

NARDIN, Henri; MERLIN, Pierre; RICHARD, Maurice. Urbanisme aux U.S.A. Villes nouvelles. Cahiers de l'IAURP, França, v. 15, p. 35-62, mai. 1969.

NEIVA, Arthur H. Getúlio Vargas e o problema da imigração e da colonização. Revista de Imigração e Colonização, Rio de Janeiro, ano 3, n. 1, abr. 1942.

NIHLÉN, Mats. Une ville entière condamnée à déménager. Courrier international, França, n. 880, p. 48, set. 2007.

OLIVEIRA, A. C. X. de. De Uruk à Villa Hadriana: Contribuição ao estudo da urbanização na Antiguidade (relações entre espaços de uso público, privado, coletivo e restrito), 2007. Tese de doutoramento - Programa de Pós-Graduação em Arquitetura e Urbanismo, Faculdade de Arquitetura e Urbanismo, Universidade de São Paulo, São Paulo, 2007.

OLIVEIRA, Francisco de. O estado e o urbano no Brasil. Revista Espaço \& Debates - Estudos Regionais e Urbanos. São Paulo, n. 6, p. 36-54, jun./set. 1982.

OSBORN, Frederic James; WHITTICK, Arnold. New towns: Their origins, achievements and progress. Londres: Leonard Hill, 1977.

ÔTTI, Fritz; SZUCSITS, Regina; PICHLER, Irene. Neue städte. Villes nouvelles. Planung und realitat. Plan et réalité. Beitrage zu stadtebau und raumplanung. Austria, n. 23, 125p., out. 1996.

PANERAI, Philippe. L'étude pratique des plans de villes. Villes en parallèle, Paris, Université Paris X-Nanterre / Laboratoire de Géographie Urbaine, n. 12-13, p. 100-109, nov. 1988.

PANERAI, Philippe. Análise urbana. Brasília: EDUNB, 2006 (1999).

PANERAI, Philippe. Entrevista concedida ao autor. Paris: bureau d'urbaniste, 21 set. 2007. 
PANERAI, Philippe et al. Les Bastides, d'Aquitaine, du Bas-Languedoc et du Béaru: Essai sur la regularité. Brussel: Archives d'architecture moderne, 1985.

PANERAI, Philippe; CASTEX, Jean; DEPAULE, Jean-Charles. Formes urbaines: de l'îlot à la barre. Marselha: Parenthèses, 1997.

PANERAI, Philippe; GENDRE, Bernard; CHATELET, Anne-Marie. Villes neuves et villes nouvelles: Les composantes rationnelles de l'urbanisme français. Versalhes: École d'Architecture, 1986.

PANERAI, Philippe; MANGIN, David. Projet urbain. Marselha: Parenthèses, 1999. PAQUOT, Thierry; PAQUOT, Elisabeth. Villes nouvelles: une utopie de droite. Espaces et sociétés, França, n. 22-23, p. 3-23, dez. 1977.

PEETS, Elbert; HEGEMANN, Werner. The American Vitruvius: an architects' handbook of civic art. Nova York: Princeton Architectural Press, 1988 (1922).

PELLEGRINI, Giorgio (Org.). Città di fondazione italiane: 1928-1942. Latina: Novecento, 2006.

PELLETIER, Jean; DELFANTE, Charles. Villes et urbanisme dans le monde. Paris: Armand Colin, 2000.

PENNA, José Osvaldo de Meira. Quando mudam as capitais. Rio de Janeiro: IBGE, 1958.

PERLOFF, Harvey S. New towns in-town. Journal of the American Institute of Planners, [s.l.], v. 32, p. 155-162, 1966.

PEROTE, L. T. R. Jaguaribara: a cidade submersa. História de uma cidade planejada no sertão do Ceará, 2006. Dissertação de mestrado - Programa de PósGraduação, Faculdade de Arquitetura e Urbanismo, Pontifícia Universidade Católica de Campinas, Campinas, 2006. 
PESSOA, Denise Falcão. Utopia e cidades: proposições. São Paulo: Annablume / Fapesp, 2006.

PETIT, Olivier. L'influence des villes nouvelles françaises en Asie, dans leur rapport avec les idées, les entreprises et les hommes de l'art français. Paris: METL / DGUHC, 2002.

PHILLIPS, David R.; YEH, Anthony G. O. (Eds.). New towns in East and Southeast Asia: Planning and development. Hong-Kong: Oxford University Press, 1987.

PICCINATO, Luigi. La progettazione urbanistica: La città come organismo. Venezia: Marsilio, 1988.

PINHEIRO, Eloísa Petti; GOMES, Marco Aurélio A. de Filgueiras (Orgs.). A cidade como história: Os arquitetos e a historiografia da cidade e do urbanismo. Salvador: EDUFBA / PPGAU-FAUFBA, 2005.

PIZZI, Donata. Città Nuove: innovazione e idealità nella città de fondazione. Milano: Skira, 2004.

POITEVIN, Jackie; ETTEINGER, Bernard; ANTIER, Gilles. Voie étroite pour villes nouvelles. Cahiers de l'IAURIF, França, n. 104-105, p. 189-204, ago. 1993.

PORTOGHESI, Paolo. Dizionario enciclopedico di architettura e urbanistica. Roma: Istituto Editoriale Romano, 1969, 6v.

POTTER, Stephen. New towns around the world. Town and country planning. Reino Unido, v. 56, n. 11, p. 289-293, nov. 1987.

PRAKASH, Ved. New towns in India. Detroit: The Cellar Book Shop, 1969.

PRINZ, Dieter. Urbanismo 1: projeto urbano. Lisboa: Presença, 1980.

PURDON, Charles Benjamim. The building of satellite towns. Londres: J.M. Dent \& Sons Ltd., 1925. 
QUERRIEN, Anne; LASSAVE, Pierre. Les visages de la ville nouvelle. Annales de la recherche urbaine, França, n. 98, p. 3-5, out. 2005.

RAGON, Michel. L’urbanisme et la cité. Paris: Hachette, 1964.

RAGON, Michel. Les cités de l'avenir. Paris: Planète, 1967.

RAYMOND, Jean. Précis d'urbanisme moderne. Paris: Dunod, 1934.

REGO, Renato Leão. As cidades plantadas: os britânicos e a construção da paisagem do norte do Paraná. Londrina: Humanidades, 2009.

REIS FILHO, Nestor Goulart. São Paulo e outras cidades: produção social e degradação dos espaços urbanos. São Paulo: Hucitec, 1994.

REIS FILHO, Nestor Goulart. Evolução urbana no Brasil (1500/1720). São Paulo: Pini, 2000a (1968).

REIS FILHO, Nestor Goulart. Imagens de vilas e cidades do Brasil colonial. São Paulo: CNPq / Fapesp / Iphan, 2000b.

REVISTA L'ARCHITECTURE D’AUJOURD’HUI. Villes nouvelles, França, n. 146, out./nov. 1969.

REVISTA AU. Planeta Amazônia. São Paulo: Pini, ano 3, n. 10, fev./mar. 1987.

REVISTA MÓDULO. Cidade de São Bento da Lagoa: projeto de urbanização da Restinga de Maricá. Rio de Janeiro, n. 40, p. 64-71, set. 1975.

RIBEIRO, Luiz César de Queiroz; PECHMAN, Robert (Orgs.). Cidade, povo e nação: gênese do urbanismo moderno. Rio de Janeiro: Civilização Brasileira, 1996.

RIBEIRO, M. A. R. História sem fim: inventário da saúde pública São Paulo 18801930, 1991. Tese de doutoramento - Instituto de Economia, Universidade Estadual de Campinas, Campinas, 1991. 
RISSELADA, Max; HEUVEL, Dirk Van Der (Eds.). Team 10, 1953-81: In search of utopia of the present. Roterdã: NAi Publishers, 2005.

RODRIGUES, A. A. B. Águas de São Pedro - estância paulista: Uma contribuição à geografia de recreação, 1985. Tese de doutoramento - Faculdade de Filosofia, Letras e Ciências Humanas, Universidade de São Paulo, São Paulo, 1985.

ROGERS, Richard. Cidades para um pequeno planeta. Barcelona: Gustavo Gili, 2001. ROSSI, Aldo. L’Architecture de la ville. Paris: L’Équerre, 1981.

ROUAT, Sylvie. Les nouvelles villes flottantes. Sciences et avenir, França, n. 595, p. 60-63, set. 1996.

ROUILLARD, Dominique. L'utopie contemporaine. In: BURDESE, Jean-Claude et al. De la ville à la mégapole: essor ou déclin des villes au XXIème siècle? Paris / La Défense: DRAST, 1998, p. 119-125.

ROULEAU, Bernard. Villages et faubourgs de l'ancien Paris: Histoire d'un espace urbain. Paris: Seuil, 1985.

ROULLIER, Jean-Eudes. Regards sur les villes nouvelles. Pouvoirs locaux. Les cahiers de la décentralisation, França, n. 60, p. 24-30, mar. 2004.

RUSHMAN, Gordon. Towards new cities in Australia. Town planning review, Reino Unido, v. 47, n. 1, p. 4-25, jan. 1976.

RYKWERT, Joseph. The idea of a town: the anthropology of urban form in Rome, Italy and The Ancient World. Massachusetts: The MIT Press, 1988 (1976).

RYKWERT, Joseph. A sedução do lugar: A história e o futuro da cidade. São Paulo: Martins Fontes, 2004.

SÁ, Cristina Cunha da Costa e. Formas e símbolos em aldeias indígenas brasileiras. Projeto, São Paulo, n. 57, p. 51-56, nov. 1983. 
SAFIER, Michaël. Le rôle des villes nouvelles dans l'urbanisation. Planification habitat information, França, n. 89, p. 3-12, nov. 1977.

SALLEH, Ghani B.; CHOGUILL, Charles L. New towns in rural regions: a case study from Malaysia. Cities, Reino Unido, v. 9, n. 2, p. 138-149, mai. 1992.

SAMONÀ, Giuseppe. L’urbanistica e l'avvenire della città. Bari: Laterza, 1985 (1959).

SANDERS, Spencer Edward; RABUCK, Arthur Jacob. New city patterns: the analysis of and a technique for urban reintegration. Nova York: Reinhold Publishing Corp, 1946.

SANTOS, Carlos Nelson Ferreira dos. A cidade como um jogo de cartas. Rio de Janeiro / São Paulo: EDUFF / Projeto, 1988.

SANTOS, Paulo Ferreira. Formação de cidades no Brasil colonial. Rio de Janeiro: EDUFRJ, 2001 (1968).

SEGAWA, Hugo. Palmas, cidade nova ou apenas uma nova cidade? Projeto, São Paulo, n. 146, p. 94-109, 1991.

SEGAWA, Hugo; DOURADO, Guilherme Mazza. Oswaldo Arthur Bratke. São Paulo: ProEditores, 1997.

SHOSTAK, Lee; LOCK, David. New country towns in the South East: a planned response to a regional crisis. The Planner, Reino Unido, v. 71, n. 5, p. 19-22, mai. 1985.

SICA, Paolo. Historia del urbanismo. Madrid: Instituto de Estudios de Administración Local, 1981.

SINGER, Paul. Economia política da urbanização. São Paulo: Brasiliense / CEBRAP, 1973.

SITTE, Camillo. A construção da cidade segundo seus princípios artísticos. São Paulo: Ática, 1992 (1889).

SMADJA, Gilbert. L'innovation en villes nouvelles. Bulletin d'information de l'association française des villes nouvelles, França, n. 13, p. I-IV, abr. 1987. 
SMADJA, Gilbert. Art et espace public: le point sur une demarche urbaine. Paris / La Défense: CGPC, 2003.

SMITH, Robert C. Urbanismo colonial no Brasil. Bem Estar, [s.l.], n. 1, fev./mar. 1958.

SOUZA, Marcelo Lopes de. Mudar a cidade: uma introdução crítica ao planejamento e à gestão urbanos. Rio de Janeiro: Bertrand Brasil, 2001.

SPIEGEL, Erika. New towns in Israel: urban and regional planning and development (Neue Städte in Israel. Städtische und regionale planung und entwicklung). Stuttgart: Karl Krämer Verlag, 1966.

STEIN, Clarence Samuel. Toward new towns for America. Massachusetts: The MIT Press, 1989 (1957).

STEINKE, R. Ruas curvas versus ruas retas: Na história das cidades, três projetos do eng. Jorge de Macedo Vieira, 2002. Dissertação de mestrado - Programa de Pós-Graduação em Arquitetura e Urbanismo, Instituto de Arquitetura e Urbanismo, Universidade de São Paulo, São Carlos, 2002.

SUDOUR, Laure. Les villes nouvelles devant leur avenir. Études, França, t. 366, n. 1, p. 29-43, jan. 1987.

TAFURI, Manfredo. La esfera y el laberinto: vanguardias y arquitectura de Piranesi a los años setenta. Barcelona: Gustavo Gili, 1984.

TAVARES, Jeferson Cristiano. Projetos para Brasília 1927-1957. Brasília: Iphan, 2014.

THOMAS, Wyndham et al. New towns in transition. Town and country planning, Reino Unido, v. 51, n. 10, p. 265-295, nov. 1982.

TILLIETTE, Bruno (Dir.). Un nouvel art de ville: Huit villes nouvelles en quête d'elles-mêmes. Paris: Autrement, 1985.

TOULAN, Nohad A. (Dir.). New towns in the Greater Cairo urban region regional study. Cairo: Gopp, 1979-1980, 2v. 
TREVISAN, R. Incorporação do ideário da Garden-City inglesa na urbanística moderna brasileira: Águas de São Pedro, 2003. Dissertação de mestrado - Programa de Pós-Graduação em Engenharia Urbana, Universidade Federal de São Carlos, São Carlos, 2003.

TREVISAN, Ricardo. Pensar por atlas. In: JACQUES, Paola Berenstein; PEREIRA, Margareth da Silva (Orgs.). Nebulosas do Pensamento Urbanístico: tomo I - modos de pensar. Salvador: EDUFBA, 2018, p. 46-69.

TREVISAN, R.; FICHER, S.; MATTOS, F.M. de. Brasil: um século, cinco cidades novas administrativas. In: ENCONTRO NACIONAL DA ANPUR, XVII, 2017. Anais... São Paulo: ANPUR, 2017.

TRINDADE, D. O desenho urbano de Palmas, 1999. Dissertação de mestrado Programa de Pós-Graduação em Arquitetura e Urbanismo, Instituto de Arquitetura e Urbanismo, Universidade de São Paulo, São Carlos, 1999.

TSIOMIS, Yannis. O ensino do projeto urbano entre a crise e a mutação. In: MACHADO, Denise Barcellos Pinheiro (Org.). Sobre urbanismo. Rio de Janeiro: Viana \& Mosley / PROURB, 2006, p. 65-79.

TURNER, Alan; SMULIAN, Jonathan. New cities in Venezuela. In: DWYER, Denis John (Ed.). The city in the third world. Londres: Macmillan, 1974.

UNDERHILL, Jack. New communities: A selected bibliography. ITCC review. Israel, n. 45, p. 28-36, jan. 1983.

UNITED STATES OF AMERICA. Department of Housing and Urban Development. Planning new towns: national reports of the U.S. and the U.S.S.R. Washington: Department of Housing and Urban Development, 1981.

UNIVERSIDADE DE BRASÍLIA (UNB). Rodovias como fator de desenvolvimento do processo de urbanização da região Centro-Oeste do Brasil. Brasília: Publicação do autor, 1972. 
UNWIN, Raymond. La practica del urbanismo: una introducción al arte de proyectar ciudades y barrios. Barcelona: Gustavo Gili, 1984 (1909).

VADELORGE, Loïc. Des villes sans histoire. Ethnologie française, França, t. 33, n. 1, p. 21-30, jan./mar. 2003.

VALLAT, Colette. Villes neuves de l'Italie fasciste: usage et limites d'un outil de propagande. Histoire urbaine, França, n. 4, p. 161-182, dez. 2001.

VASCONCELOS, Adirson. As cidades-satélites de Brasília. Brasília: Publicação do autor, 1988.

VERMEERSCH, Stéphanie. Le projet socio-urbain des villes nouvelles: expérimentation et obsolescense. Paris: École d'architecture de Paris Val-de-Seine, 2005.

VIEIRA, Jorge de Macedo. Memorial. São Pedro: [s.n.], 15.12.1939.

VIGNARD, Claude. Et si l'on compte de l'expérience des villes nouvelles : la ville nouvelle de l'Isle d'Abeau, modèle expérimental de “ville-parc”? Métropolis, França, v. V, n. 41-42, p. 44-51, nov./dez. 1979.

VILLAÇA, Flávio. Uma contribuição para a história do planejamento urbano no Brasil. In: DEÁK, Csaba; SCHIFFER, Sueli Ramos (Orgs.). O processo de urbanização no Brasil. São Paulo: Edusp, 1999. Cap. 6, p. 169-243.

VOLDMAN, Danièle (Dir.). Les origines des villes nouvelles de la región parisienne (1919-1969). Cahiers de l'istitut d'histoire du temps présent, França, n. 17, dez. 1990. WADE, Mbaye Thioune. Mémoire sur la politique d'urbanisation au Sénégal et la création des villes nouvelles. Dacar: Direction de l’Urbanisme et de l’Habitat, 1973.

WALKER, Derek (Org.). New towns. Architectural Design. Reino Unido, v. 64, n. 9-10, p. 6-96, out. 1994. 
WARMOES, Isabelle; SANGER, Victoria (Dir.). Vauban, bâtisseur du Roi-Soleil. Paris: Somogy éditions d'art / Cité de l'architecture e du patrimonie / Musée des Plans-reliefs, 2007.

WARNIER, Bertrand. Architecture et urbanisme. Administration, França, n. 141, p. 27-49, out. 1988.

WAWRZYNSKI, Jack. Nowe Tychy: an assessment of a polish new town. Planning outlook, Reino Unido, v. 29, n. 1, p. 34-38, 1986.

WEINER, Howard R. Israel's new towns: a Mediterranean perspective. Ekistics. Grécia, n. 290, p. 393-400, set./out. 1981.

WERMES, Anne. L'envol touristique des villes nouvelles. Espaces loisirs tourisme environnement, França, n. 108, p. 21-23, fev./mar. 1991.

WILHEIM, Jorge. Urbanismo no desenvolvimento. Rio de Janeiro: Saga, 1969.

YOUNGMAN, Peter. New towns 1945-1955. Landscape design, Reino Unido, n. 275, p. 21-22, nov. 1998.

ZELLER, Olivier. La ville moderne: évolutions et nouveautés. In: PINOL, Jean-Luc (Dir.) Histoire de l'Europe urbaine, t. 1. De l'antiquité au XVIIIe siècle. Gênese des villes européennes. Paris: Editions du Seuil, 2003, p. 649-676. 
Este livro foi composto em UnB Pro e Liberation Serif, e impresso no sistema offset, sobre papel offset $75 \mathrm{~g} / \mathrm{m}^{2}$, com capa em papel-cartão supremo $250 \mathrm{~g} / \mathrm{m}^{2}$. 